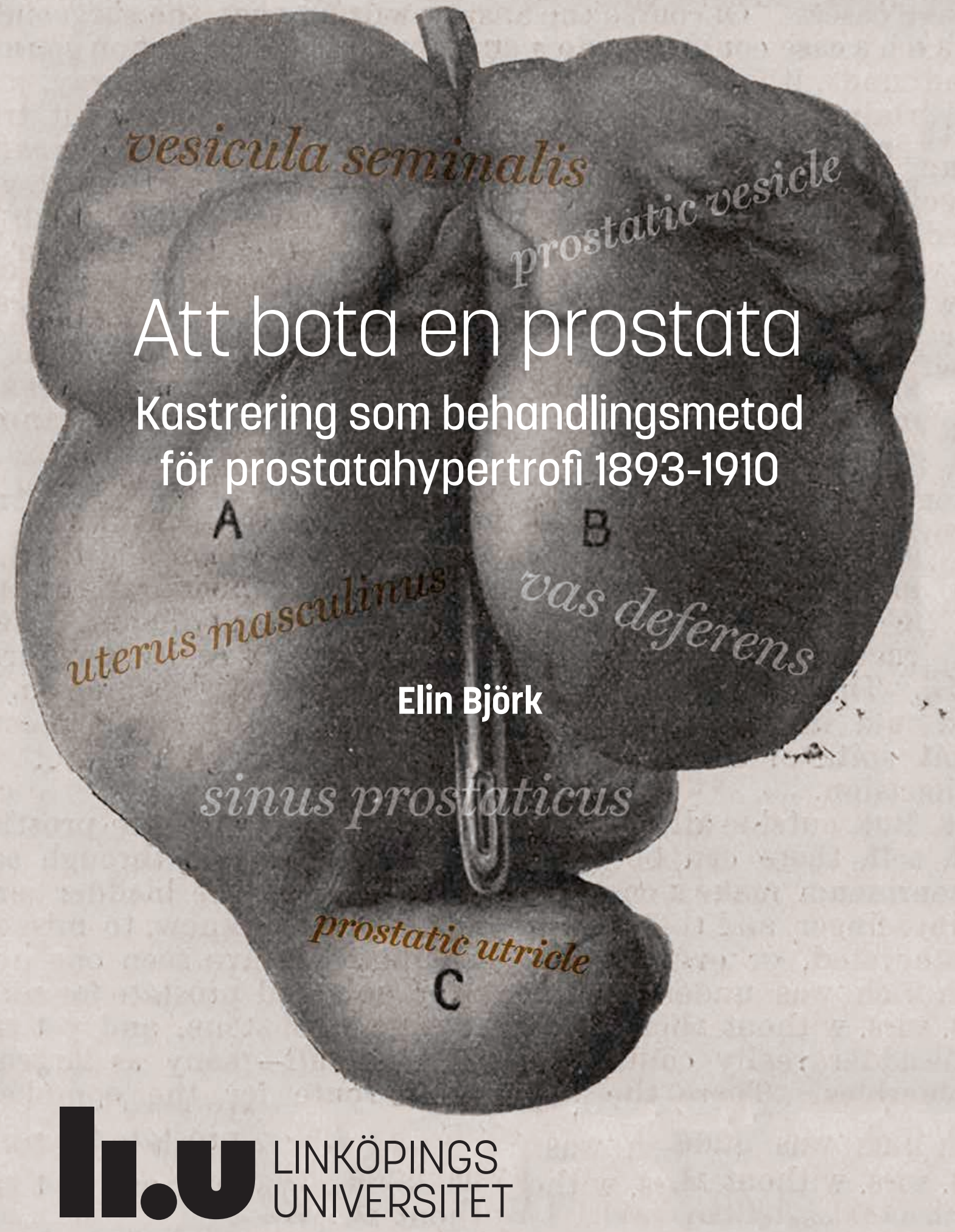




\section{Att bota en prostata Kastrering som behandlingsmetod för prostatahypertrofi 1893-1910}

\section{Elin Björk}

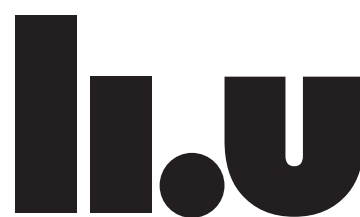

LINKÖPINGS UNIVERSITET

Linköping Studies in Arts and Sciences No. 774

Filosofiska fakulteten

Linköping 2019 
Linköping Studies in Arts and Sciences • No. 774

Vid Filosofiska fakulteten vid Linköpings universitet bedrivs forskning och ges forskarutbildning med utgångspunkt från breda problemområden.

Forskningen är organiserad i mångvetenskapliga forskningsmiljöer och forskarutbildningen huvudsakligen i forskarskolor. Gemensamt ger de ut serien Linköping Studies in Arts and Sciences. Denna avhandling kommer från Teknik och social förändring vid Institutionen för TEMA

Distribueras av:

Institutionen för TEMA Teknik och social förändring Linköpings universitet

58183 Linköping

Elin Björk

Att bota en prostata

Kastrering som behandlingsmetod för prostatahypertrofi 1893-1910

Upplaga 1:1

ISBN 978-91-7685-001-5

ISSN 0282-9800

(C) Elin Björk

Institutionen för TEMA Teknik och social förändring 2019

Framsida: Originalbilden är från Peter Johnston Freyers artikel "A Clinical Lecture On A Fifth Series of Cases of Total Extirpation of The Prostate For Radical Cure of Enlargement of That Organ", The British Medical Journal, vol. 1, nr. 2207, apr. 18, 1903, s. 893.

Formgivning av Tomas Hägg.

Tryckeri: Liu-Tryck, Linköping 2019 
Till min familj 

"Det finns inte så mycket att veta om prostatan, det är en ganska menlös körtel"

Albin Björk, M.D. 2014-10-29 



\section{Innehållsförteckning}

\section{FÖRORD}

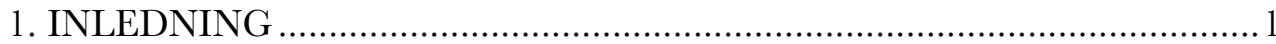

2. SYFTE OCH FRÅGESTÄLLNINGAR ……............................................

3. TEORETISKA OCH METODOLOGISKA UTGÅNGSPUNKTER........7

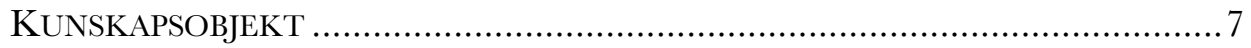

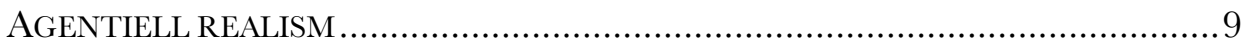

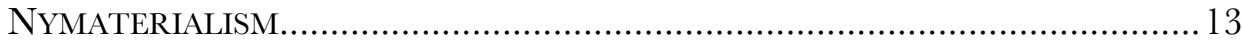

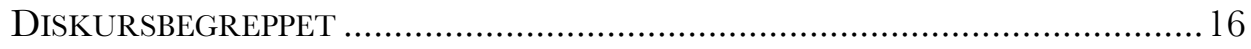

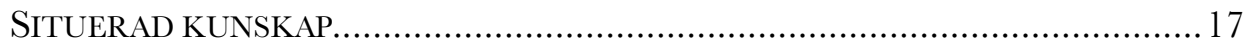

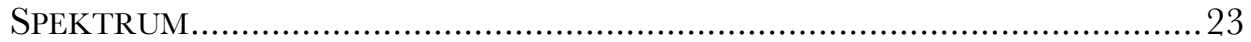

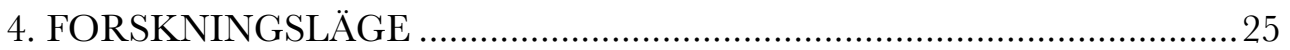

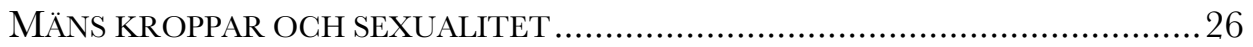

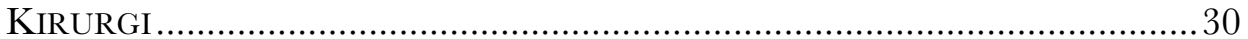

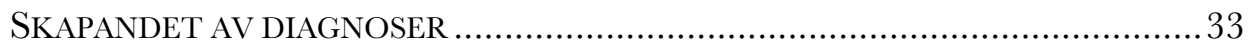

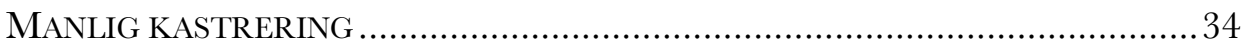

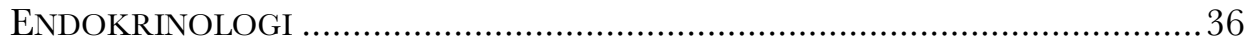

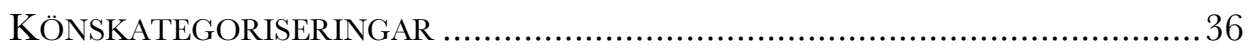

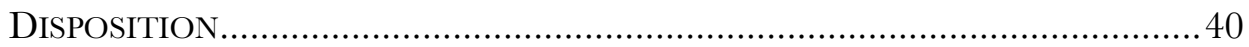

5. PROSTATAN, PROSTATAHYPERTROFI OGH DESS ETIOLOGI....43

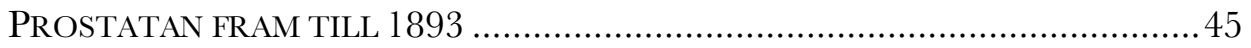

Prostatan frän 1500-talet till mitten av 1800-talet...............................................4 4

Prostatan frän 1800-talets mitt fram till 1890-talet ..............................................52

PROSTATAN UNDER SENARE DELEN AV 1890-TALET .....................................58

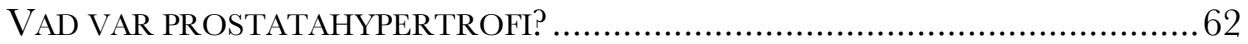




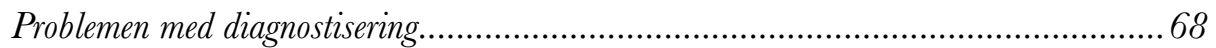

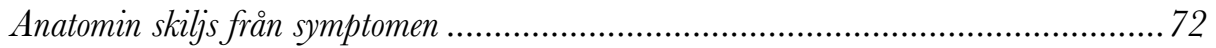

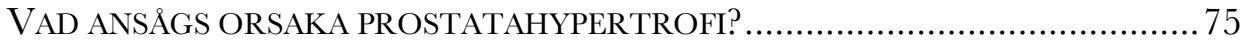

De olika hypoteserna om prostatahypertrofins orsaker ............................................... 78

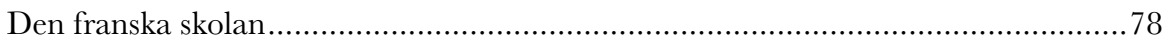

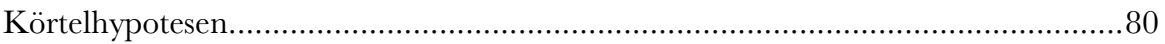

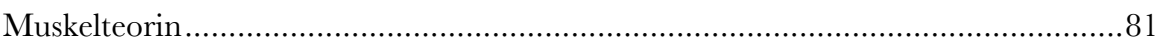

Andra spekulationer kring orsakerna................................................................... 82

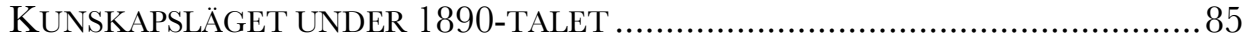

6. BEHANDLINGSMETODER FÖR PROSTATAHYPERTROFI I

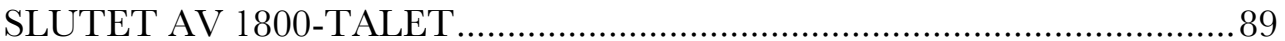

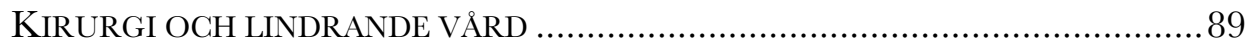

LANSERINGEN OCH MOTTAGANDET AV KASTRERING SOM

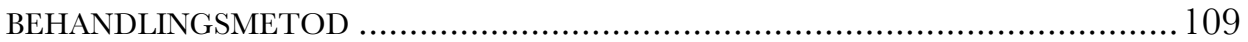

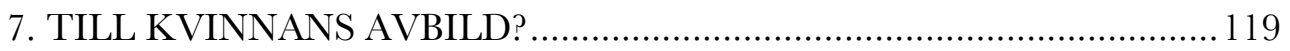

ANALOGIN MELLAN UTERUS OCH PROSTATA .............................................. 122

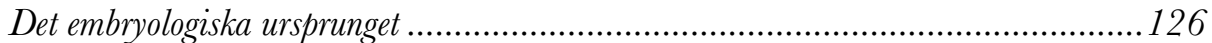

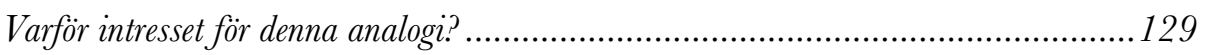

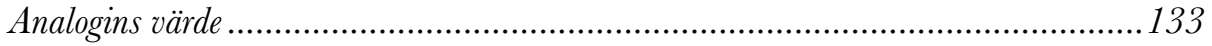

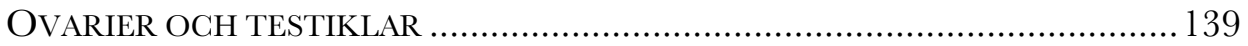

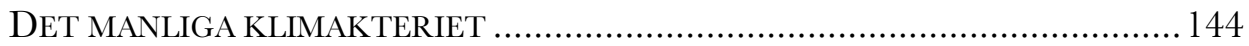

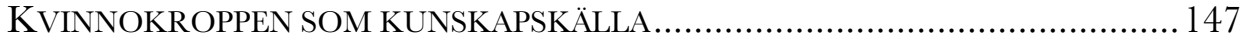

8. PROSTATAN HOS AVVIKANDE MÄN …......................................... 151

ATT KATEGORISERA AVVIKANDE KROPPAR ….......................................... 152

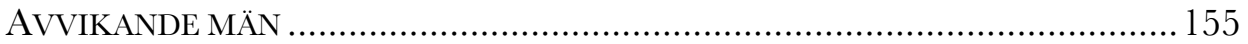

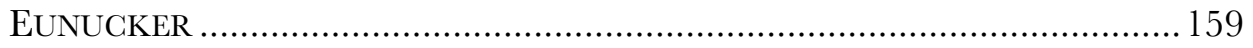

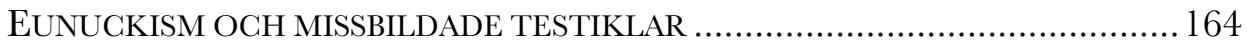

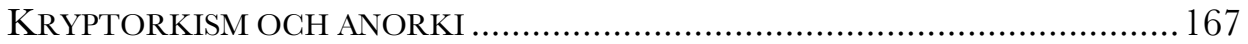




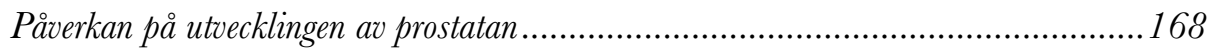

Påverkan på kroppen under puberteten .............................................................. 170

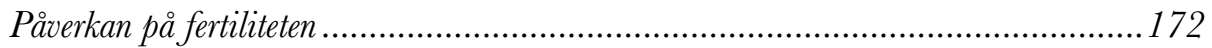

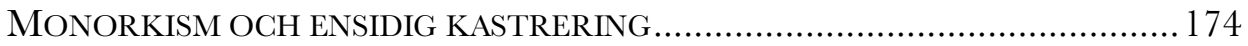

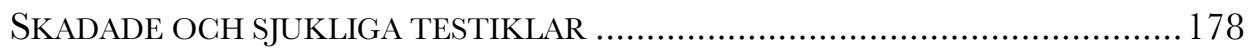

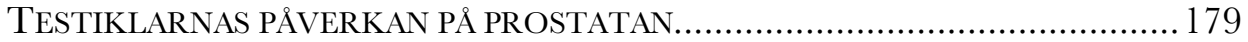

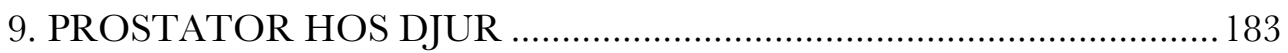

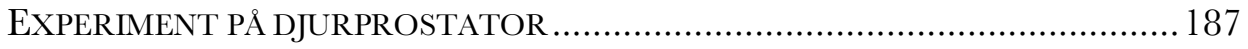

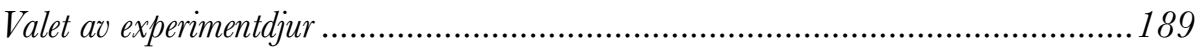

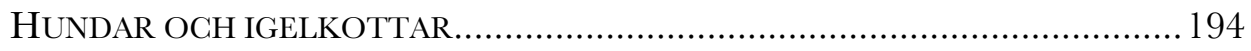

Experimentens omfattning ……...................................................................... 197

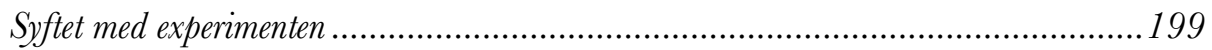

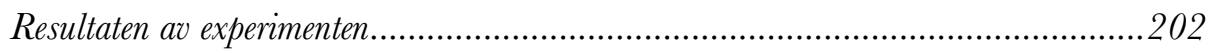

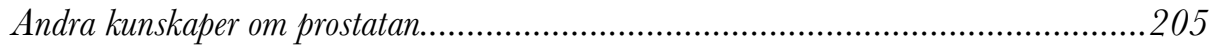

DJUREXPERIMENTENS BETYDELSE FÖR KASTRERING SOM BEHANDLINGS -

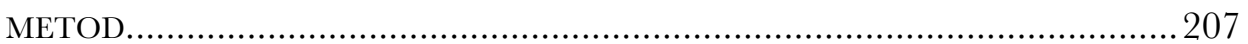

10. KASTRERING AV KVINNOR OGH MÄN.......................................213

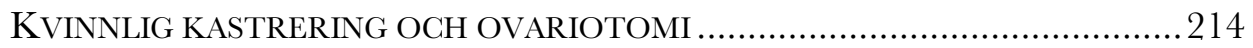

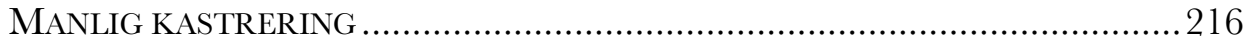

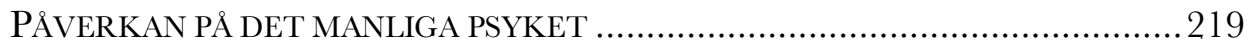

FÖRSÖKEN ATT FÅ BUKT MED DE NEGATIVA PSYKISKA EFFEKTERNA ........... 225

KÖNSKÖRTLARNAS PÅVERKAN PÅ DET MANLIGA OCH KVINNLIGA PSYKET. 230

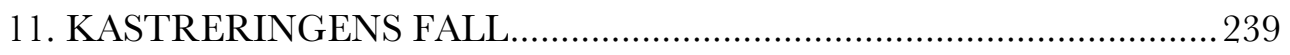

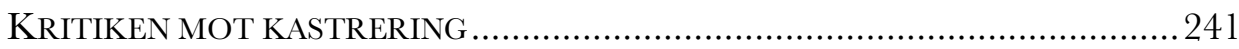

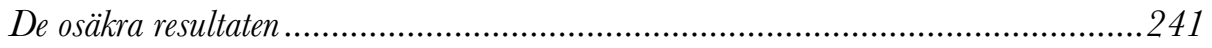

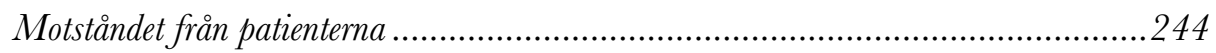

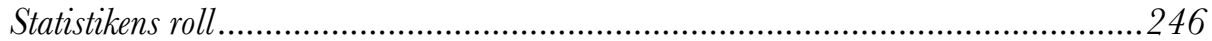

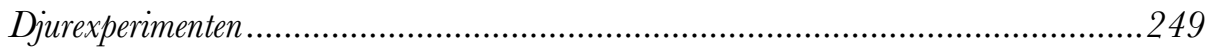




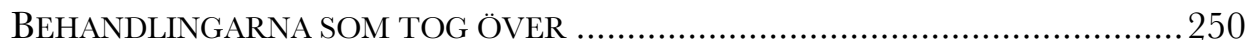

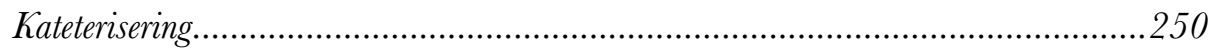

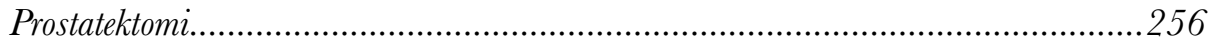

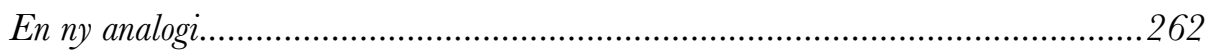

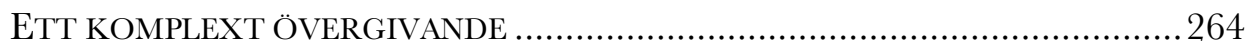

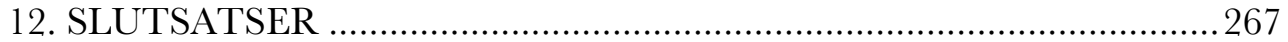

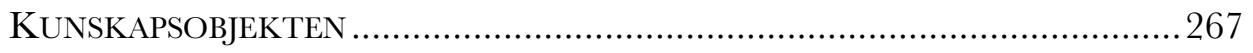

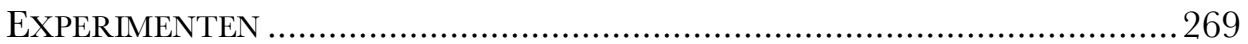

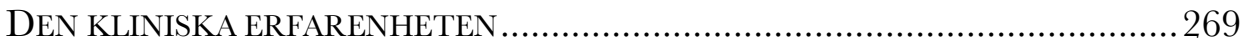

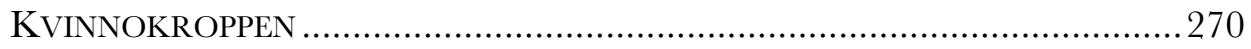

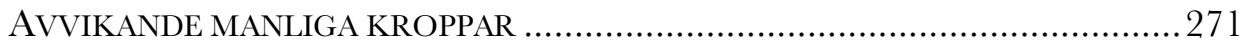

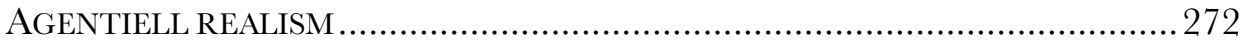

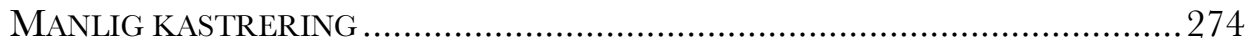

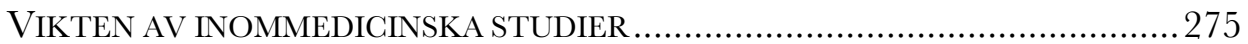

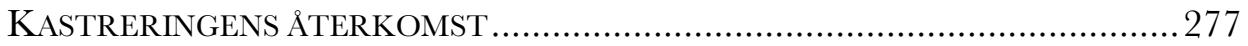

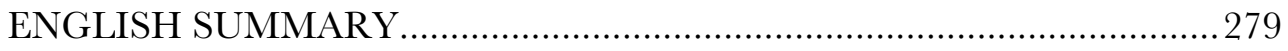

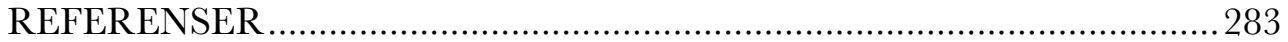

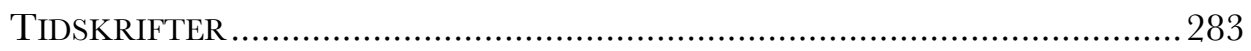

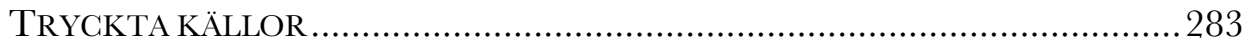

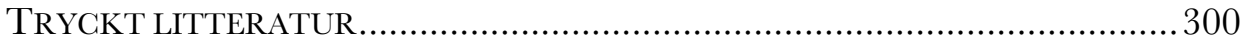

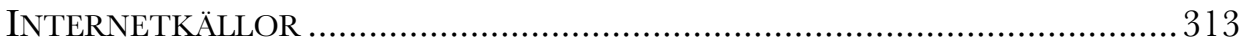




\section{Förord}

Mycket har skrivits om hur det är att skriva en avhandling men trots det finns det något svårt med att sätta ord på tacksamhet. Det känns blekt när orden väl skrivs på pappret. Om det är något som skrivits om att skriva en avhandling så är det att det inte är något man gör själv. När det är dags att säga tack kommer omedelbart rädslan att någon ska glömmas bort. Därför ber jag i förväg om ursäkt om någon känner sig glömd. Du kan trösta dig med att jag säkert kom ihåg dig precis när jag lämnat in till tryck.

Först och främst vill jag tacka mina handledare, Ericka Johnson och Maria Björkman, både för möjligheten att få doktorera och för allt stöd under vägen. Det har betytt oerhört mycket för mig att ni har trott på mig hela vägen, och jag har lämnat varje handledning med en positiv känsla och tanken att jag faktiskt kan slutföra avhandlingsprojektet. Tack, Ericka, för inspiration och uppmuntran att utforska andra teoretiska vägar. När jag nu ser tillbaka är jag imponerad över hur skickligt och varsamt du guidat mig att skriva en mycket mer teoretisk analys än vad jag trodde att jag skulle göra. Tack, Maria, för att du så osvikligt utgjort det stöd som behövdes för att jag skulle kunna genomföra det här projektet som historiker. Jag vill också tacka för korrläsning, korrläsning, korrläsning; du har läst min avhandling mer än någon människa borde behöva göra. Och jag vill rikta ett tack till er båda för stödet under slutspurten då vissa mail bara bestått av meningar som "Elin, ta det lugnt, andas. Du fixar det här." Det har varit mycket välbehövligt.

Denna avhandling har skrivits inom ramen för projektet "Det ständiga gisslet. Diskursiva konturer av den åldrande prostatan” (Dnr 2013-8048) finansierat av Vetenskapsrådet. Detta innebär att jag inte varit ensam i min forskning om prostatan. Jag vill därför även tacka de övriga i "prostatagruppen”, 
förutom mina handledare: Jelmer Brüggemann, Jenny Gleisner, Carina Danemalm Jägervall, Sonja Jerak-Zuiderent, Alma Persson och Oscar Javier Maldonado för trevliga prostataluncher och utflykter till urologikliniker $\mathrm{OCH}$ ANNAT SKOJ.

När det var dags för 60 procentseminarium gjorde Daniel Nordmark ett fantastiskt jobb med att plocka isär hela mitt manus och visa vad jag faktiskt skrev eller kunde skriva om. Tack även Boel Berner och Martin Hultman för läsning och värdefulla kommentarer! Anna Tunlid var opponent på mitt slutseminarium. Tack för en mycket noggrann genomgång av mitt manus och god hjälp för att komma vidare! Tack också till övriga i läsgruppen: Maja Bondestam, Jonas Anselm och Malin Thor Tureby.

TEMA T har varit en mycket bra miljö att skriva en avhandling i, framförallt eftersom det finns så många tillfällen att få stöd, hjälp och uppmuntran från kollegor. Inte minst vill jag särskilt tacka seminariegruppen P6: Kropp, Kunskap, Subjektivitet, som läste och kommenterade mina tidiga utkast, och Kristin Zeiler min närmaste chef, för stöd och hjälp.

Miljön på TEMA innebär att man som doktorand ingår i en större doktorandgrupp. Tack till er alla! Mina närmaste doktorandkollegor förtjänar ett extra tack: Darcy Parks, som alltid varit mer än hjälpsam när jag gett upp på att någonsin förstå de administrativa systemen; Johan Niskanen, som tålmodigt lyssnat när jag suttit i hans soffa och orerat om än det ena än det andra; Ivanche Dimitrievski, som fyllt vårt kontor med växter och alltid gett mig en kram när jag kommit till jobbet; Fredrik Backman, allt blev lite tystare och tråkigare efter att du disputerat. Ni har alla fyra gjort den här tiden så mycket lättare och roligare. Tack!

Jag vill dessutom tacka Jeffrey Christensen, för dans, teori, enhörningar och vänskap, och David Moats, för arbetssällskap på diverse fik och vänskap. Tack också till doktoranderna på TEMA Barn, Emilia Stridh, Emilia Zotevska, Daniel Gustafsson, Yelyzaveta Hrechaniuk, Sarah Mitchell och Peter Skagius, som blivit lite som en extra doktorandgrupp jag fătt vara med i. På idéhistoriska 
institutionen i Uppsala var jag gästdoktorand under våren 2016. Stort tack till alla kollegor där som tog emot mig!

Förutom alla kollegor har ett antal andra personer varit viktiga för arbetet med avhandlingen. Jag vill tacka två vänner från tiden som historiestudent i Linköping: Gustaf Johansson, som både fick mig att söka doktorandtjänsten och som stöttat på ett ovärderligt sätt under hela vägen, och Alexander Engström, vars skratt och värme alltid varit upplyftande. I och med min disputation är pakten uppfylld. Jag vill också tacka min faster, Lotta, som ryckte in i slutskedet med erfarenhet och goda råd. Det finns helt klart fördelar med att inte vara den första som disputerar i släkten!

Sist men absolut inte minst vill jag tacka min familj. Om det är något jag lärt mig under arbetet med avhandlingen så är det hur mycket min familj betyder för mig. Utan ert stöd hade det aldrig blivit en avhandling. Tack till min bror, Albin, som förvisso inte hade så uppmuntrande ord att säga om prostatan inledningsvis, men som vägt upp för det hundra gånger om med medicinsk expertis, stöd och hjälp. Det har dessutom varit roligt att följas åt som doktorander inom mycket olika fält. Tack till min syster, Stina, med familj. Ni har varit en oas att fly till när jag behövt perspektiv på livet och avhandlingen. Det är en ynnest att ha ett syskon som doktorerar samtidigt, men det är det också att ha ett syskon som inte alls håller på med sådant.

Till slut vill jag tacka mina föräldrar. Och här kommer jag tillbaka till vad jag skrev i inledningen, för hur tackar man egentligen för något som inte låter sig uttryckas i ord? Jag som ofta har svårt att vara tyst kan bara hitta ett ord för allt ni gjort för mig under de här åren: Tack.

Linköping, oktober 2019

Elin Björk 


\section{Inledning}

Among the miseries which make long life a burden to its possessor there are none greater than those resulting from an enlarged prostate. The constant pain, the unrest, the ever present desire to pass urine, the inability to do this, the sleep-disturbed nights, and the frequent need for catheterism, cause a concentration of wretchedness such, as makes strong, clear-minded sensible men long for death. ${ }^{l}$

Roderick Maclaren vid British Medical Associations årsmöte i Carlisle i juli 1896.

År 1893 föreslogs kastrering som en ny behandlingsmetod för att bota prostatahypertrofi. Prostatan, som normalt sett borde vara stor som en valnöt, kunde vid detta tillstånd bli stor som en apelsin, vilket för vissa patienter vållade smärta och urineringsproblem. Den mest använda behandlingsmetoden var att tömma blåsan med ett rörformigt instrument, en kateter, vilket i sin tur kunde ge smärtsamma och livsfarliga infektioner i form av urinvägsinfektioner, njurbäckeninflammationer, uremi (urinförgiftning) och sepsis (blodförgiftning). Andra metoder för att behandla prostatahypertrofi var olika former av lindrande vård eller försök att kirurgiskt avlägsna delar av den förstorade prostatan för att på längre sikt bota eller i alla fall lindra patienternas besvär. Nu föreslogs istället en snabb och enkel operation som skulle kunna bota patienterna helt och bespara dem år av lidande och i vissa fall till och med rädda dem från döden. I en situation där olika former av bukkirurgi hade en dödlighet på upp emot 40 procent

\footnotetext{
${ }^{1}$ Roderick Maclaren, "Address In Surgery. On Preventive Surgery", The British Medical fournal, vol. 2, nr. 1857, aug. 1, 1896, s. 261.
} 
framstod ett så icke invasivt och redan etablerat kirurgiskt ingrepp som en mycket löftesrik behandling.

En livlig debatt utbröt genast i olika medicinska tidskrifter. I avdelningen "Correspondence" i The British Medical Fournal publicerade under de första åren av den period jag studerat inte bara en utan ofta flera läkare i varje nummer kortare kommentarer om artiklar i ämnet under rubriker som "Castration in Enlargement of the Prostate". ${ }^{2}$ Men hur kom det sig att kastrering överhuvudtaget föreslogs som behandlingsmetod? Vad i den medicinska kunskapssynen var det som gjorde att behandlingsmetoden kunde föreslås och få ett genomslag just vid denna tid och under några år framöver? Och vad var det som gjorde att läkare senare slutade kastrera för att behandla prostatahypertrofi?

I den här avhandlingen undersöker jag debatten om och beskrivningarna av praktiken kring kastrering för prostatahypertrofi under perioden 1893-1910. I fokus står hur den manliga prostatan skapades som ett kunskapsobjekt och hur kunskapsproduktionen kring manlig kastrering som behandlingsmetod såg ut inom medicinen.

Godartad prostataförstoring kallas den sjukdom med liknande symptom som drabbar många män även idag. Sjukdomen är inte längre livshotande på samma sätt som runt sekelskiftet 1900, men den vållar fortfarande smärta och obehag för

${ }^{2}$ Se till exempel Reginald Harrison, "Castration in Enlargement of the prostate", The British Medical fournal, vol. 2, nr. 1708, sep. 23, 1893, s. 708 - 709; James MacMunn, "Castration in Enlargement of the prostate", The British Medical Fournal, vol. 2, nr. 1708, sep. 23, 1893, s. 708 - 709; Charles Mansell Moullin, "Castration in Enlargement of the Prostate", The British Medical Fournal, vol. 2, nr. 1709, sep. 30, 1893b, s. 765; George Buckston Browne, "Castration for Prostatic Hypertrophy", The British Medical Fournal, vol. 1, nr. 1776, jan. 12, 1895, s. 110; Charles Mansell Moullin, "Castration for Prostatic Hypertrophy", The British Medical fournal, vol. 1, nr. 1776, jan. 12, 1895a, s. 110; Charles E. Jennings, "Castration for Prostatic Hypertrophy", The British Medical fournal, vol.1, nr. 1777, jan. 19, 1895, s. 171; Charles Mansell Moullin, "Castration for Prostatic Hypertrophy", The British Medical fournal, vol.1, nr. 1777, jan. 19, 1895b, s. 171. 
många. Idag finns behandlingar som liknar dem runt sekelskiftet, som kirurgi, men även nyare sorters behandlingar. Prostata-hypertrofins orsak anses idag vara tillväxt av godartade tumörer, adenom, som består av körtelvävnad och glatt muskulatur. ${ }^{3}$ Genom att följa debatten om kastrering kring sekelskiftet kan jag spåra dessa behandlingar och dagens syn på prostatahypertrofi tillbaka till det sena 1800-talet och de idéer och hypoteser som läkare och kirurger presenterade då. Denna avhandling är en tidsmässigt kort, men djupgående, studie av prostatahypertrofins historia och den manliga kastreringens del i denna.

${ }^{3}$ Robert C. Langlan, "Benign Prostate Hyperplasia", Primary Care: Clinics in Office Practice, vol. 46, nr. 2, juni 2019, s. 223. 


\section{Syfte och frågeställningar}

Denna avhandling handlar om kunskapsproduktion och skapandet av kunskapsobjekt inom svensk, norsk och angloamerikansk medicin kring sekelskiftet 1900, med utgångspunkt i diskussionen av och publikationerna om den kortlivade behandlingsmetoden kastrering för prostatahypertrofi. Studiens skärningspunkt är intra-aktionen (se mer nedan) mellan teori, forskning och klinisk erfarenhet vid produktionen av medicinsk kunskap och kunskapsobjekt. För eftervärlden kan metoden framstå som oväntad och radikal, men i sitt sammanhang var den ett mycket tydligt uttryck för hur olika delar av medicinen samverkade för att producera och legitimera kunskap. Genom en närstudie av den kunskap man vid denna tid hade om kastrering, den teoretiska diskussionen om kastrering som en behandling vid prostatahypertrofi samt de kliniska erfarenheterna av behandlingsmetoden har jag studerat hur medicinsk kunskap kunde produceras i praktiken kring sekelskiftet 1900.

Övergripande frågor i avhandlingen är hur prostatan skapades som ett vetenskapligt kunskapsobjekt som kunde bli föremål för studier och behandling samt vilka kunskapsproducerande processer som låg bakom att kastrering kunde föreslås som en behandling vid prostatahypertrofi. Därtill diskuterar jag frågor som: Vilken roll spelade icke-manliga, avvikande manliga och icke-mänskliga kroppar för produktionen av kunskap kring prostatahypertrofi och kastrering? Vilka kliniska erfarenheter gjordes och hur kom dessa att påverka, legitimera och avlegitimera behandlingen? Och vad var det som gjorde att kastrering under 1900-talets första decennium övergavs till förmån för andra behandlingsmetoder? 


\section{Teoretiska och metodologiska utgångspunkter}

Förutom att studera produktionen av ett kunskapsobjekt, prostatan, diskuterar jag hur kunskapsproduktionen kring detta och andra objekt gick till inom medicinen under sent 1800- och tidigt 1900-tal. Min analys fokuserar bland annat på hur de fysiska avgränsningarna av körteln gjordes och hur den tillskrevs vissa egenskaper, samt hur dessa fysiska avgränsningar och tillskrivna egenskaper påverkade hur sjukdomen prostatahypertrofi beskrevs, förstods och behandlades. Jag kommer även att beröra skapandet av testiklarna som ett kunskapsobjekt och hur förståelsen och beskrivningen av dessa körtlar påverkade prostatabehandlingar och förståelsen av prostatan och prostatahypertrofi som sjukdom.

\section{Kunskapsobjekt}

En forskare som har intresserat sig för skapandet av kunskapsobjekt är vetenskapshistorikern Theodore Arabatzis. Han menar att tillkomsten av vetenskapliga objekt eller kunskapsobjekt måste undersökas på mer än ett sätt eftersom de både uppstår och försvinner och förändras över tid, dessutom på olika sätt. Han ställer därför en rad frågor:

How does a new scientific object appear (or pass away)? What accounts for its birth (or death)? What exactly comes into (or out of) being in such cases? Furthermore, what happens after the emergence of a scientific object? Does it evolve over time and in what ways? ${ }^{4}$

4 Theodore Arabatzis, "On the Historicity of Scientific Objects", Erkenn, vol. 75, 2011, s. 378. 
Dessa frågor kräver enligt Azarbatzis att vi tar hänsyn till det han kallar "the career of scientific objects". ${ }^{5}$ Denna delar han upp i tre delar, som inte ska ses som avskilda från varandra utan att de interagerar med varandra, och han beskriver dem på följade sätt:

first, their individuation - the boundaries that carve out an object out of a larger domain; second, their representation - their beings objects of theoretical discourse and experimental modeling; and, third, their observable or experimental manifestations - their being objects of observational or experimental traditions. ${ }^{6}$

Han försöker dock inte ge några mer generella svar på de frågor han stället kring vetenskapliga objekts tillblivelse. Istället menar han att vetenskapens rika och varierade ontologi motsätter sig något sådan. ${ }^{7}$ Samtidigt menar han att "[o]ur knowledge of an object may change without affecting the theoretical criteria or the experimental techniques we use to individuate it". ${ }^{8}$ Arabatzis skiljer mellan ett antal olika sorters vetenskapliga objekt, men han betonar att gränserna kan vara oklara och föränderliga och att värdet i uppdelningarna inte ligger i förekomsten av tydliga gränser. "Rather, it lies in indicating that the questions regarding the birth and historicity of scientific objects admit different answers depending on the particular kind of scientific objects we are dealing with". ${ }^{9} \mathrm{Jag}$ återkommer nedan till hur jag definierar och ser på kunskapsobjekt.

De teoretiska och metodologiska utgångspunkterna för denna avhandling har jag hämtat från framför allt den nymaterialistiska feministiska teoribildningen, i huvudsak den feministiska teoretikern Karen Barads agentiella realism. Genom att utgå från Barad kan jag besvara de frågor Arabatzis ställer kring vetenskapliga

\footnotetext{
${ }^{5}$ Arabatzis 2011, s. 378.

${ }^{6}$ Ibid.

${ }^{7}$ Ibid.

${ }^{8}$ Ibid, s. 384.

${ }^{9}$ Ibid, s. 381.
} 
objekt eller kunskapsobjekts historia: individuation, skapande och försvinnande. Med hjälp av den agentiella realismen kan jag studera kunskapsobjekts produktion utan att reducera förklaringen till regler som gäller för ett enda objekt. Jag behöver inte heller skilja mellan olika sorters vetenskapliga objekt eftersom den agentiella realismen förklarar skapandet av dessa objektkategorier på samma sätt. Utifrån Barad går det inte heller att säga att vår kunskap om kunskapsobjektet kan förändras utan att teoretiska kriterier eller experimentella tekniker förändras. Enligt Barad sker denna förändring i det ögonblick som kunskapen förändras, även om den vetenskapliga praktiken utåt sett förefaller vara densamma. ${ }^{10}$

\section{Agentiell realism}

Den agentiella realismen är en onto-epistemologisk teori, vilket innebär att den försöker förklara både hur världen är beskaffad, hur den kommer till och hur vi kan nå kunskap om den. Den ursprungliga materialismen utgick från att världen består av materia som existerar oberoende av människor och deras betraktelse av denna. Inom den feministiska nymaterialismen förutsätts en intra-aktion mellan det materiella och det diskursiva. Barad menar att världen består av det hon kallar fenomen som uppstår i intra-aktion mellan subjekt, objekt och apparater. ${ }^{11}$ Det viktiga här är att det är en intra-aktion och inte inter-aktion. Det är inte en interaktion mellan a priori distinkta entiteter utan istället skapas allt det som identifieras som subjekt och objekt i materiellt-diskursiva intra-aktioner. "Intra" betyder här "ömsesidig påverkan" mellan allt det som utgör världen. I denna intra-aktion har objekt och icke-mänskliga subjekt agens. De påverkar, förändrar och skapar

\footnotetext{
${ }^{10}$ För ytterligare historiska studier av vetenskapliga object se Lorraine Daston, (red.), Biographies of scientific objects, University of Chicago Press, Chicago, Ill., 2000.

${ }^{11}$ Karen Michelle Barad, Meeting the Universe Halfway: Quantum Physics and the Entanglement of Matter and Meaning, Duke University Press, Durham, N.C., 2007, s. 197.
} 
subjekten i lika hög grad som subjekten påverkar, förändrar och skapar dem. ${ }^{12}$ Till exempel är det inte en inter-aktion mellan en a priori existerande läkare och prostata, utan läkaren och prostatan skapas i en intra-aktion i den situation där de möts.

Apparater är i den agentiella realismen teknologier som används för att nå kunskap om världen, det vill säga i det här sammanhanget såväl mikroskop, katetrar och cystoskop (en typ av endoskop - instrument för att titta in i kroppen - avsett för urinröret och urinblåsan) som ögon och fingrar. Apparater är allt det som medierar mellan subjektet, läkaren och objektet, prostatan. Barad menar att även dessa skapas i intra-aktion med subjektet och det materiella objektet. ${ }^{13}$ Apparater som är konstruerade av människor, exempelvis medicinska instrument, skapas i intra-aktion med de rådande materiella förutsättningarna och de objekt som studeras. Detta innebär både möjligheter och begränsningar i hur apparater kan se ut och fungera. Till exempel behöver mikroskopet en lins som kan förstora och det upplysta cystoskopet behöver elektricitet. När dessa apparater väl konstruerats kommer de att ingå i skapandet av andra fenomen genom intraaktion med subjekt och objekt. På detta sätt skapas och omskapas hela tiden fenomen. Apparater är inte endast teknologier skapade av eller använda av människor utan också gränsdragande praktiker. De utgör specifika materiella konfigurationer av världen som när de används får betydelse för hur vi uppfattar den. ${ }^{14}$ Och fenomen ska inte endast ses som produkten av laboratorieexperiment och liknande, utan som intra-aktioner vilka även sker i världen utanför. ${ }^{15}$

Barad menar att vad som definieras som objekt, subjekt eller apparat skapas intra-aktivt genom specifika praktiker. ${ }^{16}$ När läkaren tittar i mikroskopet och ser

\footnotetext{
12 Barad 2007, s. 208.

13 Ibid, s. 203.

${ }^{14}$ Ibid, s. 206.

${ }^{15}$ Ibid.

${ }^{16}$ Ibid.
} 
strukturer i prostatavävnad skapas strukturerna i intra-aktion mellan läkaren (subjektet), mikroskopet (apparaten) och prostatan (objektet). På detta sätt skapas och omskapas hela tiden fenomen i en iterativ process. En värld där fenomen inte är utan konstant görs kommer att genomkorsas av otydliga gränser. Allting hänger samman och det är svårt att urskilja distinkta objekt och subjekt. I en enskild intraaktion kan dock vad Barad kallar ett agentiellt snitt avskilja subjektet från objektet. ${ }^{17}$ Barad skriver:

It is through specific agential intra-actions that the boundaries and properties of the "components" of phenomena become determinate and that particular embodied concepts become meaningful. ${ }^{18}$

En sådan specifik intra-aktion skapar vad Barad kallar för ett agentiellt snitt. Detta snitt kan inom fenomenet avskilja subjektet från objektet. På detta sätt skapas en lokal lösning inom fenomenet på det ontologiska problemet med inseparabilitet mellan den som observerar och det observerade. ${ }^{19}$

För att ta ett konkret exempel är det genom ett agentiellt snitt som prostatan skapas som studieobjekt. Själva körteln med sina två eller tre lober, kapseln runtomkring och annan vävnad avgränsas från närliggande delar, som prostatan egentligen är intimt förknippad med: sädesledare, sädesblåsor, urinrör, Cowpers körtlar och så vidare. Alla delar i detta system hänger ihop, ingenting är egentligen skilt från något annat, men genom agentiella snitt delas det upp i mindre delar. Därtill är systemet enligt Barad inte naturligt avskilt från subjektet som studerar det eller de apparater som subjektet använder, utan genom de agentiella snitten avskiljs även subjektet och apparaterna för att skapa ett objekt.

\footnotetext{
${ }^{17}$ Karen Barad, "Posthumanist Performativity: Toward an Understanding of How Matter Comes to Matter", Signs: Fournal of Women in Culture and Society, vol. 28, nr. 3, 2003, s. 815.

${ }^{18}$ Barad 2003, s. 815.

19 Ibid.
} 
Sådana gränsdragningar är nödvändiga för att vi ska kunna vetenskapligt studera världen, men vi bör vara medvetna om att vi gör dem. Agentiella snitt är historiskt situerade, vilket innebär att exempelvis organ och körtlar i kroppen har avgränsats eller identifierats som självständiga objekt på olika sätt under olika perioder. Som historiker är jag intresserad av var dessa snitt har gjorts, varför, hur, och vad de har fått för konsekvenser för kunskapsproduktionen inom medicinen. Hur blev prostatan en prostata? Och vad innefattade begreppet i slutet av 1800-talet?

Realismen i Barads agentiella realism består i att det finns en strävan att finna korrekta beskrivningar av verkligheten. Men det finns inga mänskliga subjekt som kan ställa sig utanför den agentiella verkligheten och beskriva en värld som inte är påverkad eller beroende av människor, eftersom även människor är fenomen. I den process där fenomen blir till eller materialiseras räcker det inte med att säga att något är på ett visst sätt för att det ska vara så. Förklaringar som inte både tar hänsyn till diskursiva och materiella begränsningar kommer inte heller att vara empiriskt adekvata förklaringar, vilket innebär att inte vilka berättelser som helst om världen duger. ${ }^{20}$ Inte heller kommer konstruktionen av eller användandet av specifika instrument i ett laboratorium att producera vilka resultat som helst. ${ }^{21}$ Alla apparater har begränsningar vilket styr den kunskap som kan produceras genom dessa.

Inspirerad av Barad definierar jag därför begreppet kunskapsobjekt på följande sätt: ett kunskapsobjekt är ett objekt som avskilts från subjekt och apparater för att vara möjligt att studera vetenskapligt. Detta avskiljande vilket sker genom agentiella snitt är inte på förväg förutbestämt utan historiskt situerat och kan därför skifta mellan olika tidsperioder.

\footnotetext{
${ }^{20}$ Barad 2007, s. $206-207$.

${ }^{21}$ Ibid, s. 211.
} 


\section{Nymaterialism}

I min avhandling utgår jag från den nymaterialistiska uppfattningen att den materiella världen, kroppen och naturen, för med sig begränsningar i beskrivningar av och förutsättningar för hur vi kan förstå människorna och det samhälle vi lever och har levt i. ${ }^{22}$ Det gäller även vår förståelse för och kunskap om organ och sjukdomar. Samtidigt vill jag poängtera att jag inte ger den materiella sidan av den dualistiska uppdelningen "materiell-semiotiskt" företräde eller ser den som mer relevant för den diskursiva analysen eller förståelsen av produktionen av kunskapsobjekt eller kunskap. ${ }^{23}$ Jag strävar efter att uppnå jämvikt mellan det materiella och det semiotiska, eller snarare vill jag utforska det dialektiska förhållandet mellan dem, en utveckling som bland andra genusforskarna Lena Gunnarsson och Caroline Braunmühl efterfrågat inom den nymaterialistiska teoribildningen. ${ }^{24}$ Gunnarsson menar att feminister länge har sett naturen, det materiella, som sin fiende. I och med den poststrukturalistiska vändningen, och dess fokus på sociala konstruktioner, språk och makt, blev det tabu att hävda en koppling mellan biologiskt kön och genus, och ett tidigt feministiskt mål var att avvisa den "naturliga" manliga överhögheten genom att visa att den formats historiskt och är föränderlig. ${ }^{25}$

De nymaterialistiska teorier som har vuxit fram har vitt skilda teoretiska och analytiska inriktningar. Det som förenar dem är en annorlunda syn på naturen än i de poststrukturalistiska teorierna. Naturen (eller det biologiska) är inte längre

\footnotetext{
${ }^{22}$ Lena Gunnarsson, "The naturalistic turn in feminist theory: A Marxist-realist contribution", Feminist Theory, vol. 14, nr. 1, 2013, s. 3 - 19.

${ }^{23}$ Gill Jagger, "The New Materialism and Sexual Difference”, Signs: Fournal of Women in Culture and Society, vol. 40, nr. 2, 2015, s. 339 - 340.

${ }^{24}$ Gunnarsson 2013; Caroline Braunmühl, "Beyond hierarchical oppositions: A feminist critique of Karen Barad's agential realism", Feminist Theory, vol. 19, nr. 2, 2018, s. 223 - 240.

${ }^{25}$ Gunnarsson 2013, s. 3 - 4.
} 
fienden eftersom inte heller naturen ses som fixerad eller statisk. ${ }^{26}$ Gunnarsson uttrycker en förhoppning om att "the naturalistic turn could direct its energies more towards examining more concretely how nature conditions the social". ${ }^{27}$ Gunnarsson och Braunmühl betonar vikten av att problematisera dualismer och uppdelningar som den mellan natur och kultur. ${ }^{28}$ Braunmühl lyfter fram Barad som en teoretiker som "advocates examining how distinctions are generated by apparatuses that intra-actively produce phenomena which they themselves are part of" ${ }^{29}$ Att bara försöka ignorera eller undanröja dualismer och uppdelningar gör inte att de, eller deras effekter i samhället, försvinner. Istället bör vi undersöka vad de gör. Det viktiga att undersöka är hur dualismer och uppdelningar skapar skillnader mellan till exempel kvinnor och män, och om vi därför borde definiera om dem eller sluta använda dem. ${ }^{30}$

Eftersom mitt forskningsmaterial består av text är jag begränsad till att analysera den materiella sidan så som den återges semiotiskt diskursivt. Mitt mål är dock att så långt det är möjligt behandla kroppens beskrivna materiella begränsningar och möjligheter som lika viktiga för produktionen av ett kunskapsobjekt som de semiotiskt diskursiva uppfattningarna av det. Jag gör detta genom att analysera de beskrivna medicinska praktikerna utifrån en semiotisktmateriell diskursiv analys. Denna analys syftar till att förstå den semiotisktmateriella diskursiva praktik där intra-aktionen mellan läkare, patient, medicinsk kunskap, medicinsk praktik, klinisk praktik, experiment och teknik intra-agerar och skapar prostatan som ett kunskapsobjekt som läkarna kunde ha kunskap om, som kunde drabbas av sjukdom och som kunde behandlas. Den syftar även till att förstå på vilka sätt kroppen begränsade vilka tolkningar som var möjliga att göra.

\footnotetext{
${ }^{26}$ Gunnarsson 2013, s. $3-4$.

27 Ibid, s. $17-18$.

${ }^{28}$ Gunnarsson 2013, s. 13 - 14; Braunmühl 2018, s. 224.

${ }^{29}$ Braunmühl 2018, s. 225.

${ }^{30}$ Gunnarsson 2013, s. 13 - 14; Braunmühl 2018, s. 225.
} 
I varje ögonblick finns ett antal möjliga tolkningar, och vilka de är styrs av de materiella förutsättningarna, och dessutom av den språkliga delen av diskursen, vad språkets uppbyggnad och ord medger och vad som kan begripliggöras för dem som deltar i diskursen.

I fallet med prostatan kunde den skapas som kunskapsobjekt på ett flertal sätt utifrån de materiella förutsättningarna, men inte hur som helst. Språkligt skulle man kunnat säga en hel del saker som låg både inom och utanför den rådande diskursen, men rent materiellt gick det inte att få prostatan att vara vad som helst. Den materiella sidan av ett objekt motstår vissa tolkningar och funktioner. Som vi kommer att se kunde tolkningen att prostatan var en muskel och att prostatan var en körtel existera samtidigt diskursivt, men med tiden skulle det materiella objektet motsätta sig den ena tolkningen. Och även om det hävdades att prostatan var det organ som motsvarade livmodern hos kvinnor så var det omöjligt att konstruera prostatan som ett objekt som fungerade som en livmoder. Där gjorde det materiella alltför stort motstånd.

Mot bakgrund av den nymaterialistiska inställningen till det materiellas roll menar Gill Jagger att för att vi ska kunna förstå det materiellas roll i den kulturella konstruktionen av till exempel ett kunskapsobjekt som prostatan så behövs en kombination av förståelser. ${ }^{31}$ För det första behövs kunskap om hur medicinen fungerade under perioden och vad man ansåg sig veta om de materiella objekten, för det andra insikter från samhällsvetenskapliga analyser av vetenskap och hur dessa kan göras, och för det tredje insikter från vetenskapsfilosofin. ${ }^{32}$ Utifrån detta studerar jag hur prostatan som materiellt objekt, periodens medicinska diskursiva förståelse av kroppen och de kliniska och medicinska praktikerna tillsammans skapade prostatan som ett kunskapsobjekt.

\footnotetext{
${ }^{31}$ Jagger 2015, s. 322.

32 Ibid.
} 


\section{Diskursbegreppet}

Materialet för denna studie består till största delen av artiklar publicerade i några av de största svenska, norska och angloamerikanska medicinska tidskrifterna runt sekelskiftet 1900. Min diskursanalys går delvis tillbaka till den ursprungliga betydelsen i Michel Foucaults diskursbegrepp - där praktik är en del av diskursen - men jag tillämpar den materiellt-semiotiska diskursanalys som bland andra Donna Haraway har utvecklat med utgångspunkt i Foucault. Den teoretiska grunden för min analys är därför inte den socialkonstruktivistiska synen som ligger till grund för många former av mer semiotiskt inriktade diskursanalyser utan en nymaterialistisk materiellt-semiotisk diskurs. ${ }^{33}$ Enligt översättaren Mats Rosengren låter sig inte det franska ordet discours utan vidare översättas. Det har betydelser som inte omfattas av exempelvis svenskans "diskurs", till exempel använder Foucault ordet diskurs för "hela den praktik som frambringar en viss typ av yttranden". ${ }^{34}$ Han menar även att Foucualt använder ordet som en generell och teknisk benämning på alla skrivna och yttrade fraser. ${ }^{35}$

När praktik står i fokus för analysen uppstår frågan hur diskurs och praktik skiljer sig åt, eller om de gör det. I sin artikel "On the Alleged Distiction Between Discourse and Praxis" menar Steve Woolgar, professor i teknik- och vetenskapsstudier, att det uppstått en uppdelning mellan språklig diskurs och praktik, som saknas i bland annat det franska diskursbegreppets ursprungliga betydelse. Uppdelningen uppstod enligt Woolgar när de franska

33 Mats Rosengrens kommentarer till Michel Foucault, Diskursens ordning: installationsföreläsning vid Collège de France den 2 december 1970, Brutus Östlings bokförlag Symposion, Stockholm, 1993, s. 57; Donna Jeanne Haraway, Modest_Witness@Second_Millennium.FemaleMan@_Meets_ OncoMouse: feminism and technoscience, Routledge, New York, 1997, s. 218; Marianne Winther Jørgensen \& Louise Phillips, Diskursanalys som teori och metod, Studentlitteratur, Lund, 2000, s. 11.

${ }^{34}$ Foucault 1993, s. 57.

35 Ibid. 
poststrukturalistiska texterna lästes av brittiska forskare som var inspirerade av anglosaxisk empirism. ${ }^{36}$ Enligt den anglosaxiska empirismen beror relevansen av en observation på avståndet mellan objektet och den som observerar, och tillförlitligheten hos en beskrivning är beroende av om den är skriftlig eller muntlig. När det gäller tillförlitlighet är gränsen mellan praktik och diskurs alltså mycket skarp, och det är detta som enligt Woolgar har gett upphov till den påstådda skillnaden mellan vad vetenskapsmän gör och vad de säger att de gör. ${ }^{37}$ Foucaults diskursbegrepp innebär, enligt Woolgar, "a whole concatenation of activities, events, circumstances and objects which together make up a particular wold-view." 38 Hos de brittiska empiristerna blev diskurs istället "a narrow set of empirically observable linguistic activities". ${ }^{39}$

I Woolgars tolkning av Foucaults diskursbegrepp finns det ingen strikt åtskillnad mellan det betecknande och det betecknade, eller mellan observatören och objektet. Det finns även en stark kritik mot att ge mänskliga aktörer företräde. Det finns inte heller någon tydlig skillnad mellan diskurs och praktik. Praktiken kan inte existera utanför diskursen, och att förstå praktiken skiljer sig inte från att förstå diskursen. Istället för att se gränsen mellan tinget och det vi kan säga om tinget som förutbestämt så blir den något vi aktivt skapar. ${ }^{40}$

\section{Situerad kunskap}

Mitt resonemang är som sagt inspirerat av Haraway och liksom de franska poststrukturalistiska filosoferna, som hämtade inspiration till sina diskursanalyser

\footnotetext{
36 Steve Woolgar, "On the Alleged Distinction Between Discourse and Praxis", Social Studies of Science, vol. 16, nr. 2, 1986, s. 310.

37 Woolgar 1986, s. $310-311$.

${ }^{38}$ Ibid, s. 312.

39 Ibid.

${ }^{40}$ Ibid, s. 312, 314.
} 
från strukturalistisk lingvistik, är materiell semiotik inspirerad av lingvistiken. ${ }^{41}$ Vetenskapsatropologen Amade M'Charek menar att "[w]ords do not have an essence by and of themselves but only in relation to one another." ${ }^{42}$ På samma sätt menar hon att man inom den materiella semiotiken anser att saker, objekt, entiteter får mening i sina relationer. ${ }^{43}$ Haraway menar att "discourses are not just 'words'; they are material-semiotic practices through which objects of attention and knowing subjects are both constituted". ${ }^{44}$ Jämfört med Steve Woolgar, som inkluderade praktiker i diskursbegreppet, går Haraway ännu längre: hon inkluderar även icke-människor som både konstituerande av kunskapsobjekt och det vetande subjektet. Men framförallt skiljer sig Woolgar och Haraway åt när det gäller synen på den kunskap om vetenskap som en diskursanalys kan åstadkomma. Woolgar fokuserar på att inkludera observerbara praktiker i diskursen men Haraway vill även rikta uppmärksamheten mot att inte bara är praktiken inkluderad utan den är dessutom situerad, beroende av sin kontext. Den kunskap vi producerar, i det här fallet om vetenskaplig kunskap, är alltid situerad i en viss kontext och på en viss plats, vilket påverkar hur den kommer att se ut. ${ }^{45}$ Kunskapsobjektet inom vetenskap, till exempel prostatan, skapas samtidigt som, och i interaktion med, det vetande subjektet, läkaren i det här fallet. Dessutom kommer de till i interaktion med större strukturella faktorer som medicinens institutioner, klassystem osv. Inom dessa institutioner praktiseras medicin på vissa sätt, med hjälp av vissa teknologiska hjälpmedel och utifrån vissa teoretiska

${ }^{41}$ Woolgar 1986, s 311; Amade M'Charek, "Beyond Fact or Fiction: On the Materiality of Race in Practice”, Cultural Anthropology, vol. 28. nr. 3, 2013, s. 421.

${ }^{42}$ M'Charek 2013, s. 421.

${ }^{43}$ Ibid.

${ }^{44}$ Haraway 1997, s. 218.

${ }^{45}$ Donna Jeanne Haraway, "Situated Knowledges: The Science Question in Feminism and the Privilege of Partial Perspective”, Feminist Studies, vol. 14, nr. 3, hösten, 1988, s. 582 - 583. 
föreställningar. Även dessa påverkar enligt Haraway hur ett kunskapsobjekt konstrueras i en materiellt-semiotisk praktik. ${ }^{46}$

Detta gör det möjligt för mig att analysera det historiska materialets beskrivningar av praktiker inte bara semiotiskt-diskursivt. Det blir då möjligt att ställa och besvara frågor som: Hur skapades prostatan som ett kunskapsobjekt inom medicinen 1890-1910 rent handgripligt? Hur gjorde man? Vilka undersökningar användes, och hur? Vilken medicinsk teknik användes, och hur? Vilka teorier försökte man omsätta i praktiken? Och när och hur motstod kroppar och praktik dessa teoretiska resonemang?

Mitt material består av debattartiklar och kortfattade insändare av läkare som debatterade kastreringen som behandlingsmetod för prostatahypertrofi i The Lancet och British Medical Fournal, samt längre artiklar i exempelvis Annals of Surgery och The Gournal of the American Medical Association. Texterna återger personliga åsikter, beskrivningar av praktiker kring kunskapsproduktion och ibland vad patienter påstås ha sagt om sina upplevelser. Artiklarna i en medicinsk tidskrift vid denna tid skilde sig på flera sätt från moderna medicinska artiklar. För det första tog de många gånger ett mycket större grepp över ett område: en läkare kunde återge såväl detaljerade patientberättelser om undersökningar, operationer och tillfrisknande, som statistiska resonemang om mortaliteten vid kastrering och teorier om vad testiklarna har för uppgift i kroppen. Vissa av dem var mer lika nutida översiktsartiklar, fast de oftast även innehöll en viss läkares egna patientberättelser eller statistiska resultat. Ibland var de författade som artiklar, ibland var de föreläsningar hållna för läkarstudenter eller kollegor i något medicinskt samfund. Det finns även ett stort antal mycket korta debattartiklar som publicerades i ett högt tempo då både The Lancet och The British Medical Fournal kom ut en gång i veckan.

\footnotetext{
${ }^{46}$ Haraway 1997, s. 129.
} 
Att materialet ser ut på detta sätt gör att det går att följa kunskapsproduktionen som debatten såg ut under det att den fördes. Den stora spridningen i innehåll ger också väldigt olika material att analysera. I de korta debattartiklarna är det ofta kortare argument för eller emot olika ståndpunkter eller helt enkelt bara en kort patientberättelse där författaren inte drar några egna slutsatser eller presenterar någon analys eller teoretiska spekulationer. Ett stort antal artiklar publicerades nämligen med syftet att bidra med data om hur många som avled och av vilken orsak, till de större statistiska sammanställningarna. ${ }^{47}$ Artikelmaterialet är inte på något sätt möjligt att använda för en analys av patienternas eller läkarnas upplevelser. Mitt fokus ligger på den kunskapsproducerande praktiken inom medicinen, den kollektiva produktionen av kunskap inom ett forskarsamhälle. Hur argumenterar man för ett visst teoretiskt eller praktiskt perspektiv? Vilka vetenskapliga berättelser accepteras och vilka accepteras inte?

Vad utövarna av medicinsk kunskapsproduktion under den här perioden gjorde, precis som deras nutida kollegor gör, är att berätta en berättelse som ger

${ }^{47}$ Se till exempel William Whites upprop i Annals of Surgery "Effects of Unilateral Castration on the Prostate", vol. 21, 1895c, s. 492, där han uppmuntrade läkare att informera honom om sina resultat kring unilateral, ensidig, kastrering. Samma upprop publicerades även i The British Medical Fourna,l vol. 1, nr. 1783, mar. 2, 1895c, s. 508; Se även Arthur Powell, "Atropy of Prostate After Castration", The British Medical Journal vol. 2, nr. 1716, nov. 18, 1893, s. 1099; Hurry Fenwick, "The Effects of Unilateral Castration on the Prostate", The British Medical fournal vol. 1, nr. 1784, mar. 9, 1895a, s. 529 som var ett direkt svar på Whites uppmaning; P. C. Remondino, "The Effects of Unilateral Castration on the Prostate", The British Medical fournal vol. 1, nr. 1788, apr. 6, 1895, s. 786; H. W. M. Kendall, "Castration in Enlarged Prostate", The British Medical fournal vol. 2, nr. 1813, sep. 28, 1895, s. 779; H. W. Webber, "Orchotomy for Enlarged Prostate", The British Medical Fournal vol. 1, nr. 1833, Feb. 15, 1896, s. 400; H. M. Brownfield, "Castration for Prostatic Hypertrophy", The British Medical Fournal vol. 1, nr. 1837, mar. 14, 1896, s. 657; Frederick Charlton, "A Case of Castration for Prostatic Hypertrophy", The British Medical Fournal vol. 1, nr. 1843, apr. 25, 1896, s. 1031 1032. 
sken av att skrivas från ingenstans, från en fast och objektiv punkt. Haraway menar att inom den objektiva synen på kunskap har seendet förflyttats ut ur kroppen till en plats som är ingenstans och kan därifrån se objektivt på världen. Det är från denna plats som den vite, manlige vetenskapsmannen har kunnat se och kategorisera alla andra grupper och samtidigt själv undgått kategorisering och framstått som könlös, raslös och helt objektiv. ${ }^{48}$ I sin artikel "Situated Knowledges: The Science Question in Feminism and the Privilege of Partial Perspective" diskuterar Haraway situerad kunskap (situated knowledge) mer i detalj. För att komma bort ifrån denna objektiva syn på kunskap, men ändå kunna tala om kunskap som "objektiva fakta", skapar Haraway en feministisk objektivitet som bygger på att all kunskap är situerad. Dessutom menar hon att seendet alltid är förkroppsligat. Det är alltid någon som ser från en viss punkt. Att betrakta världen utifrån, från en objektiv utsiktspunkt, kallar Haraway "gudstricket" eftersom hon menar att det är omöjligt. All kunskap är situerad, slår hon fast. Den påverkas av den kontext där den skapas, i det här fallet av exempelvis strukturella faktorer som medicinens institutioner och samhällets klassystem. Inom dessa institutioner praktiseras medicin av hävd på vissa sätt, med hjälp av vissa tekniska hjälpmedel och utifrån vissa teoretiska föreställningar. ${ }^{49}$

Att situera kunskap och medvetandegöra seendet ger ingen oskyldig doktrin av objektivitet, de som skapar den kunskap som betraktas som objektiv har fortfarande ett ansvar. Men det ger en objektivitet som inte skiljer subjektet från objektet, och detta gör oss ansvariga för vad vi lär oss att se och hur. ${ }^{50}$ Haraway talar primärt om hur feministiska forskare som studerar samtida material kan hantera objektivitetsbegreppet, men hennes tankar är en bra utgångspunkt även för analysen i min avhandling. Läkarna som kommer till tals i materialet

\footnotetext{
${ }^{48}$ Haraway 1988, s. 581.

${ }^{49}$ Ibid, s. $581-583$.

${ }^{50}$ Ibid, s. $583-585$.
} 
diskuterar och handlar till stor del som om gudstricket var möjligt och som om de själva vore objektiva, men i analysen ser jag all kunskap som situerad och lägger stor vikt vid att undersöka hur det kom sig att kunskapen under den här perioden blev konstruerad på just detta sätt. Jag är intresserad av vad som framkommer i materialet när jag undersöker den medicinska praktiken kring kastrering som behandlingsmetod för prostatahypetrofi med utgångspunkten att alla läkare och kirurger är subjekt som ser saker från vissa positioner. Vad är det som dessa förutsättningar låter dem se? När en läkare såg ner i mikroskopet på den förstorade prostatavävnaden, vad var det han tyckte sig se? Hur förklarade han sina observationer? Och hur påverkade dessa observationer kunskapsproduktionen inom medicinen?

I analysen av de vetenskapliga berättelserna i mitt material har jag haft nytta av Haraways begrepp "historieberättande" (story-telling). ${ }^{51}$ Detta begrepp innebär att vetenskap kan ses som en historieberättande praktik på två olika nivåer. Dels skapar vetenskap olika berättelser genom både teori och praktik, dels är vetenskap en del av större berättelser. De sätt på vilket dessa berättelser kan berättas är, enligt Haraway, regelstyrda, tvingande och historiskt föränderliga, och alla vetenskapliga utsagor om världen är intimt beroende av språk och metaforer, vilka formar den vetenskapliga blicken. ${ }^{52}$ Som exempel på en sådana vetenskapliga berättelser anför hon de berättelser om "mannen som jägare och kvinnan som del i mor-barnparet" som dominerade primatforskningen från mitten av 1950-talet till mitten av 1970-talet. Dessa berättelser gjorde att mycket av forskningen kretsade kring hur mänskliga kvinnor och män skulle förhålla sig till detta i det moderna samhället. Frågor om vad kvinnors inträde på arbetsmarknaden fick för konsekvenser för samhället, hur mycket och vilken sorts omvårdnad små barn

\footnotetext{
${ }^{51}$ Donna Jeanne Haraway, Primate visions: gender, race and nature in the world of modern science, Verso, London, 1992[1989], s. 4.

52 Haraway 1992, s 4.
} 
behövde och vilken stress som drabbade män som skulle leva i urbana miljöer fast de var anpassade för jägar- och samlarsamhällen diskuterades..$^{53}$

Läkarna och kirurgerna i mitt material skriver olika vetenskapliga berättelser: berättelser om vad prostatan är, vad prostatahypertrofi är, varför kastrering fungerar som behandling vid prostatahypertrofi och med tiden berättelser om varför den inte fungerar. Alla dessa berättelser har som syfte att legitimera beskrivningar och praktiker, och att sprida dem. För att något ska ses som en sjukdom och för att en behandlingsmetod ska kunna användas krävs en berättelse som uppfyller samtidens normer för vad som är övertygande och för hur en berättelse ska se ut. Det är viktigt att dessa berättelser kan övertyga om att till exempel djurexperiment kan visa vissa saker eller att obduktioner kan visa andra saker. Berättelsen är en komplex uppbyggnad av olika praktiker och teorier som helst ska måla upp en sammanhängande bild för att visa varför ett objekt är si och så eller varför en behandlingsmetod kommer att fungera.

\section{Spektrum}

I kapitlet om djurförsök kommer jag att använda ett annat av Haraways analytiska begrepp, "avlivningsbarhet" (killability), men i den mer vidareutvecklade formen "spektrum av avlivningsbarhet” utifrån genusvetaren Tara Mehrabis definition. Att vara avlivningsbar är att vara möjlig att avliva för andras skull, oftast rör det sig om mindre djur och organismer i till exempel försökslaboratorier. Med begreppet "spektrum" fångar Mehrabi de dynamiska relationer, däribland maktrelationer, som kan avgöra en varelses avlivningsbarhet, men även det arbiträra och flytande i hur detta går till. ${ }^{54}$ Barads agentiella snitt är enligt

\footnotetext{
${ }^{53}$ Haraway1992, s. $126-127$.

${ }^{54}$ Begreppet "spektrum" har använts inom queerfeministiska teorier. Till exempel har Anne Fausto-Sterling skrivit om könsidentitet och mänsklig sexualitet som ett spektrum. Anne
} 
Mehrabi den gränsskapande praktik som gör att vissa djur är avlivningsbara och inte andra. ${ }^{55}$ Hon skriver: "The spectrum is then performed, and performative, it is agential and agentially enacted, material and discursive." 56 På detta sätt finns det en hierarki som skapas på olika sätt i olika sammanhang. Vissa djur, men inte andra, kan ses som avlivningsbara för att undersöka behandlingsmetoder avsedda för människor.

Med hjälp av detta teoretiska ramverk blir det möjligt för mig att analysera mediciniska artiklar, debattartiklar, publicerade föreläsningar, bokrecensioner och böcker och i dem finna spår av konkreta medicinska praktiker. Jag kan därmed både visa hur läkare skapade prostatan som ett kunskapsobjekt och åskådliggöra hur denna kunskapsproduktion fick praktiska konsekvenser, till exempel vad gäller hur läkare såg prostatan som körtel och hur det påverkade diagnosen prostatahypertrofi och valen av olika behandlingsmetoder.

Fausto-Sterling, Sexing the body: gender politics and the construction of sexuality, Basic Books, New York, 2000, s. 10, 20, 76.

55 Tara Mehrabi, Making Death Matter: A Feminist Technoscience Study of Alzheimer's Sciences in the Laboratory, Linköping University, Department of Thematic Studies, (Diss), Linköpings universitet, 2016, s. $179-180$.

${ }^{56}$ Mehrabi 2016, s. 181. 


\section{Forskningsläge}

Denna avhandling har flera fokus och gränsar till flera större forskningsområden inom det medicinhistoriska fältet, ett fält som i sin tur omfattar forskare från många disciplinära bakgrunder, huvudsakligen den medicinska och de historiska eller samhällsvetenskapliga. De två sistnämnda har ofta fokuserat på samhället, kulturen och de idéhistoriska perspektiven på medicin, och bland dessa återfinns de flesta av de studier som jag diskuterar i denna avhandling. ${ }^{57}$

Den dominerande traditionen i medicinhistorisk forskning är att välja en tidsperiod, exempelvis det långa 1800-talet, och undersöka hur det omgivande samhället under denna tid påverkade medicinens utveckling och praktik. Jag har valt att zooma in på en kortare period, 1893-1910, och att under denna kortare period studera en enskild behandlingsmetod för en sjukdom utifrån den inommedicinska debatten och praktiken. Min studie har därför mer gemensamt med de studier på senare år som fokuserat på en sjukdom, diagnos eller behandling. ${ }^{58}$ Med denna inriktning vill jag inte på något sätt hävda att samhället inte skulle ha påverkat debatten om kastrering som behandlingsmetod för prostatahypertrofi, utan att anlägga ett lite annorlunda perspektiv i medicinhistoria skriven av en

${ }^{57}$ George Weisz, "Making Medical History", Bulletin of the History of Medicine, vol. 80, nr. 1, våren 2006, s. 153 - 159 (Review).

${ }^{58}$ Gerald Grob, "The rise and decline of Tonsillectomy in Twentieth-Century America", Fournal of the History of Medicine and Allied Sciences, vol. 62, nr. 4, 2007; Louis Dwyer-Hemmings, “'A Wicked Operation?' Tonsillectomy in Twentieth-Century Britain”, Medical History vol. 62, nr. 2, 2018, s. 217 - 241; Elizabeth Siegel Watkins, "Medicine, Masculinity, and the Disappearance of Male Menopause in the 1950s", Social History of Medicine, vol. 21, nr. 2 , 2008, s. 329 - 344. 
historiker. Jag vill bidra till den forskning som visat hur den medicin som rört mäns kroppar varit minst lika påverkade av samhället runtomkring, som den som rört kvinnors.

\section{Mäns kroppar och sexualitet}

Ett fält som därmed tangerar min studie är forskningen om manliga kroppar och framförallt mäns sexualitet. Inom detta fält har prostatan studerats historiskt, delvis med fokus på prostatahypertrofi. ${ }^{59}$ Dessutom finns det studier om prostatakirurgins historia när det gäller andra prostataproblem som prostatacancer. ${ }^{60}$ De främsta studierna av maskulinitet och manlighet i förhållande till prostatan är historikern Timothy O'Neills och historikern Christopher O'Sheas avhandlingar, som båda berör ämnet kastrering som behandlingsmetod för prostatahypertrofi. O’Neill utgår från Laqueurs påstående att testiklarna ansågs vara "heliga" eller "förbjuden mark" och argumenterar för att manlig kastrering, som aldrig varit särskilt vanligt, blev ännu ovanligare under

59 Timothy O’Neill, The Invisible Man? Problematising Gender and Male Medicine in Britain and America, 1800-1950, (Diss.) Center for the History of Science, Technology and Medicine, University of Manchester, 2003, s. 129 - 159; Christopher David O’Shea, Visions of Masculinity: Home-health Advice Literature, Medical Discourse and Male Sexuality in English-Canada, 1870-1914, (Diss.) University of Guelph, Ottawa: National Library of Canada, 2003, s. 178 - 21; Christopher David O'Shea, “'A Plea for the Prostate': Doctors, Prostate Dysfunction, and Male Sexuality in Late $19^{\text {th }}$ - and Early 20th Century Canada", Canadian Bulletin of Medical History, vol. 29, nr. 1, våren 2012, s. 7 - 27; Harry Shelley, "The Enlarged Prostate. A brief history of its treatment", Journal of the History of Medicine and Allied Sciences, vol. 24, nr. 4, 1969, s. 452 - 473.

${ }^{60}$ Helen Valier, A History of Prostate Cancer. Cancer, Men and Medicine, Basingstoke: Palgrave Macmillan, 2016; D. Shackley, "A centrury of prostatic surgery”, BfU International, vol. 83, nr. 7, 1999, s. 776 - 782; Sally Wilde, "See One, Do One, Modify One: Prostate Surgery in the 1930s.”, Medical History, vol. 48, nr. 3, 2004, s. 351 - 366. Sally Wildes studie tar alltså vid ungefär där denna avhandling slutar och fokuserar på den fortsatta utvecklingen av prostatakirurgin under 1930-talet. 
1800-talet - till skillnad från kvinnlig kastrering. Han kopplar den utvecklingen till att manlig kastrering under 1800-talet betraktades som ett hot mot maskulinitet och manlig identitet. O’Neills diskussion behandlar utifrån denna utgångspunkt kastrering som behandlingsmetod för prostatahypertrofi i relation till samhällets och läkarvetenskapens syn på manlighet och maskulinitet kopplat till testiklarna. ${ }^{61}$

O’Shea ser istället prostatan som en väg in för de viktorianska läkarna att i slutet av 1800-talet få kontroll över även de manliga patienterna, på samma sätt som kvinnliga patienter, och framförallt deras sexualitet. I en kombination av traditionen att göra moraliska tolkningar av manlig sexuell dysfunktion och viljan att utveckla kirurgiska tekniker för att behandla problem med könsorganen och manlig sexualitet blev prostatan enligt O’Shea nyckeln till att lösa manliga hälsoproblem. Att kastrering och vasektomi ${ }^{62}$ övergavs hade enligt O’Shea att göra med att patienterna protesterade och inte så mycket med att andra behandlingsmetoder med tiden blev bättre och säkrare. ${ }^{63}$ I sin artikel "A Plea for the Prostate" utvecklar han ytterligare kopplingen till manlig sexualitet och menar att även onani och andra sexuella beteenden som bedömdes som skadliga

${ }^{61}$ O’Neill 2003, s. $129-159$.

62 Vasektomi innebär idag, och även runt sekelskiftet 1900, att sädesledaren skärs av eller blockeras. Det fanns ett antal olika varianter som beskrivs i materialet där ibland sädesledarna skars av, knöts av eller knöts av för att sedan skäras av. I vissa fall var det även hela sädessträngen som skars av eller knöts av, och i vissa fall sädesledaren och vissa nerver eller blodkärl i sädessträngen. Rent medicinskt ger dessa olika metoder olika effekt på kroppen då en vasektomi enligt dagens definition, alltså att endast sädesledaren skärs av eller att ett inplantat sätts in, inte medför atrofi av testiklarna. När däremot blodkärl skärs av och/eller nerver skadas kan atrofi av testiklarna uppstå, vilket var vad man under denna period ville uppnå. Oavsett operationsmetod var syftet detsamma och dessa skillnader har ingen påverkan på analysen. Jag kommer därför för enkelhetens skull referera till alla dessa varianter som vasektomi.

63 O’Shea 2003, s. $178-214$. 
kopplades till prostatahypertrofi och andra prostatabesvär i Kanada under sent 1800-tal och tidigt 1900-tal. ${ }^{64}$

O’Neill och O'Shea utgår i stor utsträckning från medicinsk rådgivningslitteratur från 1800-talet och tidigt 1900-tal, medan jag har fokuserat på den debatt som fördes inom medicinen. Därför ligger föreställningar om maskulinitet och manlighet inte i förgrunden på samma sätt i min studie, utan jag analyserar istället hur behandlingen legitimerades och övergavs utifrån medicinska teorier och praktiker. Varför föreslogs behandlingen över huvud taget om testiklarna var så tydligt kopplade till maskulinitet och manlig identitet? Och hur förklarade läkare och kirurger själva att metoden accepterades och sedan övergavs inom loppet av drygt tio år? O’Sheas material består främst av artiklar och rådgivningslitteratur som publicerades i engelska Kanada under senare delen av 1800-talet och tidigt 1900-tal. Den koppling mellan manlig sexualitet och prostatan som han lyfter fram tycks framkomma tydligare i rådgivningslitteraturen och de medicinska texter han studerat än de $\mathrm{i}$ mitt material, och hans studie ligger nära många andra studier om manlig sexualitet under 1800-talet och det moraliskt fördärvliga med onani och annan omoralisk sexuell aktivitet. Dit hör sexualhistorikern Angus McLarens Impotence. A cultural history, böcker och artiklar av medicinhistorikern Robert Darby samt ett antal andra texter som belyser ämnet ur olika perspektiv. ${ }^{65}$ När det gäller svenska

${ }^{64}$ O'Shea 2012, s. 7-27.

${ }^{65}$ Robert Darby, "William Acton's Antipodean Disciples: A Colonial Perspective on His Theories of Male Sexual (Dys)Function”, Fournal of the History of Sexuality vol. 13, nr. 2, apr., 2004, s. 157 - 182; Robert Darby, A Surgical Temptation. The Demonization of the Foreskin and the Rise of Circumcision in Britain, University of Chicago Press, 2005a; Robert Darby, "Pathologizing Male Sexuality: Lallemand, Spermatorrhea, and the Rise of Circumcision", Fournal of the History of Medicine and Allied Sciences, vol. 60, nr. 3, 2005b, s. 283 - 319; Angus McLaren, Impotence: a cultural history, University of Chicago Press, Chicago, 2007; Ellen Bayuk Rosenman, "Body Doubles: The Spermatorrhea Panic", Fournal of the History of Sexuality, vol. 
studier har idéhistorikerna Claes Ekenstam och Maja Bondestam (f. Larsson) undersökt läkarvetenskapen och rådgivningslitteraturens inställning till bland annat onani, skadliga sexuella beteenden och manlig sexualitet under 1800-talet och första halvan av 1900-talet. ${ }^{66}$

Jag har dock inte hittat någon koppling mellan prostatahypertrofi och onani i de medicinska artiklar och kirurgiböcker jag undersökt, och inte heller har de läkare och kirurger som kommer till tals i mitt material särskilt mycket att säga om manlig sexualitet kopplad till prostatan, kanske för att jag har fokuserat på kastreringsdebatten. Det nämns i förbigående att sexuella excesser eller "ett andra äktenskap med en ung fru" skulle kunna bidra till prostatahypertrofi men att det inte finns några bevis för detta. ${ }^{67}$ Tidigare forskning visar dock tydligt att män under denna period inte på något sätt var undantagna från tidens moralisering i form av restriktioner, tabun och hot om de hälso- och livsfarliga tillstånd som kunde bli följden av vissa sexuella handlingar och beteenden. ${ }^{68}$ Historikern

12, nr. 3, juli 2003, s. 365 - 399; Elizabeth Stephens, "Pathologizing Leaky Male Bodies. Spermatorrhea in Nineteenth - Century British Medicine and Popular Anatomical Museums", Fournal of the History of Sexuality, vol. 17, nr. 3, september 2008, s. 421 - 438; Timothy Verhoeven, "Pathologizing Male Desire: Satyriasis, Masculinity, and Modern Civilization at the Fin de Siecle", Fournal of the History of Sexuality, vol. 24, nr. 1, januari 2015, s. $25-45$.

${ }^{66}$ Claes Ekenstam, Kroppens idéhistoria: disciplinering och karaktärsdaning i Sverige 1700 - 1950, (Diss.) Gidlund, Hedemora, 1993; Maja Larsson (Bondestam), Den moraliska kroppen: tolkningar av kön och individualitet i 1800-talets populärmedicin, (Diss.) Gidlund, Hedemora, 2002.

${ }^{67}$ White tar upp detta och anger Mr. Buckston Browne som den läkare som tyckt sig se ett samband mellan detta hos sina patienter. William White, "The results of double castration in hypertrofy of the prostate", Annals of Surgery, vol. 22, 1895d, s. 2.

${ }^{68}$ För en studie av hur svårt det var för läkarkåren att övertyga män om de restriktioner kring sexlivet som efterfrågades kring sekelskiftet och början av 1900-talet se Timothy Verhoeven, "'Apostles of Continence': Doctors and the Doctrine of Sexual Necessity in Progressive-Era America", Medical History, vol. 61, nr. 1, 2017, s. 89 - 106. 
Christina Benninghaus menar att forskning som genomförts under de senaste två decennierna utmanat synen på kvinnokroppen som utsatt för patologisering och män som undantagna. Studier av medikaliseringen av den manliga kroppen, impotens, spermatorré (olika former av spermaläckage), det manliga klimakteriet och experimenten med vitalisering har kunnat visa att även manskroppen varit utsatt för detta. ${ }^{69}$ Detta är också ett forskningsfält jag vill bidra till med denna studie.

\section{Kirurgi}

Ett annat fält som tangerar min avhandling är forskningen om kirurgins framväxt under 1800-talet och tidigt 1900-tal. ${ }^{70}$ Bland dem som forskat om prostatakirurgi vill jag nämna medicinhistorikern Helen Valier, som främst behandlar kirurgin kring prostatacancer men även tar upp kirurgi för prostatahypertrofi och kastrering. ${ }^{11}$ Medicinaren Harry Shelley var en av de som tidigt beskrev utvecklingen av prostatakirurgi. Han har kortfattat beskrivit behandlingsmetoder

${ }^{69}$ Christina Benninghaus, "Beyond Constructivism?: Gender, Medicine and the Early History of Sperm Analysis, Germany 1870-1900”, Gender ङ History, vol.24, nr.3, november 2012, s. 647 - 676; Sally Frampton, Belly-Rippers, Surgical Innovation and the Ovariotomy Controversy [Elektronisk resurs], Springer International Publishing, 2018.

${ }^{70}$ Se bland annat Christopher Lawrence, "Democratic, Divine and Heroic: The History and Historiography of Surgery" i Medical Theory, Surgical Practice, ed. Christopher Lawrence, London: Routledge, 1992; Owsei Temkin, "The Role of Surgery in the Rise of Modern Medical Thought", Bulletine of the History of Medicine, vol. 25, nr. 3, 1951, s. 218 - 50; Thomas Schlich, "The Emergence of Modern Surgery" i Medicine Transformed, Health, Disease and Society in Europe 1800-1930, ed. Deborah Brunton, Milton Keynes, UK: Open University Press, 2004; Thomas Schlich, “"Physiological surgery”. Laboratory Science as the Epistemic Basis of Modern Surgery (and Neurosurgery)" i Casper, Stephen T. \& Gavrus, Delia (red.), The history of the brain and mind sciences: technique, technology, therapy, University of Rochester Press, Rochester, 2017.

${ }^{71}$ Valier 2016. 
från de första palliativa åtgärderna före 1800 till de mer radikala och kirurgiska ingrepp som blev allt vanligare under 1800- och 1900-talet. ${ }^{72}$ Medicinaren David Shackley har kortfattat skrivit om behandlingsmetoder och kirurgiska ingrepp för olika prostataproblem framförallt från 1895 till sent 1990-tal. ${ }^{73}$ Och medicinhistorikern Sally Wilde har skrivit om prostatakirurgi under perioden precis efter min undersökningsperiod. ${ }^{74}$

När det gäller avlägsnandet av körtlar och organ hos kvinnor har det gjorts en hel del historiska studier. ${ }^{75}$ Dessa studier behandlar delvis hur äggstockar och livmödrar opererats bort för att behandla diverse åkommor som ansågs drabba kvinnor men där äggstockarna eller livmodern var friska. De är intressanta för min studie av jämförelseskäl. Kastrering som behandling mot prostatahypertrofi är ett av de ingrepp under perioden då män kan sägas ha behandlats på ett liknande sätt, att friska körtlar tillhörande det sexuella systemet opererades bort för att bota ett problem i ett annat organ eller annan körtel i kroppen.

Lämnar vi könsorganen och könskörtlarna finns det ett antal historiska studier av medicinska ingrepp där andra körtlar eller organ opererats bort, ofta utan vidare kunskap om vilken roll dessa spelade för människors hälsa eller kroppens funktion. Historikern Keith Wailoo har skrivit om en metod som var

\footnotetext{
72 Shelley 1969.

73 Shackley 1999.

${ }^{74}$ Wilde 2004.

75 Se bland annat Frampton 2018; Ann Dally Women under the knife: a history of surgery,
} Hutchinson Radius, London, 1991; Ann Dally Fantasy Surgery, 1880-1930: With Special Reference to Sir William Arbuthnot Lane, Rodopi, Amsterdam, 1996; Ulrika Nilsson, Kampen om kvinnan: professionalisering och konstruktioner av kön i svensk gynekologi 1860-1925, (diss.) Univ., Uppsala, 2003; Ornella Moscucci, The science of woman: gynaecology and gender in England, 1800-1929, Cambridge University Press, Cambridge, 1990; Chandak Sengoopta The Most Secret Quintessence Of Life : Sex, Glands, And Hormones, 1850-1950, Chicago: University of Chicago Press, 2006; Karin Johannisson Den mörka kontinenten: Kvinnan, Medicinen och Fin-De-Siècle, Stockholm. Norstedt, 1995. 
populär i början av 1900-talet: att operera bort mjälten för att bota de anemiska symptom som vissa patienter uppvisade, enligt resonemang om att mjälten skulle påverka en sjukdom i en annan del av kroppen. Sjukdomen kallades mjältanemi (splenic anemia). ${ }^{76}$ Historikern Gerald Grob och medicinaren Louis DwyerHemmings har i var sin studie visat att tonsillektomier (bortoperering av halsmandlarna) populariserades under början av 1900-talet och användes in på 1960-talet, trots att läkarvetenskapen var osäker på vad tonsillerna hade för funktion i kroppen och att det inte fanns några tydliga resultat som visade att ingreppen minskade de besvär de var avsedda att minska. ${ }^{77}$ Medicinhistorikern Thomas Schlich har i ett omfattande verk studerat bortopererandet och transplanterandet av ett stort antal organ och körtlar mellan 1880 och $1930 .{ }^{78}$

Även medicinaren Ann Dally har undersökt förekomsten av operationer mellan åren 1880-1930 där till synes friska organ opererades bort för att bota diffusa symptom som var svåra att knyta till en somatisk orsak. Hon delar in ingreppen i "empirisk kirurgi" och "teoretisk kirurgi", som hon också kallar "fantasikirurgi". Fantasikirurgiska ingrepp motiverades med en teoretisk idé, men det saknades empiriska belägg för att de var effektiva. Skillnaden mellan empirisk kirurgi och fantasikirurgi menar Dally egentligen mest ligger i hur länge de underliggande teorierna har accepterats. De ingrepp som byggde på empiriska bevis tycks ha använts under längre tid än de som byggde på en teori om till exempel "kvinnans natur". De flesta exempel som Dally tar upp är bukkirurgi, varav flera operationer på kvinnor som ovariektomi och hysterektomi. ${ }^{79}$

\footnotetext{
${ }^{76}$ Keith Wailoo, Drawing blood: technology and disease identity in twentieth-century America, Johns Hopkins University Press, London, 2000.

77 Grob 2007; Louis Dwyer-Hemmings 2018.

78 Thomas Schlich, The origins of organ transplantation: surgery and laboratory science, 1880-1930, University of Rochester Press, Rochester, NY, 2010.

${ }^{79}$ Dally 1996.
} 
Flera av de ovan diskuterade studierna behandlar skapandet av kunskapsobjekt inom medicinen. Wailoos studie visar hur mjälten skapades som ett organ som kunde orsaka en form av anemi och därigenom tillskrevs vissa egenskaper i kroppen avskilda från andra organ. På samma sätt visar Grobs studie hur tonsillerna konstruerades som en port in i kroppen för bakterier (även om det var oklart vad tonsillerna hade för funktion i övrigt). Dessa studier pekar på den trend som flera gånger påpekats i medicinhistoriska studier: vurmen för kirurgi från 1800-talets slut och framåt. Man sökte kirurgiska lösningar på så många sjukdomar som möjligt och föreställde sig att avlägsnandet av en körtel eller ett organ kunde bota en sjukdom i en annan körtel, ett annat organ eller en helt annan del av kroppen. Det är som en del av denna trend som kastrering för att behandla prostatahypertrofi måste förstås. ${ }^{80}$

\section{Skapandet av diagnoser}

Denna avhandling handlar om skapandet av prostatan och testiklarna som kunskapsobjekt och prostatakirurgi och kastrering som behandlingsmetoder. Den handlar dessutom om hur diagnosen prostatahypertrofi skapades och förändrades. En tidigare studie av framväxten av en diagnos är historikern Elizabeth Siegel Watkins artikel om hur den manliga menopausen skapades som en diagnos under det sena 1930-talet, när syntetiskt hormon för första gången kom ut på den medicinska marknaden, och hur den sedan försvann efter 1950-talets mitt när de symptom som tidigare tillskrivits en manlig menopaus (andropaus) istället tolkades som utlösta av stress och det moderna samhällets krav på män. ${ }^{81}$ Medicinhistorikern Thomas Schlich har undersökt hur definitioner av diagnosen

\footnotetext{
${ }^{80}$ För en mer nyanserad bild av inställningen till kirurgi runt sekelskiftet 1900 se Lawrence 1992; Clair Brock, "Risk, Responsibility and Surgery in the 1890s and Early 1900s", Medical History, vol. 57, nr. 3, 2013, s. $317-337$.

${ }^{81}$ Siegel Watkins 2008.
} 
kretinism förändrades från mitten till slutet av 1800-talet och hur detta var kopplat till upptäckten av sköldkörteln och dess inverkan på kroppen. Från att ha kopplats till vissa geografiska platser kopplades diagnosen kretinism nu till sköldkörtelns funktion. ${ }^{82}$ Dessa studier visar på hur diagnoser dels hela tiden förändras och dels hur detta är kopplat både till samhällets föreställningar kring exempelvis maskulinitet men även medicinska uppfinningar som syntetiskt hormon eller upptäckten av sköldkörtelns inverkan på kroppen.

När det gäller prostatahypertrofi handlade diagnosens förändringar och dess olika definitioner i olika länder mycket om hur man förstod prostatan. Var den en körtel eller en muskel? Tillhörde den urinorganen eller de sexuella organen? Var sjukdomen lokal eller en del av en annan större sjukdom? På ett liknande sätt förändrades definitionen av behandlingarna utifrån hur prostatan och testiklarna förstods - som essentiella eller inte för den manliga kroppens fullständiga funktion. Under perioden gav experiment, observationer av patienter och klinisk erfarenhet ständigt ny kunskap om dessa körtlar och deras funktioner i kroppen.

\section{Manlig kastrering}

Manlig kastrering har inte tilldragit sig speciellt mycket intresse från medicinhistoriker, men det finns ett litet antal studier som tar upp det. Socialhistorikern Melissa S. Dale har skrivit om västerländska läkare som praktiserade i Kina, om deras studier under 1890-talet av kinesiska eunucker och vilka effekter kastrering hade på dem. Den kinesiska formen av kastrering innebar att alla de yttre könsdelarna skars av så nära kroppen som möjligt, alltså både penis och pung, medan den västerländska formen innebar att testiklarna avlägsnades men penis och pung lämnades intakta. Dale noterar att studierna av dessa eunucker och de urineringsproblem de drabbades av bidrog till

82 Thomas Schlich, "Changing Disease Identities: Cretinism, Politics and Surgery (1844 1892)", Medical History, vol. 38, nr. 4, 1994, s. $421-443$. 
behandlingar av sådana problem i västvärlden, eftersom de kinesiska eunuckerna ofta fick liknande urineringsproblem som patienter med prostatahypertrofi. Studierna av de kinesiska eunuckerna blev dessutom ett inlägg i den diskussion om manlig kastrering som fördes i västvärlden från sent 1800-tal till 1930-talet då läkare övervägde att kastrera kriminella, "vansinniga" och psykiskt instabila personer - som ett straff, en behandling för sexuellt perverterade och en bot för vansinniga och svagsinta, enligt Dale. I dessa diskussioner blev studierna av kinesiska eunucker viktiga för att förstå långtidseffekterna av kastrering på kroppen. ${ }^{83}$

Medicinhistorikern Thomas Bryants studie handlar om kastrering i relation till steriliseringsdebatten under den senare delen av kejsardömet Tyskland och den tidiga Weimarrepubliken, från sent 1800-tal till 1933. Kastrering, av både män och kvinnor, föreslogs i början av perioden men övergavs snabbt till förmån för olika former av vasektomi eller blockering av äggledarna. Argumenten mot att kastrera kriminella eller sexuellt perversa var bland annat att det skulle behöva göras tidigt i livet för att ha god effekt och att man inte kunde vara säker på att kastrering omöjliggjorde fortplantning eller minskade sexdriften. ${ }^{84}$

Dessa studier belyser främst andra sidor av manlig kastrering, inte medicinska ingrepp för att bota en somatisk sjukdom. I Dales fall handlar det om den tusenåriga traditionen att på olika sätt, och på olika platser i världen, kastrera män för att skapa eunucker. Dessa har sedan upptagit olika platser i samhällshierarkin som bland annat rådgivare, haremsvakter och i fallet i Kina palatstjänare i den Förbjudna Staden. I Bryants fall handlar det om kastrering som ett sätt att kontrollera kriminella eller mentalt sjuka personers förmåga att

${ }^{83}$ Melissa S. Dale, "Understanding Emasculation: Western Medical Perspectives on Chinese Eunuchs", Social History of Medicine, vol. 23, nr. 1, 2010, s. 38 - 55.

84 Thomas Bryant, "Sexological Deliberation and Social Engineering: Albert Moll and the Sterilisation Debate in Late Imperial and Weimar Germany”, Medical History, vol. 56, nr. 2, 2012, s. $237-254$. 
fortplanta sig, som straff eller som ett möjligt sätt att behandla olika former av mental ohälsa.

\section{Endokrinologi}

Förståelsen för testiklar, ovarier och andra körtlars funktion i kroppen studeras inom fältet endokrinologins historia. Framväxten under den senare delen av 1800talet av det kunskapsfält som skulle bli endokrinologin, och de kunskaper som producerades om det mänskliga endokrina systemet runt sekelskiftet 1900, kom att påverka synen på kastrering som behandlingsmetod för prostatahypertrofi. Om detta har historikern Chandak Sengoopta genomfört en omfattande studie. ${ }^{85}$ Han visar att läkarvetenskapen under 1800-talets lopp rörde sig från en föreställning om att kroppen styrdes av nervsystemet till en föreställning om att den styrdes av inre sekretioner. Under en övergångsperiod, till stod del under den period jag undersöker, kombinerades nervsystemsteorin med teorin om inre sekretion. Det gjordes en hel del experiment på både djur och människor, som kastrering, inplantering av könskörtlar i buken på djur och diverse operationer på kvinnor, men Sengoopta håller med O’Neill och Laqueur om att testiklarna under den senare halvan av 1800-talet och runt sekelskiftet 1900 behandlades som heliga. Sengoopta skriver att "the testicle, the symbol of virility for aeons, remained largely free from medical interference except in clear cases of intrinsic abnormality" och nämner kastrering för prostatahypertrofi endast i en not. ${ }^{86}$

\section{Könskategoriseringar}

En del av de diskussioner om kastrering för prostatahypertrofi som fördes runt sekelskiftet hade också att göra med könskategoriseringar och förståelsen av manliga, kvinnliga och vad jag i den här avhandlingen kallar avvikande kroppar.

85 Sengoopta 2006.

${ }^{86} \mathrm{Ibid}$, s. 29. I not 92 på denna sida nämns kastrering för prostatahypertrofi. 
Historikern Thomas Laqueur har skrivit övergripande om hur synen på kön och biologi förändrats genom historien, och han menar att den stora förändringen i synen på kön inträffade när man under 1700-talet gick från vad han kallar en enkönsmodell till en tvåkönsmodell. Från att mannen hade setts som en hel människa och kvinnan som en inte fullt utvecklad man så skildes nu könen åt och blev två separata varelser. ${ }^{87}$

Laqueurs enköns- och tvåkönsmodell har dock fått kritik från flera historiker. Katharine Park och Robert Nye menar bland annat att en närmare läsning av materialet innan 1750-talet inte ger en enhetlig bild av en enkönsmodell. Dessutom bortser Laqueur helt, i sin analys av perioden från 1750 och framåt, från att även mäns sexualitet och könsroller, precis som kvinnors, är socialt konstruerade. ${ }^{88}$ Christina Benninghaus har också lyft kritiken mot Laqueur och poängterar att förutom de felaktiga tolkningarna av historiskt material, som även Michael Stolberg påpekat, så finns det ett problem med den socialkonstruktivistiska analysen. "[T]o stress that all medical knowledge reflects cultural beliefs and that 'political questions regarding the nature of women' were always at stake when biology was discussed, can easily lead not only to a rather dismissive attitude towards that knowledge, and the people who produced it, but to a reading of history that is ahistorical or 'flat"' menar Benninghaus. ${ }^{89}$

Vetenskapshistorikern Londa Schiebinger menar att en stor förändring i synen på kön i slutet av 1700-talet var att skillnaden mellan könen inte längre ansågs vara begränsad till könsorganen. Enkönsmodellen hade beskrivit män och

87 Thomas Laqueur, Making Sex: Body and Gender from the Greeks to Freud, Harvard University Press, Cambridge, Mass., 1992.

${ }^{88}$ Katharine Park \& Robert Nye, "Destiny is anatomy [Review of: Making sex: Body and Gender from the Greeks to Freud", The New Republic: A Journal of Politics and the Arts, vol. 18, 1991, s. 53, 56. ${ }^{89}$ Benninghaus 2012, s. 650 - 652; Michael Stolberg, "A Woman Down to Her Bones: The Anatomy of Sexual Difference in the Sixteenth and Early Seventeenth Centuries", Isis, vol. 94, nr. 2, juni 2003, s. $274-299$. 
kvinnor som lika, med kvinnan som en inte fullt utvecklad man, och den enda fysiska skillnaden var egentligen könsorganen. Från och med slutet av 1700-talet hävdade dock allt fler att skillnaderna fanns i hela kroppen, i alla organ, och att män och kvinnor var helt biologiskt skilda varelser. ${ }^{90}$ Även historikern Angus McLaren, i sin studie av impotens, och den svenska idéhistorikern Karin Johannisson har skildrat hur de biologiska skillnaderna mellan män och kvinnor framhölls som allt större och mer avgörande under 1800-talet. ${ }^{91}$

Dessa föreställningar innebar en ökad vilja under 1800-talets gång att kunna dela in alla människor i de två könskategorierna man och kvinna. Runt sekelskiftet 1900 hade kategorin hermafrodit, som utgjort en tredje kategori åtminstone medicinskt, om än inte samhälleligt, försvunnit. Ett antal medicinhistoriska studier har undersökt detta i olika länder i västvärlden. Maja Bondestam visar att kroppar sedan 1600-talet hade kunnat befinna sig på ett kontinuum mellan kvinnliga eller manliga, men övertygelsen att alla kroppar hade ett "sant" kön och att det gick att hitta vann mark under 1800-talet och hade vid seklets slut blivit dominerande. ${ }^{92}$ Enligt historikern Alice Domurat Dreger var det framförallt det sena 1800-talets fokus på körtlar som gjorde att läkare ansåg att alla personers "sanna" kön gick att finna. ${ }^{93}$ Historikern Geertje Mak visar att det i tvivlet på vilket kön vissa patienter tillhörde under en stor del av 1800-talet fanns ett utrymme att till och med låta individer själva välja vilket kön de ville tillhöra, men de var tvungna att

${ }^{90}$ Londa Schiebinger, The Mind has no Sex?: Women in the Origins of Modern Science, Harvard University Press, 1991.

${ }^{91}$ Johannisson 1995; McLaren 2007.

${ }^{92}$ Maja Bondestam, Tvåkönad. Studier i den svenska hermafroditens historia, Bokförlaget Nya Doxa, 2010.

${ }_{93}$ Alice Domurat Dreger, Hermaphrodites and the Medical Invention of Sex [Elektronisk resurs], Harvard University Press, 2000. ProQuest Ebook Central, https://ebookcentral.proquest.com/lib/linkoping-ebooks/detail.action?docID =3300278, 1998. [sidan besökt 2019-10-19] 
välja man eller kvinna. ${ }^{94}$ Vetenskapshistorikern Christina Mattas studie kopplar den ökade rädslan för homosexualitet till en ökning av antalet könsoperationer kring sekelskiftet 1900 för att få alla att passa in i den binära könsuppdelningen. ${ }^{95}$ Och historikern Elisabeth Reis kopplar sekelskiftets hermafroditdiskussioner till den ökade rädslan för homosexualitet och viljan att vid behov operera individer för att de skulle kunna ingå heterosexuella äktenskap. ${ }^{96}$

Dessa frågor kring hermafroditism, vilka vållade en hel del oro inom läkarvetenskapen, aktualiserades i diskussionen om kastrering främst $\mathrm{i}$ två sammanhang. Dels befarade man att kastrering skulle göra män feminina eller kvinnor maskulina, och dels handlade det om män som avvek på olika sätt men ändå aldrig ifrågasattes som just "män" eftersom det inte fanns något utrymme för att klassas som något annat än man eller kvinna. Män hos vilka inga testiklar kunde upptäckas var ändå män, baserat på hur de i övrigt såg ut, trots den rådande övertygelsen att det var förekomsten av könskörtlar som avgjorde könet. Eunucker utgjorde ett undantag: de klassades konsekvent som en egen grupp, men de ansågs fortfarande vara män, om än ofullständiga sådana. Mycket energi lades på att undersöka på vilka sätt eunucker skilde sig från fullständiga män och liknade kvinnor.

\footnotetext{
${ }^{94}$ Geertje Mak, Doubting sex. Inscriptions, bodies and selves in nineteenth-century hermaphrodite case histories, Manchester University Press, 2012.

${ }^{95}$ Christina Matta, "Ambiguous Bodies and Deviant Sexualities: hermaphrodites, homosexuality, and surgery in the United States, 1850 - 1904”, Perspectives in Biology and Medicine, vol. 48, nr. 1, vintern 2005, s. $74-83$.

${ }^{96}$ Elisabeth Reis, Bodies in Doubt. An American History of Intersex, The Johns Hopkins University Press. Baltimore, 2009; För en ytterligare studie av homosexualitet kopplat till hermafroditism och heterosexualitet som norm se Geertje Mak, "Conflicting Heterosexualities: Hermaphroditism and the emergence of surgery around 1900", Fournal of the History of Sexuality, vol. 24, nr. 3, september 2015, s. $402-427$.
} 


\section{Disposition}

Det första empiriska kapitlet, kapitel 5, handlar om framförallt prostatan men även prostatahypertrofi som kunskapsobjekt. Hur hade de beskrivits och avgränsats tidigare? Och vilka förändringar skedde under 1800-talets gång? Vad ansågs orsaka sjukdomen prostatahypertrofi?

Kapitel 6 är en översikt för att du som läsare ska kunna orientera dig i de kommande empiriska kapitlen, vilka djupdyker ner i argument för och emot kastrering. Först redogör jag kort för de behandlingsmetoder mot prostatahypertrofi som var i bruk i slutet av 1800-talet och deras fördelar och nackdelar. Därefter sammanfattar jag hur och varför kastrering föreslogs som ett behandlingsalternativ.

I det andra empiriska kapitlet, kapitel 7, tittar jag närmare på analogin med uterus eller uterusmyom, vilken anfördes som ett argument för att kastrera män som led av prostatahypertrofi. Jag belyser framförallt de jämförelser som gjordes med den kvinnliga kroppen och de praktiker som överfördes från gynekologin, en medicinsk specialistinriktning med en längre historia som genererat mer kunskap om den kvinnliga kroppen än vad andra delar av den övriga medicinen gjort om den manliga.

I kapitel 8 går jag närmare in på de grupper av avvikande män vars kroppar användes som jämförelse med "normala" manliga kroppar för att skapa kunskap om hur testiklarna påverkade den manliga kroppen och framförallt prostatan, och på hur detta påverkade synen på ensidig och dubbelsidig kastrering.

Det fjärde empiriska kapitlet, kapitel 9, handlar om djurförsökens roll för skapandet av kunskap om prostatan, dess förhållande till testiklarna och kastreringens påverkan på prostatan. Jag studerar vilka djur som användes, varför och vad de ansågs kunna bidra med i kunskapsproduktionen kring kastrering som behandlingsmetod för prostatahypertrofi. 
I den femte empiriska kapitlet, kapitel 10, gör jag dels en jämförelse mellan det sena 1800-talets inställning till att kastrera kvinnor och den inställning till manlig kastrering som framkommer i mitt material, dels studerar jag närmare den oro som framkom i debatten för att manlig kastrering skulle ha en negativ psykisk påverkan.

I det sista empiriska kapitlet, kapitel 11, lyfter jag blicken och knyter ihop säcken genom att redogöra för varför kastrering övergavs som en behandling mot prostatahypertrofi. Kritiken finns genomgående med i alla avhandlingens kapitel, men här tittar jag närmare på den ackumulering av faktorer som gjorde att behandlingsmetoden övergavs.

I det sista kapitlet, kapitel 12, sammanfattar jag mina empiriska och teoretiska resultat och slutsatser. 


\section{Prostatan, prostatahypertrofi och dess etiologi}

The prostate is a glandular body which surrounds the neck of the bladder and the adjacent inch of the urethra. In the adult it is of the size and shape of a chestnut, being about one and a half inches broad, one inch long, and three quarters of an inch deep. Its average weight is six drachms. The base is directed backwards towards the bladder, the neck of which it embraces, and the apex forwards, touching the triangular ligament. The under surface, which is smooth and slightly grooved longitudinally, rests on the rectum, with which it is connected by dense fibrous tissue. The prostate consists of two lateral lobes and a median portion placed at the under and posterior aspect of the organ, between the ejaculatory ducts, which perforate the lower part of the gland obliquely before opening into the prostatic urethra. ${ }^{97}$

Peter Johnston Freyer i The Lancet 1901.

I detta kapitel går jag närmare in på de diskussioner och praktiker som skapade prostatan som ett kunskapsobjekt. Jag går också in på prostatahypertrofi som en diagnos som det var möjligt att förstå och föreslå behandlingar för. Det var framförallt två processer som bidrog till skapandet av prostatan som ett kunskapsobjekt: dels post mortemundersökningar vilka resulterade i att prostatan definierades som ett anatomiskt objekt och dels undersökningarna av prostatans funktion.

Citatet som inledde kapitlet är Peter Johnston Freyers (1851-1921) beskrivning av prostatans anatomi i januari 1901.98 Själva beskrivningen av

97 Peter Johnston Freyer, "Two Clinical Lectures on Enlargement of the Prostate", The Lancet vol. 157, nr. 4037(ursprungligen publicerad som volym 1, nr. 4037) jan. 12, 1901b, s. 79.

${ }^{98}$ Peter Johnston Freyer (1851 - 1921) var en irländsk läkare och kirurg som studerade medicin i Dublin och i Paris. 1874 tog han sin medicine doktorsexamen med högsta betyg och sin 
prostatans form, storlek, olika lober, delar och plats i kroppen skiljer sig inte från hur prostatan beskrivits under större delen av 1800-talet. Freyer hade löst de två tvistefrågor som då diskuterades: om det fanns en tredje lob eller mitenlob och om prostatan endast var en körtel eller även en muskel. Dessa två frågor kommer som jag gå in närmare på i detta kapitel. Av beskrivningen framgår de agentiella snitt som gjorts för att konstruera prostatan som ett kunskapsobjekt. Prostatan är skild från urinblåsan, urinröret, sädesledarna och de omkringliggande ligamenten.

Organ, sjukdomar och behandlingar har alla en egen historia. Vissa diagnoser har bara funnits under vissa perioder, till exempel en rad psykiatriska sjukdomar som neurasteni, hysteri och chlorosis samt olika blodsjukdomar. ${ }^{99}$ Ibland har diagnoserna helt försvunnit och det finns ingen liknande idag. Ibland har de kommit tillbaka under ett nytt namn och ofta en lite annan beskrivning. Vi kan i dagens utmattningssyndrom och ångesttillstånd se spåren av det som en gång kallats neurasteni och hysteri.

Samma princip gäller organ och behandlingsmetoder. Galenos, som levde i det antika Grekland (129 - 199. el. 216) trodde att levern ständigt bildade nytt blod i kroppen. Den övertygelsen levde kvar tills William Harvey i Exercitatio

kirurgie magisterexamen. Mellan åren 1875 och 1896 arbetade Freyer som läkare i Indien och när han avslutade denna anställning blev han utsedd till hedersöverste. Därefter flyttade Freyer till London och fick en tjänst som kirurg vid St. Peter's Hospital for Stone. Prostatektomier användes inte ofta under denna period men Freyers fyra lyckade operationer publicerade 1901 skulle vända denna trend. Freyer blev därefter utsedd till president för den nyligen bildade avdelningen för urologi vid the Royal Society of Medicine. 1904 tilldelades han Arnot Memorial-medaljen för den nyskapande forskning inom olika områden av kirurgi som han bidragit med. "Obituary" The Lancet, vol. 198, nr. 5117 (ursprungligen publicerad som volym 2, nr. 5117) sep. 24, 1921, s. $677-678$.

${ }^{99}$ Se till exempel Mark S. Micale, Hysterical Men: Hidden History of Male Nervous Illness, Harvard University Press, 2008; Edward Shorter, From paralysis to fatigue: a history of psychosomatic illness in the modern era, Free Press, New York, 1992; Elaine Showalter, Hystories: hysterical epidemics and modern culture, Columbia Univ. Press, New York, 1997; Wailoo 2000. 
Anatomica de Motu Cordis et Sanguinis in Animalibus 1628 framlade den första moderna beskrivningen av blodomloppet och hjärtats funktion för att pumpa runt blodet. På samma sätt har prostatans fysiologiska beskrivning och funktion genomgått förändringar, och behandlingar av prostataproblem har kommit och gått.

Kastreringens långa historia innefattar kastrering av kulturella skäl (eunucker) och medicinska skäl (avlägsna sjuka eller skadade testiklar), och därtill kastrering av husdjur för att bland annat påverka deras beteende - vilket skulle komma att påverka kunskapsproduktionen kring användningen av kastrering på människor. ${ }^{100}$ Kastrering övergavs som behandlingsmetod för prostataproblem men återkom ungefär 30 år senare. Och under 1900-talet utvecklades kastreringen från ett fysiskt avlägsnande av testiklarna till en blockering av hormoner för behandling av prostatacancer.

\section{Prostatan fram till 1893}

När kastrering föreslogs som en behandling mot prostatahypertrofi för första gången 1893, vad hade man då inom den europeiska och angloamerikanska medicinen för bild av prostatan? Vad ansågs vara vedertagna fakta och vad rådde det osäkerhet om?

Den svenske läkaren Jaques Borelius $(1859-1921)^{101}$ grep sig med stort intresse an uppgiften att reda ut frågan om kastreringens vara eller icke vara som

100 Kathryn Reusch, "That which was missing": the archaeology of castration, (Diss.) Oxford university, UK, 2013. Tillgänglig genom:

https://ora.ox.ac.uk/objects/uuid:b8118fe7-67cb-4610-9823-b0242dfe900a [sidan besökt 2019-10-17]

${ }^{101}$ Jakob Ludvig (Jacques) Borelius (1859 - 1921) blev medicine licentiat i Uppsala 1887 och medicine doktor i Lund 1890. Mellan 1884 - 1891 innehade Borelius ett antal kortare anställningar i Uppsala, Göteborg, Lund och Karlskrona. Han blev sedan professor i kirurgi vid Karolinska Institutet 1895, professor i kirurgi och obstetrik i Lund 1889 och professor i kirurgi vid Lunds universitet 1899. Han innehade ett antal mer ledande positioner som 
metod för att behandla prostatahypertrofi och konstaterade inledningsvis att "den s. k. prostatahypertrofiens patologi [...] i så många afseenden är dunkel och outredd". ${ }^{102}$ Vad det gällde själva prostatan menade han dock att "[b]ehofvet af en monografisk framställning af hela ämnet synes mig egentligen icke vara så stort". 103 Det fanns nämligen redan ett antal monografier och arbeten om prostatan skrivna av auktoriteter på området. ${ }^{104}$ Borelius diskuterade inledningsvis de olika författarnas beskrivningar av prostatan och dess sjukdomar, men han hänvisade till andra författares iakttagelser och åsikter oftast när de stred mot hans egna. ${ }^{105}$

sjukhusdirektör för Lunds lasarett och generalsekreterare för Nordiska kirurgiska föreningen. Hans främsta gärning som läkare och kirurg var upprustandet av Lunds lasarett där han även införde moderna kirurgiska metoder. Under hela sitt verksamma liv reste Borelius mycket, bland annat till Tyskland, Österrike, Frankrike och England men även Amerika, och han var ledamot för flera utländska kirurgi- och läkarsällskap. Han hade också en stor betydelse för utbildningen av både läkare och sjuksköterskor i Sverige. Riksarkivet https://sok.riksarkivet.se/sbl/mobil/Artikel/17973 [sidan besökt 2019-10-20] ${ }^{102}$ Jaques Borelius "Bidrag till den s. k. prostatahypertrofiens patologi och terapi" del 1, Hygiea, band 59, del 1, februari, 1897a, s. 223.

103 Ibid.

${ }^{104}$ Henry Thompsons, The Diseases of the Prostate, their pathology and treatment; comprising the second edition of "The Enlarged Prostate," and a dissertation "On the healthy and morbid anatomy of the prostate gland," to which the Facksonian prize for the year 1860, was awarded by the Royal College of Surgeons of England, sjätte upplagan, London: J. \& A. Churchill, från 1886; Axel Iversens Hypertrophia Prostate, Kjøbenhavn Gad från 1874; Leopold von Dittels, "Beiträge zur Lehre der Prostatahypertrofi", Medizinische Jahrbücher, band 13, Wien, från 1867; August Socins arbete "Erkrankungen der Prostata", Chirurgie Band III. Erlangen 1873, men även senare verk som Jean Casimir Félix Guyons Leçons cliniques sur les affections chirurgicales de la vessie et de la prostate, Paris : J.-B. Baillière, från 1888; Charles William Mansell Moullins Enlargement of the Prostate från 1894a och Henri Picards Traité des Maladies de la Prostate et des vésicules séminales, Paris: G. Carré, från 1896.

105 Borelius 1897a, s. 223. 


\section{Prostatan från 1500-talet till mitten av 1800-talet}

Hur hade kunskapsutvecklingen kring prostatan sett ut fram till mitten av 1890talet? Åsikterna går isär huruvida det var Galenos som var den första att beskriva prostatan. Medicinhistorikerna Franz Josef Marx och Axel Karenberg menar i sin studie av ordet prostata att den beskrivning gjord av Herophilius som Galenos återgett inte kan räknas som prostatan eftersom han använde den grekiska pluralformen för prostata (parastatai adenoides) även för sädesblåsorna och sädesledarna. ${ }^{106}$ Helen Valier tolkar dock i sin studie av prostatacancerns historia beskrivningen som den första av prostatan, även om den också innefattar närliggande strukturer som vi idag inte räknar till prostatan. ${ }^{107}$ Harry Shelley menar i sin tur att Herophilius misstog sädesblåsorna för prostatan, ett misstag som kan ha berott på att han dissekerade apor som har en kluven prostata. ${ }^{108}$

Prostatan så som vi känner den idag nämndes för första gången 1536 i en medicinsk text av den venetianske läkaren Niccolò Massa (1485-1569) i Liber Introductorius Anatomiae, men endast i förbigående. Det var först 1538 som Andreas Vesalius (1514-1564), belgisk läkare och anatom, beskrev prostatakörteln och illustrerade med en bild. ${ }^{109}$ Bilder och beskrivningar av prostatan förekom även i hans verk De Humani Corporis Fabricia, som utkom 1543 och blev en av den vetenskapliga revolutionens mest inflytelserika texter. Verket kopierades och kommenterades i andra texter och Helen Valier menar att det gjorde Vesalius text till den första medicinska beskrivning och illustration som gjorde prostatan känd

\footnotetext{
${ }^{106}$ Franz Josef Marx \& Axel Karenberg, "History of the Term Prostate", The Prostate, vol. 69, nr. 2, 2009, s. 209.

107 Valier 2016, s. 21.

108 Shelley 1969, s. 452.

${ }^{109}$ Marx \& Karenberg 2009, s. 209 - 210.
} 
för en bredare krets av läkare. ${ }^{110}$ Men det var 1611 som den danske professorn Caspar Bartholin (1585-1629) gav körteln namnet "prostata". 111

Den rent fysiska avgränsningen av körteln till den struktur vi idag kallar prostatan hade påbörjats under 1500-talet och befästes ytterligare under 1600talet. De agentiella snitten hade gjorts, och de apparater som framförallt använts för att göra detta var läkares ögon och fingrar och de medicinska instrument som använts vid post mortemundersökningar. Det hade skapat ett objekt som var möjligt för den medicinska vetenskapen att studera. Prostatan skildes från de mest närliggande strukturerna, så som sädesblåsorna och sädesledarna, vilka tidigare ingått i beskrivningen, och från sädessträngarna, Cowpers körtlar, urinblåsan och urinröret.

Att på olika sätt avgränsa fysiska delar och strukturer i kroppen och se kroppen som ett arrangemang av dessa delar var inget unikt för avskiljandet av prostatan som ett kunskapsobjekt. Det kännetecknar istället den moderna vetenskapen, där det blev allt viktigare att kartlägga, klassificera och systematisera. ${ }^{112}$ En stor del av kunskapsproduktionen kring prostatan kom att bestå av sådant som klassificeringar av olika förstoringar, statistik över deras förekomst, försök att kartlägga vilka män som drabbades och vilka åldersgrupper och hur stora problemen blev beroende på förstoringens natur.

Det var länge oklart om prostatan var en eller två körtlar. ${ }^{113}$ Prostatans form, som påminner om en persika med två sammanväxta lober, gjorde att det var svårt att avgöra. Dessutom var prostatan hos vissa djur inte sammanväxt som hos människan utan delad i två skilda strukturer. Och många läkare var oense om dess

\footnotetext{
110 Valier 2016, s. 24.

111 Shackley 1999, s. 776.

112 Bondestam 2010, s. 55; Ludmila. J. Jordanova, Nature displayed: gender, science, and medicine 1760 - 1820: essays, Longman, London, 1999.
}

${ }^{113}$ Marx \& Karenberg 2009, s. 210. 
funktion: vissa ansåg att den förfinade sperman som kom från testiklarna, andra trodde att den utvann en vätska ur blodet som gjorde samlag mer njutbart, andra att den producerade en vätska som fuktade och skyddade urinröret och ytterligare andra att den producerade sperma. ${ }^{114}$ Oenigheten påverkade benämningen och länge användes termen prostatae, alltså plural. Det var först runt sekelskiftet $1800 \mathrm{i}$ och med förändrade kunskaper i anatomi och kirurgisk praktik, som körtelns form och uppbyggnad slutligen kunde slås fast. ${ }^{115}$ De agentiella snitten gjordes nu så att prostatan var en körtel (se nedan för en diskussion om prostatan som muskel). Efter detta började ordet användes i singular på engelska. ${ }^{116} \mathrm{I}$ det svenska materialet är det under 1800-talet alltid en körtel som avses, även om stavningen i texter författade på latin ibland är prostatae.

Prostatan började under denna tid att kopplas samman med ett antal symptom som var kända sedan länge. Urinretention, oförmåga att urinera, som i slutet av 1700-talet och början av 1800-talet hade ansetts bero på svaghet och förlamning i blåsmuskulaturen, ansågs nu istället ofta bero på problem med prostatan. ${ }^{117}$ Det kvarstod många oklarheter kring körtelns anatomi och funktion. Vid Svenska Läkaresällskapets sammankomster 1843-1844 diskuterades uppfattningen att prostatan inte omslöt urinröret helt utan endast till tre fjärdedelar. Anatomen Anders Retzius (1796-1860) framförde åsikten att de anatomer som menat att prostatan helt omslöt urinröret inte hade undersökt prostatan under rätt förhållanden, när prostatan inte var förstorad. Kirurger som Jean Zuléma Amussat (1796-1856) och Louis Auguste Mercier (1811-1882) hade istället beskrivit detta korrekt - endast i förstorad form omslöt prostatan hela

\footnotetext{
114 Marx \& Karenberg 2009, s. 210.

115 Ibid, s. 210-211.

116 Ibid, s. 211.

117 Richar Warholm, ”Om prostatahypertrofiens operativa behandling”, Hygiea, band 57, april, 1895, s. 404.
} 
urinröret. Retzius hävdade att det var välkänt att prostatan förändrades under livet och att den tydligt växte till vid högre ålder. ${ }^{118}$

Den så kallade tredje lobens (lobus tertius), mittenlobens eller mitellobens existens diskuterades under hela 1800-talet. Mercier ansåg att den struktur som kirurgen Everard Home (1756-1832) felaktigt kallade mittenloben var mycket liten hos vuxna män, nästan oupptäckbar hos vissa, men hos äldre kunde uppnå en ansenlig storlek. ${ }^{119}$ Borelius hade läst vad bland andra Joseph Griffiths (1863 1945) ${ }^{120}$ hade att säga om lobus tertius och menade att det fanns de som kunnat visa att den bestod av "konstant förekommande accessoriska prostatakörtlar": körtlar som alltid fanns hos vissa personer och som kunde växa till. De fanns precis under

118 "Förhandlingar vid Svenska Läkaresällskapets sammankomster år 1843 - 1844. Den 24 Oktober 1843.", Hygiea, band 6, december, 1844, s. 786.

${ }^{119}$ Louis Auguste Mercier,’Om ett nytt medel att med säkerhet diagnostisera Prostatæ olika deformationer, hvilka blifvit ansedda som vanliga orsaker till retentio et incontinentia urinæ hos äldre männer, af D:r A. Mercier; öfvers. af J. Hörlin (Neue Notizen etc. v. v. Froriep N:o 231, 1839)", Hygiea, band 2, juni, 1840, s. $276-277$.

${ }^{120}$ Joseph Griffiths (1863 - 1945) (i Borelius artikel stavat "Griffits") utbildade sig i Edinburgh och tog sin examen i medicin 1885. Han blev tilldelad en guldmedalj för sin medicine doktorsavhandling 1890 och var under en kort tid kvar i Edinburgh som assistent till professorn i patologi innan han flyttade till den patologiska avdelningen i Cambridge. Han blev senare professor i mänsklig anatomi och undervisade i kirurgi i Cambridge under slutet av 1880-talet. Mellan åren 1898 och 1903 innehade han titeln "Reader in Surgery" vid Addenbrook's Hospital. Han kom senare att avsäga sig denna titel för en professur i kirurgi vid samma sjukhus. Griffiths specialistområden var ben- och ledskador, och urogenitala sjukdomar. 1895 gav han tre Hunterian lectures om testiklarna, och han skrev utförligt om de nedre urinsystemets delar vilket publicerades i fournal of Anatomy and Physiology 1888 - 1896. Walter John O’Connor, British Physiologists 1885 - 1914: A Biographical Dictionary, Manchester University Press, 1991, s. 65 - 66. 


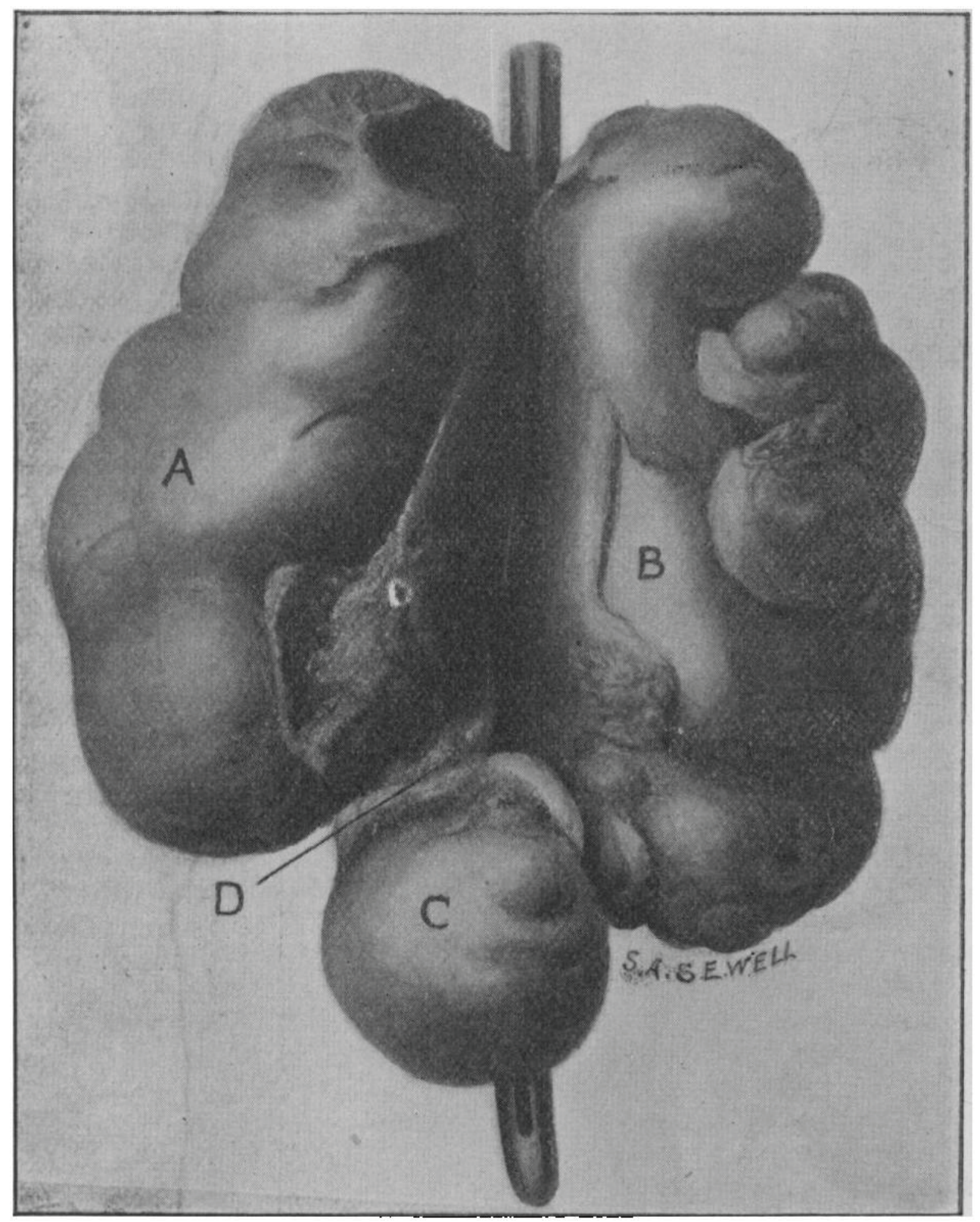

Bilden föreställer en förstorad prostata avlägsnad från en 76-årig patient genom suprapubisk prostatektomi. Bokstäverna A och B markerar de två sidoloberna och $\mathrm{C}$ mittenloben. Källa: Peter Johnston Freyer, "A Clinical Lecture On A Further Series Of Cases Of Total Extirpation Of The Prostate For Radical Cure Of Enlargement Of That Organ", The British Medical Fournal, vol. 1, nr. 2144, feb. 1, 1902, s. 252. 
huden och kunde som resten av prostatan förstoras vid prostatahypertrofi, och då uppstod en tredje lob. ${ }^{121}$ Den tredje loben beskrevs som att den fanns på”baksidan” av prostatan där de två sidoloberna möts. Det var en del av prostatan som relativt ofta drabbades av förstoring och som redan i början av 1800-talet hade identifierats som en speciellt besvärlig del när det gällde prostatahypertrofi - Borelius konstaterade att det fanns i ungefär hälften av de fall han undersökte. ${ }^{122}$ En förstoring av denna del av prostatan medförde ofta urineringsproblem i och med hur den tryckte på urinröret och upp mot blåsans botten. ${ }^{123}$ Kunskapsproduktionen kring prostatan, framförallt genom post mortemundersökningar, hade resulterat i skapandet av ett kunskapsobjekt att studera, men detta objekts egenskaper, funktion och anatomi var fortfarande omdiskuterade.

\section{Prostatan frän 1800-talets mitt fram till 1890-talet}

Kunskapsproduktionen kring prostatan, framförallt genom post mortemundersökningar, hade skapat ett kunskapsobjekt att studera, men ännu vid 1800-talets mitt var prostatans anatomi eller funktion inte fullständigt klarlagd. Mot slutet av 1800-talet gick meningarna framförallt isär angående om prostatan var en körtel eller en muskel, och om den hade någonting att göra med urinering eller om den endast var en sexuell körtel.

Den engelske kirurgen Reginald Harrison (1837-1908) ${ }^{124}$ var den främste bland dem som förespråkade teorin att prostatan var mer en muskel än en körtel

121 Borelius 1897a, s. 252.

122 Ibid.

${ }^{123}$ Mercier 1840, s. 276 - 277. För tredje lobens inverkan på prostatahypertrofi se även Warholm 1895, s. 404.

${ }^{124}$ Reginald Harrison (1837 - 1908) var en engelsk läkare som under sitt liv innehade ett stort antal anställningar som kirurg vid olika sjukhus i England, först i Liverpool och senare i London. Han var bland annat kirurg vid St Peter's Hospital for Stone and other Urinary Diseases 1889 
och fyllde en viktig funktion vid urinering, och han var också en av de sista. ${ }^{125}$ Han hade under en stor del av 1800-talet varit en auktoritet på området problem med urinvägarna, och han menade att om prostatan var mer som en muskel var det inte konstigt att den kunde bli förstorad, som vilken annan muskel som helst. Han avvisade vidare att prostatan skulle ha någon som helst viktig sexuell funktion. Som bevis anförde han att han hade sett prostator som varit helt förstörda av varbölder utan att det påverkade potensen. ${ }^{126}$

Harrison resonerade alltså kring prostatans funktion utifrån hur påverkad den sexuella funktionen blev när det gällde erektion, ejakulation och förmågan att genomföra ett samlag vid till exempel prostatahypertrofi. Om prostatan var en sexuell körtel borde väl symptomen främst drabba dessa funktioner, och inte urineringsförmågan? Harrisons egna erfarenheter av att operera och behandla

- 1905. Han var också medlem av flera olika sällskap och innehade viktiga positioner i flera, bland annat president för the Medical Society of London 1890, och utsedd till Hunterian Professor of Surgery and Pathology at the Royal College of Surgeons of England 1891. Under sin tid som president för Liverpool Medical Institution under 1880-talet förespråkade han införandet av hästdragna ambulanser i staden. Harrison reste även mycket till Amerika och var hedersmedlem i American Surgical Association. Han var under hela sitt verksamma liv intresserad av, och känd som specialist på, de sjukdomar som drabbar de manliga uro-genitala organen. 1878 publicerade han en volym Clinical Lectures on stricture of the urethra, som gavs ut i en andra upplaga 1880 under namnet Disorders of the Urinary Organs. Denna publication placerade Harrison bland de främsta kirurgerna på området. "Reginald Harrison, Fr. C. S. Eng", The British Medical Fournal, vol. 1, nr. 2462, mar. 7, 1908, s. 601-603.

125 Reginald Harrison, "Lettsomian Lectures on some Points in the Surgery of the Urinary Organs", The British Medical fournal, vol. 1, nr. 1412, jan. 21, 1888, s. 118; Harrison fick visst stöd för muskelteorin av bland annat James MacMunn, "The Functions of the Prostate", The British Medical Fournal, vol. 2, nr. 1649, aug. 6, 1892, s. 328.

${ }^{126}$ Fredrik Ramm, "Kastration ved Prostatahypertrofi”, tilläggsskrift till Norsk Magazin for Legervidenskaben, Maj 1896, Kristiania Det Steenske Bogtrykkeri 1896, s. 34; William White, "The Present Position of the Surgery of the Hypertrophied Prostate", Annals of Surgery, vol. 18, juli/december, 1893, s. 154. 
prostataproblem visade att det varken kastrerade patienten eller påverkade reproduktionsförmågan. ${ }^{127}$ Prostatans funktion var enligt Harrison uteslutande att kontrollera och stödja urinflödet genom att fungera som en slutarmuskel till urinblåsan. ${ }^{128}$ Den "apparat", den gränsdragande praktik, som skapade prostatan som ett kunskapsobjekt var för Harrison främst de observationer han gjorde av symptom och bieffekter hos patienterna. De gjorde prostatan främst till en muskel. Om den även hade någon form av körtelfunktion gjorde samma "apparat" denna till en sekundär funktion till slutarmuskelfunktionen. ${ }^{129}$

Harrison fick medhåll av en läkare som menade att det fanns kopplingar mellan det muskulära skiktet hos prostatan och urinblåsan, att prostatan fungerade som ett stöd för urinblåsan och att man kanske borde tänka sig att urinretention kunde bero på andra orsaker än blockering orsakad av en förstorad prostata. Urinretention skulle då kunna bero på att det muskulära stödet för urinblåsan försvagades med åren eller att det av okänd orsak förslappades hos vissa yngre män, och att detta i sin tur orsakade en förslappning och degeneration av blåsan som vållade urineringsbesvären. ${ }^{130}$

Mot denna hypotes invände andra läkare och kirurger bland annat att kvinnor, eunucker och prepubertala pojkar, som ännu inte hade en utvecklad prostata, inte hade några problem att urinera utan stöd från prostatan. Denna frånvaro av en prostata minskade inte heller kraften i urinstrålen. ${ }^{131}$ I stället för att som Harrison argumentera för att prostatans påverkan på urineringsförmågan visade på dess roll i urineringsfunktionen, menade de att den sjuka prostatans

127 Harrison 1888, s. 119.

128 Harrison 1888, s. 118; Ramm 1896, s. 34; White 1893, s. 154.

129 Harrison 1888, s. 118.

130 MacMunn 1892, s. 328.

${ }^{131}$ Ramm 1896, s. 34 - 35; C. W. Mansell Moullin, "Lectures on the Operative Treatment of Enlargement of the Prostate", The Lancet, vol. 139, nr. 3588 (ursprungligen publicerad som volym 1, nummer 3588) june 4, 1892a, s. 1229; Mansell Moullin 1895b, s. 114. 
påverkan på urineringsfunktionen inte hade något att göra med den friska prostatans funktion. ${ }^{132}$ Dessa läkares förklaringar till förekomsten av muskler i prostatan var att prostatan producerade ett sekret som skyddade spermierna och att den muskulära funktionen var till för att sekretet skulle tömmas ut i urinröret. 133 Prostatan behöll enligt dessa läkare sin rent sexuella funktion hela livet och utvecklades i embryot från de wolffska gångarna. ${ }^{134}$ De embryologiska och komparativa studier som utförts för att utröna varifrån och hur prostatan utvecklades visade en samhörighet med det genitala systemet, inte urinsystemet. Dessutom skrumpnade prostatan bort hos hingstar som kastrerats, vilket visade på en koppling mellan testiklarna och prostatan och ytterligare stärkte kopplingen till det sexuella systemet. ${ }^{135}$

Borelius, som läst både Harrison och hans kritiker, menade precis som de flesta andra kirurger under perioden att prostatan främst var en sexuell körtel och inte en muskel. Han bedömde Harrisons muskelteori som "knappast hållbar". ${ }^{136}$ Enligt Harrison kunde prostatan förstoras som en kompensatorisk effekt vid

132 Ramm 1896, s. 34 - 35; Mansell Moullin 1892a, s. 1229; Mansell Moullin 1896a, s. 114. 133 White 1893, s. 155; "The structure and function of the prostate gland", The Lancet vol. 154, nr. 3978 (ursprungligen publicerad som volym 2, nr. 3978), nov. 25, 1899, s. 1455. Detta är ett referat av en originalartikel publicerad i Archive für Anatomie und Physiologie oktober 1899 av George Walker; Mansell Moullin 1896a, s. 114; Joseph Griffiths, "Three Lectures Upon the Testes, Lecture I", The Lancet, vol. 145, nr. 3735 (ursprungligen publicerad som volym 1, nr. 3735) mars 30, 1895b, s. 793.

${ }^{134}$ Döpta efter Caspar Friedrich Wolff. De wolffska gångarna är embryonala strukturer som utvecklas under fostrets sjätte vecka och ur vilka sädesledare, bitestiklar och sädesblåsor sedan utvecklas. De Wolffska gångarna tillbakabildas nästan helt hos de foster som utvecklas till kvinnor. Uppslagsord wolffska gångar https://www.ne.se [sidan besökt 2019-10-09].

135 Mansell Moullin 1892a, s. 1229; Charles William Mansell Moullin, ”The Pathology of enlargement of the prostate", The Lancet, vol. 144, nr. 3712 (ursprungligen publicerad som volym 2, nr. 3712) okt. 20, 1894b, s. 908; White 1893, s. 155.

136 Borelius 1897a, s. 268. 
sjukliga förändringar i prostatan, precis som hjärtat kunde förstoras vid sjukliga förändringar i cirkulationsapparaten. Borelius invändning mot detta var att prostatahypertrofi anatomiskt inte handlade om en förstoring av muskulaturen i prostatan. Dessutom var funktionen hos muskulaturen i prostatan inte kopplad till blåsan eller blåsans slutmuskler. ${ }^{137}$ Avslutningsvis konstaterade Borelius: "Prostatas muskulatur torde hafva till funktion att (vid ejakulation) med samlad kraft kasta ut prostatasekretet i uretra: hör således till genitalapparaten." ${ }^{138}$ När Borelius argumenterade på detta sätt talade han om muskler, och det rådde inget tvivel om att prostatan delvis bestod av muskler. De som menade att prostatan var en körtel hävdade att den glatta muskulatur som fanns i prostatan inte hade den funktion Harrison ville tillskriva den, och framförallt att den inte gjorde prostatan till en muskel.

Trots att Harrison argumenterade för en annan funktion hos prostatan hade han gjort samma agentiella snitt för prostatan som kunskapsobjekt. Prostatan är omgiven av ligament och muskler varav vissa sträcker sig upp mot urinblåsan, och Harrison skiljer dem från prostatan på precis samma sätt som andra samtida läkare. Teorin att prostatan främst var en muskel och inte en sexuell körtel tycks inte ha påverkat hur den rent anatomiskt skapades som ett kunskapsobjekt.

Mot slutet av 1800-talet fanns det alltså två parallella hypoteser och vetenskapliga berättelser om vad prostatan framförallt var, en muskel eller en körtel. Båda gjorde samma agentiella snitt när det gällde att avgränsa prostatan från omliggande strukturer och båda identifierade muskelvävnad och körtelvävnad i prostatan. Det som skilde dem åt var hur de förklarade prostatans placering i kroppen och förekomsten av muskelvävnad och körtelvävnad och hur de tolkade symptomen vid prostatahypertrofi. Harrison såg prostatans placering, förekomsten av muskler och urineringsproblemen vid förstoring som bevis för att

137 Borelius 1897a, s. 268.

138 Ibid. 
prostatan tillhörde urinsystemet och var en muskel. De läkare som hade en annan uppfattning och presenterade egna teorier om prostatan menade att prostatans placering liksom förekomsten av muskelvävnad och körtelvävnad hade med dess sexuella funktion att göra. I deras berättelse är prostatan istället en körtel som bildar ett sekret som blandas med spermierna från testiklarna, därav placeringen. Muskelvävnadens roll i prostatan är att transportera detta sekret ut i den del av urinröret som går genom prostatan och där blandas med spermierna som kom via sädesledarna in i urinröret. De två berättelserna utgick från samma förutsättningar men kom fram till helt olika tolkningar.

Harrisons vetenskapliga berättelse om prostatan hade i slutet av 1800-talet nästan helt förlorat sin trovärdighet. Den vetenskapliga debatten hade producerat en annan kunskap om prostatan, att den var en sexuell körtel, och bland de absolut flesta läkare och kirurger rådde konsensus om att det var den korrekta beskrivningen. Det som framförallt hänt i debatten om prostatan var att Harrisons teori hade mött prostatans materialitet när den berättelse han försökte framföra på allt fler punkter stred mot de observationer som gjordes av prostatans funktion. För att tala med Barad: i den process där ett kunskapsobjekt blir till räcker det inte med att säga att något är på ett visst sätt, utan förklaringar måste ta hänsyn till både diskursiva och materiella begränsningar. Vilka berättelser som helst om världen duger inte och de observationer som gjorts fick samtiden att bedöma Harrisons berättelse som ohållbar.

Närmare bestämt motsades Harrisons teori om att prostatan hade en stödoch knipfunktion för urineringen av att kvinnor, eunucker, prepubertala pojkar och andra som saknade en utvecklad prostata ändå klarade av att hålla urin i blåsan. Flera läkare och kirurger hade kunnat visa att den muskelvävnad som fanns i prostatan inte hade den funktion Harrison hävdat. Harrison hade inte heller övertygande kunnat visa att de symptom som uppträdde vid 
prostatahypertrofi, vilka främst hade med urineringsfunktionen att göra, bevisade att prostatan måste tillhöra urinorganen. ${ }^{139}$

Harrisons berättelse fick vika undan för en annan berättelse som bättre stämde överens med de observationer av prostatans materialitet som gjordes av andra läkare. I intra-aktion mellan läkare, apparater och prostatan hade kunskapen om kunskapsobjektet prostatan förändrats. Vissa funktioner blev möjliga att tillskriva prostatan och andra omöjliga. Harrison fortsatte dock att argumentera för muskelteorin. Enligt honom var prostatan ett "sammansatt" organ med två funktioner, varav den sekretbildande funktionen var sekundär och relativt oviktig. ${ }^{140}$

\section{Prostatan under senare delen av 1890-talet}

Under den senare delen av 1890-talet var diskussionen om prostatan som körtel eller muskel mer eller mindre avslutad. Det betydde dock inte att läkare och kirurger ansåg sig veta allt om prostatan. Prostatan framstod som en svårgripbar körtel som gömde sig inne i kroppen och dess form, funktion och etymologi diskuterades i slutet av 1800-talet. Många frågor var fortfarande outredda och mycket osäkerhet kvarstod om prostatans funktion, sjukdomar och relation till andra körtlar, som testiklarna. En läkare skrev så sent som 1895 att "none of us know the normal shape of the prostate, for it varies with each decade [of life] and with each individual". ${ }^{141}$ Han menade att många läkare bortsåg från det faktum att prostatans form kändes annorlunda i konturen vid rektal undersökning beroende på faktorer som undersökningsposition och vaskulär utvidgning. ${ }^{142}$

\footnotetext{
${ }^{139}$ Mansell Moullin 1892a, s. 1229; Mansell Moullin 1896a, s. 114.

140 Reginald Harrison, "Observations on the Pathology of Enlarged or Hypertrophied Prostate", The British Medical Fournal, vol. 2, nr. 1826, dec. 28, 1895, s. 1605.

${ }^{141}$ Fenwick 1895a, s. 529.

142 Ibid.
} 
Dessutom stod det klart att prostatan ändrade storlek med åldern hos nästan alla män, oavsett om de drabbades av sjukliga förändringar eller inte.

Borelius tog sig an även frågan om prostatans normala anatomi och funktion. I den omfattande studie av prostatan som han rapporterade om i sin artikelserie i Hygiea framgår att Borelius inte nöjde sig med att läsa de internationella auktoriteterna på området. ${ }^{143}$ Han bestämde sig för att utföra ett antal egna observationer och experiment och samla in både egna preparat från avlidna patienter och preparat från andra läkare. Den histologiska institutionen i Uppsala hade ett antal preparat av prostator, och som läkare hade Borelius tillgång till prostator som han själv avlägsnade vid obduktioner. Post mortemundersökningar fortsatte att vara en av de viktigaste praktikerna för att göra prostatan till ett kunskapsobjekt. Antalet friska prostator som Borelius hade att tillgå var dock inte stort, närmare bestämt två från avlidna patienter och sex museipreparat. ${ }^{144}$ Han lät sig inte nedslås av detta utan genomförde mikroskopiska studier av de preparat och prostator han hade tillgång till.

Borelius noterade betydande förändringar i prostatans struktur som uppstod med åren även hos personer som inte drabbats av prostatahypertrofi. Dessa fynd hade han stöd för i den internationella litteraturen. ${ }^{145}$ Det tycktes alltså vara så att prostatan alltid genomgick delvisa atrofiska, hypertrofiska och inflammatoriska strukturella förändringar med stigande ålder, även om den inte förstorades. Borelius gick noggrant igenom alla de strukturella skillnader han kunde se i mikroskopet mellan prostator från yngre män och från äldre. ${ }^{146}$

143 Borelius 1897a, s. 223 - 288; Borelius 1897b, s. 591 - 644; Jaques Borelius, "Bidrag till den s.k. prostatahypertrofiens patologi och terapi”, Del 3, Hygiea, band 59, del 2, juli, 1897c, s. 1 46.

${ }^{144}$ Borelius 1897a, s. 258.

145 Till exempel Lanouis hade konstaterat liknande förändringar vid sina undersökningar. Borelius 1897a, s. $266-267$.

146 Ibid. 
En viktig del av den vetenskapliga berättelsen om prostatans normala och sjukliga anatomi handlade om att se olika strukturer i mikroskopet och lyckas identifiera dem korrekt enligt samtidens uppfattning. Precis som muskelvävnad hade hittats i prostatan med hjälp av mikroskopet så hittade Borelius samt bland andra den franske kirurgen Pierre-Émile Launois (1856 - 1914) även tecken på atrofi, hypertrofi, inflammation och strukturella förändringar; mängden muskelvävnad, körtelvävnad och bindväv tycktes variera med åren och vid förstoring. ${ }^{147}$ Den förförståelse som fanns om strukturerna som kunde ses i mikroskopet skapade, i intra-aktion med mikroskopet och läkaren, den kunskap som producerades genom praktiken att använda mikroskop. Vid dessa mikroskopiska studier kunde Borelius se de lobuli som det tidiga 1800-talets auktoriteter på prostatan, exempelvis Alfred Velpeau $(1795-1867)^{148}$ och Sir Henry Thompson $(1820-1904)^{149}$, hade

147 Borelius 1897a, s. 266 - 268. Pierre-Émile Launois var en fransk kirurg som studerade i Reims för att sedan fortsätta sina studier i Paris. Han tog sin doktorstitel 1885 och blev professor i histologi 1898. Mest känd är Lanuois för sina studier av hypofysen. Pierre-Émile Launois http://www.whonamedit.com/doctor.cfm/777.html [sidan besökt 2019-10-16].

I oktober 1894 publicerade Lanouis "De l'Atrophie de la prostate, de la castration dans l'hypertrophie de la prostate; étude embryologique, tératologique, anatomique, clinique et expérimentale" i Annales des Maladies des Organes génito-urinaire. En artikel som ofta refererades av svenska och angloamerikanska läkare i materialet.

148 Alfred-Armand-Louis-Marie Velpeau (1795 - 1867) var en fransk läkare och kirurg som blev medicine doktor 1823 och professor i kirurgi 1834 i Paris. Han innehade denna position till sin död. Velpeau publicerade under sitt liv mer än 340 titlar på bland andra ämnen som kirurgi, embryologi, anatomi och obstetrik och var en av sin tids främsta kirurger. Nordisk Familjebok. Uggleupplagan, andra utgåvan http://runeberg.org/nfck/0575.html, [sidan besökt 2019-10-20], WorldCat Identities http://www.worldcat.org/identities/lccn-n86-844455/, [sidan besökt 2019-10-20].

149 Henry Thompson $(1820$ - 1904) engelsk kirurg som bland annat blev professor i klinisk kirurgi 1866, professor of surgery and pathology in the Royal College of Surgeons 1884. Han studerade en period i Paris för Civalier för att lära sig hans operationsmetoder. Thompson var specialiserad på urogenital kirurgi, speciellt urinblåsan, och genomförde bland annat en litotomi 
betecknat som myom eller tumörer och som under en period ansågs vara avgörande för att förstå förstoringen av körteln. ${ }^{150} \mathrm{Jag}$ återkommer i nästa kapitel till denna tanke om förstoringen som myom eller tumörer och den nya hypotesen som utvecklades om dessa.

Läkare fortsatte att genomföra studier och experiment för att förstå prostatans struktur och funktion. År 1899, i mitten av undersökningsperioden, rapporterade The Lancet om dr George Walker (1869-1937) vid Johns Hopkins Hospital i Baltimore som försökte reda ut frågan en gång för alla genom att studera prostator från människor, hundar, katter, grisar, mullvadar, igelkottar, oxar och hamstrar. En av slutsatserna av denna omfattande studie var att prostatans muskler inte kunde fungera som en slutarmuskel till urinblåsan, utan endast dra samman prostatan. ${ }^{151}$

Walker hade sammanfattat de hypoteser kring prostatan som förts fram av andra läkare, bland annat att prostatasekretet tillsammans med ett sekret från sädesblåsorna förhindrade sperman från att läcka ut när den hade sprutats in i vaginan, att den stora mängden muskler i körteln tydde på att den hjälpte till vid utdrivandet av sperman och att prostatans funktion fortfarande var okänd. ${ }^{152}$

(krossade och avlägsnande av stenar i urinblåsan) på kung Leopold I av Belgien och utnämndes efter detta till kunglig kirurg, något han fortsatte vara även under Leopold II. Thompson genomförde även en liknande operation på Napolenon III, som dock avled i uremi fyra dagar efter operationen. Thompson var också med och grundade the Cremation Society of Great Britain och arbetade för att få bort mycket av motståndet mot kremering. Thompson vann också flera utmärkelser för sina texter om olika urologiska sjukdomar och deras behandlingar. Bland annat vann han The Jacksonian Prize Essay for 1852 med sin text The Pathology and Treatment of Stricture of the Urethra and Urinary Fistule, och The Jacksonian Prize for the Year 1860 med sin text On the Healthy and Morbid Anatomy of the Prostate Gland. "Sir Henry Thompson, Bart., M.B., F.R.C.S”, The British Medical Fournal, vol. 1. nr. 2260, april 23,1904, s. 991 - 993.

150 Borelius 1897a, s. 267.

151 “The structure..." 1899, s. 1455.

152 Ibid. 
Walker hade dock lyckats observera att spermierna knappt rörde sig i någon del av det sexuella systemet från testiklarna fram till prostatan. När de hade blandats med sekretet från prostatan blev de däremot livliga, vilket överensstämde med rapporter från andra läkares observationer. ${ }^{153}$ Walkers studie tycks ha blivit den sista spiken i kistan för Harrisons muskelteori. Samtidigt lämnade studien ett stort antal frågor obesvarade när det gällde prostatans och prostatasekretets funktion.

Att teorierna om prostatans funktion, och framförallt om prostatahypertrofins uppkomst, gick isär medförde att det användes ett antal behandlingsmetoder mot denna åkomma. Hur läkarna såg på prostatan fick konsekvenser för vilken berättelse om prostatahypertrofin och dess behandling de lade fram. Olika behandlingsmetoder krävde att prostatan kunde visas ha vissa funktioner och inte andra. Framförallt krävde behandlingsmetoden kastrering att prostatan inte var en del av urinsystemet utan av det sexuella systemet.

Intra-aktionen mellan läkarna, apparaterna och prostatan producerade inte alltid samma kunskap. Skillnader i förförståelse, i de apparater som användes och i hur resultaten från denna praktik tolkades, och i hur prostatans materialitet påverkade denna intra-aktion, producerade olika kunskap om prostatans funktion.

\section{Vad var prostatahypertrofi?}

Prostatahypertrofi var en sjukdom som var välkänd bland läkare i slutet av 1800talet och som drabbade många män, men det var endast ett mindre antal som fick besvär och ännu färre som fick allvarliga problem. De frågetecken som fanns kring prostatan som körtel gjorde det svårt att förstå en av dess vanligaste sjukdomar.

153 “The structure..." 1899, s. 1455. 
När William White (1850-1916) ${ }^{154}$ och Fredrik Ramm (1855-1932)155 1893 föreslog kastrering som behandlingsmetod hade de endast hypoteser som skulle kunna förklara vad prostatahypertrofi var. "Den frågan lärer tillsvidare få betraktas som olöst”, skrev Borelius när han fyra år senare genomförde sin omfattande studie i ämnet. ${ }^{156}$ Så länge läkarvetenskapen var okunnig om prostatahypertrofins etiologi, alltså dess orsak och uppkomst, var frågan svårlöst, enligt Borelius. ${ }^{157}$

Sjukdomen var också besvärlig eftersom det inte fanns någon typisk eller enhetlig klinisk bild. Symptomen och sjukdomsförloppet kunde skilja sig så mycket åt att Borelius menade att "man a priori leds till den misstanken, att det patologiska underlaget icke alltid kan vara detsamma". ${ }^{158}$ De tillstånd som

${ }^{154}$ James William White (1850 - 1916) var en amerikansk kirurg från Philadelphia. År 1871 tog han sin medicine doktorsexamen och filosofie doktorsexamen och blev med tiden bland annat professor i urogenital kirurgi, klinisk kirurgi och sedan John Rhea Barton Professor of Surgery. Han undervisade under 40 år vid Dr. Hays Agnews lärosäte i Philadelphia. White var även en av redaktörerna för Annals of Surgery och bidrog under sitt liv med ett stort antal publikationer i formen av artiklar och kirurgiska handböcker på diverse medicinska områden. ’James William White", The British Medical fournal, vol. 1 nr. 2890, maj 20, 1916, s. 743.

${ }^{155}$ Fredrik Gottlieb Ramm (1855 - 1932) var en norsk läkare och kirurg. Han var den förste att utföra en kastrering på mänsklig patient för att bota/behandla prostatahypertrofi. Han tog medicinsk kandidatexamen 1881 och arbetade som fiskeriläkare i Lofoten 1881. Mellan åren 1884-1890 var han praktiserande läkare i USA bland annat i Minnesota och Dakota. 1890 flyttade han tillbaka till Norge och blev praktiserande läkare i Stavanger. Ramm blev året efter reservläkare vid Rikshospitalets kirurgavdelning och arbetade som sjukhusläkare i Tromsö från 1894 fram till 1897 när han blev överläkare vid Akers Sjukhus i Oslo. En tjänst som han behöll fram till 1912. Zinow Genealogy Website, Fredrik Gottlieb Ramm, http://zinow.no/tngfiles1010/getperson.php?personID=I6183\&tree=treelzinow [sidan besökt 2016-10-20].

156 Borelius 1897a, s. 268.

157 Ibid

158 Borelius 1897b, s. 591. 
betecknades som prostatahypertrofi hade därtill så skiftande orsaker att det måste röra sig om olika sjukdomar. Borelius hade troligtvis helt rätt i att alla tillstånden inte egentligen var "sann hypertrofi", alltså en förstoring av prostatan som berodde på tillväxten av godartade adenom, förändringar i körtelvävnaden och tillväxt av bindväv. För de läkare som intresserade sig för det manliga urogenitalasystemets sjukdomar var prostatahypertrofins etiologi en mycket viktig fråga.

Henry Thompson hade 1875 konstaterat att denna högst allmänna åkomma "börjar som bekant vid 55 eller 60 års ålder med oförmåga att fullt tömma blåsan”. ${ }^{159}$ Borelius påpekade att den även kunde börja tidigare i livet. Framstående kirurger på området hade noterat prostatahypertrofi hos barn, unga män och hos vuxna mellan 25 och 37 år. ${ }^{160}$ Enligt Borelius kunde prostatahypertrofi därför inte endast kategoriseras som en senil förändring. Problemet med att se det som en förändring kopplad till åldrande var att sådana förändringar snarare tenderar att innebära atrofi, att ett organ skrumpnar, enligt Borelius. Hos de äldre patienter som inte drabbats av förstoring var det just en atrofi av prostatan som kunde observeras. Borelius kategoriserade därför prostatahypertrofi som en sjuklig förändring, inte en senil. ${ }^{161}$

159 "Henry Thompson: Om de kirurgiska medel, som kunna användas för att giva lindring åt patienter med långt framskriden affektion af prostata", Hygiea, band 37, februari, 1875, s. 94; Även refererat i Warholm 1895, s. 403.

${ }^{160}$ Borelius 1897a, s. 254. Mansell Moullin var en av flera läkare som under tidigt 1890-tal började rapportera om att hypertrofi uppstod mycket tidigare hos vissa män än man tidigare trott att det kunde göra. Själv rapporterar han om ett fall där han opererat en 27-åring man som redan då lidit av hypertrofi av prostatan under några år. Han menade därför att det inte var åldern som orsakade hypertrofin av organet. Han såg alltså ingen relation mellan patientens ålder och prostatahypertrofi. Han menade också att majoriteten av alla män aldrig drabbades av en förstoring av prostatan. Mansell Moullin 1892a, s. 1229; Mansell Moullin 1896a, s. 115 .

161 Borelius 1897a, s. 268. 
Den vetenskapliga berättelse som Borelius återger i sin artikel handlar om prostatan som ett organ vilket i normala fall atrofierar med åldern men kan drabbas av ett tillstånd, prostatahypertrofi, som gör att den istället förstoras och orsakar problem för patienten. Borelius baserade dessa slutsatser framförallt på observationer, gjorda av honom själv men även av andra läkare, där vissa vävnadsförändringar tolkades som atrofiering och andra som förstoring. Avgörande för Borelius berättelse om prostatahypertrofi var alltså möjligheten att kunna genomföra post mortemundersökningar av prostator, observera dem med cystoskop och känna på dem med fingrarna hos levande patienter. Även obduktionsprotokoll och att ha tillgång till andras observationer publicerade i böcker och artiklar var viktigt för kunskapsproduktionen. Dessa var några av de absolut viktigaste praktikerna och apparaterna för att göra prostatahypertrofi till ett kunskapsobjekt. Läkare och kirurger ägnade sig åt en egen kunskapsproduktion kring prostatan och prostatahypertrofi, men kunskapsproduktionen och konstruktionen av prostatahypertrofi som ett avgränsat tillstånd byggde vid denna tid mycket på samverkan med andra läkare och kirurger.

Medicinen hade, liksom andra vetenskaper lämnat den tid bakom sig då enskilda individer bedrev experiment och forskning ensamma utan speciellt mycket kontakt med andra eller utbyte av idéer. Det hade blivit allt lättare att ha kontakt med andra inte bara brevledes utan vid besök eller sammankomster där man träffades för att avhandla olika frågor och hålla sig a jour med de färskaste forskningsresultaten. ${ }^{162}$ Det dröjde till exempel inte lång tid mellan att något

162 Till exempel rapporterar Borelius i slutet av en av de artiklar som publicerades i Hygiea om resultatet av den undersökning Boleslas Motz utfört vid Guyons klinik. Dessa hade publicerats i boken Contribution á l'étude de la structure histologique de l'hypertrophie de la Prostate: introduction au traitement de l'hypertrophie de la prostate par les opérations sur l'appareil testiculaire, (Thèse de Paris), Paris: Henri Jouve, 1896. Den 3 december 1896 diskuterades denna i Paris, men Borelius hade hunnit skicka in sin artikel till Hygiea i början av december, och därför inte kunnat 
diskuterades i Paris och att en svensk läkare läst denna avhandling och utlovade ett sammandrag som skulle publiceras i Hygiea. Och detta var inte unikt för kastreringsdebatten under 1890-talet. Idéhistorikern Annelie Drakman har i sin avhandling När kroppen slöt sig och blev fast visat att Svenska provincialläkarföreningens tidskrift Eira publicerade ett antal artiklar om smittoöverföring från skadedjur och insekter vilka även de följde den senaste forskningen i London, Paris och Berlin. ${ }^{163}$

Överlag förändrades förutsättningarna för medicinen i Europa och USA under 1800-talet på många områden. Nu började anställningar för heltidsforskning och undervisning växta fram. I och med detta byggdes också institutioner med utrustning för forskning och undervisning. Och för kommunikation mella läkare och kirurger grundades medicinska tidskrifter och sällskap. ${ }^{164}$ Ångfartyg och tåg gjorde det lättare och snabbare att resa. ${ }^{165}$ Allt detta möjliggjorde en uteckling av medicinen där kontakterna mellan framförallt Europa och USA blev fler och medicinen började röra sig mot en större enhetlighet. ${ }^{166} 1897$ skrev en framstående amerikansk kirurg:

referera denna. Enligt Borelius avhandlade Motz liknande frågor som han själv tagit upp i sin artikel och boken innehöll "rätt mycket af intresse". Borelius 1897a, s. 288.

163 Annelie Drakman, När kroppen slöt sig och blev fast: varför åderlåtning, miasmateori och klimatmedicin övergavs vid 1800-talets mitt, (Diss.) Uppsala: Uppsala universitet, 2018, s. 154.

${ }^{164}$ E. M. Tansey, ”The Physiological Tradition” i Bynum, W. F. \& Porter, Roy (red.), Companion encyclopedia of the history of medicine. Vol. 1, Routledge, London, 1993, s. $126-$ 128, $132-138$.

165 Thomas Schlich, "One and the Same the World Over": The International Culture of Surgical Exchange in an Age of Globalization, 1870 - 1914", Fournal of the History of Medicine and Allied Sciences, vol. 71, nr. 3, 2016, s. 252.

166 Tansey 1993, s. 126. För andra utbyten och påverkan mellan Frankrike och USA se till exempel John Harley Warner, Against the Spirit of System: The French Impulse in Nineteenth-Century American Medicine, Princeton University Press, Princeton, NJ, 1998; Peter Cryle, "Vaginismus: 
But surgery is one and the same the world over. Whether in the frozen north or under the equator, in civilized America or barbaric Africa, be the patient white Caucasian, swarthy Negro, red Indian or yellow Malay, the same accidents and diseases assail him, the same remedies save him, identical operations cure him: a new remedy discovered in Japan is equally efficacious in Philadelphia; a new operation devised in America is equally applicable in Egypt. ${ }^{167}$

Denna internationalisering framträder i Borelius artiklar. Han baserade tydligt sina slutsatser på, och jämförde sina resultat och observationer med, tidens mest inflytelserika kirurger, och han hade möjlighet att ta del av deras texter så fort de publicerades. Han refererar och citerar alltid originaltexterna på de olika språken. ${ }^{168}$ I likhet med läkare från andra länder publicerade han översiktsartiklar där resultaten från läkare i stora delar av Europa och USA sammanfattades. ${ }^{169}$ Den medicinska kunskapen om prostatahypertrofi kunde under det sista decenniet före sekelskiftet 1900 börja ses som allt mer om inte global så i alla fall internationell. Det innebar dock inte att det rådde konsensus om vad prostatahypertrofi var och hur den bäst behandlades. Diskussionerna var internationella men vad som sågs som etablerad kunskap och lämplig behandling varierade både mellan enskilda kirurger och mellan länder.

Borelius gick noggrant tillväga för att besvara frågan om prostatahypertrofins orsaker och anatomiska förändringar. I sin artikelserie 1897 började han med att i detalj redogöra för nitton museipreparat som han fătt tillgång till av professorerna Odenius och Key. Sju av dem var avbildade för att visa på vilka sätt

A Franco-American Story", Fournal of the History of Medicine and Allied Sciences, vol. 67, nr. 1, 2010, s. $71-93$.

167 Citerad i Schlich 2016, s. 247.

168 Även Fredrik Ramm citerar i sin artikel från 1896 originaltexter på franska, tyska och engelska.

${ }^{169}$ Borelius 1897b, s. $594-595$. 
prostatan kunde förstoras. Borelius konstaterade dock att detta urval kanske inte var så representativt eftersom prostatorna av olika anledningar hade förvarats på museer, där man tenderade att bevara de preparat som hade mer utpräglade förändringar och mer synliga förändringar. För att få mer rättvisande resultat studerade Borelius därför också de samlade obduktionsprotokollen från institutionen i Uppsala, som sträckte sig från 1860 till 1895. ${ }^{170}$ Tyvärr var de inte alltid så utförliga när det gällde noteringar om prostatahypertrofi eftersom obduktionerna ofta hade utförts av någon annan orsak och en förstorad prostata bara noterades i förbigående. I dessa 1851 protokoll fanns 89 fall av prostatahypertrofi upptagna, och Borelius konstaterade att beskrivningarna av dem gav en bild av att en förstorad prostata kunde ha mycket olika former. Beroende på vilket slags form förstoringen av prostatan tagit valde man olika kirurgiska ingrepp, men man avstod också från kirurgiska ingrepp när det fanns tidigare erfarenhet av att de inte hjälpte vid dessa former av förstoringar. ${ }^{171}$

\section{Problemen med diagnostisering}

Det var inte alltid helt lätt att diagnostisera prostatahypertrofi eftersom det fanns ett antal sjukdomstillstånd som medförde liknande symptom och en förstorad prostata. Två av de vanligaste symptomen vid prostatahypertrofi, urinretention och en förstoring av körteln, förekom även vid andra sjukdomar. Till exempel kunde patienter med gonorré komma in med urinretention och förstorad prostata, men i dessa fall minskade svullnaden i prostatan vid lyckade behandlingar av de

170 Borelius 1897a, s. 236.

${ }^{171}$ Ibid, s. $236-237,252$. 
sekundära symptomen av gonorré. ${ }^{172}$ Även abscesser i prostatan kunde orsaka liknande urineringsproblem med urinretention. ${ }^{173}$

Två av de vanligaste symptomen vid prostatahypertrofi: urinretention och en förstoring av körteln, innebar inte alltid att det var en prostatahypertrofi som drabbat patienten. Diagnosen var därför något svårdefinierbar och på många sätt allt för generell. Fransmannen Mercier hade redan 1839 diskuterat problemet, samt arbetet med att utveckla instrument som skulle underlätta diagnostiseringen. Han konstaterade att urinretention var ett symptom vid flera andra tillstånd. Dessutom menade han att det lades för mycket vikt vid rektal undersökning med fingret som diagnostisk metod för prostatahypertrofi, vilket han ansåg var till föga nytta. Hur förstoringen påverkade urinröret genom krökningar och blockeringar var viktigare för diagnostiseringen än prostatans storlek, och för att undersöka detta användes katetrar som fördes upp i urinröret. ${ }^{174}$

Ibland passerade dessa katetrar obehindrat in i urinblåsan trots att patienten hade problem med urineringen. Mercier menade att det var det som hade gett upphov till teorier om att det var blåsans försvagning, och inte prostatan, som då var problemet. Ett instrument som tagits fram för att förbättra diagnostiseringsmetoden var Leroy d'Etioles kateter, sonde à inclination, som hade en kortare böj, än andra katetrar, med en böjbar led som gick att räta ut och böja igen. Den kunde böjas i en rät vinkel inne i blåsan och roteras för att läkaren skulle kunna känna om prostatan buktade in i blåsan. Mercier menade dock att även om

172 "Sjuk-Förslag från Kongl. Allm. Garnizons-Sjukhuset för året 1843 af D:r V. Lundberg. Anmärkningar för Chirurgiska Afdelningen”, Hygiea, band 6, augusti, 1844, s. 531 - 532; "Underrättelser om medicinens viktigare framsteg i utlandet. Praktiska notiser. af prof. P. E. Gellerstedt", Hygiea, band 13, januari, 1851, s. 43 - 44.

173 "Utdrag ur Embetsrapporter till K. Sundhets-kollegium. Abscessus Prostate. Rapport från Provincialläkare A. Beckman. (Gefleborgs län. Alfta distrikt.)", Hygiea, band 28, augusti, 1866, s. $321-322$.

174 Mercier 1840, s. 274. 
detta var ett bra konstruerat instrument så var det alldeles för svårt att hantera och hade för många nackdelar för att bli något som kunde användas av andra än specialister på urinvägarnas sjukdomar. ${ }^{175}$ Mercier hade istället använt en kateter med fast krökning som kunde roteras på ett liknande sätt inuti blåsan. ${ }^{176}$

Mercier påpekade att en hel del av metoderna för diagnostisering var svåra att beskriva, men lätta att lära sig när man såg någon annan göra det. ${ }^{177}$ En viktig del av kunskapsproduktionen och framförallt spridningen av kunskap var att se någon annan göra något för att sedan prova själv. Till exempel vistades den danske läkaren Axel Iversen (1844-1892)178 hos både Leopold Ritter von Dittel

175 Mercier 1840, s. 275.

176 Ibid, s. 276.

177 Ibid, s. 281.

178 Peter Axel Thorvald Iversen $(1844$ - 1892) var en dansk läkare som blev medicine doktor 1869. Han tilldelades 1872 guldmedalj för sina svar i pristävlingen om Prostatas normale Anatomi, och han var den första att införa Listers antiseptik i Danmark. År 1874 disputerade han på en avhandling med titeln Om Hypertrophia prostate. Från och med 1875 och under några år drev han en privatklinik i Köpenhamn för urinorganens sjukdomar, och det var för detta han vidareutbildade sig hos Dittel och Guyon. Under de sista åren arbetade han som kirurg vid St. Josefs hospital.

http://denstoredanske.dk/Dansk_Biografisk_Leksikon/Sundhed/L\%C3\%A6ge/Axel_Iverse n [sidan besökt 2019-09-23]. 
$(1815 \text { - 1898 })^{179}$ och Jean Casimir Félix Guyon $\left(1831\right.$ - 1920) ${ }^{180}$ och många andra kirurger reste runt till olika experter för att lära sig deras tekniker och studera de diagnostiserings- och behandlingsinstrument som de tagit fram. På detta sätt spred sig tekniker mellan länder och kontinenter. ${ }^{181}$

Utvecklingen av cystoskopet gav läkare mot slutet av 1800-talet en möjlighet att titta in i urinröret och blåsan på patienterna och se hur förstoringen påverkade urinflödet. Olika förstoringar behandlades sedan med olika ingrepp beroende på

${ }^{179}$ Leopold Ritter von Dittel (1815 - 1898) österrikisk urolog född i Tjeckien. Han tog sin medicine doktorsexamen 1840 vid universitetet i Wien. Under de kommande åren arbetade han som läkare och fortsatte att studera under flera olika läkare och kirurger. 1861 blev han utsedd till chefskirurg vid Allegemeines Krankenhaus i Wien och 1865 blev han biträdande lektor. 1864 grundade han det kirurgiska och anatomiska institutet vid Wiens universitet. Han fortsatte sedan att vara chef för detta fram till 1875 när han sa upp sig från sin akademiska position. Dittel som speciellt intresserade sig för urologi utvecklade flera innovativa kirurgiska och diagnostiska urologiska metoder. Han publicerade också ett stort antal medicinska texter under sitt liv. http://www.jewishencyclopedia.com/articles/5232-dittel-leopold-ritter-von [sidan besökt 2019-09-23].

${ }^{180}$ Jean Casimir Félix Guyon (1831-1920), var en fransk kirurg och urolog. Han studerade medicin i Paris och tog sin doktorsexamen 1858 på en avhandling om uterusmyom, som dock dateras till 1860. Guyon arbetade under åren på flera olika franska sjukhus. 1862 blev han kirurg och senare professor i kirurgisk patologi från 1877 och urogenital kirurgi från 1890 vid universitetet i Paris. 1878 blev han medlem i Académie de Médecine. Vid Hôpital Necker hade han kliniker där studenter från hela världen utbildades. 1907 grundade han tillsammans med kirurger från Europa, USA och Sydamerika Association Internationale d'Urologie. Han har fått ett antal olika tillstånd och strukturer uppkallade efter sig, även sådana som inte hade med hans specialistområde urogenitalkirurgi att göra. Han har även fått ett sjukhus i SaintDenis, Réunion, uppkallat efter sig. Han publicerade ett flertal verk bland annat Leçons cliniques sur les affections chirurgicales de la vessie et de la prostate (1888). "British Medical Journal" The British Medical Fournal, Vol. 2, Issue 3110, Aug. 7, 1920, s. 215; Nordisk Familjebok, andra upplagan, 1909 http://runeberg.org/nfbj/0395.html [sidan besökt 2019-10-05]; Jean Casimir Félix Guyon http://www.whonamedit.com/doctor.cfm/2943.html [sidan besökt 2019-10-20].

181 Schlich 2016, s. $250-254$. 
vad som ansågs vara effektivt för just den formen av förstoring, eller beroende på kirurgens personliga preferenser. Kirurger tog för operationer fram speciella instrument som de många gånger tillverkade själva, men även köpte från andra eller kopierade efter att ha besökt en kirurg som använde vissa instrument. De utvecklade olika tekniker där allt från vilken position patienten placerades i och vilka instrument som användes till valet av postoperativa behandlingar skilde sig åt. Operationstekniker kunde läras ut genom de noggranna beskrivningar som publicerades i de internationella tidskrifterna, och kirurgerna skickade instrument och andra saker som "face masks, caps, gloves, and blood-pressure measuring instruments, letters and students" till varandra. ${ }^{182}$ Behandlingen av prostatahypertrofi hade fram till början av 1890-talet byggt mycket på att kunna diagnostisera och operera med speciella instrument och på möjligheten att lära sig detta av den internationella litteraturen eller på resor.

En av de stora fördelarna med kastrering var att detta förändrades. Kastrering var inte en svår metod som behövde läras ut genom att kirurger besökte experter eller tillverkade specialinstrument. Operationen hade genomförts under årtusenden och var inte något främmande för 1890-talets kirurger som avlägsnade testiklarna på män av andra orsaker. När det gäller kastrering saknas därför nästan helt en diskussion i materialet om operationsinstrument och operationsmetod. Det behövdes inga resor och ingen behövde utveckla nya instrument för att genomföra operationen. Istället förflyttades en gammal operationsmetod till ett nytt område.

\section{Anatomin skiljs från symptomen}

I sin artikel 1897 hävdade Borelius att det inte var korrekt att använda benämningen "prostatahypertrofi" om både sjukdomen, symptomen och den

182 Peter Stanley, For Fear of Pain: British Surgery, 1790-1850, Amsterdam and New York: Editions Rodopi, 2003, s. 61 - 62; Schlich 2016, s. 249 - 251; Citat i Schlich 2017, s. 62. 
anatomiska förstoringen. Eftersom han och många andra läkare och kirurger tidigare hade kunnat konstatera att en förstorad prostata inte alltid gav upphov till en viss uppsättning symptom, eller några symptom alls, så var det felaktigt att kalla både förstoringen och symptomen för prostatahypertrofi. Borelius föredrog den uppdelning som Guyon gjort: han kallade själva sjukdomen för "prostatism”, ett kliniskt begrepp, och den patologiskt anatomiska förstoringen för "prostatahypertrofi”. Prostatism kunde alltså förekomma utan prostatahypertrofi, och vice versa. ${ }^{183}$

Om prostatism gick det enligt Borelius att läsa i "hvilken kirurgisk handbok som helst." 184 Det som intresserade honom och andra kirurger under perioden var själva hypertrofin, den patologiskt anatomiska förstoringen av prostatan: Varför uppstod förstoringen, och hur kunde man behandla den och inte bara symptomen? Här syns en förskjutning i definitionen av prostatahypertrofi eller det symptomkomplex som under lång tid kopplats antingen till prostatan eller till andra delar av det urogenitala systemet. Ett liknande exempel på en förskjuten definition är hur vaxmodeller av embryon under tidigt 1900-tal hjälpte till att konstruera graviditet som något som har med ägg, spermier och embryon att göra istället för något som en kvinna känner i sin kropp. ${ }^{185}$ På liknande sätt hjälpte prostator som plockades ut vid obduktioner, sparades som preparat och ritades av till att konstruera prostatahypertrofi som en anatomisk förändring i kroppen och inte ett symptomkomplex, något som den manliga patienten kände i sin kropp. Läkaren Edwin Hurry Fenwick beskrev hur han "specially educated my finger to detect changes in the contour of the prostate" och sedan gjorde lermodeller eller ritade bilder av dessa prostator. ${ }^{186}$

183 Borelius 1897b, s. 592.

184 Ibid.

185 Nick Hopwood, Embryos in wax. Models from the Ziegler studio, Cambridge: Whipple Museum of the History of Science, andra rättade upplagan, 2013, s. 73.

${ }^{186}$ Ingen annan läkare eller kirurg i materialet nämner dock någon form av modeller av 
Prostatans materialitet, apparater, vetenskapliga institutioner, museer och tidskrifter, i intra-aktion med läkare och kirurger, producerade en kunskap om prostatahypertrofi som både en anatomisk förändring och ett symptomkomplex. Symptomkomplexet fick namnet prostatism och kopplades isär från den anatomiska förändringen prostatahypertrofi eftersom de två enligt bland andra Borelius och Guyon inte längre ansågs ha med varandra att göra.

I och med denna uppdelning gjordes ett nytt agentiellt snitt som skilde symptom och anatomi åt. Kunskapsobjektet prostatism innefattade endast symptomen och kunskapsobjektet prostatahypertrofi endast den fysiska och strukturella förändringen av prostatan. Vid ett agentiellt snitt förloras alltid en del av intra-aktionen mellan det materiella, det semiotiska och det agentiella som utgör verkligheten. Oavsett vilka snitt som görs förloras en del av komplexiteten som i det här fallet utgörs av kroppens komplexa påverkan mellan de strukturer människor delat upp i organ, körtlar och vävnader. Många gånger var trots allt symptomen och anatomin intimt förknippade med varandra. Ofta uppvisade patienterna både en anatomisk förändring av prostatan och delar av symptomkomplexet. De fysiska förändringarna i prostatan hade ibland en direkt påverkan på symptomen och de var därför svåra att skilja från varandra. Alla läkare och kirurger gjorde inte heller samma uppdelning. Vissa föredrog att behålla den gamla nomenklaturen där prostatahypertrofi innefattade såväl symptomkomplexet som den anatomiska förändringen. ${ }^{187}$

Avgörande för kunskapsproduktionen kring förståelsen av den sjuka och friska prostatan var själva objektet, körteln i sin fysiska form. Liksom förfinade förfaranden inom kirurgin hade hjälp till att konstruera prostatan som en och inte två körtlar i början av 1800-talet hade obduktionen under 1800-talet och framförallt från 1890-talet och framåt hjälpt till att konstruera prostatahypertrofi

prostator. Fenwick 1895a, s. 529.

187 Se till exempel White 1897; Mansell Moullin 1904; Freyer 1901a. 
som en anatomisk förändring av prostatan. Denna förändring hade visat sig vara mer svårförståelig än flera läkare tidigare trott. När graden av symptom inte motsvarade graden av förstoring utövade prostatan återigen ett motstånd mot den vetenskapliga berättelse som flera läkare försökte berätta om den förstorade prostatan. Prostatans materialitet gjorde sig påmind och berättelsen om den förstorade prostatan förändrades.

Vissa läkare försökte lösa problemet genom att koppla isär symptomkomplexet och den anatomiska förstoringen, andra nöjde sig med att konstatera att symptomens grad inte hade med den anatomiska storleken att göra. När allt fler prostator plockades ut och studerades av ett flertal läkare och kirurger så att den fysiska strukturen blev synlig och kunde sättas i relation till de symptom patienten upplevt under livet förändrades berättelsen. När storleken inte längre spelade en lika stor roll riktades uppmärksamheten mot typen av förstoring. Den tredje loben, eller mellanloben, blev den struktur hos prostatan som framförallt pekades ut som orsaken till svåra symptom. Alla läkare och kirurger var dock inte överens om den tredje lobens existens.

\section{Vad ansågs orsaka prostatahypertrofi?}

De fanns flera teorier om vad som låg bakom prostatahypertrofi. "Hvad som är denna organförstorings egentliga väsende och orsak veta vi ännu icke", konstaterade den svenske läkaren Richard Warholm (1857-1942)188 under en föreläsning vid Karolinska Institutet den 6 oktober 1894. ${ }^{189}$ Tillståndets symptom

188 Axel Richard Warholm (1857 - 1942) var en svensk läkare som blev medicine doktor 1889 och arbetade under sin karriär som läkare vid Lund, Göteborg, Söderköping och Kalmar lasarett. Han var även docent i kirurgi vid Lunds universitet 1890 - 1897 och tillförordnad professor i kirurgi och obstetrik 1897 - 1898.

http://runeberg.org/spg/13/0468.html [sidan besökt 2019-10-05]. http://runeberg.org/vemardet/1933/0888.html [sidan besökt 2019-10-05]. 189 Warholm 1895, s. 403. 
och patologi beskrevs noggrant i välkända texter av August Socin, Henry Thompson, Jean Casimir Félix Guyon med flera, allt medan dess orsaker förblev okända. ${ }^{190}$ Något slutgiltigt eller enstämmigt svar skulle inte ges före min undersökningsperiods slut 1910. Men det fanns en spridd övertygelse om att prostatahypertrofi var ett sjukdomstillstånd och att det gick att avskilja från andra problem som kunde drabba prostatan. Man var också överens om att förstoringen inte orsakades av cancer, abscesser eller någon annan upptäckbar patologisk orsak som kunde tillskrivas någon annan sjukdom.

Liksom prostatan hade avgränsats från andra anatomiska strukturer hade prostatahypertrofi med ett agentiellt snitt avgränsats från andra sjukdomar och diagnoser: cancer, förstoring orsakad av gonorré, abscesser (varbölder), andra könssjukdomar och andra kända infektioner eller inflammationer. Det är dock svårare att avgöra exakt var dessa gränser drogs och om de alltid stämde. Prostatahypertrofi skapades som ett kunskapsobjekt genom uteslutning av andra möjligheter: vid avsaknad av annan känd orsak tydde urineringsproblem och en palperbart förstorad prostata på att patienten led av prostatahypertrofi. Det fanns kriterier för diagnosen prostatahypertrofi, men eftersom prostatahypertrofi både anatomiskt och symtommässigt kunde skilja sig så mycket åt från patient till patient spelade uteslutningen av andra möjliga diagnoser en roll. Trots denna osäkerhet uttalade sig läkare och kirurger under perioden många gånger säkert om att patienter led av prostatahypertrofi.

Den hypertrofierade prostatan hade inte tilldragit sig någon större uppmärksamhet förrän i slutet av 1700-talet. Symptomen hade länge varit välkända och mer eller mindre framgångsrikt behandlats men det var först vid sekelskiftet 1800 som själva förstoringen började intressera läkarna. ${ }^{191}$ Harry Shelley menar att det tidigare ointresset troligtvis berodde på att så få män under

190 Warholm 1895, s. 403.

191 Shelley 1969, s. $452-453$. 
1500- och 1600-talen uppnådde "prostataåldern", alltså 60 år och äldre. ${ }^{192}$ I slutet av 1800-talet diskuterades hur vanlig denna åkomma faktiskt var. Diverse statistiska uppgifter presenterades: cirka en tredjedel (34 procent) av alla män över 60 år hade en förstorad prostata, men endast 15-16 procent av dem hade några symptom, var tredje man över 60 år hade en förstorad prostata men endast var tionde av dem led av det, 19 procent av obducerade patienter som var 55 år eller äldre hade en förstorad prostata, 59 procent av alla män över 60 år hade en förstorad prostata. ${ }^{193}$ En slutsats är att prostatahypertrofi var vanligt bland män över 60 år men att det var ett fåtal som faktiskt led av det. ${ }^{194}$ En formulering i en bokrecension i The Lancet i slutet av november 1895 indikerar att hypertrofiering var ett så vanligt problem att det självklart upptog mycket utrymme i artiklar om prostatans sjukdomar och behandlingar: "Hypertrophy of the prostate naturally claims a large portion of the space allotted to this gland." 195 Så från att prostatan som körtel, och prostatahypertrofi som sjukdom, varit ganska okända eller ignorerade i den medicinska litteraturen under 1500-, 1600- och större delen av 1700-talet så blev prostatan under 1800-talet en känd körtel och prostatahypertrofi en sjukdom som tog stor plats i den medicinska debatten och litteraturen. ${ }^{196}$

192 Shelley 1969, s. $452-453$.

${ }^{193}$ Harrison 1888, s. 119; Reginald Harrison, "The Fibromatous Prostate", The British Medical Fournal, vol. 1, nr. 1464, jan. 19, 1889, s. 126; Maclaren 1896, s. 261; Borelius 1897a, s. 238. ${ }^{194}$ Reginald Harrison, "Clinical Remarks on Division of the Vas Deferens in Cases of Obstructive Prostatic Hypertrophy”, The Lancet, vol. 147, nr. 3782 (ursprungligen publicerad som volym 1, nr. 3782) feb. 22, 1896a, s. 473.

195 "Reviews and Notices of Books", The Lancet, vol. 146, nr. 3770 (ursprungligen publicerad som volym 2, nr. 3770) nov. 30, 1895, s. $1369-1370$.

196 Se till exempel Henry Thompsons The Diseases of the Prostate, their pathology and treatment; comprising the second edition of "The Enlarged Prostate," and a dissertation "On the healthy and morbid anatomy of the prostate gland," to which the Facksonian prize for the year 1860, was awarded by the Royal College of Surgeons of England, sjätte upplagan, London : F. E̊ A. Churchill, från 1886, Axel Iversens Hypertrophia 
Det presenterades ett antal teorier om hypertrofins orsaker, men ingen av dessa accepterades av hela den västerländska läkarkåren. Teorierna bottnade i hur man såg på prostatan som organ och fick konsekvenser för hur man resonerade om orsaken till prostatahypertrofi. Och orsaken till prostatahypertrofi fick, tillsammans med synen på vad prostatan var, konsekvenser för hur man resonerade kring kastrering och varför den skulle kunna fungera eller inte fungera som behandlingsmetod.

\section{De olika hypoteserna om prostatahypertrofins orsaker}

Det fanns framförallt två problem att förklara med prostatahypertrofi: Varför drabbades inte alla äldre män, och varför fick bara vissa av de män som hade en förstorad prostata problem? Den något äldre generationen läkare och kirurger, några av dem var fortfarande verksamma under 1890-talet, hade förklarat prostatahypertrofi som en nybildning. Borelius räknar upp Alfred Velpeau, Henry Thompson, Rudolf Virchow (1821-1902) och August Socin (1837-1899) som företrädare för denna hypotes. ${ }^{197}$ Under 1890-talet var det framförallt nyare hypoteser som diskuterades.

\section{Den franska skolan}

Förenklat kan deltagarna i debatten delas in i de som följde den så kallade Guyonska läran eller franska skolan och de som inte gjorde det. Den franske

\footnotetext{
Prostate, Kjøbenhavn Gad från 1874, Leopold von Dittels "Beiträge zur Lehre der Prostatahypertrofi”, Medizinische Jahrbücher, band 13, Wien, från 1867, August Socins arbete "Erkrankungen der Prostata", Chirurgie Band III. Erlangen 1873, Jean Casimir Félix Guyons Leçons cliniques sur les affections chirurgicales de la vessie et de la prostate, Paris : J.-B. Baillière från 1888, Chales William Mansell Moullins Enlargement of the Prostate. Its Treatment and Radical Cure från 1894 och Henri Picards Traité des Maladies de la Prostate et des vésicules séminales, Paris: G. Carré, från 1896.

197 Borelius 1897a, s. $268-269$.
} 
läkaren Joseph Casimir Félix Guyon (1831-1920) var en framstående auktoritet på området urinvägarnas sjukdomar och prostatan under senare delen av 1800talet och början av 1900-talet. ${ }^{198}$ Enligt den franska skolan berodde prostatahypertrofi på en utbredd arterioskleros, åderförkalkning, som inte bara drabbade kärlen i urinsystemets organ utan även orsakade förstoring av prostatan. En del av Guyons resonemang vilade på argumentet att arterioskleros och prostatahypertrofi drabbade patienter i samma ålder, och många av dem led samtidigt av båda åkommorna - eller enligt Guyon av en åkomma som orsakade både förkalkningen och förstoringen. ${ }^{199}$ Enligt Guyon kunde denna förkalkning även orsaka blodkongestion (blodstockning) i prostatan, vilket förklarade ytterligare några av förstoringens symptom. ${ }^{200}$ Tanken om blodkongestion skulle spela en viss roll i diskussionen om kastrering, även om de flesta kirurger utanför Frankrike under 1890-talet förkastade Guyons lära i övrigt.

Borelius ägnade en del plats i sin artikel 1897 åt att undersöka hypotesen om arterioskleros som orsak till prostatahypertrofi och konstaterade att noteringar om hjärt-kärlförändringar fanns i nästan varje obduktionsrapport han gick igenom. Han påpekade dock att det inte betydde att de kunde "sättas i något rimligt sammanhang med prostatahypertrofien”. Sådana senila förändringar var helt enkelt vanliga i den åldersgruppen. ${ }^{201}$ Guyons lära ville ge en enda förklaring till alla former av prostatahypertrofi. Med sina två satser "Alla prostator är åderförkalkade" och "Alla prostator är drabbade av blodstockning" ansåg Guyon att han förklarade alla problem med prostatism och prostatahypertrofi. ${ }^{202}$ Han hade lutat sig mycket mot Launois undersökningar för att föra fram denna idé. I

198 Borelius 1897b, s. 593; White 1893, s. 153.

199 White 1893, s. 153.

200 Borelius 1897b, s. 593.

${ }^{201}$ Borelius 1897a, s. 256.

202 "Tous les prostatiques sont athéromateux" och "Tous les prostatiques sont congestionnés", citerade i Borelius 1897b, s. 593. 
mitten av 1890-talet utförde dock den franske kirurgen Boleslas Motz (1865-1935) en undersökning av 30 hypertrofierade prostator vid Guyons klinik vars resultat snarare kullkastade Guyons lära än styrkte den. ${ }^{203}$

\section{Körtelhypotesen}

En konkurrerande hypotes om prostatahypertrofin presenterades av bland andra de två brittiska kirurgerna Joseph Griffiths och Charles Mansell Moullin (18511940). ${ }^{204}$ Hypotesen gick ut på att förstoringen var en körteltillväxt som berodde på tillväxten av rörformiga adenom, godartade tumörer. Liksom anhängarna av den franska skolan hade Grifftihs och Mansell Moullin noterat att det i många fall kunde observeras en bindvävstillväxt i den förstorade prostatan. De bedömde dock att den var sekundär till tumörtillväxten och inte hade något att göra med arterioskleros. ${ }^{205}$ Detta resonemang skulle bli viktigt för Fredrik Ramms och William Whites resonemang om likheterna mellan uterusmyom och prostatahypertrofi. 206

I en artikel 1892, året innan kastrering föreslogs som behandlingsmetod, argumenterade Mansell Moullin för körtelhypotesen. Han hade de främsta auktoriteterna på området mot sig: Reginald Harrison hävdade förutom sin "muskelteori" att urinretention ofta föregick en egentlig förstoring av prostatan;

203 Borelius 1897b, s. 593.

${ }^{204}$ Charles William Mansell Moullin $(1851$ - 1940) var en engelsk kirurg som utbildade sig i Oxford och tog sin medicine doktorsexamen där 1879. Han flyttade sedan till London och efter ett antal tjänster blev han färdigutbildad kirurg 1890. Under sitt verksamma liv undervisade Mansell Moullin mycket i bland annat anatomi, komparativ anatomi, fysiologi och kirurgi. Han hade flera intresseområden varav urogenital kirurgi var ett. Efter en föreläsning om operativa behandlingar för prostatahypertrofi han höll 1892 publicerades en bok baserad på denna som trycktes i fyra upplagor. O’Connor 1991, s. 273.

205 Mansell Moullin 1892a, s. 1230 - 1231; Mansell Moullin 1896a, s.115. 206 White 1893, s. 153. 
Thompson hävdade att han inte kunnat finna en enda patient som fått tillbaka hela sin blåsfunktion efter ett ingrepp på prostatan, vilket i förlängningen betydde att det inte var prostatan som var det egentliga problemet vid retention och urineringsbesvär; och Guyon hävdade att hypertrofin och de besvär som den gav berodde på att hela urineringsapparaten angripits av arterioskleros.

Mansell Moullin hävdade däremot att det var förstoringen av prostatan som var den direkta orsaken till besvären. Förändringar i blodkärl eller blåsan kunde bidra till besvären, men prostatahypertrofi var en helt lokal sjukdom och de komplikationer som följde var en effekt av den blockering som förstoringen orsakade. Tog man bort det som hindrade urinens flöde kunde man förebygga utvecklingen av komplikationer såsom förslappningar av blåsmuskulaturen. ${ }^{207}$

\section{Muskelteorin}

Reginald Harrisons teori om varför prostatan förstorades byggde på hans teori att prostatan var en muskel. Han menade att prostatan kunde förstoras till följd av överanvändning precis som andra muskler. Prostatans tillväxt hos äldre män såg han som en kompensatorisk effekt, att musklerna i den förstorades för att kunna hålla upp urinblåsan och sluta tätt när urinblåsans egna muskler blivit förslappade, något som i de flesta fall inte var att betrakta som patologiskt eller skadligt. De flesta hade enligt Harrison snarare nytta av sin förstorade prostata. Hos vissa personer gick dock denna kompensatoriska effekt till överdrift, och det var då det uppstod problem. ${ }^{208}$

207 C. W. Mansell Moullin, "Lectures on the Operative Treatment of Enlargement of the Prostate", The Lancet, vol. 139, nr. 3588, june 4, 1892, s. 1229. 208 Reginald Harrison, "Lettsomian Lectures on some points in the surgery of the urinary organs", The British Medical Fournal, vol. 1, nr. 1412, jan. 21, 1888, s. 119; Reginald Harrison, "The Fibromatous Prostate", The British Medical fournal, vol.1, nr. 1464, jan 19, 1889, s. 126; Reginald Harrison, "Observations on the Pathology of Enlarged or Hypertrophied Prostate", The British Medical fournal, vol. 2, nr. 1826, dec. 28, 1895, s. 1606. 
Vidare menade Harrison att själva förstoringen berodde på att urineringsfunktionen hos barn låg bortom vilja och kontroll och förmågan att hålla sig var något som män lärde sig med åren. Att hålla sig för länge fick negativa konsekvenser: prostatamuskeln klarade denna påfrestning i unga år men det ledde till en förstorad muskel när man blev äldre: "If a man goes on using his bladder as he would a water-bottle, from adolescence to old age, he must not be surprised if Nature prevents it breaking down entirely by the process I have described." menade Harrison. ${ }^{209}$

\section{Andra spekulationer kring orsakerna}

Förutom dessa tre mer utarbetade teorier om orsakerna bakom prostatahypertrofi fanns det andra spekulationer. Harrison menade att man kunde dra på sig sjukdomen om man hade blivit blöt och kall eller suttit på ett blött och kallt underlag, eftersom det enligt Harrison orsakade en svullnad i prostatan som följdes av retention. Vissa läkare menade att överdriven konsumtion av alkohol eller sexuell excess kunde orsaka prostatahypertrofi, men både White och Harrison menade att det inte fanns tillräckligt med bevis för att så skulle vara fallet. ${ }^{210}$ I det material jag undersökt är spekulationer kring hur sexuell aktivitet kunde påverka prostatan i förhållande till prostatahypertrofi få. Det är förvånande mot bakgrund av tidigare studier av perioden, som till stor del framhåller läkarkollektivet och samhällets fixering vid manlig sexualitet och vad ett omoraliskt sexuellt beteende kunde leda till. ${ }^{211}$ Varje gång sexuellt beteende nämns i materialet som en möjlig orsak bakom prostatahypertrofi avfärdas det

\footnotetext{
${ }^{209}$ Harrison 1888, s 120.

${ }^{210}$ Harrison 1889, s. 126; White 1895d, s. 2.

211 Se till exempel Larsson 2002; Ekenstam 1993; McLaren 2007; Darby 2005a; Darby 2005b; Bayuk Rosenman 2003; Stephens 2008.; Verhoeven 2015.
} 
snabbt med argumentet att det inte fanns något som understödde att så skulle vara fallet. ${ }^{212}$

Enligt Borelius fanns det de som velat hävda en koppling mellan ett stillasittande yrke och prostatahypertrofi. Denna tanke hängde samman med tanken om att blodkongestion till bäckenorganen var en orsak till förstoring, alltså den franska skolan. Men vid en genomgång av obduktionsprotokollen från Uppsala kunde Borelius inte hitta något samband mellan yrke och prostatahypertrofi. ${ }^{213}$

Det vaskulära systemet, som stod i centrum för den franska skolan i och med hypotesen att hypertrofin orsakas av arterioskleros, återkom i den tyske kirurgen Willy Meyers (1858-1932) hypotes. ${ }^{214}$ Meyer menade att prostataförstoring berodde på hyperemi, en ökad blodmängd, i prostatan. Beviset för detta såg han i att ligering, att knyta av blodkärlen till prostatan, men även kastrering var effektiva behandlingsmetoder. Enligt Meyer fungerade ligering för att den ströp blodtillförseln och kastrering för att den kapade den påverkan testiklarna hade på prostatan genom nerverna som orsakade förstoringen. Om testiklarna avlägsnades försvann hyperemin och prostatan krympte..$^{215}$

\footnotetext{
212 Harrison 1889, s. 126; White 1895d, s. 2.

${ }^{213}$ Borelius 1897a, s. $254-255$

214 Willy Meyer (1858 - 1932) föddes och utbildade sig i Tyskland. Han tog sin medicine doktorsexamen 1880 men emigrerade 1884 till New York. Där etablerade han sig som kirurg och 1886 blev han utsedd till professor i klinisk kirurgi, en av många positioner han skulle inneha under sitt liv. Han introducerade många europeiska uppfinningar och tekniker i USA såsom cystoskopet, manlig kateterisering av urinledarna och Bottinis operation för prostatahypertrofi. Han hade under sitt verksamma liv flera specialistområden bland annat kateterisering och prostatektomi, men även bröstcancer. Franz Torek, "Willy Meyer, MD., 1858 - 1931", Annals of Surgery, vol. 97, nr. 1, jan, 1933, s. $156-158$.
}

215 Meyer 1894, s. $50-51$. 
Även Mansell Moullin menade att testiklarna på något sätt skulle kunna ligga bakom prostatahypertrofi. ${ }^{216}$ Borelius fann hypotesen intressant och menade att möjligheten att förändringar i testiklarna kunde vara orsaken motiverade fortsatta försök med kastrering som behandlingsmetod, men han påpekade att detta ännu bara var teoretiska spekulationer. ${ }^{217}$ I sin artikel 1897 nämnde Borelius ytterligare en hypotes som 1896 hade publicerats i den tyska tidskriften Centralblatt für Chirurgie: att prostatahypertrofi var "resultatet af en kronisk inflammatorisk process". 218

De olika former av förstoringar av prostatan som Borelius kunnat observera under sina egna undersökningar av museipreparat och obduktionsprotokoll fick honom att misstänka att det fanns "flera väsentligen olikartade former af prostataförstoring". ${ }^{219}$ Hur kunde man annars förklara att det fanns förstorade prostator med nybildade muskelceller, andra med en ökning av körtelceller och körtlar och ytterligare andra med tydliga sklerotiska förändringar?220 Det tycktes ge visst stöd för alla de mer inflytelserika berättelserna om den hypertrofierade prostatans orsak: att prostatan var en muskel och förstorades för att muskler som överanvänds kan förstoras, att prostatan var en körtel och att prostatahypertrofi berodde på en ökad mängd körtelvävnad och att prostatahypertrofi orsakades av en utbredd åderförkalkning.

Oavsett vad som orsakade prostatahypertrofi ledde Borelius genomgång av obduktionsprotokoll till en annan viktig slutsats: en stor del av personerna med prostatahypertrofi hade även lidit av hjärt-kärlproblem och problem med njurarna. Det innebar enligt Borelius att operativa behandlingar av denna patientgrupp kunde vålla komplikationer, och det var viktigt att vid valet av

\footnotetext{
216 Mansell Moullin 1894b, s. 908.

${ }^{217}$ Borelius 1897b, s. 593.

218 Borelius 1897a, s. 269.

219 Ibid.

${ }^{220}$ Ibid.
} 
behandling väga in patientens allmäntillstånd. ${ }^{221}$ Problemen med patienternas dåliga allmäntillstånd var en av de mest drivande faktorerna bakom att kastrering föreslogs och att den fick ett snabbt genomslag bland vissa kirurger.

\section{Kunskapsläget under 1890-talet}

Det rådde stor oenighet om prostatahypertrofins orsaker. "Ingen af dessa åsigter, ej heller någon annan bland de många som framställts, synes mig kunna tillerkännas allmängiltighet”, skrev Borelius 1897. ${ }^{222}$ Han bedömde dock att den franska skolan hade haft flest "eftersägare" under det senaste decenniet.223 Vid flera tillfällen efterlystes ytterligare studier och att fler läkare skulle rapportera om sina fall och fynd. Exempelvis efterfrågade en läkare är 1893 studier om körtelns anatomi och patologi hos olika människoraser och hos lägre djur samt studier om prostatahypertrofins orsaker. $^{224}$ Borelius sammanfattade kunskapen om prostatismen, alltså själva symptomkomplexet, på följande sätt: "Prostatismen synes mig kunna fattas såsom en från början funktionell rubbning, hvars verkliga orsak man icke känner, men för hvilkens uppkomst följande moment predisponerar: högre ålder (55-70), prostatahypertrofi, allmän arterioskleros, samt till sist, och fullkomligt hypotetiskt, vissa från testiklarne utgående impulser." 225

Olika läkares och kirurgers syn på prostatahypertrofi skapade olika teorier som innefattade olika anatomiska förändringar och olika tolkningar av symptom. Intra-aktionen mellan läkare, teorier, apparater, och prostatan såg olika ut och producerade olika kunskap om prostatahypertrofi. Den franska skolan lade ingen

\footnotetext{
${ }^{221}$ Borelius 1897a, s. 257.

222 Ibid, s. 269.

223 Ibid.

${ }^{224}$ MacMunn 1893, s. 709.

225 Borelius 1897b, s. 594.
} 
vikt vid förändringar i körtelvävnaden i prostatan utan fokuserade på de strukturella förändringar som kunde kopplas till arterioskleros. Det påverkade hur symptomen förklarades och vilka behandlingar som föreslogs. Den enda behandling som egentligen rekommenderades var kateterisering, eftersom andra behandlingar inte löste grundproblemet, arteriosklerosen. Intra-aktionen producerade en kunskap där prostatahypertrofi kopplades till en annan sjukdom, som drabbade en större del av kroppen än bara prostatan. Den vetenskapliga berättelsen om prostatahypertrofi blev i denna teori en utveckling av den mer allmänna berättelsen om arterioskleros och dess följder, och identifierade den som en senil sjukdom.

De som anslöt sig till körtelhypotesen menade att godartade tumörer låg bakom prostataförstoring. Teorin innefattade alla de strukturella förändringar av prostatans anatomi som visade på förändringar i körtelvävnaden och tillväxt av adenom. Tecken som skulle kunnat tyda på arterioskleros ignorerades. Prostatan betraktades som en körtel, dessutom en körtel som tillhörde det sexuella systemet. Det gjorde kastrering till en möjlig behandlingsmetod eftersom en påverkan mellan testiklarna och prostatan sågs som trolig, men även dessa läkare rekommenderade först och främst kateterisering. Intra-aktionen kom här att resultera i en annan kunskap om prostatahypertrofi. Kateterisering användes i stor utsträckning men även andra behandlingar föreslogs och användes. Den vetenskapliga berättelse som berättades av dessa läkare och kirurger utgick från en teori där prostatan var en körtel och en teori där prostatahypertrofi var en tillväxt av godartade tumörer i prostatan.

Den sista av de mer utarbetade hypoteserna om prostatahypertrofins orsaker var muskelteorin, och den innebar en helt annan tolkning och förståelse av prostatans själva anatomi. Teorins främste förespråkare var Harrison, och hans intra-aktion med prostatan skapade en annorlunda kunskap om körtelns anatomiska funktion och om prostatahypertrofi som sjukdom. Teorin var inriktad på att prostatan var en muskel och att prostatahypertrofi var en förstoring av 
denna muskel, och alla körtelfunktioner sågs som sekundära och underordnade den muskulära funktionen. Harrison skilde sig inte speciellt mycket från de läkare som såg prostatan som en körtel när det gällde behandlingar. Intra-aktionen mellan Harrison och prostatan resulterade inte i andra behandlingsmetoder även om prostatan och prostatahypertrofi förklarades annorlunda. Den stora skillnaden var att han inte ansåg att kastrering skulle vara en gångbar metod.

Alla dessa teorier utgick först och främst från vad läkare och kirurger menade att de kunde se i den döda kroppen vid post mortemundersökningar och i mikroskopet när prostatan plockats ut. Vilka strukturer som gavs vikt och betydelse var avhängigt av teorin, vilken skapades i intra-aktionen mellan läkarens övertygelse om prostatans funktion, utseende och placering i kroppen och prostatans materialitet; de apparater som tekniska verktyg, katetrar, sonder, cystoskop, mikroskop, fingrar och ögon som användes; men även praktiker som operationer, rektala undersökningar och post mortemundersökningar. Till detta kom läkarens tidigare kunskaper och erfarenheter - och hans ålder, eftersom medicinutbildningen förändrades mycket i slutet av 1800-talet vilket påverkade läkarnas förkunskaper och vilka tekniker de använde för att lösa problem. I intraaktionen ingick dessutom andra läkare och de nätverk de hade tillgång till för att utbyta information, tekniska verktyg och prostatapreparat genom att besöka kollegor, medverka vid konferenser och möten, läsa tidskrifter och be kollegor att skicka preparat.

Den stora sammanflätningen av faktorer som i intra-aktion påverkade hur läkare och kirurger skapade sina teorier om prostatan och prostatahypertrofi gav en stor frihet att tolka och framhålla vissa perspektiv, anatomiska delar och funktioner på bekostnad av andra, men det fanns begränsningar. Det gick till slut inte längre att hävda att prostatan var en muskel eftersom dess materialitet motsatte sig denna tolkning. Ingenting i prostatans anatomi, funktion eller struktur gick att tolka som att prostatan var en muskel när den väl undersökts allt mer noggrant och observerats både makroskopiskt och mikroskopiskt hos både levande 
och döda patienter. Detta tyder på det materiellas vikt för en teoris hållbarhet och överlevnad. När något fysiskt som en prostata är inblandat kommer denna materialitet innebära både möjligheter och begränsningar för de tolkningar och den kunskap som kan produceras om denna, om det sammanhang detta sker i är styrt av vissa regler för hur kunskap kan produceras.

Inom medicinen runt sekelskiftet hade den moderna vetenskapliga metoden med sina krav på stöd genom observation, experiment och så vidare slagit igenom tillräckligt mycket för att vetenskapssamhället skulle ställa krav på de teorier och kunskapsobjekt som skapades. För att prostatan skulle kunna ses som en muskel eller körtel krävdes det bevisning, liksom för att man skulle kunna hävda att en behandlingsmetod fungerade. Detta krav var dock på intet sätt absolut. Synen på organs och körtlars funktion och sjukdomar var, och har fortsatt att vara, öppen för tolkningar och behandlingar utan empiriska belägg eller bevis för effektivitet tonsillektomierna var ett utslag av detta. En förklaring kan vara den vikt som inom medicinen läggs vid klinisk erfarenhet. När en sjukdom eller behandling upplevs fungera på ett visst sätt eller hjälpa har läkarvetenskapen många gånger valt att rätta sig efter det, trots svagt eller obefintligt vetenskapligt underlag.

Jag kommer att återkomma till, och diskutera närmare, hur detta påverkade synen på prostatahypertrofi kring sekelskiftet 1900 i nästa empiriska kapitel. I detta kapitel har jag nämnt Velpeaus analogi med uterus, och de så kallade lobuli som observerats i prostatan. Det var denna hypotes som framförallt vidareutvecklades av Ramm och White och gjorde kastrering till en möjlig behandlingsmetod. Nästa empiriska kapitel kommer att djupdyka i denna hypotes: dess historia, argumenten för och emot och dess mycket intressanta roll i historien om kastrering som behandlingsmetod för prostatahypertrofi. Innan detta kommer jag dock ge en översikt över de befintliga behandlingsmetoder som fanns att tillgå för prostatahypertrofi och en kort sammanfattning av kastrering som behandlingsmetod för prostatahypertrofi. 


\section{Behandlingsmetoder för prostatahypertrofi i slutet av 1800-talet}

För att kunna förstå varför kastrering övervägdes som behandlingsmetod vid prostatahypertrofi och praktiserades av flera läkare behöver vi förstå vilka behandlingsalternativ som fanns. I detta kapitel går jag översiktligt igenom de traditionella och även nyare metoder som fanns att tillgå för 1890-talets läkare och kirurger samt presenterar kortfattat kastrering som behandlingsmetod, hur den lanserades och togs emot och hur den sedermera upphörde.

\section{Kirurgi och lindrande vård}

Vid 1890-talets början fanns det ett antal palliativa (lindrande) och operativa behandlingar, eller så kallade radikalbehandlingar, som kunde användas vid prostatahypertrofi. De skilda hypoteserna om prostatan och orsakerna bakom prostatahypertrofi hade gett upphov till skilda behandlingsmetoder. Dessa hade till viss del formats av beprövade metoder som använts under lång tid och av mer eller mindre kvalificerade gissningar. Tiden innan 1800-talet hade präglats av försök att lindra symptomen som förstoringen gav, alltså urineringsproblem, smärta och de infektioner som följde på kateterbehandlingen. Det var först efter den utveckling som skedde inom kirurgin under första halvan av 1800-talet som man från ungefär mitten av 1800-talet hade ett visst hopp om att en dag kunna åtgärda förstoringen.

Vid 1890-talets början hade en hel del stora förändringar skett inom medicinen. Humoralpatologin, som dominerat sedan antiken, hade fått ge vika 
för nya perspektiv på sjukdom och kroppen. Fokus hade flyttats från föreställningen om en balans mellan kroppens fyra vätskor till nerverna. Teorier om hur nervsystemet kunde påverka kroppen gjorde att nu ansågs nerver och fibrer kunna spännas och retas på olika sätt. ${ }^{226} \mathrm{En}$ av dessa teorier var reflexteorin, som sade att ett organ som blivit irriterat kunde påverka vilket annat organ i kroppen som helst, utan påverkan från hjärnan. ${ }^{227}$ En annan förklaringsmodell som blev populär under 1800-talet var att nervsystemet förmedlade signaler inte bara mellan kroppens organ utan även mellan körtlar och resten av kroppen. Det var dock ett antagande snarare än något man kunde visa. ${ }^{228} \mathrm{I}$ en tid innan hormoner börjat fungera som en förklaringsmodell för hur exempelvis testiklarna påverkade kroppen var det flera läkare och kirurger som spekulerade om ett nervförhållande mellan testiklarna och till exempel prostatan. Vissa funderade på om nerverna kunde påverka andra delar av kroppen, till exempel genom något ämne som utsöndrades av testiklarna. En läkare avfärdade rakt av att ett sådant ämne skulle kunna transporteras med blodet, eftersom bara vissa delar av kroppen verkade påverkas av vad det nu var som testiklar och ovarier producerade. Men

226 Shorter 1992, s. 14 - 15; Karin Johannisson, Medicinens öga: [sjukdom, medicin och samhälle historiska erfarenheter], [Ny utg.], Norstedt, Stockholm, 2013, s. 30.

${ }^{227}$ Johannisson 1995, s. 31.

228 Sengoopta 2006, s. 11 - 12; För diskussioner kring testiklarnas påverkan på kroppen och prostatan genom nerverna i materialet se till exempel: "Nordiska kirurgiska föreningens tredje möte i Helsingfors den 12-14 augusti 1897.” Refererat av Anders Hansson i Hygiea, band 59, oktober, 1897, s. 391 - 392; Joseph Griffiths, "The Condition of the Testes and Prostate Gland in Eunuchoid Persons", fournal of Anatomy and Physiology, vol. 28 (Pt2), jan. 1894, s. $224-$ 225; Mansell Moullin 1894b, s. 909; Charles William Mansell Moullin, "On the Treatment of Enlargement of the Prostate by Removal of the Testes", The British Medical fournal, vol. 2, nr. 1766, nov. 3, 1894c, s. 976; A. G. Faulds, "Castration for Enlarged Prostate", The British Medical fournal, vol. 1, nr. 1792, maj 4, 1895, s. 975. 
synen på sjukdom påverkades också av den utveckling som följde med antiseptiken, aseptiken, anestesin och bakteriologin. ${ }^{229}$

Även tekniska förändringar påverkade synen på kroppen. Mikroskopet var ett av de viktiga instrument som skulle möjliggöra en ny förståelse för kroppen och sjukdom. Redan i början av 1800-talet hade de nya akromatiska mikroskopen inneburit att kroppens mindre beståndsdelar blev synliga. Några av de tidigaste mikroskopen konstruerades av Antonie van Leeuwenhoek (1632-1723), men de hade bara en lins och uppförstoringsförmågan var dålig. Senare konstruerades mikroskop med två likadana linser, men de hade fortfarande en begränsad uppförstoringsförmåga. Runt 1758 upptäckte den brittiske optikern John Dollond (1706-1761) att en konstruktion med två olika linser, istället för två likadana, kunde lösa dessa problem. 1827 publicerades för första gången en undersökning med tillhörande mikroskopiska bilder av blodceller. ${ }^{230}$

Denna upptäckt av celler gjorde att cellteorin växte fram under 1840-talet, vilket gav nya möjligheter att förklara sjukdomar och medförde att nya behandlingar föreslogs. ${ }^{231}$ Prostatavävnaden hamnade nu under mikroskopet och det blev möjligt att se strukturer och förändringar som tidigare varit osynliga.

${ }^{229}$ Antiseptik innebar att bakterier under eller efter exempelvis en operation dödades med bakteriedödande medel. Dess främste förespråkare, och den som anses ha kommit på idén under 1800-talet, var Joseph Lister (1827 - 1912). Allan Chapman Physicians, Plagues and Progress. The History of Western Medicine from Antiquity to Antibiotics, Lion, Oxford, 2016, s. 416 418. Aseptik innebar att kirurger och läkare tillämpade allmän renlighet. De tvättade händerna, bar rena kläder, tvättade alla instrument och operationsrummet noga och så vidare. Den främste förespråkaren för detta var under 1800-talet Robert Lawson Tait (1845 1899). Chapman 2016, s. 398 - 399, 402 - 405. Anestesi innebar nedsövning eller bedövning av patienter, ofta med kloroform eller morfin. Bakteriologin innebar att under 1870-talet började bakterier att identifieras och att ses som orsaken till vissa sjukdomar. Det gav en ny förklaring till att människor blev sjuka. Chapman 2016, s. 382 - 383, 388 - 393.

${ }^{230}$ Chapman 2016, s. 373 - 375, 377.

231 Ibid, s. 379, 382. 
Prostatan genomgick därför som kunskapsobjekt en omvandling. Åsikten att prostatan var en körtel hade funnits innan, men dess funktion och uppbyggnad var fortfarande något av ett mysterium. Mikroskopet kunde visa körtlar och körtelgångar, muskelvävnad, de strukturer som kallades lobuli och de strukturella förändringar som skedde på grund av ålder och hypertrofiering av prostatan.

Vad fanns det för behandlingar mot prostatahypertrofi innan kastrering föreslogs och testades? Ett av de första och absolut vanligaste symptomen på att något inte var som det skulle med prostatan var urineringsproblem - ofta retention, ett tillstånd som kunde bli akut och livshotande - och i andra fall behov att urinera väldigt ofta, urinläckage eller så svag stråle att urinen endast droppade ut. Urineringsproblem var inget nytt område inom medicinen utan hade diskuterats redan i papyrusrullar på 1400-talet f.Kr. Under antiken ansåg Hippokrates (ca 460 f.Kr. -370 f.Kr.) att akut urinretention borde behandlas med laxering. ${ }^{232}$

Det vanligaste instrumentet för behandling av urineringsproblem var katetern, och det hade den varit i närmare 2000 år. ${ }^{233} \mathrm{Om}$ antingen urinröret av någon anledning trycktes ihop eller en utväxt blockerade det så kunde en kateter föras upp för att öppna upp urinröret så att urinen kunde rinna ut. Den första kända metallkatetern konstruerades under det första århundradet e.Kr. År 1036 utvecklade den persiske läkaren Avicenna en mer flexibel kateter. ${ }^{234}$ Ambroise Paré (ca 1510-1590) en fransk kirurg, var den förste som använde en kateter konstruerad så att den kunde skära bort delar av prostatan för att avlägsna blåshalshinder, de hinder i urinblåsans hals som kunde försvåra urintömningen. Denna teknik vann dock inte popularitet förrän under 1800-talet, då flera franska

232 Shackley 1999, s. 776.

233 Ibid.

234 Ibid. 
kirurger, som Leroy d'Etoilles (1798 - 1860), Jean Civiale (1792 - 1867) och Louis Auguste Mercier (1811 - 1882) började använda tekniker (kallade prostatomia och

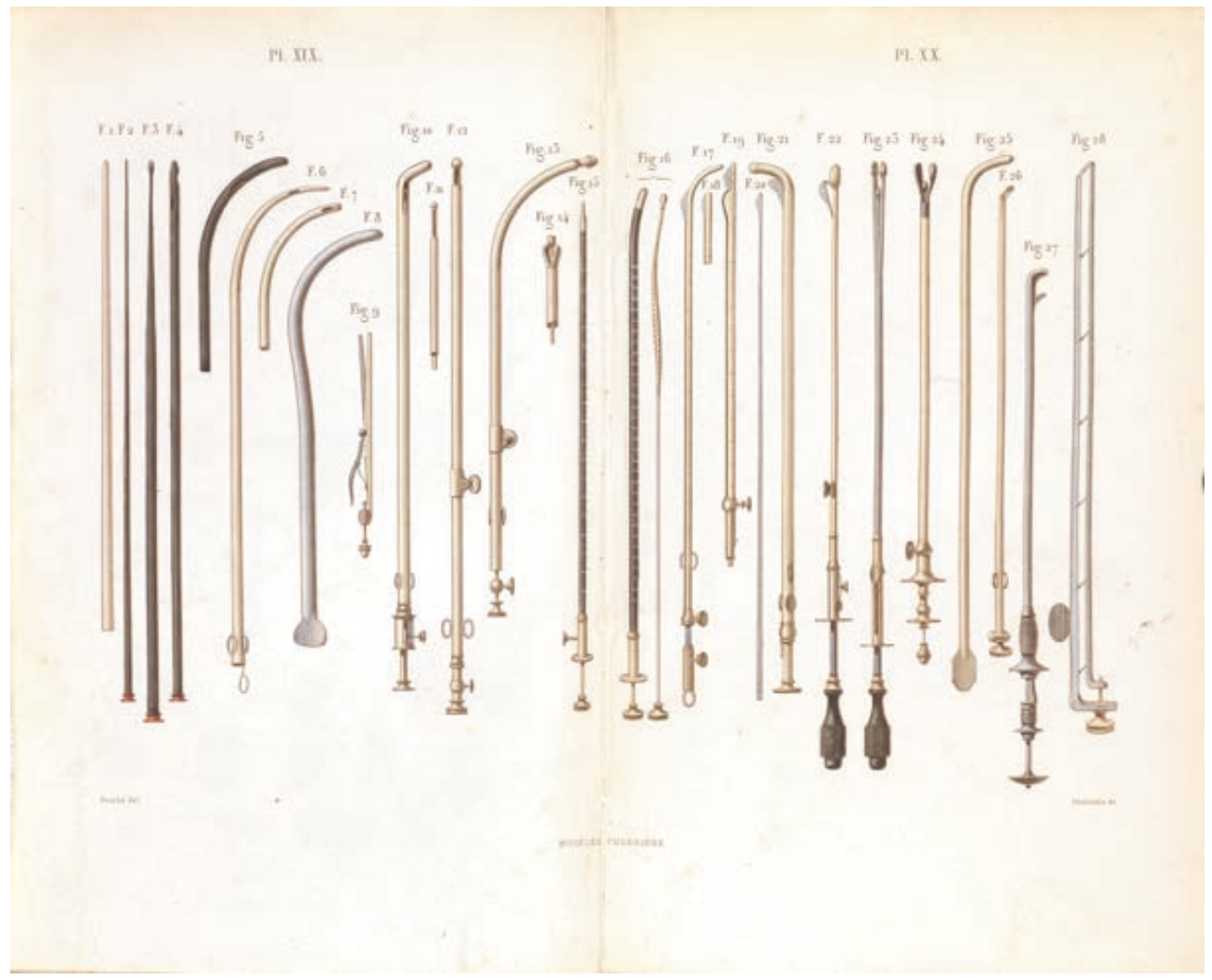

Plansch XIX-XX, kirurgiska instrument för behandling av sjukdomar i urinröret och prostatan. Källa: Wellcome Collection. CG BY.

prostatectomia urethralis) för att via urinröret avlägsna delar av prostatan eller de utväxter som förhindrade urinens flöde. Oftast gick det till så att en kateter med en dold klinga eller sekatör fördes in i urinröret och sedan fälldes ut varpå man skar bort eller stansade ut delar av prostatan som kunde föras ut genom urinröret. ${ }^{235}$ Ingreppet orsakade ofta en kraftig blödning. Patienten fick ligga med

235 Shackley 1999, s. 777; Warholm 1895, s. 406 - 407; Ramm 1896, s. 3; Charles William Mansell Moullin, "Lectures on the Operative Treatment of Enlargement of the Prostate", The 
bäckenet upphöjt, absolut still, med en kateter på plats för att hålla den del av urinröret som gick genom prostatan utvidgad. Även kalla insprutningar och insprutning av sammandragande medel i urinblåsan användes för att begränsa blödningarna. Enligt den svenske kirurgen Richard Warholm var det främst franska kirurger som använde dessa behandlingsmetoder, och de togs ur bruk nästan helt efter Merciers död. ${ }^{236}$

Den italienske läkaren Enrico Bottini (1835-1903) lyckades 1876 förbättra tekniken något med sin elektro-galvaniska metod, som innebar att delar av prostatan brändes bort med elektrisk ström genom en metalltråd i änden av katetern. Blödningen minskade då tack vare att såret kauteriserades. ${ }^{237}$ Denna metod fick dock inget större genomslag och det rapporterades om att resultatet ur funktionellt hänseende inte varit tillfredsställande; förstoringen visade sig kunna fortsätta växa ostört. ${ }^{238}$

En annan teknik som användes men inte bedömdes vara effektiv var att föra in tjocka katetrar i urinröret för att försöka komprimera prostatan. ${ }^{239}$ Kateter användes även för vissa "radikalbehandlingar". En sådan var forcerad kateterisering: man förde in en kateter tills det tog stopp, pressade sedan igenom den med våld och skapade på så sätt en ny väg genom prostatan för att kunna tömma urinblåsan. ${ }^{240}$ Forcerad kateterisering har beskrivits redan i forntida Egypten och tidiga hinduiska skrifter. Tillsammans med stenutskärning (litotomi, att avlägsna stenar ur urinblåsan, ofta genom ett snitt i mellangården), är det två

\footnotetext{
Lancet. vol. 139, nr. 3589 (ursprungligen publicerad som volym 1, nr. 3589) juni 11, 1892b, s. 1288.

236 Warholm 1895, s. $406-407$.

237 Shackley 1999, s. 777; Warholm 1895, s. 406 - 407; Ramm 1896, s. 3; Mansell Moullin 1892b, s. 1288.

238 Ramm 1896, s. 4.

239 Warholm 1895 s. 405 - 406; Ramm 1896, s. 3.

240 Warholm 1895 s. 405 - 406; Ramm 1896, s. 3.
} 
av de äldsta beskrivna operationerna i världen. ${ }^{241}$ Att gå in med kateter eller andra instrument via urinröret hade flera nackdelar. Det var dels, som den svenske läkaren Richard Warholm beskrev det, "som att famla i mörker". ${ }^{242}$ Och dels var problemet bakterier, jag kommer att återkomma till detta.

Mot slutet av 1800-talet blev kirurger mer ambitiösa när det gällde invasiva operationstekniker. I och med antiseptiken, aseptiken och anestesins utveckling minskade dödligheten. ${ }^{243}$ Utvecklandet av det första belysta cystoskopet 1878 av den tyske urologen Maximillian Nitze (1848-1906) i Berlin gjorde det möjligt för kirurgerna att för första gången visuellt kunna utvärdera urinrörsförträngningar i prostatan. ${ }^{244}$ Senare skulle Nitze även konstruera ett mer avancerat cystoskop med fler funktioner, och med det tog han det första endoskopiska fotografiet. Dessutom publicerade han den första läroboken i urologi. ${ }^{245}$

Till skillnad från de franska kirurgerna föredrog de brittiska kirurgerna i mitten av 1890-talet prostatectomia suprapubica, som innebar att kirurgen, efter att ha satt en kateter in genom buken in i urinblåsan, gjorde ett snitt ovanför blygdbenet

241 Valier 2016, s. 47.

242 Warholm 1895, s. $406-407$

${ }^{243}$ Johannisson 1995, s. 24; Schlich 2017, s. 53.

${ }^{244}$ Shackley 1999, s. 777. Joshua S. Engelsgjerd \& Christopher M. Deibert, Cystoscopy.

[Updated 2019 Jul 16]. In: StatPearls [Internet]. Treasure Island (FL): StatPearls Publishing; 2019 Jan-. Available from: https://www.ncbi.nlm.nih.gov/books/NBK493180/ [sidan besökt 2019-10-17], "Introduction".

${ }^{245}$ HW Herr, "Max Nitze, the cystoscope and urology", fournal of Urology, vol. 176, nr. 4, okt., 2006, s. $1313-1316$. 


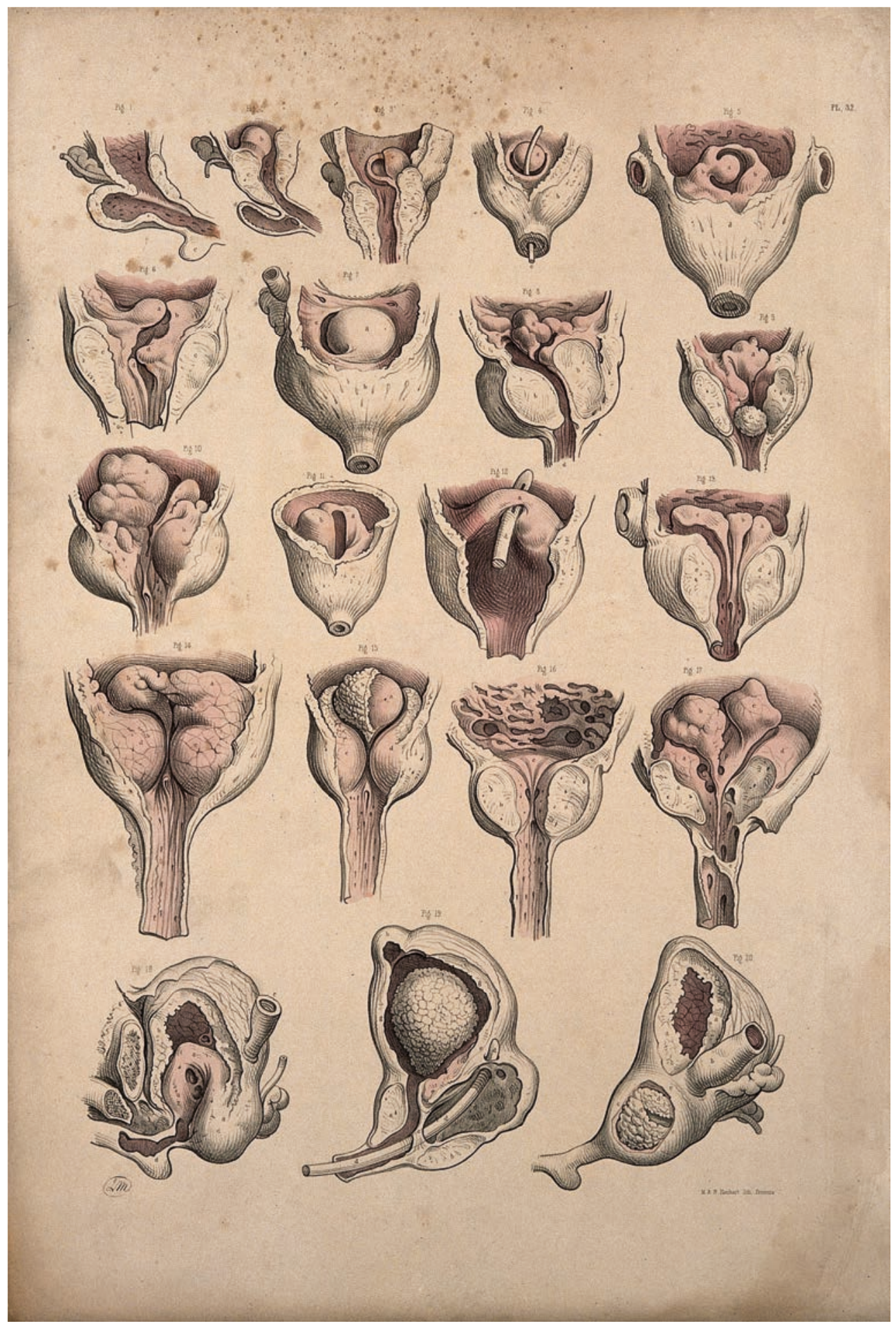

Prostatakirurgi. Färgad litografi av J. Maclise, 1851. Credit: Wellcome Collection. CG BY. 
och genom snittet skar bort de delar som hindrade urinflödet. Sedan lämnades en tjock kateter i urinröret under läkningen. ${ }^{246}$ Detta var den enda metod där kirurgen något så när kunde se vad han gjorde och fick en möjlighet att undersöka urinröret och urinblåsan. ${ }^{247}$ Den första dokumenteringen av en genomförd suprapubisk prostatektomi är från 1827. Olika tekniker för detta ingrepp beskrevs vid flera tillfällen under 1800 -talet. ${ }^{248}$

Operationen kunde även genomföras genom rektum, en metod som introducerats av Reginald Harrison. ${ }^{249}$ Det var dock först kring sekelskiftet 1900 som prostatektomi började användas mer frekvent. Arthur Ferguson McGill $(1846-1890)^{250}$ presenterade vid Clinical Society 1888 ett antal fall av prostatahypertrofi då han framgångsrikt använt sig av suprapubisk prostatektomi, och det var det första egentliga framsteget med operationer för allvarligare former av prostatahypertrofi. Ingreppet kom att kallas McGills operation. Fram till dess hade ingen övervägt operationer som faktiskt kunde bota patienterna. Men det var ändå bara de allvarligaste fallen som kom i fråga för operation, vilket betydde att patienten ofta var mycket sjuk vid operationstillfället. ${ }^{251}$ Det är viktigt att komma ihåg inför diskussionen om kastrering.

Perineal prostatektomi, att gå in genom ett snitt i mellangården, var en metod som utvecklats från operation för stenar i urinblåsan. Tekniken beskrevs

246 Warholm 1895, s. $408-409$.

247 White 1893, s. 178; Harrison 1888, s. 121 - 122.

248 Shackley 1999, s. 777.

249 Warholm 1895, s. $408-409$.

250 Arthur Ferguson McGill (1846 - 1890) var en engelsk läkare som utbildade sig vid King College Hospital i London. Han flyttade sedan till Leeds där han innehade ett antal tjänster som läkare och senare kirurg, men även inom medicinsk undervisning. Han är mest känd för att vara den som etablerade suprapubisk prostatektomi. Arthur Fergusson McGill Collection, https://explore.library.leeds.ac.uk/special-collections-explore/615037 [sidan besökt 2019-1020]

${ }^{251}$ Harrison 1888, s. 121 - 122; Mansell Moullin 1892a, s. 1229. 
under 1860- och 1870-talen som en behandling av både prostatacancer och prostatahypertrofi, men det finns anledning att tro att den av misstag hade avlägsnat delar av prostatan vid blåsstensoperationer under flera århundraden. ${ }^{252}$ Mansell Moullin räknade till och med dessa "misslyckade" blåsstensoperationer som en operativ behandlingsmetod för prostatahypertrofi och kallade den "prostatectomy in the course of lithotomy". ${ }^{253}$

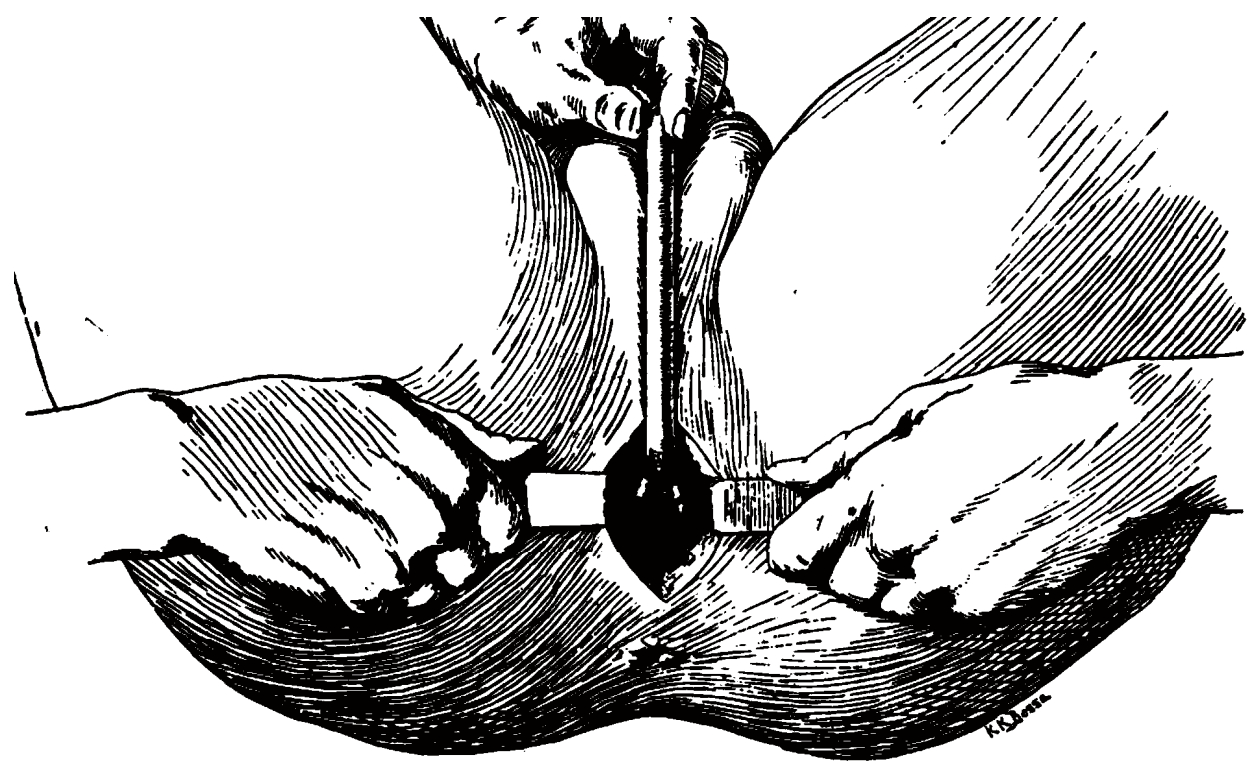

Bilden illustrerar förberedelserna för en perineal prostatektomi. Prostatan har dragits ner med hjälp av en sårhake i gummi för att kirurgen lättare ska kunna komma åt den. Källa: Parker Syms "Perineal Prostatectomy By a Special Method", del i Peter Johnston Freyer, Professor Alexander, W. Macewen, Jordan Lloyd, Parker Syms and Reginald Harrison, ”A Discussion On The Treatment Of Chronic Enlargement Of The Prostate", The British Medical Fournal, vol. 2, nr. 2184, nov. 8, 1902, s. 1498.

Helen Valier menar att det var Theodor Billroth som framförallt fick uppmärksamheten att riktas mot operationer som avlägsnade hela prostatan på

252 Shackley 1999, s. 779; White 1893, s. 176; Valier 2016, s. 54.

${ }^{253}$ Mansell Moullin 1892b, s. 1288. 
grund av cancer. Billroth publicerade 1869 Chirurgische Klinik. Zürich, 1860-1867, som innehåller en fallbeskrivning av en fullständig prostatektomi som beskrivs som lyckad. ${ }^{254}$ Det finns dock beskrivningar av försök av europeiska läkare att medvetet avlägsna hela prostatan redan i början av 1800-talet. ${ }^{255}$

År 1891 utförde den amerikanske kirurgen George Goodfellow (1855-1910) i Kalifornien den första perineala prostatektomin där hela prostatan avlägsnades medvetet. Han använde en så kallad intrauretral metod som medförde att kirurgen inte hade möjlighet att se prostatan, och metoden användes därför sällan. ${ }^{256}$ Richard Warholm kommenterade i en artikel 1895 att totalextirpation, att ta bort hela prostatan, hade föreslagits men att det enligt honom var ett alldeles för riskfyllt ingrepp för prostatahypertrofi. ${ }^{257}$ Oavsett vem som var först med att avlägsna hela prostatan och av vilken orsak så var det inte ett vanligt ingrepp under 1800-talet. Möjligheten att göra detta, och vilken operationsmetod som fungerade bäst, skulle dock få relevans när kastrering fått allt mer kritik och dessa operationsmetoder å sin sida förbättrats.

Den österrikiske kirurgen Leopold Ritter von Dittel (1815-1898) modifierade den perineala prostatektomin genom att placera patienten antingen liggande på sidan med uppdragna ben eller på mage med hängande ben. Han gjorde ett snitt från den yttersta svanskotan till mitten av ringmuskeln, runt anus och fram till hudsömmen i mellangården. På detta sätt gick det att komma åt

254 Valier 2016, s. 54. Shackley menar att det är troligt att de flesta operationer som genomfördes innan 1895 endast avlägsnade delar av prostatan, och inte hela som en prostatektomi idag innebär. Den första som genomförde ett medvetet avlägsnande av hela prostatan, enligt Shackley, var Eugene Fuller (1858 - 1930) från New York. Utan att ha någon möjlighet att se vad han gjorde av lägsnade han prostatan med fingret efter att ha klippt av den med en sax från fästet vid urinblåsan. Shackley 1999, s. 777.

255 Valier 2016, s. 54.

256 Shackley 1999, s. 779.

257 Warholm 1895, s. $408-409$. 
prostatan och skära ut kilformiga stycken ur de båda sidoloberna. Anledningen till denna modifiering var att Dittel ansåg att det inte var den så kallade mellanloben i prostatan som vållade de största problemen, utan sidoloberna, och de gick inte att komma åt med de tidigare metoderna. Dittels metod kallades prostatectomia lateralis, ungefär "sido-prostatektomi”..258 År 1892 bedömdes suprapubisk prostatektomi ha en mortalitet på cirka 20 procent. Det fanns ett stort motstånd mot prostatektomier på grund av övertygelsen att blåsatoni, en nedsatt förmåga att tömma blåsan, inte kunde botas genom att man avlägsnade det som orsakade urinrörsförträngningen. ${ }^{259}$ En operation skulle därför inte lösa patientens problem utan endast utsätta dem för en onödig fara.

Det fanns flera andra metoder där prostatan på olika sätt angreps med operationer. En av dem var perineal prostatotomi (prostatotomy), där man gick in genom mellangården men istället för att skära ut kilar eller delar av prostatan skar en kanal in i prostatan med ett skalpelliknande instrument, en bisturi. Till skillnad från en skalpell hade dock detta instrument en trubbig spets och snittet gjordes inifrån och ut och sedan kunde den kanal som skapats vidgas med fingret. Detta kunde även kombineras med ett permanent dränage in i prostatan. Ingreppet tycks i vissa fall ha medfört en minskning av trycket på urinröret. Denna metod hade en för tiden mycket låg mortalitet på 4,5 procent. ${ }^{260}$ Problemet med dessa operativa metoder var att de i bästa fall gjorde att patienten hade lättare att urinera under en kortare period. Problemen återkom dock i regel snart och ingreppen hindrade inte prostatan från att fortsätta växa. I värsta fall avled patienten av en kombination av en urinvägsinfektion eller njurbäckeninflammation som uppstått före operationen och den påfrestning och infektionsrisk som operationen innebar.

258 Warholm 1895, s. 408 - 409; Mansell Moullin 1892b, s. 1289.

259 Shackley 1999, s. 777.

260 White 1893 , s. $172,176-177$. 
År 1894 betraktades dock olika former av prostatektomi som formellt accepterade operationsmetoder vid prostatahypertrofi. De två största hindren för att metoden skulle bli allmänt accepterad var mortaliteten och att den inte behandlade alla de olika besvär patienterna hade med blåsan. Den höga mortaliteten tillskrevs av flera läkare de blödningar som uppstod runt prostatan och som var svåra att kontrollera, samt sepsis, en infektion orsakad av bakterier. Blåsproblematiken ansågs svår att göra något åt då den ofta berodde på påfrestningar på blåsan efter att patienten använt kateter vid urinering under många år: uttänjning, upprepade infektioner och förslappad muskulatur. ${ }^{261}$

I början av 1900-talet utvecklade den amerikanske kirurgen Hugh Young (1870-1945) och den franske kirurgen Robert Proust (1873-1935) en perineal metod som gav kirurgen möjlighet att se vad han gjorde. Framförallt åstadkoms detta genom att specialutformade sårhakar konstruerades och att patienten placerades i samma position som i en modern gynekologstol. Under det tidiga 1900-talet blev det den mest använda metoden i USA. Hugh Young och den brittiske kirurgen Peter Freyer publicerade statistik över mortaliteten för denna metod och kunde visa på att den låg under fyra procent för deras patienter. Deras samtida kollegor hade dock en mortalitet på 20-30 procent för samma metod. ${ }^{262}$

Det utvecklades en tvåstegsmetod för suprapubiska prostatektomier. År 1889 hade Hugh Young i Baltimore observerat att en svårt sjuk patients tillstånd förbättrats mycket efter en behandling med permanent kateter före operationen, så att prostatektomin kunde genomföras utan problem. ${ }^{263}$ Det första steget var en

\footnotetext{
${ }^{261}$ Jas. H. Nicoll, "A Method of Excising the Prostate", The Lancet, vol. 143, nr. 3685 (ursprungligen publicerad som volym 1, nr. 3685) april 14, 1894, s. 926.

262 Shackley 1999, s. 779.

263 Ibid, s. 778.
} 


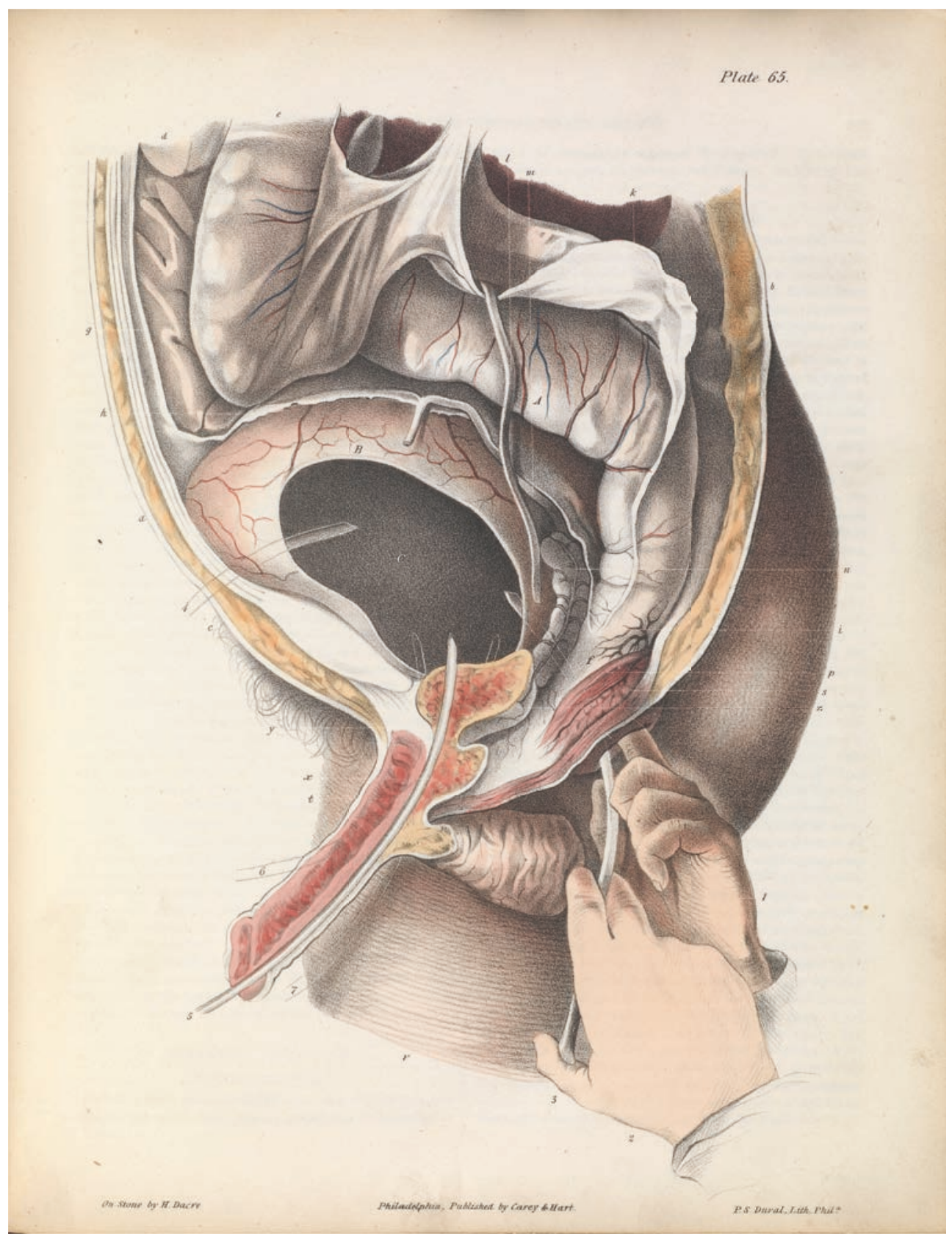

Plansch LXV. Kirurgisk anatomi för punktering av blåsan. Credit: Wellcome Collection. CG BY. På denna bild illustreras de tre vägar som främst användes för att punktera blåsan: genom buken, urinröret och rektum. Detta kunde användas vid till exempel total urinretention, eller för att placera ett dränage före eller efter operation vilket avlastade urinröret. 
suprapubisk cystostomi, att en kateter sattes genom bukväggen in i urinblåsan. Det avlastade hela urinsystemet från kateterisering, som innebar smärta, risk för skador och framförallt risk för infektioner. Om patientens kropp fick vila upp sig och läka ut till exempel urinvägsinfektioner och liknande så klarade den av en operation mycket bättre.

Kirurgerna var under denna period medvetna om att deras prostatapatienter ofta var för gamla och i alldeles för dåligt skick för några större ingrepp. Även om det i början av sjukdomsförloppet främst handlade om att avhjälpa urinretention så tillstötte med tiden allt fler komplikationer. Alla organ som på något sätt var inblandade $\mathrm{i}$ urineringsfunktionen drabbades av retentionen $\mathrm{i}$ form av urinvägsinfektioner, njurbäckeninflammationer och njurinflammationer, och till slut kunde patienten drabbas av sepsis (blodförgiftning) eller uremi (urinförgiftning). Att genomföra ett radikalt ingrepp på dessa patienter ansågs därför inte kunna medföra några större förbättringar, njurarna och blåsan var många gånger redan permanent skadade. ${ }^{264}$ Metoden att kastrera var ett försök att bota prostatahypertrofin tidigt och lösa dessa problem innan de uppstod. Som vi kommer att se var det metodens kanske mest lockande egenskap.

Massage av prostatan var en metod som beskrevs mer i förbigående. Metoden var palliativ och genomfördes genom rektum, men förbättringen som kunde upplevas efter massagen var kortvarig och enligt Ramm berodde den på att serum pressades ut ur prostatan så att det blev lättare att urinera under en kortare tid efteråt. 265

Det största problemet, som dock förbättrades något efter Joseph Listers upptäckt av antiseptiken och kanske i ännu högre grad efter utvecklandet av aseptiken, var risken för infektioner. Under större delen av 1800-talet hade man antagit att infektioner uppstod helt spontant eller till följd av miasma (dålig luft),

264 Warholm 1895, s. 410; White 1893, s. 172.

265 Ramm 1896, s. 5. 
smutsigt vatten eller otömda latriner, saker som jäste eller hade överhettats, eller dåligt blod. ${ }^{266}$ Redan i de tidiga mikroskopen hade man kunnat observera animacules - "små djur" - som rörde sig i olika kroppsvätskor. De tycktes finnas överallt, i alla människor och all mat, så först var det svårt att se dem som en förklaring till infektioner. Vidare studier av dessa små djur, som fick namnet bakterier, visade under 1870-talet att det fanns en stor mängd olika bakterier varav vissa orsakade infektioner och andra

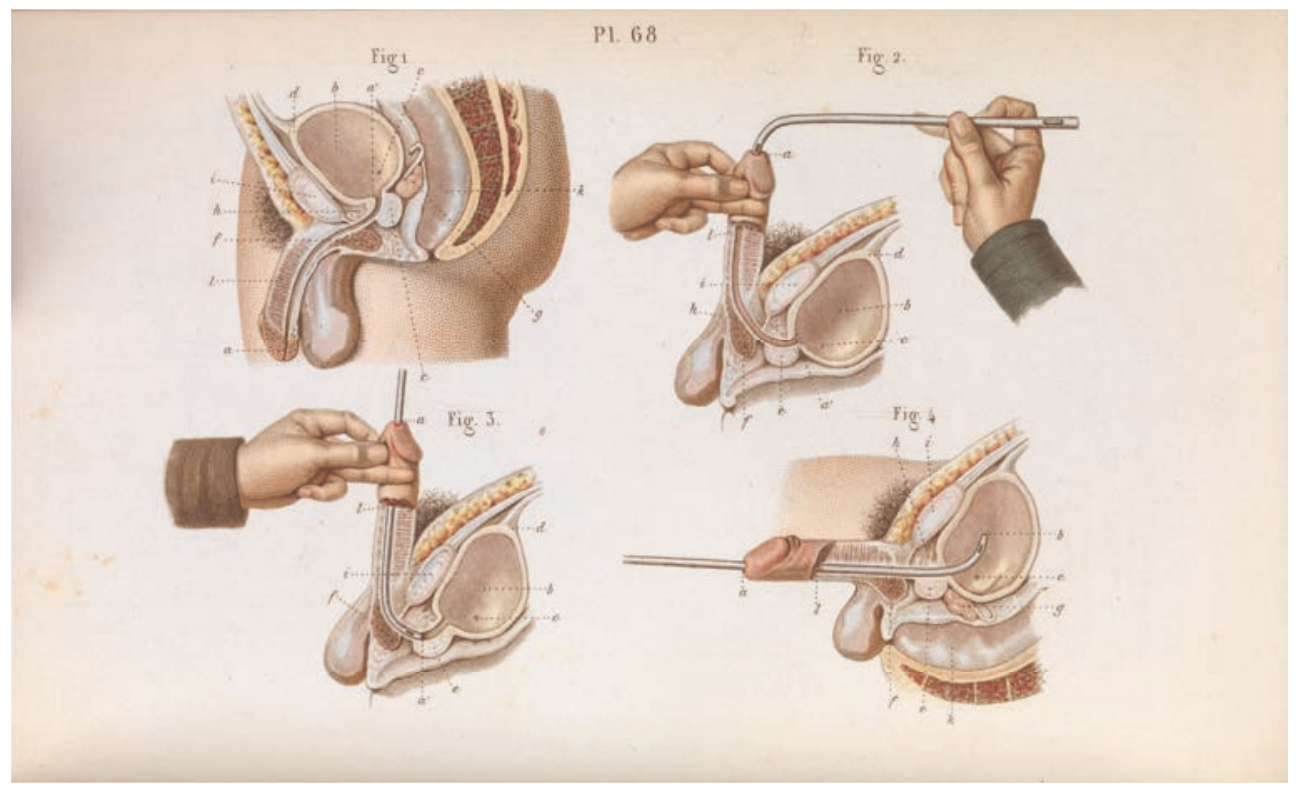

Plansch 68, Införande av kirurgisk kateter. Källa: Wellcome Collection. CC BY.

inte. Nu inleddes det stora arbetet med att klassificera bakterier, och under 1880talet identifierades bland annat kolerabakterien och tuberkelbakterien. ${ }^{267}$

Vid början av 1890-talet var läkare och kirurger alltså medvetna om att bakterier orsakade urinvägsinfektioner, njurbäckeninflammationer och andra

${ }^{266}$ För en utförligare genomgång av synen på sjukdomsorsaker innan bakteriologin se till exempel Drakman 2018.

267 Chapman 2016, s. $382-383,388-393$. 
följdsjukdomar som drabbade patienter med prostatahypertrofi. Vid kateterisering behövde katetern föras in i urinröret, ibland ända in till urinblåsan, flera gånger om dagen. Det var oftast bara en tidsfråga innan urinvägsinfektionen var ett faktum. ${ }^{268}$ Som Mansell Moullin uttryckte det: "the urethra is full of germs, and these are swept into the bladder every time an instrument is passed". 269

De absolut flesta patienter som led av prostatahypertrofi behandlade sig själva med någon sorts kateter i hemmet. För många av dem blev besvären aldrig större än att de med hjälp av kateter kunde tömma blåsan fullständigt, även om hypertrofin för många medförde smärta, trängningar och behov av att urinera ofta. Den ideala kateterpatienten beskrevs så här av en läkare 1896:

\begin{abstract}
If we have a thin hard man who has led an active healthful life, whose catheter goes in easily and smoothly, who has a clean home, and who is sufficiently intelligent to keep his catheter and the orifice of his urethra absolutely clean, or has someone who can do this, we have every condition which justifies being content with catheter life. ${ }^{270}$
\end{abstract}

Det är tydligt i materialet att patientens samhällsklass kraftigt påverkade chanserna för att en kateterbehandling skulle lyckas bra och inte leda till allvarliga komplikationer.

I vissa fall drabbades patienter med prostatahypertrofi av ett mycket farligare tillstånd, som Thompson beskrev som "att blåsan icke kan tömma sitt innehåll, men icke heller kan qvarhålla det. Kapaciteten minskas, och häftiga smärtor inställa sig, om blåsan blifver utspänd". ${ }^{271}$ Tillståndet kallas total urinretention,

268 Ramm 1896, s. 12 - 14; White 1893, s. 158; Charles William Mansell Moullin, "Some of the Recent Results of Orchotomy for Enlarged Prostate", The Lancet, vol. 147, nr. 3780 (ursprungligen publicerad som volym 1, nr. 3780) feb. 8, 1896c, s. 348.

${ }^{269}$ Mansell Moullin 1896c, s. 348.

${ }^{270}$ Maclaren 1896, s. 261.

271 Thompson 1875, s. 95. 
det var alltså omöjligt att urinera och i vissa fall även omöjligt att på ett enkelt sätt häva retentionen genom användning av kateter. Patienten behövde då uppsöka sjukhus eller läkare och få hjälp. När det var möjligt att igen använda kateter behövde patienten använda den mycket ofta, kanske flera gånger i timmen dygnet runt, eftersom smärtan och trängningarna blev så svåra. Det var förstås besvärligt och utmattande. ${ }^{272}$ Dödligheten vid kateteranvändning var i början av 1900-talet åtta procent under den första månadens användning. ${ }^{273}$ Flera läkare kallade katetern ett "tveeggat svärd" och skrev om de hemskheter som detta "kateterliv" innebar. ${ }^{274}$

Det fanns ingen effektiv behandling mot infektionerna, utan kroppen måste läka ut dem. Under tiden behövde patienten fortsätta att använda katetern, och ännu mer bakterier fördes in. ${ }^{275}$ Det var lättare för läkare att hålla instrumenten rena än för patienten att göra det $\mathrm{i}$ hemmet, även om de fick instruktioner om hur de skulle göra. För varje infektion drabbades patienten hårdare och risken för en ny infektion ökade, vilket med tiden ledde till att det bildades fosfathaltiga stenar i prostatan, till njurbäckeninflammationer eller till att njurarnas utsöndringsfunktion skadades - vilket i sin tur ledde till det som sir Henry Thompson kallade "death by slow torture". ${ }^{276}$

Eftersom urinvägsinfektioner kunde utvecklas till njurbäckeninflammation och leda till urinförgiftning, så behövde infektionerna behandlas innan ett

272 Thompson 1875, s. 95.

273 Shackley 1999, s. 778.

274 "Nordiska kirurgiska föreningens andra möte i Christiania den 11-13 juli 1895", Hygiea, band 57, augusti, 1895, s. 171; Fredrik Ramm, "Kastration for prostatahypertrofi", Nordiskt Medicinskt Arkiv, Årg. 1895, N:r 29, s. 2; John Rissler, "Några fall af prostatahypertrofi behandlade med kastration eller resektion af vas deferens", Hygiea, band 58, december, 1896, s. 672 .

275 Ramm 1896, s. 12 - 14; White 1893, s. 158; Mansell Moullin 1896c, s. 348.

${ }^{276}$ Mansell Moullin 1896c, s. 348. 
operativt ingrepp kunde genomföras. När patienter i mycket dåligt skick inkom till sjukhusen började läkaren därför ofta med att antingen föra in en ren, mjuk kateter för att dränera blåsan utan risk för att mer bakterier fördes in, eller så gjordes en så kallad fistel. Detta innebar att det gjordes ett hål i buken, ovanför den fog som sammanfogar höftbenen framtill på bäckenbenet, för att föra in ett dränage direkt i blåsan och tömma den på detta sätt. Ingrepp genomfördes ibland bara tillfälligt för att häva en retention som inte gick att kateterisera, men vissa patienter som var mycket dåliga fick ha fisteln under en längre tid för att urinvägsinfektioner eller njurbäckeninflammationer skulle läka ut. ${ }^{277}$ Kateterisering direkt av blåsan kunde även göras genom perineum och rektum. ${ }^{278}$ Förutom att angripa prostatan direkt eller genom palliativa åtgärder som kateterisering behandla den förstorade prostatan och de besvär den gav upphov till provades en metod där kärl runt prostatan knöts av. Det berövade prostatan blodtillförseln så att den förtvinade. Operationen kallades Biers metod efter den tyske kirurgen August Karl Gustav Bier (1861-1949). Problemet var att relativt stora kärl behövde knytas av eftersom det var svårt att komma åt de mindre, och eftersom operationen var en bukoperation var den riskfylld redan som den var. ${ }^{279}$

277 Ramm 1896, s. 14 - 15; Harrison 1888, s. 121.

278 Ramm 1896, s. 5.

${ }^{279}$ Meyer 1894, s. $44-45,51$. 

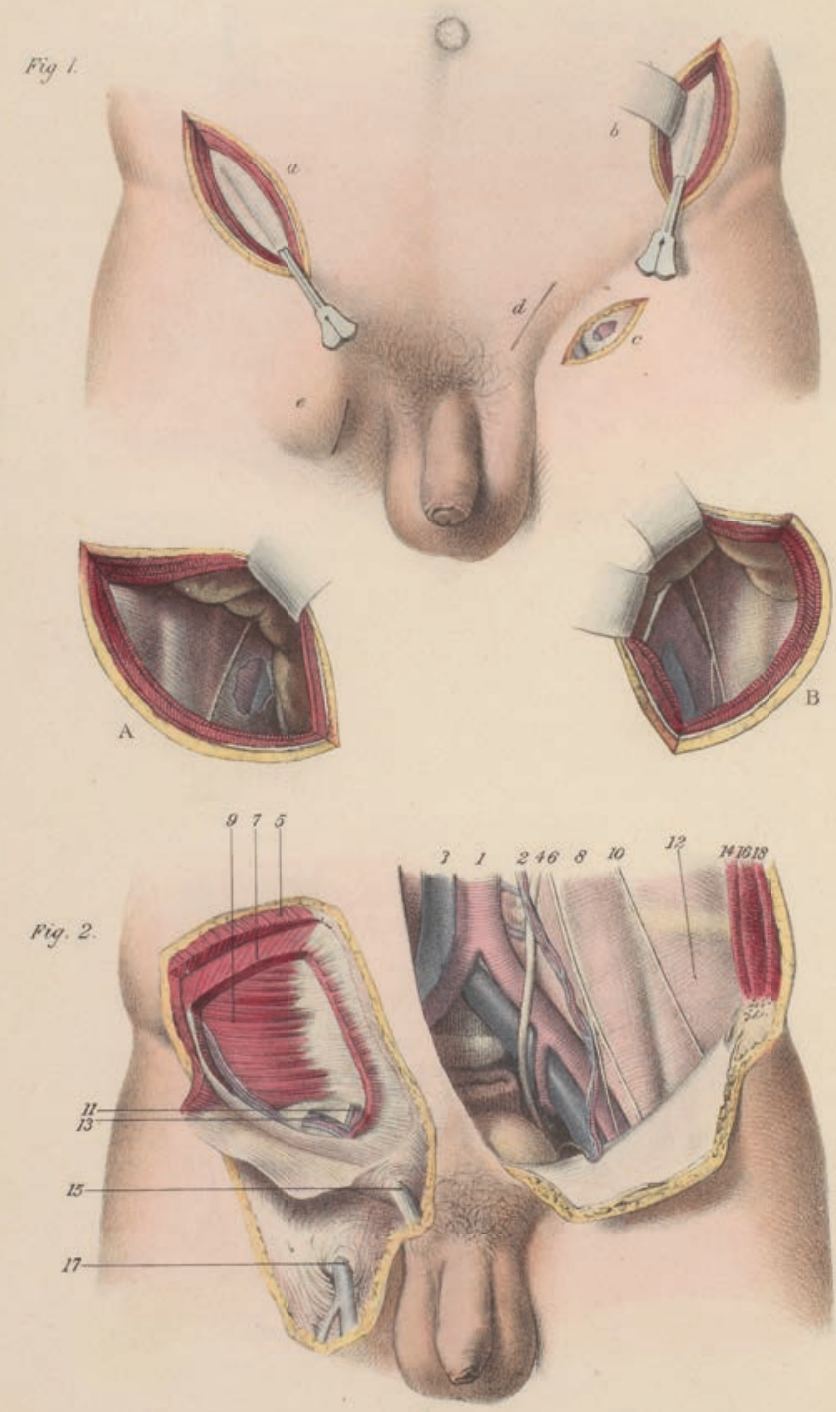

Plansch 6, Ligering av iliaca-artär och lårbensartär. Källa: Wellcome Collection. CC BY. Iliacaartären var det blodkärl som både Bier och Meyer provade att ligera (knyta av) för att behandla prostatahypertrofi. 


\section{Lanseringen och mottagandet av kastrering som behandlings- metod}

Castration will never be resorted to except in desperate cases, but there can be no doubt that many men dying deaths of lingering torture from catheterism and septic cystitis would be only too happy to purchase relief at such a cost. ${ }^{280}$

Mansell Moullin i The British Medical fournal 1894.

I augusti 1893 publicerades i Annals of Surgery en föreläsning som den amerikanske kirurgen William White hade hållit för The American Surgical Association samma år: "The Present Position of the Surgery of the Hypertrofied Prostate". Där presenterades för första gången förslaget att kastrera män som led av prostatahypertrofi. ${ }^{281}$ Den norske kirurgen Fredrik Ramm publicerade några notiser angående detta 1894 under rubriken Kastrationens betydning $i$ prostatahypertrofiens behandling. Ett manuskript till en längre text, den jag framförallt kommer att referera till, låg mer eller mindre klart i december 1895. I texten redogör Ramm för och diskuterar tre fall där han kastrerat män för att behandla prostatahypertrofi, två av dessa kastrerades under 1893. Den publicerades dock inte förrän 1896. ${ }^{282}$ White och Ramm hade båda på egen hand genomfört de djurexperiment som låg till grund för delar av argumentationen och presenterat sina resultat för kollegor under 1893. Ramm var den första kirurgen som kastrerade en man för att behandla prostatahypertrofi och rapporterade om resultatet. ${ }^{283}$

\footnotetext{
${ }^{280}$ Mansell Moullin 1894c, s. 976.

281 White 1893.

282 Ramm 1896, "Forord".

283 Ramm 1896, s. 30.
} 
Att föreslå kastrering som behandlingsmetod kan framstå som ologiskt och främmande, men i den medicinska diskurs där Ramm och White ingick var det inte det. För att förstå det behöver vi backa ytterligare ett århundrade. I slutet av 1700-talet började den skotske kirurgen John Hunter ${ }^{284}$ (1728-1793) intressera sig för delar av den manliga anatomin som hade med reproduktion att göra. Han ägnade sig åt komparativa anatomiska studier, vilka visade att alla delar av det manliga reproduktionssystemet på något sätt var beroende av testiklarna. Dessa resultat publicerade han i sin bok Observations on Certain Parts of the Animal Oeconomy 1792.

Effekten av kastrering på män var välkänd i vissa kretsar med tanke på att ingreppet hade förekommit länge: på hovmän i det forntida Kina, på afrikanska slavar för att kontrollera dem, på gossopraner för att skapa kastratsångare och på patienter som drabbats av till exempel abscesser (varbölder) på testiklarna. Hunter gick dock vidare och sökte en förklaring till varför effekterna uppstod. En av de slutsatser han drog av sina komparativa studier var att avlägsnandet av testiklarna fick prostatan att krympa och dess funktion att avta. 285

Varför föreslog inte Hunter kastrering som behandling mot prostataförstoring? Enligt Helen Valier berodde det dels på att även enkla ingrepp av oklar anledning kunde få dödlig utgång och dels på hur Hunter såg på sin roll som kirurg: han menade att kirurger i en tid av ökat självförtroende borde utöva återhållsamhet, speciellt när det rådde osäkerhet om orsaken till en åkomma och inte bara fokusera på resultatet. ${ }^{286}$ Det var först i slutet av århundradet som kastrering skulle vinna en kort period av acceptans, enligt Valier. ${ }^{287}$ Innan dess hade kastrering använts i ett fåtal fall för att behandla problem med prostatan.

${ }^{284}$ Inte att förväxla med hans bror William Hunter som specialiserade sig inom obstetrik men även skrev ett viktigt arbete om testiklarnas anatomi.

285 Valier 2016, s. $50-51$.

286 Ibid, s. $51-52$.

287 Ibid, s. 52. 
Utifrån Hunters resonemang kastrerade fransmannen Mercier 1859 en patient för att behandla urinblockering till följd av en förstorad prostata. ${ }^{288}$

Att Whites och Ramms förslag inte var så främmande som det först kan verka visar de reaktioner det väckte inom läkarkretsar. Mansell Moullin var en av de första som kommenterade förslaget, i en artikel i British Medical Fournal i september 1893, men istället för att kritisera det eller ifrågasätta var idén hade kommit från menade han att det redan framstått som en naturlig följd för många med tanke på de resultat som publicerats inom andra medicinska områden. Han hade själv året innan föreslagit kastrering för en patient, som hållit med i sak men ändå inte velat göra ingreppet, något som Mansell Moullin menade kanske var fullt naturligt. 289

Två veckor senare i samma tidskrift instämde Joseph Griffiths i att kastrering var den metod som framstod som rimlig för den som kände till prostatans förhållande till den sexuella funktionen. ${ }^{290}$ Flera läkare och kirurger började under 1893 att diskutera ingreppet och publicera tidigare fall av kastrering där prostatan påverkats. ${ }^{291}$ Från och med 1894 publicerades allt fler patientberättelser där läkare beskrev de fantastiska resultaten av kastrering vid prostatahypertrofi. De flesta av berättelserna är mycket lika varandra. ${ }^{292}$ Så här kunde förloppet se ut för en patient som sökte för problem med prostatahypertrofi:

288 Valier 2016, s. 52.

289 Mansell Moullin, "Castration in Enlargement of the Prostate", The British Medical Fournal, vol. 2, nr. 1707, sep. 16, 1893a, s. 655 .

${ }^{290}$ Joseph Griffiths, "Castration in the Enlargement of the Prostate", The British Medical Fournal, vol. 2, nr. 1709, sep. 30, 1893, s. 765.

291 Mansell Moullin 1893a, s. 655; Harrison 1893, s. 708 - 709; MacMunn 1893, s. 709; Mansell Moullin 1893b, s. 765; Joseph Griffiths, "Castration in the Enlargement of the Prostate", The British Medical fournal, vol. 2, nr. 1709, sep. 30, 1893, s. 765; Powell 1893, s. 1099.

292 Se till exempel: "An Epitome of Current Medical Literature", The British Medical Fournal, vol. 2, nr. 1755, aug. 18, 1894, s. 26; Mansell Moullin 1894c, s. 976; James Swain, "Castration for Prostatic Hypertrophy", The British Medical Journal, vol.1, nr. 1775, jan. 5, 
Den 25 oktober 1893 och tre månader framåt behandlades en patient på Alicia Hospital i Saint Augustine i USA för prostatahypertrofi. Patienten hade efter en tids mildare symptom, som nu förvärrats, lagts in på sjukhuset. Symptomen fortsatte att öka med upprepad urinretention, feber, smärta och urinträngningar och urinen innehöll var. Behandlingen bestod först av de vanliga alternativen med bland annat sköljningar av urinblåsan med olika lösningar. Detta hjälpte inte mycket och patienten fick flera akuta urinvägsinfektioner med septisk feber. Allt detta påverkade patientens sömn, eftersom han både plågades av smärtsamma och obehagliga symptom och dessutom behövde tömma urinblåsan upprepade gånger varje natt. Detta medförde en kraftig viktnedgång då han även tappade aptiten.

I detta läge besökte William White avdelningen och föreslog att patienten skulle kastreras. Efter konsultation och godkännande av både patienten och hans familj beslöts det att en kastrering skulle genomföras den 17 januari. Efter operationen behövde patienten använda en kateter den första veckan, men den andra veckan kunde han urinera utan den. Läkaren som opererat ordinerade ingen annan behandling efter operationen och patienten kunde skrivas ut efter sex veckor. Under sjukhusvistelsen hade patientens tillstånd förbättrats mycket med viktuppgång och minskning av alla de symptom han initialt uppvisat. Alla problem var inte borta men han behövde inte urinera lika ofta på nätterna och drabbades inte längre av upprepade urinvägsinfektioner eller urinretention. Patientens mentala tillstånd som innan operationen varit svagt och nedstämt var nu också mycket förbättrat. I maj 1894 skrev patientens bror ett brev till den behandlande läkaren och berättade att patienten nu hade en hälsosam vikt på

1895, s. 12 - 13; Faulds 1895, s. 974 - 975; Arthur Hunt, "Hypertrophy of the Prostate; Severe Cystitis; Double Castration; Recovery”, The Lancet, vol. 148, nr. 3814 (ursprungligen publicerad som volym 2, nr. 3814) okt. 3, 1896, s. $939-940$. 
81,5 kilo (6,5 kg mer än när han lades in på sjukhus) och inte hade några problem med att urinera eller någon smärta. ${ }^{293}$

Rapporter som denna satte igång en livlig debatt om kastrering som behandling mot prostatahypertrofi. Det publicerades ett stort antal beskrivningar av fall då patienter blev bättre, blev sämre eller avled efter operationen, och dessutom rapporterade läkare om positiva effekter på prostatahypertrofi när patienten egentligen kastrerats av en annan orsak. Läkaren Arthur Powell hade behandlat en 65-årig man som under flera månader kommit till the Belfast Royal Hospital i Nordirland när Powell arbetade där 1887. Patienten led av urinretention på grund av en förstorad prostata och utvecklade sedan en liten knöl i den högra testikeln. På grund av detta lades han in och kastrerades av en annan läkare, och återkom tre månader senare och rapporterade att han inte hade haft några urineringsproblem sedan operationen. Vid en rektal undersökning för att se om tumören kommit tillbaka i sädesledaren eller sädesblåsorna upptäckte Powell att prostatan hade krympt markant och att det var orsaken till att patienten inte längre hade några urineringsproblem. ${ }^{294}$

De läkare som var positivt inställda till kastrering som en behandlingsmetod för prostatahypertrofi uppmanade dock till en viss återhållsamhet. Framförallt White: redan två år efter att han hade föreslagit behandlingen manade han till försiktighet. Vurmen för kirurgiska ingrepp hade medfört att kirurger urskillningslöst opererade andra delar och organ, som urinröret, ovarierna och blindtarmen, enligt White. Denna tendens ville White motverka när det gällde den metod han själv föreslagit. Han ville inte bli skyldig till liknande attacker på testiklarna. ${ }^{295}$ Sedan 1893 hade metoden ökat i popularitet och redan 1894

${ }^{293}$ F. Fremont - Smith, "A Case of Obstructive Hypertrophy of the Prostate Treated by Castration", Annals of Surgery, vol. 20, 1894, s. $52-55$.

294 Powell 1893, s. 1099.

295 William White, "Castration as a Treatment for Hypertrophied Prostate", The British Medical fournal, vol. 1, nr. 1775, jan. 5, 1895a, s. 50. 
menade Mansell Moullin att man måste erkänna att kastrering gjorde att den förstorade prostatakörteln krympte, och att detta inte bara var en vaskulär skillnad, en skillnad i blodflödet, som vissa hävdade, utan att det faktiskt var själva vävnaden som atrofierade. ${ }^{296}$ Han fick stöd av flera yrkeskollegor. ${ }^{297}$

Under rubriken "The Annus Medicus 1895" i The Lancet i december 1895 stod det att läsa:

The treatment of enlargement of the prostate by castration is on the whole growing in favor, but it is by no means rare for deaths to follow the operation; this is probably to be explained by the very diseased condition of the kidneys usually present in longcontinued prostatic enlargement. ${ }^{298}$

När Borelius publicerade sin artikel 1896 var han av den åsikten att det var under föregående år som man i Europa hade börjat uppmärksamma metoden, och det hade han rätt i att döma av rapporterna i läkartidskrifterna. ${ }^{299}$ En läkare skrev 1895 att det var varje kirurgs ansvar att på ett ärligt sätt uppmana till användningen av alla operationer som kunde vara effektiva för att göra slut på det fruktansvärda lidande som patienter fick utstå. ${ }^{300} \mathrm{En}$ annan läkare skrev att han när han hade tillfrågats om vilka behandlingsalternativ som han ansåg vara användbara vid prostatahypertrofi hade svarat att han föreslog suprapubisk

296 Mansell Moullin 1894c, s. 976.

297 Swain 1895, s. 13; Hurry Fenwick, "Observations on the Effects of Double Castration (White's Operation) Upon the Enlarged Prostate", The British Medical Fournal, vol. 1, nr. 1785, mar. 16, 1895b, s. 579.

298 “The Lancet: London: Saturday, December 28, 1895”, The Lancet, vol. 146, nr. 3774, (ursprungligen publicerad som volym 2, nr. 3774), dec. 28, 1895, s. 1631.

299 Borelius 1896, s. 425.

300 "Epitome of Current Medical Literature", The British Medical fournal, vol. 1, nr. 1777, jan. 19, 1895a, s. 10. 
prostatektomi, perineal prostatektomi, galvano-kaustiskt avlägsnande av hindret och kastrering, och:

From the evidence then before me I concluded that treatment by castration seemed the most promising method of all, the risk being probably least, the prospect of cure greatest and suitable for the case of a patient 60 years of age. ${ }^{301}$

En annan läkare skrev samma år:

From the commencement of "catheter life" to the death of the patient from bladder or kidney mischief, hypertrophy of the prostate gland is associated with so much worry and pain and danger that we should gladly welcome any means which offer relief from this distressing condition. ${ }^{302}$

Det var inte bara White som efter några år började uppmana till viss återhållsamhet. Det publicerades så många fantastiska rapporter att metoden framstod som den mirakulösa behandling många hoppats på. Samtidigt var många läkare och kirurger tveksamma till att det verkligen kunde stämma. Både läkare och patienter uppmanades att inte ha för stora förväntningar och inte förvänta sig så snabba förbättringar som hade rapporterats i vissa fall. Men de uppmanades också att inte heller se kastrering som en universallösning för alla stadier av urineringsproblem orsakade av prostatan. ${ }^{303}$

Under 1895 började de rapporterade fallen bli så många att man kunde sammanställa dem och dra statistiska slutsatser. I november 1895 hade över 100

301 Jennings 1895, s. 171.

302 Swain 1895, s. 12.

${ }^{303}$ Fenwick 1895b, s. 578. 
kastreringar för prostatahypertrofi genomförts och rapporterats. ${ }^{304} \mathrm{I}$ de fall där symptomen förbättrats hade behandlande läkare konstaterat att prostatan hade minskat i storlek. Läkarna var dock begränsade till att göra kliniska undersökningar för att bedöma en eventuell storleksförändring, alltså rektal undersökning med fingret. I endast tre av de kända fallen hade en mikroskopisk undersökning av prostatan gjorts post mortem. ${ }^{305}$

Det var svårt att avgöra om prostatans minskning berodde på atrofi av körteln eller om det var något annat, som minskad blodstockning eller liknande, som fick prostatan att kännas mindre. Det diskuterades hur snart efter operationen man kunde förvänta sig att se en vävnadsförändring i prostatan. Experiment på djur och kastrering av män med friska prostator visade att det kunde ta dagar eller veckor innan en atrofiering kunde konstateras, inte timmar som White hävdat. ${ }^{306}$

Det rapporterades i British Medical fournal om böcker och artiklar om kastrering som behandlingsmetod som publicerats, framförallt i Tyskland och Frankrike. I stort uppgav dessa läkare och kirurger samma sak som de brittiska och amerikanska. Enligt en artikel 1896 hade den tyske läkaren Peter von Bruns samlat in uppgifter om 148 fall där män kastrerats för prostatahypertrofi och konstaterat att i 83 procent av fallen hade prostatan minskat i storlek efter ingreppet. Han tillskrev minskningen en utebliven nervpåverkan från testiklarna. Vid denna tidpunkt konstaterades det att dessa operationer i kombination med "experimentella undersökningar" kunnat visa att det fanns en nära fysiologisk

304 Charles William Mansell Moullin, "On Some of the Immediate Results Produced by Castration in Cases of Enlarged Prostate”, The Lancet, vol 146, nr. 3770 (ursprungligen publicerad som volym 2, nr. 3770) nov. 30, 1895c, s. 1347 - 1348.

305 Mansell Moullin 1895c, s. 1347.

306 Mansell Moullin 1895c, s. 1347 - 1348; "An Epitome of Current Medical Literature", The British Medical Journal, vol. 1, nr. 1828, jan. 11, 1896a, s. 6. 
påverkan mellan prostatan och testiklarna. Prostatans utveckling och friska funktion var beroende av testiklarna. ${ }^{307}$

von Bruns konstaterade, som brittiska och amerikanska läkare gjort tidigare, att resultatet av operationen bland annat berodde på vilka besvär patienten hade, vilken form av förstoring av prostatan det rörde sig om (fibrös, glandulär och så vidare) och hur allvarlig och långvarig retentionen varit. Ett ingrepp tidigt i sjukdomsförloppet gav oftast bättre resultat, och den som hade en mycket uttänjd blåsa skulle troligtvis även efter operationen behöva en kateter för att kunna tömma blåsan helt. von Bruns noterade att även de riktigt gamla patienterna ibland motsatte sig ingreppet på grund av att de inte ville bli kastrerade, och att det fanns rapporter om nervös depression och mental apati som följde efter kastreringen. Därför yrkade han på en lång och noggrann utredning av ingreppet innan något slutgiltigt beslut fattades. Han bedömde dubbel kastrering som den mest framgångsrika behandlingen av prostatahypertrofi i ett tidigt skede av sjukdomsförloppet. ${ }^{308}$ En annan tysk läkare, Hermann Kümmell, konstaterade precis som sina brittiska och amerikanska kollegor att en fördel med kastrering var att patienterna inte behövde sövas utan endast bedövas. De behövde inte heller vara sängliggande en längre tid efter operationen vilket var särskilt viktigt för äldre och svaga patienter. ${ }^{309}$

Från 1896 växte dock kritiken mot kastrering. Kritiken tog fasta dels på de fall av negativ psykisk påverkan som det började komma in rapporter om, dels på tvivel gällande om prostatan verkligen krympte efter kastrering när den hade varit förstorad. Behandlingsmetoden kvarstod som ett alternativ under 1900-talets första år men försvann sedan. Dessutom visade statistik att resultaten i längden

\footnotetext{
307 "An Epitome of Current Medical Literature", The British Medical Fournal, vol. 1, nr. 1842, apr. 18, 1896b, s. $61-62$.

308 "An Epitome..." 1896b, s. 61 - 62.

309 "An Epitome of Current Medical Literature", The British Medical Journal, vol. 2, nr. 1807, aug. 17, 1895b, s. 25.
} 
inte var så goda som man förväntat sig - hos många patienter återkom problemen eller så fortsatte de inte att förbättras efter de initialt lovande resultaten. Slutligen gjorde framstegen inom antiseptiken både att kateteranvändningen blev mycket säkrare och att prostatektomierna kunde genomföras på säkrare sätt med en mycket lägre dödlighet. Dessa operationer visade sig i längden ge bättre resultat än kastrering och patienterna överlevde i högre grad.

I kommande kapitel kommer jag att djupdyka ner i fyra områden som var viktiga för kunskapsproduktionen om kastrering som behandlingsmetod för prostatahypertrofi och skapandet av prostatan, och även testiklarna, som kunskapsobjekt. Det första är den misslyckade argumentationen för en analogi mellan uterus och prostata. Det andra är jämförelserna mellan män som var födda med avvikelser och som under livet drabbats av olyckor eller genomgått operationer som påverkat testiklarna. Det tredje är djurexperimenten som användes för att bringa klarhet $\mathrm{i}$ frågan och den erfarenhet som kom av att kastrera kvinnor och män av olika anledningar. Och det fjärde är slutet på historien: hur kastreringen spelade ut sin roll som behandling mot prostatahypertrofi. Nästa kapitel kommer alltså att djupdyka ner i analogin mellan uterus och prostatan eller mellan uterusmyom och prostatahypertrofi. 


\section{Till kvinnans avbild?}

Som vi sett i kapitlen innan hade prostatan och prostatahypertrofi börjat intressera läkare allt mer under 1800-talet. Det fanns ett flertal behandlingsmetoder, även om ingen av dem ännu urskilt sig som speciellt verksam. Det bästa, och i många fall säkraste, var att hoppas på att kateteranvändning fungerade så länge som möjligt. Att kunna erbjuda en relativt ofarlig men mycket effektiv behandling framstod i detta läge som lockande.

Detta kapitel handlar om ett av huvudargumenten för att föreslå kastrering som behandling för prostatahypertrofi: analogin mellan uterus/uterusmyom och prostatan/prostatahypertrofi. Det gjordes även andra jämförelser med kvinnokroppen för att förorda kastrering som behandlingsmetod. Dels jämfördes kopplingen mellan uterus och ovarier med kopplingen mellan prostatan och testiklarna, dels jämfördes det kvinnliga klimakteriet med ett möjligt manligt klimakterium. Den aktuella perioden beskrivs av flera historiker som mycket konservativ när det gällde ingrepp på de manliga genitalierna och könskörtlarna. Så hur lyckades White och Ramm, med flera, föra fram kastrering som en behandlingsmetod mot prostatahypertrofi?

Thomas Laqueur talade om testiklarnas "helighet" jämfört med ovarierna, som opererades bort i mycket större utsträckning, ${ }^{310}$ Chandak Sengoopta gick på samma linje beträffande testiklarnas status runt sekelskiftet $1900 .{ }^{311}$ Likaså gjorde Timothy O’Neill beträffande kastrering mot prostatahypertrofi. ${ }^{312}$ Andra

310 Laqueur 1992.

311 Sengoopta 2006.

312 O’Neill 2003. 
historiker har förvisso argumenterat för att de manliga könskörtlarna och genitalierna inte varit så fredade från ingrepp som gjorts gällande, bland annat har Robert Darby uppmärksammat manlig omskärelse på 1800-talet och i början av 1900-talet. ${ }^{313}$ Samtidigt diskuterades manlig kastrering som ett straff, eller ett sätt att bota eller hindra vissa grupper från att fortplanta sig, i slutet av 1800-talet och början av 1900-talet. ${ }^{314}$ Men i kontrast mot den tilltagande användningen av kvinnlig kastrering från 1800-talets mitt och framåt hade de manliga testiklarna till stor del lämnats ifred. ${ }^{315}$

Kastreringen av kvinnor erbjöd dock en möjlighet att argumentera för manlig kastrering vid prostatahypertrofi. Urologin var strax före sekelskiftet 1900 ännu i sin linda och hade inte etablerat sig som en specialistinriktning, men det fanns en annan specialistinriktning som hade intresserat sig för könskörtlarnas kopplingar till sexuella organ: gynekologin. Här hämtade man kliniska erfarenheter och teoretiska hypoteser för att förklara varför kastrering av män med till synes friska testiklar skulle kunna bota eller lindra prostatahypertrofi.

När Borelius 1896 publicerade sin första artikel på ämnet kastrering för prostatahypertrofi sammanfattade han argumenten bakom denna behandlingsmetod på följande sätt:

Det var icke iakttagelser öfver att prostatan hos kastrater eller personer med atrofiska, ektopiska testiklar faktiskt är atrofierad, eller tillfälliga iakttagelser, att kastration, företagen af annan orsak, kommit symptomen af en prostatahypertrofi att minska eller försvinna, ej heller var det kännedomen om det faktum, som lär vara kändt för slagtare, att prostatan hos vissa djur, som i ungdomen kastrerats, nästan saknas, som ledde deras tankegång i denna rigtning, det var på en annan väg de kommo dit. Det var den af gammalt kända och framhållna likheten i rent

313 Darby 2005a; Darby 2005b, s. $283-319$.

314 Dale 2010; Bryant 2012, s. 237 - 254.

315 Frampton 2018; Nilsson 2003; Moscucci 1990. 
patolog. anatomiskt hänseende mellan en hypertrofisk prostata och en myomatös uterus, som gaf anledningen. ${ }^{316}$

Det var först och främst denna likhet eller analogi som William White och Fredrik Ramm lyfte fram i sina artiklar. De pekade även på de kliniska erfarenheter som fanns av olika avvikelser som saknade eller skadade testiklar och kastrering av andra orsaker, på djurexperiment och på erfarenheter av djurhållning. Dessa argument har fått egna kapitel längre fram i avhandlingen.

Borelius fann hypotesen om likheten mellan uterusmyom och prostatahypertrofi så pass intressant att han försökte "att något närmare skärskåda hållbarheten af detta resonemang". ${ }^{317}$ Uterusmyom hade behandlats med kvinnlig kastrering (ovariektomi), och behandlingen bedömdes som delvis framgångsrik. ${ }^{318}$ Att två organ sågs som analoga innebar under denna period att man såg dem som varandras motsvarigheter i den kvinnliga och manliga kroppen. De förutsattes dessutom ha en gemensam embryologisk grund, det vill säga ha utvecklats från samma strukturer i fosterstadiet. Ibland användes ordet "homologa", men utifrån materialet är det svårt att avgöra om det var någon skillnad mellan begreppen; ofta tycks de ha använts som synonymer.

Om uterusmyom hos kvinnor var samma sjukdom som prostatahypertrofi hos män så borde ovariernas påverkan på uterusmyom vara densamma som testiklarnas påverkan på prostatahypertrofi. Kunde det ena behandlas framgångsrikt med kastrering så borde detsamma gälla för det andra. Redan när denna idé lanserades 1893 av William White och Fredrik Ramm bemöttes den med protester från embryologer och andra läkare. Borelius sällade sig, efter sin mer noggranna undersökning av resonemanget, till dem som bedömde denna vetenskapliga berättelse som tveksam och icke trovärdig.

316 Borelius 1896, s. 424.

317 Borelius 1897a, s. 284.

318 Ibid. 


\section{Analogin mellan uterus och prostata}

White och Ramm presenterade en analogi mellan antingen uterus och prostata eller mellan uterusmyom och prostatahypertrofi. Att söka efter analogier och se dem som en källa till kunskap är något man har gjort länge inom medicinen. Aegidius Albertinus (1560-1620) såväl som den svenske anatomen, astronomen och botanikern Olof Rudbeck d. ä. (1630-1702) och Carl von Linné (1774-1778) sökte efter analogier i naturen. ${ }^{319}$ När det gäller mer specifikt analogier mellan manliga och kvinnliga könsorgan hade Galen redan under antiken beskrivit förhållandet mellan kvinnliga och manliga könskörtlar. ${ }^{320}$ I Sverige hade Anders Retzius (1796-1860) under 1820-talet sammanfattat och spridit tankar om analoga organ, framförallt om den embryologiska utvecklingen, som beskrivits av Caspar Friedrich Wolff (1733-1794) och Johannes Müller (1801-1858). Det som framhölls av dessa var embryots ursprungliga tvåkönighet och hur de olika delarna av genitalierna motsvarade varandra hos kvinnor och män, och bland dessa testiklar och ovarier. ${ }^{321}$ Standardverket om könsorganen under 1800-talet var, enligt Robert Darby, Kobelts Die männlichen and weiblichen Wollusts-Organe des Menschen und einiger Saugethiere ("De hanliga och honliga njutningsorganen hos människan och några däggdjur”) som utkom 1844. I denna bok hävdade Kobelt bland annat att "the female organs are exactly analogous to the male". ${ }^{322}$

Det var alltså ingenting nytt varken att leta efter analogier i naturen eller att hävda att det fanns analoga organ hos kvinnor och män. Och liksom många andra läkare under perioden lutade sig Fredrik Ramm och William White mot en äldre auktoritet. När de började argumentera för en analogi mellan uterus och prostatan och uterusmyom och prostatahypertrofi hänvisade de främst till den

\footnotetext{
319 Bondestam 2010, s. 50, 58.

${ }^{320}$ Laqueur 1992, s. 25 - 35; Bondestam 2010, s. 136.

321 Bondestam 2010, s. $166-167$.

322 Citerad i Darby 2005a, s. 122.
} 
franske kirurgen Alfred Velpeau, som hade konstaterat en analogi mellan dessa två sjukdomstillstånd. Velpeau såg en likhet mellan tumörerna i de två organen, vilka han, i likhet med läkarna och kirurgerna i kastreringsdebatten, kallade lobuli.

Velpeaus analogi inspirerade inte bara White och Ramm till behandlingar för prostatahypertrofi utan även August Bier (1861-1949), som vid denna tid var förste assistentläkare vid den kirurgiska kliniken i Kiel. Bier valde dock en annan metod, som hade använts för behandling av uterusmyom och andra förstorade organ: ligering av de tillförande kärlen. Han knöt av arteria iliaca interna för att hindra blodtillförseln till prostatan. ${ }^{323}$

Ramm och White anslöt sig båda till körtelteorin: att prostatahypertrofi berodde på tillväxten av rörformiga adenom i prostatan. Både adenom och myom är godartade tumörer, vilka namngetts i slutet av 1800-talet utifrån definitionen att adenom uppstår i körtelvävnad och myom i muskelvävnad. Uterusmyom växer alltså fram ur livmoderns muskelvävnad och prostataadenom ur prostatans körtelvävnad. ${ }^{324}$ Redan här kan vi se en glidning, något som inte var riktigt konsekvent, i den vetenskapliga berättelse som Ramm och White måla upp: de tumörer de hävdade var analoga hade helt olika ursprung.

Det hindrade inte Ramm från att notera fler likheter mellan uterus och prostatan. Flera läkare hade kunnat se att prostatan hos äldre män, framför allt om den inte var förstorad, genomgick en senil atrofiering, och läkare som studerade prostator i mikroskop tyckte sig kunna se detta även på cellnivå. Ramm menade att uterus hos äldre kvinnor genomgick en liknande, eller motsvarande, atrofiering. Han menade även att förstoringen av organen skedde på liknande sätt, antingen genom en jämn volymökning av hela prostatan eller hela uterus, eller till följd av svulster. ${ }^{325}$ Både Ramm och White hävdade i sina tidiga artiklar att uterus

\footnotetext{
323 Warholm 1895, s. 414.

324 Adenoma https://www.lexico.com/en/definition/adenoma, myoma https://www.lexico.com/en/definition/myoma

325 Ramm 1896, s. 29.
} 
och prostatan hade samma embryologiska ursprung. Det dementerades dock omedelbart av tidens embryologer - så omedelbart att Ramm och White har med deras protester i sina respektive första artiklar i ämnet. Trots detta skulle de båda länge hålla fast vid denna hypotes. ${ }^{326}$

Ramm och White utgick från samma påstådda analogi, men Ramm främst från Velpeaus iakttagelser och White främst från Henry Thompsons vidareutveckling av Velpeaus analogi. ${ }^{327}$ White citerade denna vidareutveckling i sin helhet i sin första artikel i ämnet:

The prostatic vesicle is the analogue of the sinus genitalis in the female - the uterine and vaginal cavities; the structure of the prostate and of the uterus is strikingly similar, and would be almost identical if the tubular glands found in the inner walls of the uterus were prolonged into its substance; the histology of the growths themselves is equally similar, differing chiefly in the predominance of the glandular element in the prostatic tumors; the varieties of the growths, from small encapsulated tumors, easily shelled out, or polypoid growths intimately connected with the uterus or prostate up to the enormous growths which far exceed the original bulk of the organ itself, are identical; or there may be in either case a general hypertrophic enlargement affecting the whole organ. ${ }^{328}$

Vad var det Thompson hade sett när han studerade dessa organ? För det första talar han om två strukturer, the prostatic vesicle och sinus genitalis, som är svåra att identifiera idag, men med ledning av hur olika läkare diskuterar denna struktur i materialet kan man dra slutsatsen att prostatic vesicle är den del som vissa kallade prostatic utricle eller sinus prostaticus och som Borelius kallade uterus masculinus.

${ }^{326}$ Ramm 1896, s. 31 - 32; White 1895d, s. 8 - 9; Ramm 1895, s. 3.

327 Ramm 1896, s. 28; White 1893, s. 156.

328 White 1893, s. 156. White skriver nästan ordagrant samma sak om analogin i White 1895d, s. 8. 
Formuleringen "the uterine and vaginal cavities" kan tyda på att Thompson såg en likhet mellan håligheterna $\mathrm{i}$ uterus och prostatan. Men framförallt var det körtlarna i uterus och prostatan som Thompson såg likheter emellan. Enligt honom var de närmast identiska, både vid makroskopisk och mikroskopisk undersökning, och det var detta som låg till grund för den analogi som Thompson uppfattade mellan organen.

Det var tack vare mikroskopet som Thompson kunde studera vävnadernas uppbyggnad och jämföra dem med varandra, men även med blotta ögat kunde han se likheter. Mikroskopet och ögat går direkt att identifiera som de apparater som ingick i intra-aktionen som skapade prostatahypertrofi och uterusmyom som analoga. Men i detta fall tycks det vara så att mikroskopet och seendet skapade dessa som två olika sjukdomar som vid närmare betraktande inte var speciellt lika. I kombination med obduktionen kunde läkare och kirurger makroskopiskt och mikroskopiskt studera dessa olika strukturer och se skillnader och likheter.

Thompsons berättelse om analogin mellan uterus och prostata och mellan uterusmyom och prostatahypertrofi innehöll ett antal svagheter och en hel del om. För det första påstod han inte att hela uterus och prostatan var analoga, endast de delar av prostatan och uterus som ansågs utvecklas ur samma embryologiska strukturer. För det andra menade han att organen var slående lika, men en del av denna likhet bestod i att om gångarna från körtlarna i uterus sett likadana ut så hade de varit närmast identiska. För det tredje var utväxterna mycket lika om man bortsåg från att de i prostatan innehöll mycket mer körtelvävnad. Likheten tycks mest ha bestått i att tumörerna för blotta ögat framstod som väldigt lika. Började man undersöka tumörerna och organet eller körteln som de växte fram ur så visade det sig att det fanns en hel del skillnader.

Grunden för analogin mellan uterus/uterusmyom och prostatan/prostatahypertrofi var alltså från början minst sagt svag. Eller för att uttrycka det annorlunda: de agentiella snitten hade inte slutgiltigt gjorts. Det var fortfarande oklart hur dessa två sjukdomar förhöll sig till varandra och, som jag visat i kapitel 
fem, var det fortfarande oklart hur framförallt prostatahypertrofi skulle definieras och avgränsas för att bli en diagnos att studera.

\section{Det embryologiska ursprunget}

Ramm och White byggde en stor del av sin argumentation på dessa, av Velpeau och Thompson, utpekade likheter mellan uterus, prostata, uterusmyom och prostatahypertrofi. White garderade sig något redan i sin artikel 1893 genom att påpeka att han inte hävdade att det förelåg en absolut homologi mellan uterus och prostatan. I texten inleder han med att föreslå en analogi mellan organen, för att sedan diskutera kritiken och slutligen hamna i konstaterandet att uterus och prostatan utgjordes av samma sorts vävnad och drabbades av samma sjukliga utväxter vid samma tidpunkt $\mathrm{i}$ livet. ${ }^{329}$ White påpekade att om denna likhet förelåg så gav det ingen fullständig förklaring till varför prostatahypertrofi uppstod. ${ }^{330}$

I den artikel som publicerades 1896, och som hade legat klar sedan 1895, skrev Ramm att de flesta menade att uterus och prostata hade olika embryologiskt ursprung, men att det fanns forskare inom embryologi som var av en annan mening. Bland annat menade en läkare att hans studier visat att prostatans muskler övergick direkt i sinus prostaticus, en struktur som alla var överens om hade sitt ursprung i de müllerska gångarna, precis som uterus. ${ }^{331}$

Samtidens syn på embryots utveckling hade stor inverkan på resonemangen om analogier. Samma år som White och Ramm presenterade sitt förslag om kastrering som en behandling mot prostatahypertrofi hölls världsutställningen i Chicago. Där kunde besökarna beskåda en fantastisk utställning av vaxmodeller

329 White 1893, s. 186.

330 Ibid, s. 156.

331 De wolffska och müllerska gångarna är embryonala strukturer som hade identifierats i det mänskliga embryot av Caspar Friedrich Wolff (1733 - 1794) en av grundarna av embryologi, och Johannes Müller (1801 - 1858). Som strukturer var de alltså inte nya inom embryologin. Ramm 1896, s. 32. 
av embryon och deras utvecklingsstadier - embryon och larver från så skilda arter som sjöstjärnor, skalbaggar, människor, grodor och öring. Vaxmodellerna föreställde olika utvecklingsstadier och besökarna kunde se i vilken ordning organen utvecklades. Vad dessa modeller illustrerade var en utveckling från enkla embryonala former via mellanliggande stadier till en komplex kropp. ${ }^{332}$

Detta var modeller som användes vid vetenskapliga utbildningar. De flesta av dem tillverkades i Tyskland och exporterades till andra delar av världen. ${ }^{333}$ Sedan mitten av 1800-talet hade embryologin etablerats så mycket att professorer gav speciella föreläsningar i ämnet och det gavs ut läroböcker, och vid undervisning i användningen av mikroskop tränade studenterna på att studera embryologiskt material. ${ }^{334}$ Vid 1890-talets början var embryologin ett etablerat fält. En av de viktiga aspekterna för debatten kring analogin mellan uterusmyom och prostatahypertrofi var embryologernas åsikt att enkla strukturer i embryot gav upphov till mer komplexa strukturer vilket innebar att det urogenitala systemet hos kvinnor och män nu allt mer sågs som utvecklat ur samma embryologiska strukturer.

Av de argument som White och Ramm förde fram i sina artiklar framgick att de inte var överens om vad som utvecklades ur vilka strukturer. Ramm med flera menade att sinus prostaticus, en struktur i mitten av prostatan även kallad uterus masculinus av bland andra Borelius, eller prostatic vesicle av White, utvecklades ur de müllerska gångarna precis som uterus. Han menade även att andra delar i prostatan, som prostatans stroma, alltså den mjuka bindväven, och annan bindväv utvecklats ut de müllerska gångarna. ${ }^{335}$ Han nämnde aldrig de wolffska gångarna i sina artiklar om kastrering vid prostatahypertrofi. White hävdade å sin sida att prostatans glandulära delar utvecklades ur en struktur som kallas urogenitalt sinus

\footnotetext{
332 Hopwood 2013, s. 1.

333 Ibid, s. 3.

334 Ibid, s. 33.

335 Ramm1895, s. 3.
} 
och prostatans stroma från de primitiva könssträngar som omgav de wolffska gångarna, men att uterus utvecklades från de müllerska gångarna och prostatic vesicle utvecklades ur urogenitalt sinus. ${ }^{336}$

Det framgår inte tydligt i dessa texter vad tidens embryologer och läkare faktiskt ansåg sig veta om dessa strukturer eller vad White och Ramm bygger sina olika åsikter på. Den enda som nämns är att embryologerna ansåg att embryot var tvåkönat fram till nionde veckan, först därefter utvecklades det till ett manligt eller kvinnligt foster. ${ }^{337}$ Det är klart att White och Ramm hävdar att delar av genitalorganen utvecklas ur de müllerska och wolffska gångarna, men även ur andra embryologiska strukturer som urogenitalt sinus och primitiva könssträngar. De var dock inte överens om vilka delar som utvecklades ur vad. ${ }^{338}$ Vad som går att läsa ut av diskussionen är att dessa strukturer identifierats och att 1890-talets läkare ansåg att uterus, prostatan, sinus prostaticus, prostatans stroma och bindväv utvecklades ur någon av dessa. Det står även klart att förståelsen för embryonala strukturer nått en viss komplexitet där olika delar av de inre och yttre genitalierna ansågs ha sitt ursprung i olika strukturer. I sin artikel 1895 presenterade Ramm analogin lite annorlunda:

Hvad der ledede min tanke ind på muligheden af at kastration kunde medföre skrumpning av prostata, var naturligtvis den analogi som findes mellem uterus og prostata, eller rettere mellem uterintumores og prostatahypertrofi, et forhold som först er påpeget av Velpeau. ${ }^{339}$

336 White 1893 , s. $155,185-186$.

337 White 1895 d, s. 2.

338 Ingen av dessa strukturer anses idag vara prostatans embryologiska ursprung.

339 Ramm 1895, s. 2. 
Det var nu snarare tumörerna än själva organen som han framställde som analoga. Han hävdade dock fortfarande att det fanns de som menade att uterus och prostata hade samma embryologiska grund. ${ }^{340}$

I juli 1895 höll Ramm ett föredrag vid Nordiska kirurgiska föreningens möte på temat kastration vid prostatahypertrofi. Enligt referatet i Hygiea, författat av den svenske läkaren Anders Hansson, redogjorde Ramm för analogin mellan uterusmyom och prostatahypertrofi, och att tumörerna uppstod i samma period i livet hos män och kvinnor när deras respektive könsliv började slockna. Han tog även upp diskussionerna om prostatans embryologiska ursprung och konstaterade att åsikterna gick isär om huruvida prostatan utvecklades ur de müllerska gångarna. ${ }^{341}$

\section{Varför intresset för denna analogi?}

I Hanssons referat av Ramms föreläsning, liksom i artiklar i ämnet av Borelius och andra läkare som publicerade sig, nämns framförallt analogin med uterus eller uterusmyom - trots att både Ramm och White ägnade minst lika mycket plats åt andra argument i sina artiklar om kastrering som behandlingsmetod för prostatahypertrofi. Av någon anledning var det resonemanget om analoga kvinnliga organ, och även andra jämförelser med kvinnors kroppar och organ, som samtiden valde att lyfta fram. Argument som att män som hade kastrerats, skadat en eller båda testiklarna eller inte haft normalt utvecklade testiklar ibland utvecklade prostataatrofi, eller att man sedan länge visste att kastrering av djur medförde att prostatan atrofierade, presenteras mest som stöd till huvudargumentet - analogin. Varför fick analogin en så framträdande plats trots att nästan ingen ansåg att argumentet höll eller stämde?

340 Ramm 1895, s. 3.

341 "Nordiska kirurgiska föreningens andra möte i Christiania den 11-13 juli 1895" Refererat av Anders Hansson, Hygiea, band 57, del 2, augusti, 1895, s. 171 - 172. 
Dels hängde det troligtvis samman med det White skrev i en av sina artiklar, att man ville förstå prostatatumörerna bättre genom att jämföra dem med en typ av tumörer som det fanns mer kunskap om. ${ }^{342}$ Dels med att det var lättare att överföra en behandling från ett etablerat medicinskt område, gynekologin, till ett annat medicinskt område, den begynnande urologin, än att försöka introducera kastrering som behandlingsmetod endast baserat på att det tycktes finnas en koppling mellan testiklarna och prostatan. Det analogin med uterus eller uterusmyom gjorde, som de andra argumenten inte gjorde, var att etablera en föreställning om att det fanns en koppling mellan könskörtlarna hos människor och andra organ, och att denna koppling kunde leda till tumörer. Ett avlägsnande av könskörtlarna skulle därför kunna påverka tumörerna.

I slutet av 1800-talet var medicinen ännu experimentell till sin natur. Att kunna visa att något fungerade var viktigare än att kunna underbygga behandlingar eller medicinska praktiker teoretiskt. Antiseptiken fördes fram på samma sätt: resultat var viktigare än teoretiska förklaringar. ${ }^{343}$ Det torde framgå, skrev Borelius,

att det resonemang, som ledt Ramm och White, icke är hållbart. Men det har händt förr inom vår vetenskap, att en teoretiskt origtig eller ohållbar förutsättning ledt till en praktiskt lycklig terapeutisk metod. Betydelsen af kastration som terapeutisk metod är icke beroende på, om den teoretiska förutsättningen, som ledt till dess framträdande, är rigtig eller origtig, dess betydelse är beroende på, hvilken praktisk nytta den gör de sjuke, hvilka biverkningar den har o. s. v. Men detta är frågor, som endast kunna lösas på klinisk väg. ${ }^{344}$

342 White 1895, s. 12.

343 Chapman 2016, s. 417.

344 Borelius 1897a, s. 287. 
White uttryckte sig nästan likadant: "The importance of the conclusion lies in its effect upon the prognosis and treatment." ${ }^{345}$ Det anmärkningsvärda är att både Ramm och White ändå ägnade många sidor åt att försöka föra fram analogin mellan uterus och prostata och uterusmyom och prostatahypertrofi. De erkände embryologernas invändning mot att uterus och prostata skulle ha ett gemensamt embryologiskt ursprung, men lade stor vikt vid sin berättelse om hur lika dessa två organ var och hur lika de tumörtillväxter de kunde drabbas av var. White uttryckte sig så här i sin artikel 1893:

The significance of this striking series of analogies long ago suggested by Velpeau and later formulated by Sir Henry Thompson, cannot be ignored, although this view is dismissed in a few words by the most recent essayist upon this subject, Moullin, with the remark that there is no real homology between the uterine and prostatic tumors. He advances practically nothing in support of this statement, with which I cannot agree. On the contrary, after reviewing the above evidence, I believe we are warranted in provisionally accepting this theory. ${ }^{346}$

I artikeln 1895 skrev White att det kanske verkade som att han höll fast vid denna analogi med en "omotiverad uthållighet". Han ville inte förringa kritiken, men det fanns poänger med att basera en klinisk praktik på så lösa teoretiska grunder. Mansell Moullin menade enligt White att analogin kunde fungera som ett sätt att dölja okunskapen om prostatahypertrofi, och var därför kritisk mot den. White menade dock att det viktiga var om behandlingsmetoden faktiskt fungerade, det var bättre med en analogi som resulterade i en möjlig behandlingsmetod än ingen alls. ${ }^{347}$

345 White 1893, s. 157.

346 Ibid.

${ }^{347}$ White 1895 d, s. $6,12-13$. 
Denna arbetshypotes erbjöd en möjlighet att föreslå en behandling för prostatahypertrofi. Om man istället slöt sig till Guyons eller den franska skolans teori att prostatahypertrofi var sekundär till arterioskleros så fanns det ingen anledning att ens försöka behandla den. En lokal operation eller behandling kunde inte lösa ett problem som i så fall hade att göra med kärlförändringar i hela kroppen. Hypotesen att prostatahypertrofi var ett lokalt problem, om än med okänt ursprung, såg White som en mycket mer lovande väg. Då skulle behandlingar som sattes in tidigt och omdömesgillt kunna ge ett mycket bättre resultat. ${ }^{348}$

Ramm i sin tur påpekade 1895 att analogin mellan uterusmyom och prostatahypertrofi i alla fall hade visat sig utmynna i en behandling som tycktes fungera, till skillnad från de försök som gjorts att förklara grunden till prostatahypertrofi vilka endast lett till "ofruktbara hypoteser". Han menade att resultaten av kastrering för prostatahypertrofi visat att det ledde till en förändring i tillförseln av näring till prostatan och en förändring i prostatans funktion. Andra behandlingar gav endast kortsiktiga resultat men kastrering tycktes angripa grundproblemet. ${ }^{349}$

Här gjorde alltså läkare och kirurger nya agentiella snitt: man identifierade ett kunskapsobjekt, tumören i prostatan, och jämförde det med tumören i uterus. I nästa steg försökte White placera dessa tumörer i samma kategori av tumörer så som Velpeau gjort, trots att ett agentiellt snittet gjorts vilket identifierade adenom som en tumör som uppstod i körtelvävnad och myom som en tumör som uppstår i muskelvävnad. Den kritik som embryologer och andra läkare riktat mot analogin var att organen inte vara analoga. Men White menade att det fanns så lite kunskap om de godartade tumörer som uppstod i prostatan att det var en fördel att koppla dem till uterusmyom, som man visste mer om, för att komma längre i jakten på

348 White 1893, s. 157.

349 Ramm 1895, s 7. 
en effektiv behandling. White och Ramm letade efter alla argument de kunde komma på för att argumentera för kastrering som behandlingsmetod. Genom att framhäva likheterna mellan tumörer i prostata och i uterus kunde White hävda att prostatan var en del av det genitala systemet, vilket stärkte hypotesen att kastrering skulle kunna fungera som behandlingsmetod. ${ }^{350}$

Tidens läkare gjorde många försök att dela in det urogenitala systemets körtlar och organ i de som tillhörde urinorganen och de som tillhörde genitalorganen. I diskussionen om vilket system prostatan tillhörde gjordes ytterligare ett agentiellt snitt. Även om prostatan helt klart hade ett samband med urinering och med organ som tydligt räknades till det urologiska systemet, som blåsan, så ville allt fler placera in den i genitalapparaten och dessutom kategorisera den som en körtel. Det framgår av diskussionen hur svårplacerad prostatan var. Huvudsaken för dem som förespråkade kastrering som en behandling vid prostatahypertrofi var att kunna påvisa en koppling mellan testiklarna och prostatan, även om det var ytterst oklart hur denna koppling såg ut eller exakt vad den innebar. De resultat som observerats vid kastrering av kvinnor var att myomen, och ibland hela livmodern, atrofierade. Om dessa strukturer motsvarade prostatan och dess tumörer så borde samma resultat kunna observeras hos män. ${ }^{351}$

\section{Analogins värde}

I sin artikel 1897 kritiserade Borelius analogin mellan uterus och prostatan på följande sätt:

Hvad då först beträffar den förmenta analogien från utvecklingssynpunkt mellan uterus och prostata, så torde dermed förhålla sig på följande sätt. Hos qvinnan

350 White 1893, s. 186.

351 White 1893, s. 181 - 182; White 1895d, s. 8 - 9; Ramm 1895, s. 3. 
finnes en motsvarighet till prostata. Redan 1672 har de Graaf beskrifvit några körtlar kring uretra, som han betecknat såsom kvinnans prostata. Leuckhart har framhållit det samma och Virchow har i 5:e bandet af sitt arkiv beskrifvit såsom en af honom ofta gjord iakttagelse, att hos äldre kvinnor träffas vanliga prostatakonkrement i dessa körtlar. I ett modernt arbete har Aschoff (Virchows Archiv B. 138) genom sina undersökningar kommit till det resultat, att de körtlar, som finnas kring den kvinnliga uretrans nedre och yttre hälft, och som utmynna i uretra nära orificium eller i vestibulum, motsvara mannens prostata [...] Allt syntes mig tala för, att vi i dessa körtlar hafva den embryologiska motsvarigheten till prostata och att sålunda denna ingalunda är uterus. ${ }^{352}$

Borelius konstaterade att den kvinnliga prostatan hade hittats redan 1672: Skenes körtlar, en grupp körtlar kring urinrörets mynning hos kvinnor. Han hade en annorlunda förklaring till hur idén om en analogi mellan prostatan och uterus kan ha uppstått. Han menar att analogin uppstått eftersom en struktur i prostatan, prostatic vesicle, hade fått namnet uterus masculinus. Den var enligt Borelius otvivelaktigt en embryonal rest och borde snarare kallas vagina masculina. ${ }^{353}$

Det fanns ytterligare bevis för att uterus och prostatan inte kunde ha ett gemensamt embryologiskt ursprung, menade Borelius. Redan 1882 hade Launois vid sina studier av prostatan på Hôpital des Enfants i Paris obducerat en tioårig pojke som avlidit där. Fallet illustrerade så tydligt att analogin inte kunde stämma att Borelius infogade en tecknad bild.

352 Borelius 1897a, s. 285.

353 Ibid. 


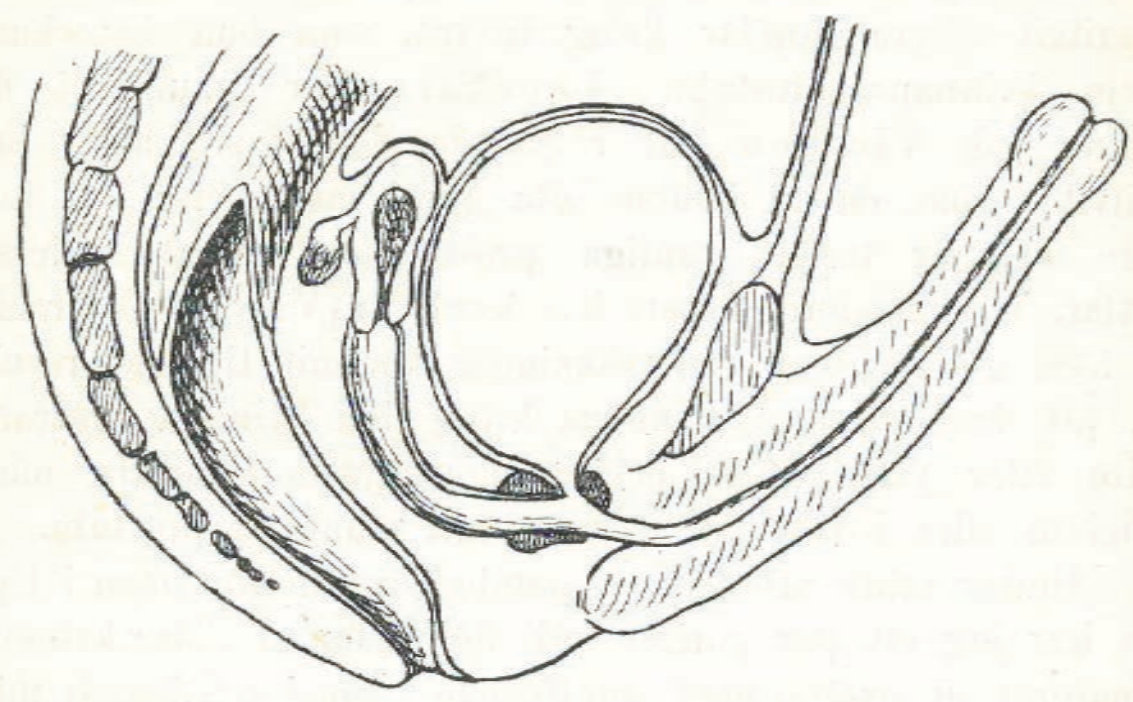

Fig. 14 .

Källa: Jaques Borelius, "Bidrag till den s. k. prostatahypertrofiens patologi och terapi”, Hygiea, Del 1, band 59, del 1, februari, 1897, s. 286.

Hos denna pojke fanns både en uterus och en prostata. Borelius drog slutsatsen att uterus masculinus därför inte kunde betraktas som en motsvarighet till den kvinnliga uterus, och inte heller kunde uterus vara en motsvarighet till prostatan, eftersom pojken hade utvecklat såväl en prostata som en uterus. ${ }^{354}$

Kritik mot analogin framfördes även av flera av andra läkare och kirurger som deltog i diskussionen om kastrering som behandlingsmetod. Bland dem var Mansell Moullin en av de starkaste rösterna och en av dem som publicerade flest artiklar i ämnet. Han ställde sig bakom hypotesen att prostatahypertrofi berodde på en tumörtillväxt i prostatan, men påpekade att dessa tumörer och tumörerna i uterus inte bestod av samma vävnad: tumörerna i uterus bestod av muskelvävnad och de i prostatan av körtelvävnad. Mansell Moullin menade också att uterus utvecklades ur de müllerska gångarna och prostatan ur de wolffska. ${ }^{355}$ Den sanna

354 Borelius 1897a, s. 286.

355 Se bland annat Mansell Moullin 1893a, s. 655. Även refererad i White 1893, s. 157. 
homologin fanns enligt Mansell Moullin mellan uterus och prostatic utricle (även kallad uterus masculinus). Att denna struktur fanns i prostatan berodde enligt Mansell Moullin på hur prostatan vuxit fram, och den hade inte heller något att göra med tumörtillväxt eller hypertrofi. ${ }^{356}$

Borelius menade att de Graaf och andra efter honom hade identifierat den verkliga analoga strukturen hos kvinnor, Skenes körtlar, men Mansell Moullin menade att om det fanns en struktur hos kvinnan som motsvarade den manliga prostatan så fanns den inte i närheten av uterus, utan i vävnaden i perineum, alltså mellangården. ${ }^{357}$ Det är förvisso i närheten av Skenes körtlar, men Mansell Moullin identifierade inte Skenes körtlar som den kvinnliga motsvarigheten till den manliga prostatan.

Både prostatan och uterus innehöll glatt muskulatur, men både mängden och funktionen skilde sig åt helt, påpekade Mansell Moullin. De svulster som kunde drabba uterus och prostatan var förvisso lika varandra så till vida att de var runda till formen. De var även anatomiskt lika: de kunde ha formen av polyper eller vara inkapslade, men liknande svulster kunde uppstå i även andra organ. 358

Den finske professorn i kirurgi Maximus Widekind af Schultén (1847-1899) menade att de undersökningar som hade gjorts på både människor och djur hade visat att den anatomiska likhet och analogi mellan uterus och prostata som Ramm talade om inte fanns. Enligt honom fanns det därför inte heller någon teoretisk grund för att kastrering skulle fungera för att behandla prostatahypertrofi. ${ }^{359}$

Den likhet eller analogi mellan uterusmyom och prostatahypertrofi som Velpeau pekat på, och som hade vidareutvecklats av Thompson, Virchow och nu till slut White och Ramm, var en svag grund att bygga på. Den vetenskapliga berättelse som White och Ramm försökte berätta om en gemensam embryologisk

\footnotetext{
356 Mansell Moullin 1894b, s. 908.

357 Ibid.

358 Ibid.

359 ”Nordiska kirurgiska föreningens tredje möte...” 1897, s. 390.
} 
grund, en likhet i vävnader och en likhet mellan de två tumörsorterna, vacklade redan från början. Borelius, Mansell Moullin och till viss del White och Ramm själva hade invändningar mot berättelsen, men det betydde inte att de avfärdade eller motsatte sig kastrering som behandling mot prostatahypertrofi. Snarare framhöll både White och Borelius att det inte var så nödvändigt att teoretiskt förstå en behandlingsmetod, om den kliniskt hade visat sig ha god effekt. Den medicinska diskursen satte klinisk erfarenhet framför teoretisk underbyggnad.

Sökandet efter teoretiska förklaringar till att kastrering skulle vara en fungerande behandling mot prostatahypertrofi fortsatte. White och Ramm, som inte var ensamma om sin tro på denna behandling men var de första som provade metoden och publicerade resultaten, tycks ha använt analogin hämtad från Velpeau mest som en språngbräda in i en annan diskussion. Båda författarna utgår från Velpeau i sina längre artiklar i ämnet. ${ }^{360}$ Analogin hämtad från äldre auktoriteter på området öppnade upp för att överhuvudtaget diskutera kastrering av män, ett ingrepp som inte var helt oproblematiskt att föreslå.

En viktig del av debatten om kastrering som behandlingsmetod handlade om hur olika läkare såg olika strukturer i kroppen och därav drog olika slutsatser om vad prostatahypertrofi var för något. När Borelius makroskopiskt och mikroskopiskt studerade de lobuli som Velpeau och Thompson hade noterat i prostatan kunde han inte se dessa som verkliga tumörer. Istället ansåg han att de tycktes vara vävnadsförändringar som kom med åldern oavsett om prostatan var förstorad eller inte. ${ }^{361}$

Innan konsensus uppstår i en fråga, eller när nya observationer leder till att vedertagen kunskap ifrågasätts, uppstår situationer som denna inom vetenskapen. Mikroskopet kunde leda olika betraktare till olika slutsatser: i intra-aktion mellan läkare, mikroskop och prostatan skapades olika kunskaper om prostatan och

360 Ramm 1895; Ramm 1896; White 1893; White 1895d.

361 Borelius 1897a, s. $266-267$. 
prostatahypertrofi. Men denna intra-aktion var beroende av mikroskopets existens. Det är ett tydligt exempel på den materiellt-semiotiska praktik som Haraway menar skapar objektet, i detta fall tumören/icke-tumören, och subjektet, läkaren som ser och blir övertygad om det ena eller det andra, och där en viktig del är den teknik som finns att tillgå, i detta fall mikroskopet.

Enligt Barads teori sker en intra-aktion mellan läkare, mikroskop och vävnad. Vilka slutsatser som drogs om dessa strukturer påverkades lika mycket av läkarens förkunskaper och praktiker som av apparaten (mikroskopet), som gjorde vissa strukturer synliga på vissa sätt. Därtill kunde de fysiska strukturerna bara framträda på vissa sätt under de förutsättningar som rådde, och de fysiska objekten begränsade i sin tur de möjliga tolkningarna på grund av sin obevekliga materialitet. Intra-aktionen kunde dock leda till flera tolkningar som uppfyllde tidens vetenskapliga krav på godtagbar kunskap. De agentiella snitten som avskilde lobuli i prostatan från den omkringliggande vävnaden och strukturerna gjordes lika av alla läkare i materialet, alltså deras anatomiska strukturer var fastställda. Men vad dessa lobuli var eller hade för funktion fanns det fortfarande olika uppfattningar om.

Det blir också tydligt hur situerad denna kunskap var i sin samtid. Likheterna mellan uterusmyom och prostatahypertrofi hade observerats tidigare, kastrering av kvinnor hade redan utförts under en period och kopplingen mellan ovarier och uterus och prostatan och testiklarna hade gjorts. Det som hände i början av 1890talet var att det tycktes uppstå en kritisk massa av information och teknik som gjorde att White och Ramm, oberoende av varandra, drog samma slutsatser om kastreringens potential som behandlingsmetod för prostatahypertrofi, och dessutom kunde presentera dem för sina läkarkollegor - varav flera betraktade slutsatsen som ganska självklar mot bakgrund av tidens kunskapsläge. ${ }^{362}$ Vissa blev

362 Se till exempel Mansell Moullin 1893a, s. 655; Mansell Moullin 1893b, s. 765; Griffiths 1893, s, 765. 
intresserade av denna möjlighet, andra förhöll sig skeptiska, men ingenstans i den debatt som jag har följt fanns dömdes idén ut som helt orimlig.

Istället utbröt något av ett bråk om vem som egentligen hade tänkt tanken först. William White beklagade sig i The British Medical fournals avdelning "Correspondence" att Mansell Moullin tre gånger hade påpekat att han föreslagit ingreppet för en patient redan i november 1892, före både White och Ramm. White kontrade med att han hade berättat om sin uppfattning i frågan för en $\mathrm{dr}$ John S. Billings redan sommaren 1892. ${ }^{363}$

En av de största anledningarna till att kastrering som behandlingsmetod mottogs positivt av så många läkare och prövades på så många patienter var att den presenterades vid just denna tid, när just dessa förutsättningar förelåg för att förstå metodens potential. Kunskaper om den manliga och den kvinnliga kroppen kunde mötas och i detta möte kunde en behandling överföras från gynekologin till den begynnande urologin och accepteras av läkarkåren.

\section{Ovarier och testiklar}

I diskussionen kring möjliga analoga organ spelade könskörtlarna, alltså ovarier och testiklar, en viktig roll. Samband mellan ovarierna och livmodern och mellan testiklarna och prostatan hade konstaterats tidigare av Rudolf Virchow och Alfred Hegar (1830-1914). Att manlig kastrering gjorde att prostatan inte utvecklades, om den gjordes pre-pubertalt, eller atrofierade, om den gjordes post-pubertalt, hade varit känt länge. Det var mycket som fortfarande var oklart när det gällde dessa körtlars funktion och roll, men de ansågs ha stor betydelse både för fostrets utveckling och senare i livet. Kopplingen till den reproduktiva funktionen var delvis klarlagd enligt läkarna, det var snarare den andra påverkan som dessa körtlar verkade ha på kroppen som var oklar. I denna fråga hade Borelius inte så mycket att säga. Han konstaterade helt enkelt att "man om förhållandet mellan

363 White 1895a, s. 50. 
testes och prostata egentligen ej känner mera än att testes hafva en inverkan på prostata, ej huru denna inverkan sker eller på hvilken väg den ledes”. ${ }^{364}$ Därför lämnar vi nu Borelius en stund för att se hur de internationella läkare som uttalade sig i debatten såg på sambandet mellan uterus och ovarierna, prostatan och testiklarna.

Rent teoretiskt hade man kunnat förutse äggceller redan på 1600-talet, och i slutet av 1600-talet hade man för första gången kunnat se spermier i mikroskop. Ägg hos däggdjur kunde bekräftas i början av 1800-talet genom mikroskopiska studier och 1895 observerades och avtecknades hos möss sammansmältningen av ägg- och spermieceller. ${ }^{365}$ Men förutom att bilda könsceller (äggceller och spermier) var det oklart vad ovarier och testiklar egentligen gjorde. Man visste lika lite om förhållandet mellan testiklar och prostata hos män som om det analoga förhållandet mellan ovarierna och uterus hos kvinnor, men att det fanns ett samband var obestritt. ${ }^{366}$

I debatten om kastrering och om likheter och olikheter mellan kvinnor och mäns kroppar började man tala om könskörtlarnas "tvåfaldiga påverkan" på kroppen. Återigen fick kvinnokroppen, den kropp man ansåg sig veta mer om, fungera som modell för att förstå den manliga kroppen. Utifrån observationer av kvinnokroppen och ovariernas påverkan på uterus började flera läkare undra om motsvarande inte skulle kunna gälla män och testiklarnas påverkan på prostatan.

Den tvåfaldiga påverkan vi idag tillskriver testiklar och ovarier är en reproduktiv funktion och en endokrin, men vid denna tid var den tvåfaldiga påverkan en "normal" och en "sjuklig" eller "abnorm" påverkan på kroppen. Den sjukliga påverkan hos kvinnor bestod i att ovarierna ansågs orsaka uterusmyom när deras funktion degenererade, vilket kunde korrigeras genom att ovarierna

\footnotetext{
364 Borelius 1896, s. 431.

365 Dean Clift \& Melina Schuh, "Restarting life: fertilization and the transition from meiosis to mitosis", Nature Reviewes Molecular Cell Biology, vol. 14, 2013, s. 549 - 562.

366 Ramm 1896, s. 31.
} 
avlägsnades. Detsamma skulle kunna gälla män, att testiklarna påverkade prostatan och att det ledde till förstoring när deras funktion degenererade. ${ }^{367}$

Den hypotes som under slutet av 1800-talet började träda fram som den främsta utmanaren till tanken att kroppen styrdes av nervpåverkan var teorin om "inre sekretion". Dessa två teorier var dock inte ömsesidigt uteslutande, utan det fanns läkare som spekulerade kring en inre utsöndrad substans som genom nerverna påverkade kroppen. Den framstående endokrinologen Edward Schäfer (1850-1935) menade så sent som 1895 att det utan tvekan var så att körtlarna utövade sitt inflytande över kroppen genom nervsystemet. ${ }^{368}$

Den franske fysiologen Claude Bernard (1813-1878) hade introducerat teorin om inre sekretion redan 1855, även om han använde termen på ett annat sätt än man gjort senare inom medicinen. Han hade identifierat två utsöndringsfunktioner hos levern: en yttre utsöndring av galla och en inre utsöndring av glukos i blodet. Bernard undersökte även endokrina körtlar, som sköldkörteln och binjurarna. ${ }^{369}$ Intresset för Bernards och andras forskning om endokrina körtlar och inre sekretion återkom i slutet av århundradet med bland annat organterapin. ${ }^{370} 1905$ gav den brittiske fysiologen Ernest Starling de ämnen som utsöndrades av de endokrina körtlarna namnet hormoner. ${ }^{371}$

När läkare och kirurger i slutet av 1800-talet diskuterade testiklarnas möjliga påverkan på kroppen, främst prostatan, var de praktiska erfarenheterna från gynekologin och de teoretiska spekulationerna om nerver och inre sekretion vägledande. Det var dock oklart på vilket sätt testiklarna påverkade organismen -

367 Ramm 1896, s. 31.

368 Sengoopta 2006, s. $11-12$.

369 Viktor Cornelius Medvei, The history of clinical endocrinology: a comprehensive account of endocrinology from earliest times to the present day, Parthenon Pub. Group, Carnforth, Lancs., UK, 1993, s. 123.

370 Sengoopta 2006, s. $11-12$.

371 Ibid, s. 1. 
genom en reflexverkan i nervsystemet eller genom en till stor del okänd utsöndring av inre sekretion transporterad av blodet? ${ }^{372}$ Allt fler började dock anse att testiklarna inte bara producerade spermier utan att de hade en mer allmän påverkan på kroppen. Av dessa två funktioner ansågs dock spermieproduktionen vara den som tog mest energi i anspråk, eftersom den var mer specialiserad. ${ }^{373}$

Ovarier och testiklar hade alltså förutom en "normal" och "abnorm" påverkan på kroppen även en reproduktiv funktion (att producera äggceller respektive spermier), samt en mer allmän påverkan på kroppen under dess utveckling från barn till vuxen. Vissa läkare hävdade att ovarier och testiklar hade precis lika stor inverkan på den kvinnliga respektive den manliga kroppen. ${ }^{374}$

White hade börjat spekulera kring testiklarnas påverkan på de övriga körtlarna i det sexuella systemet - prostatan, Cowpers körtlar och sädesblåsorna - och undrade om inte en åldersbetingad förändring i testiklarna skulle kunna vara orsaken till prostatahypertrofi. ${ }^{375}$ Denna tanke föregicks av ett resonemang som flera läkare gav uttryck för under debatten: att ovarier och testiklar primärt hade ett essentiellt syfte, nämligen att se till att kroppen utvecklades från barn till vuxen. Deras sekundära funktion var att producera könsceller, och den fortgick efter att den första funktionen avtagit när kroppen nått sin vuxna form. I detta skede, när ovarier och testiklar slutat att producera vad det nu var som gjorde kvinnor till kvinnor och män till män och endast producerade könsceller, menade White att "the testicle and the prostate would thus at this time have a closer physiological resemblance to the ovaries and uterus that at any other period of life". 376

\footnotetext{
372 Ramm 1896, s. 31.

373 Ramm 1896, s. 31; White 1895d, s. 2 - 3.

374 White 1895d, s. 2 - 3; Mansell Moullin, 1894b, s. 909

375 White 1895d, s. 2.

376 Ibid, s. 4.
} 
White med flera tänkte sig alltså att det var produktionen av könsceller som utövade en tydlig påverkan på de övriga sexuella organen efter puberteten. När kroppen var färdigutvecklad behövdes inte den form av återhållande kraft han tänkte sig fanns under puberteten, och frånvaron av denna kraft kunde förklara förekomsten av abnorma svulster i uterus och prostata senare i livet. Om testiklarna producerade ett ämne som dels påverkade kroppens utveckling och tillväxt, dels styrde bildandet av könsceller, så den första funktionen inte längre behövdes när kroppen var fullt utvecklad. Och om någon form av vital energi som behövdes för den första funktionen dock inte upphörde, då skulle denna kunna orsaka onormal förstoring av normala strukturer, resonerade White. ${ }^{377}$ Han menade att det var ett kliniskt fastställt faktum att uterusmyom bildades till följd av en överproduktion av något ämne eller någon energi som inte förbrukades vid produktionen av könsceller. När ovarierna atrofierade av ålder orsakade detta ett "tillbakadragande av nervös och vaskulär tillförsel" till uterus som medförde att myom inte bildades eller växte till, eller till och med att de försvann. Nu försökte han visa att detsamma gällde testiklar och prostata. ${ }^{378}$ Han använde inte begreppet "inre sekretion" för att förklara denna påverkan, men hans resonemang ligger mycket nära den teorin.

Som Borelius påpekade i sin artikel hade man kunnat observera en påverkan mellan testiklarna och prostatan, men ingen visste hur den gick till. Det första steget för att kunna berätta en vetenskaplig berättelse om kroppen där hormonerna spelade en stor roll hade tagits. Man hade ännu inte kunnat observera att det fanns en påverkan, men visste inte hur den gick till.

377 White 1895 d, s. $4-6$

378 Ibid, s. $6-7$. 


\section{Det manliga klimakteriet}

I försöken att förklara hur påverkan mellan testiklarna och prostatan gick till dök den gamla frågan om ett manligt klimakterium upp. Både White och Ramm gjorde försök att hitta en motsvarighet till den kvinnliga menopausen hos män. Ramm drog en parallell mellan uterusmyon och prostatahypertrofi: "Det er en kjendt Sag, at Uterusmyomerne ikke dannes (som Regel), efterat Menopausen er indtraadt. Hos Manden kommer der ingen Prostatahypertrofi, hvis den ikke har indfundet sig før det 70de Aar."379 Vidare ansåg han att kastrering eller menopausen hos kvinnor kunde hindra att myom uppstod eller att de tillbakabildades. ${ }^{380}$ Han frågade sig varför detsamma inte gällde män när de kom i den "klimakteriske (!) Periode". ${ }^{381}$ Enligt Ramm kunde det vara så att det inte fanns någon sådan period i livet för män. Det var otvivelaktigt så att perioden när reproduktion var möjlig var mycket längre för män än för kvinnor, han hade själv hittat levande spermier hos män över 70 år som var sexuellt aktiva. Därför var det kanske så att män behövde uppnå en ännu högre ålder för att den naturliga atrofieringen av prostatan och prostatahypertrofi skulle uppstå. ${ }^{382}$

När Ramm fick motta kritik för analogin mellan uterusmyom och prostatahypertrofi, eftersom det påpekades att dessa tumörer uppstod vid helt olika ålder hos kvinnor och män, lyfte han återigen fram argumenten kring mäns och kvinnors könsliv. Han upprepade vad han tidigare hävdat, att kvinnor drabbades av uterusmyom i 30-40-årsåldern, alltså under den reproduktiva perioden i livet, och sedan slutade myomen växa eller försvann i och med menopausen. Och det var precis likadant med prostatahypertrofi hos män: den uppträdde som tidigast i 55-årsåldern, under mäns reproduktiva period. Att

\footnotetext{
${ }^{379}$ Ramm 1896, s. 29.

380 Ibid.

${ }^{381}$ Ibid.

382 Ibid, s. 30.
} 
prostatahypertrofi uppstod för första gången hos män efter 70 års ålder var dock ovanligt. 383

Även White menade att det kunde finnas ett manligt klimakterium. Han hänvisade till Thompsons uttalande om analogin mellan uterusmyom och prostatahypertrofi:

\begin{abstract}
"these disturbances occur at about the same time in the sexual life of the two sexes, that is, during the latter half of the reproductive period. This ends sooner in the female than in the male, and accordingly we find the growths appearing in the former at a somewhat earlier age". 384
\end{abstract}

White beklagade att många av hans prostatapatienter dog för tidigt för att han skulle kunna visa att en naturlig atrofiering av testiklarna förhindrade att prostatahypertrofi uppstod eller minskade av sig själv. Vid avlägsnandet av testiklar hade White kunnat konstatera att förekomsten av spermier inte verkade påverka utvecklingen av prostatahypertrofi. Prostatahypertrofi kunde uppstå även om det inte fanns några levande spermier i patientens testiklar. ${ }^{385}$

Observationer hade visat att prostator hos män som var över 80 år generellt sett var mindre än hos män i sextioårsåldern, men eftersom det var svårt att veta exakt hur länge mannens reproduktiva liv varade så var det svårt att med någon vidare tyngd hävda att detta motsvarande atrofieringen av uterusmyom hos kvinnor. Men undersökningar på området började allt mer tyda på att prostatahypertrofi uppstod tidigare i medelåldern än vad man trott. Statistiken över prostatahypertrofi baserades på vad läkare rapporterade när patienterna väl sökte vård för allvarligare problem, och förstoringen hade då kunnat utvecklas

383 Ramm 1895, s. $2-3$.

384 White 1893, s. 156.

385 White 1895 d, s. $7-8$. 
under många år. ${ }^{386}$ Alltså uppstod prostatahypertrofi kanske ännu tidigare, under mannens reproduktiva period.

När White hade diskuterat kritiken mot ett manligt klimakterium vred han sitt resonemang ett varv till. Att påverkan på prostatan kunde vara lika stor även efter att testiklarna hade slutat producera spermier kunde tyda på att det okända ämne som White tänkte sig att testiklarna producerade och som kanske hade med spermieproduktionen att göra (och som White inte kunde förklara men ändå ansåg sig kunna observera), fortsatte att produceras efter att spermieproduktionen hade upphört. När spermieproduktionen upphört löpte ämnet amok och orsakade prostatahypertrofi. Detsamma skulle kunna gälla ovarier och uterusmyom i de fall där uterusmyom uppstod efter menopausen eller inte försvann i och med denna. ${ }^{387}$

Ett känt fenomen i den kvinnliga kroppen, menopausen, användes alltså som en förklaringsmodell för hur det skulle kunna fungera i den manliga kroppen. Både Ramm och White tyckte sig se bevis för att det manliga könslivet styrdes av någon inverkan från testiklarna, precis som ovarierna styrde det kvinnliga. Genom att diskutera när den reproduktiva perioden faktiskt tog slut för män gick det att göra en kvalificerad gissning att om män bara fick leva länge nog så skulle även de inträda i ett stadium som liknade menopausen. Följden av det skulle bli en naturlig atrofiering av prostatan. Denna argumentation var egentligen inte ämnad att bevisa att det fanns ett manligt klimakterium hos män, utan att ge stöd för tesen att ett avlägsnande av testiklarna kunde skynda på denna naturliga processen som kunde få prostatahypertrofi att tillbakabildas. Grunden för argumentationen vilade på antagandet om ett liknande förhållande och en liknande påverkan mellan testiklar och prostata som mellan ovarier och uterus.

386 White 1895 d, s. 7.

387 Ibid, s. 8. 


\section{Kvinnokroppen som kunskapskälla}

Ovariers och testiklars påverkan på kroppen och deras funktion var en viktig del av diskussionen om kastrering. Den reproduktiva funktionen sågs som klarlagd och fastställd, men det fanns olika hypoteser om könskörtlarnas övriga påverkan. De flesta läkare var överens om att de hade stor betydelse för fostrets utveckling och utvecklingen från barn till vuxen.

Det spekulerades en hel del om en "tvåfaldig" funktion hos dessa könskörtlar som man tyckte sig kunna observera. Dels handlade det om den reproduktiva funktionen och dels den påverkan som fick barn att under puberteten utvecklas till vuxna. Men sen fanns det även en annan, till största delen okänd funktion, som skulle kunna ge två olika utfall. Antingen att den funktion som styrde utvecklingen av kroppen under puberteten skulle kunna gå från "normal" till "abnorm", eller att funktionen som producerade könsceller skulle kunna gå från "normal" till "abnorm" och då orsaka myom eller prostataförstoring. Det viktiga i debatten var att kunna visa på en påverkan av testiklarna på prostatan som kunde bli negativ och därför rättfärdiga kastrering som behandlingsmetod.

Under 1890-talet användes flera etablerade medicinska kunskaper om kvinnan som modell för den manliga kroppen. Gynekologins etablering under mitten av 1800-talet och den kunskap som producerades där om kvinnokroppen kunde potentiellt överföras från ett medicinskt specialistområde till ett annat. Argumentationen för och emot kastrering tog sin början i en uppfattad analogi mellan organ i den kvinnliga och den manliga kroppen. I första hand var det uterus och ovarierna som sågs som analoga med prostatan och testiklarna, så att kunskap om de förra kunde tillämpas på de senare. I förlängningen fick en sjukdom som uteslutande drabbar personer som har en livmoder, uterusmyom, fungera som en modell för en sjukdom som endast drabbar personer som har en manlig prostata, prostatahypertrofi. Kvinnokroppen fick också fungera som modell för hur den reproduktiva perioden i livet påverkade dessa sjukdomar, och 
läkare sökte efter en manlig motsvarighet till den kvinnliga menopausen som skulle kunna förklara varför prostatahypertrofi inte uppstod efter den perioden i livet.

Läkare och kirurger ägnade mycket tid åt att förklara hur lika de tumörer som drabbade uterus och prostatan var och att argumentera för att en etablerad behandling för uterusmyom, kastrering, kunde överföras till män och till kastrering som behandling mot prostatahypertrofi. Den ursprungliga analogin mellan uterus och prostatan möttes av protester från embryologer och ingen sann homologi mellan organen kunde etableras. Argumentationen försköts då till en analogi mellan tumörerna. Även den delen av berättelsen mötte dock motstånd: bland andra Mansell Moullin påpekade att tumörer av denna sort även kunde drabba andra organ i kroppen.

Genom att peka på den etablerade kopplingen mellan uterus och ovarier kunde läkare och kirurger hävda en koppling mellan prostatan och testiklarna. Denna del av berättelsen var vedertagen sedan tidigare, även om ingen kunde förklara helt hur kopplingen mellan prostatan och testiklarna fungerade. Poängen med att hävda att det fanns en koppling mellan testiklarna och prostatan var effekten av att skära av den. Debatten om kastrering som behandlingsmetod för både uterusmyom och prostatahypertrofi handlade om att visa varför kopplingen mellan könskörtlarna och uterus eller prostatan kunde bli negativ och att en fungerande behandling kunde vara att skära av denna.

Att menopausen fick uterusmyom att stanna i växten, försvinna eller inte uppstå fick läkarna att spekulera om en manlig motsvarighet. Om det fanns ett manligt klimakterium stärkte det argumentet för att kastrera, eftersom en kastrering skulle skynda på denna process hos män precis som den gjorde hos kvinnor med uterusmyom. Allt kom att hänga på den kliniska erfarenheten av att kastrera män för att behandla prostatahypertrofi. Skulle tiden utvisa att det faktiskt fungerade trots att teorin bakom var svag? Eller skulle behandlingen visa sig vara verkningslös? Jämförelsen med kvinnan: uterusmyomen, kopplingen mellan ovarier och uterus och menopausen, uppbringade inga helt övertygande 
argument för kastrering som behandlingsmetod för prostatahypertrofi, men den bidrog till att upprätthålla intresset för kastrering och till och med att metoden började användas för att behandla prostatahypertrofi. 


\section{Prostatan hos avvikande män}

Hela grunden till förslaget att kastrera män för att bota deras prostatahypertrofi var en observerad såväl som föreställd koppling mellan testiklarna och prostatan. Vägen dit hade gått via kvinnokroppen och kopplingen mellan ovarier och uterus, men framförallt via den påstådda analogin mellan uterusmyom och prostatahypertrofi. Både White och Ramm hade fått hela idén till kastrering som behandlingsmetod från denna analogi. ${ }^{388}$ Analogin väckte vidare frågor om testiklarna: Hur fungerade de och vad gjorde de i den manliga kroppen? Och framförallt: På vilka sätt påverkade de prostatan?

Det här kapitlet handlar om de kategorier av män vars kroppar den "normala" mannen jämfördes med för att producera kunskap om hur testiklarna påverkande prostatan och hur detta gav stöd för kastrering som behandlingsmetod för prostatahypertrofi. Studierna av dessa kategorier öppnade också dörren till ensidig kastrering, något som diskuterades alltmer i och med att dubbelsidig kastrering fick kritik. Hur testiklarna mer i allmänhet påverkade den manliga kroppen, och effekterna av kastrering på den manliga kroppen, berör jag endast mycket kortfattat här för att återvända till ämnet i kapitel 10 .

\footnotetext{
388 “Hvad der ledede min tanke ind på muligheden af at kastration kunde medföre skrumpning af prostata, var naturligvis den analogi som findes mellem uterus og prostata, eller rettere mellem uterintumores og prostatahypertrofi, et forhold som först er påpeget af Velpeau" Ramm1895, s. 2. "It was the apparent analogy between the uterine and prostatic growths which led me to the investigation that resulted in my suggesting this operation [castration] to the profession." White 1895d, s, 8.
} 
William White och Frederik Ramm tog vägen via kvinnokroppen för att visa att det fanns en koppling mellan testiklarna och prostatan som var nästan likadan som kopplingen mellan ovarier och uterus, men det var inte någon direkt ny kunskap inom medicinen. John Hunter (1728-1793) hade redan 1792 i Observations on Certain Parts of the Animal Oeconomy visat att alla delar av det manliga reproduktionssystemet på något sätt var beroende av testiklarna.

I det här kapitlet behandlar jag två övergripande frågor: Vilken kunskap ansåg läkare under slutet av 1800-talet att avvikande män kunde bidra med när det gällde vad som ansågs vara "normala" mäns utveckling av en "normal" prostata? Och på vilket sätt påverkade dessa jämförelser framförandet av ensidig kastrering som ett alternativ till den dubbelsidiga?

\section{Att kategorisera avvikande kroppar}

Att dela in män i kategorier och jämföra dem var en stor del av processen för att förstå testiklarnas påverkan på den manliga kroppen. Att jämföra olika kroppar med varandra var överhuvudtaget en vanligt förekommande praktik inom medicinen i slutet av 1800-talet. Till exempel användes studier av hermafroditer för att klargöra den normala utvecklingen av manliga och kvinnliga kroppar. 389

De män som intresserade William White och Fredrik Ramm mest, och som Borelius kommenterade i sin artikelserie från 1897, var eunucker (män vars testiklar avlägsnats före eller efter puberteten av kulturella eller medicinska skäl); män som hade sjukliga, skadade eller ofunktionella testiklar varav vissa utvecklade eunuckism; män med kryptorkism (ingen av testiklarna hade vandrat ner i pungen), anorki (födda utan testiklar men med yttre könsorgan och en kropp som var mer manlig än kvinnlig) samt monorkism (en testikel har vandrat ner i pungen och den andra finns i ljumskkanalen eller nedre delen av buken eller saknas helt).

389 Bondestam 2010, s. 173; Fausto - Sterling 2000, s. 36. 
I det material jag har undersökt är det framförallt enskilda kroppar som avviker på olika sätt och jämförs med den "normala". Det gjordes försök att samla dessa kroppar i enhetliga kategorier. Eunucker och personer som uppvisade tecken på eunuckism var två kategorier som uppvisade mer förutsägbara kroppsliga avvikelser än de övriga - i synnerhet när det gällde prostatan - vilken hela tiden var i fokus för dessa jämförelser. Det var ofta ganska enkelt att avgöra om någon led av kryptorkism, anorki eller monorkism, men mycket svårare att dra slutsatser om vad det fick för effekter på prostatan. Den svåraste distinktionen var den mellan kryptorkism och anorki; den krävde i vissa fall en post mortemundersökning. Om en eller båda av testiklarna inte vandrade ner och inte heller gick att känna någon annanstans i kroppen så var det inte förrän vid en obduktion det säkert kunde avgöras om de saknades helt eller bara legat "gömda".

De underliggande kategorierna i läkarnas kategorisering var den binära uppdelningen i två biologiska kön: män och kvinnor. Thomas Laqueur har i Making sex. Body and gender from the Greeks to Freud hävdat att denna uppdelning inte alltid har sett likadan ut: att den har gått från en enkönsmodell, där kvinnor sågs som ofullständiga män, till en uppdelning i två motsatta kön. ${ }^{390}$ De historiker som kritiserat Laqueurs modell hävdar att beskrivningar av könskategorier och samhällets könsroller historiskt varit mer komplexa och skiftande än så. ${ }^{391}$ Anne Fausto-Sterling gör i Sexing the body. Gender politics and the construction of sexuality en historisk exposé över ämnet och visar att hermafroditer i historien av vissa, till exempel Galenos, har betraktats som ett tredje biologiskt kön. Aristoteles såg å sin sida hermafroditer som en form av tvillingar där modern inte haft tillräckligt med materia för två barn. Enligt Fausto-Sterling fäste han inte heller så stor vikt vid könsorganen utan menade att det som avgjorde manlighet och kvinnlighet var

390 Laqueur 1990.

391 Park \& Nye 1991; Stolberg 2003; Benninghaus 2012. 
"the heat of the heart". ${ }^{392}$ Vissa kulturer, som den judiska, har haft lagar för hur hermafroditer ska anpassas till samhället medan den tidiga romerska kulturen såg dem som bärare av statens förfall och därför dödade dem. ${ }^{393}$

Den västerländska kulturen har alltid på olika sätt betonat skillnader mellan kvinnor och män, men under 1800-talet konstruerades en syn på män och kvinnor som kom att uppfattas som naturlig och tidlös. Denna utveckling gjorde kategorin kön, enligt Angus McLaren, till den kategori som överskuggade alla andra när det gällde vad som avgjorde en individs personlighet. ${ }^{394}$ Vid slutet av 1800-talet var uppdelningen i två binära kön så dominerande att den tidigare kategorin hermafrodit nästan helt hade försvunnit ur medicinen. ${ }^{395}$ Eunucker samt män med anorki, kryptorkism, monorkism eller eunuckism var viktiga kategorier för skapandet av testiklarna och prostatan som kunskapsobjekt. Dessa tillstånd påverkade kroppen på olika sätt enligt läkarna, även om vissa av tillstånden inte kunde diagnostiseras förrän efter döden. Alla kategoriserades som män även om de inte alltid ansågs vara fullständiga män.

Eftersom inställningen under den period jag studerat var att alla människor var antingen män eller kvinnor, även om vissa personers tillhörighet kunde vara otydlig, så kommer jag i detta kapitel att utgå från dessa två kategorier så som de används i källorna, men ibland problematisera och nyansera bilden. ${ }^{396}$ Eunuckerna i materialet kan ses som ytterligare en kategori, men inte som en naturlig, biologisk sådan utan som en medicinskt eller kulturellt skapad. Och även om eunucken inom vissa kulturer har haft en specifik social ställning var det varken en social kategori, en könskategori eller en sexuell kategori i Europa, USA eller Sverige i slutet av 1800-talet.

\footnotetext{
392 Fausto - Sterling 2000, s. $33-34$.

393 Ibid, s. 33.

${ }^{394}$ McLaren 2007, s. 102.

395 Domurat Dreger 1998, s. 154 - 157; Bondestam 2010, s. 176.

396 Domurat Dreger 1998, s. 153; Bondestam 2010, s. $151-152$.
} 


\section{Avvikande män}

De kategorier av avvikande män som förekommer existerade redan före kastreringsdebatten, men nu började flera läkare och kirurger studera den medicinska litteraturen och utföra egna undersökningar för att ta reda på om dessa avvikelser var relevanta för debatten om kastrering som behandlingsmetod för prostatahypertrofi.

John Hunter var fortfarande en auktoritet på området. Läkaren Joseph Griffiths redogjorde 1895 i föreläsningsserien "Three Lectures upon the Testes" inför the Royal College of Surgeons in England för sina studier av testiklarna, och deras påverkan till prostatan. ${ }^{397}$ Han sammanfattade då vad som ansågs vara allmänt känt om testiklarna, som att de inte uppnådde sin fulla storlek och funktion förrän i puberteten. Det var i samband med detta som de manliga sekundära könskaraktärerna utvecklades, enligt Griffiths, och som även andra körtlar uppnådde sin fulla storlek och funktion, exempelvis prostatan. Griffiths redogjorde för testiklarnas normala storlek och vikt och hur de kändes när de var friska. Han noterade att det var vanligt att en persons testiklar, precis som många andra bilaterala organ, var olika stora, och att båda testiklarna kunde vara fullt fungerande och friska trots en markant storleksskillnad. Precis som olika individer kunde träda in i puberteten och testiklarna kunde bli färdigutvecklade vid olika

397 Griffiths 1895b, s. 791 - 794; Joseph Griffiths, "Three Lectures Upon the Testes, Lecture II", The Lancet, vol. 145, nr. 3735 (ursprungligen publicerad som volym 1, nr. 3735) mars 30, 1895c, s. 795 - 799; Joseph Griffiths, "Three Lectures Upon the Testes, Lecture III", The Lancet, vol. 145, nr. 3737(ursprungligen publicerad som volym 1, nr. 3737) april 13, 1895c, s. $916-920$. 
11. 57.

Fig. 1.

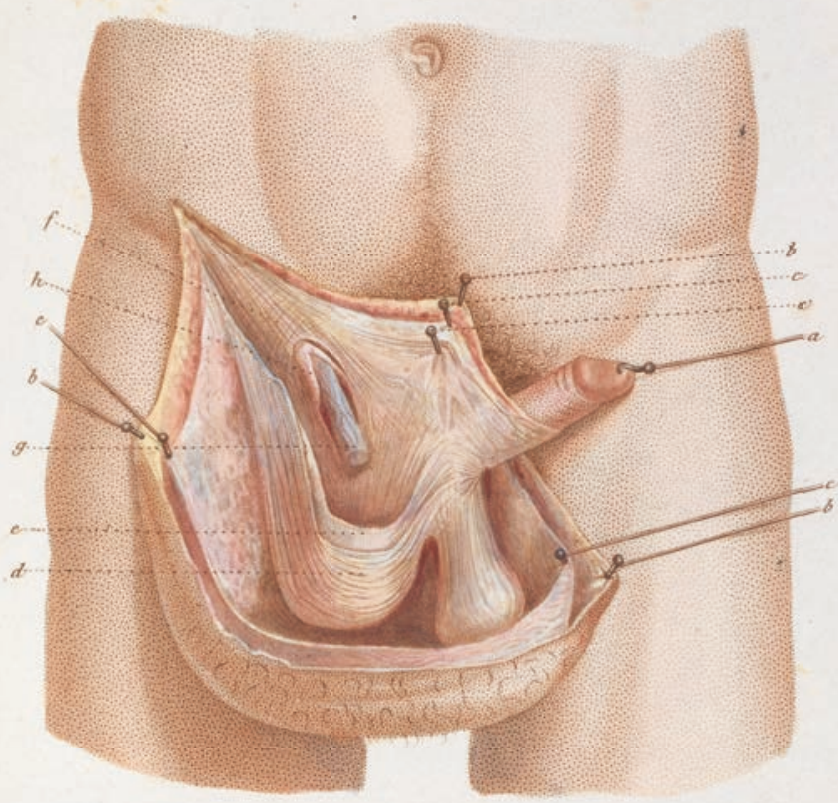

Fig. 2

Fig. 3
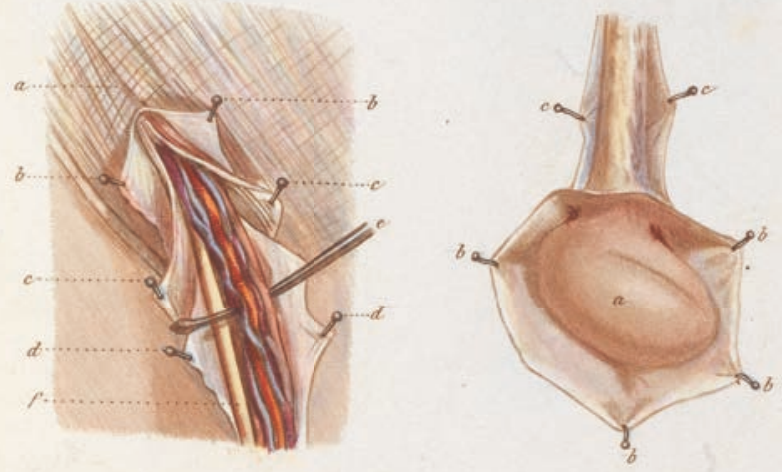
ålder, så kunde testiklarna sluta att producera spermier vid olika ålder, från 50 år till 70-80 år. ${ }^{398}$

När det gällde testiklarnas utveckling hos fostret och processen där de vandrade ner från bukhålan till pungen, det som kunde ha gått fel hos kryptorkider och monorkider, lutade sig Griffiths mot auktoriteten Hunter, som beskrivit detta i The Position of the Testes in the Foetus. ${ }^{399}$ Enligt Hunter var det inte ovanligt med avvikelser i denna process hos människor och domesticerade djur, oftast när testikeln eller testiklarna skulle passera ljumskkanalens öppning ner i pungen. Ibland missade testikeln pungen och hamnade i nedre delen av buken. ${ }^{400}$ En annan auktoritet på området, som både White och Ramm refererade till, var den franske läkaren Ernest Godard (1826-1862), som i Études sur la Monorchidie et la cryptorchidie chez l'homme 1857 hade visat att testiklarna inte utvecklades i pungen utan i buken. Testiklarna kunde vandra ner i olika stadier av fosterutvecklingen. ${ }^{401}$ Hos barn som föddes med en eller båda testiklarna kvar i buken kunde dessa vandra ner senare, men det var enligt Ramm allmänt vedertaget att om testiklarna inte hade vandrat ner före 14 års ålder så skulle de inte göra det senare heller. ${ }^{402}$

Plansch 57, Kirurgisk anatomi av ljumskkanalen. I fig.1 är det bokstaven $g$ som indikerar ljumskkanalens placering och mynning ner i pungen. Källa: Wellcome Collection. CG BY.

398 Griffiths 1895b, s. $791-793$.

399 Griffiths 1895c, s. 795. Samma process beskriver Hunter även i den första texten i Observations on Certain Parts of the Animal Oeconomy, 1792, men där under namnet "A Description of the Situation of the Testes in the Fœetus, with its Descent into the Scrotum", s. $1-20$. Det är troligtvis samma text som Griffiths avser men under ett annat namn.

${ }^{400}$ Griffiths 1895c, s. 795.

${ }^{401}$ Ernest Godard Études sur la Monorchidie et la cryptorchidie chez l'homme, Paris, 1857. Fulltext genom https://archive.org/stream/b22282543/b22282543_djvu.txt [sidan besökt 2017-10-

17] (Ingen systematisk sidhänvisning finns i dokumentet.)

${ }^{402}$ Ramm 1896, s. 38. 
Även Launois i Paris hade studerat testiklarnas förhållande till prostatan. I augusti 1894 rapporterade The Lancets korrespondent i Paris om hans studier av relationen mellan prostatan och testiklarna embryologiskt, anatomiskt och fysiologiskt. ${ }^{403}$ I oktober samma år publicerades Launois fynd i boken De l'Atrophie de la prostate, De la Castration dans l'hypertrophie de la prostate, vilken lästes av många. Borelius refererade kort Launois fynd i sin artikelserie 1897, och om förhållandet mellan testiklarna och prostatan skrev han:

Vid medfödd defekt, ofullständig utveckling, eller ektopi af testiklarne är prostata atrofisk; är bildningsfelet ensidigt, är motsvarande prostatahalva atrofisk. Om testes borttagits i yngre år (så som hos eunucker), är prostata atrofisk, likaså om testes förstörts av någon sjuklig process, blir prostata ofta atrofisk. ${ }^{404}$

Alla var dock inte överens om att det alltid var precis såhär förhållandet mellan testiklarna och prostatan såg ut. De agentiella snitt som skilde testiklarna från kringliggande strukturer hade gjorts långt före slutet av 1800-talet. Av Hunters beskrivningar av testiklar, bitestiklar, prostatan, sädesblåsorna, Cowpers körtlar och så vidare i "A Description of the Situation of the Testes in the Fœtus, with its Descent into the Scrotum" framgår att testiklarna anatomiskt hade avgränsats på samma sätt redan i slutet av 1700 -talet. ${ }^{405}$ Det som kvarstod, liksom när det gällde prostatan, var att utreda exakt vilka funktioner testiklarna hade och hur de påverkade den övriga kroppen.

403 "PARIS.", The Lancet, vol. 144, nr. 3704 (ursprungligen publicerad som volym 2, nr. 3704) aug. 25, 1894, s. 468.

${ }^{404}$ Borelius 1897a, s. 283.

405 John Hunter, Observations on Certain Parts of the Animal Oeconomy, andra upplagan, London, 1792, s. $1-20$. Fulltext genom

https://archive.org/details/observationsonce1792hunt/page/42 [sidan besökt 2019-10-17] 


\section{Eunucker}

Den kategori som togs upp och diskuterades mest i kastreringsdebatten var eunuckerna. De var en välkänd kategori och noteringar om prostatan hos eunucker var inte ovanliga. Det sågs som vedertagen kunskap att eunucker inte utvecklade någon prostata om de kastrerades före puberteten och att den atrofierade om de kastrerades senare.

Om eunucker hade det samlats kunskap i flera kulturer under lång tid. Den hade kunnat utgöra en stor källa till kunskap för 1890-talets läkare, men Griffiths var av en annan åsikt: "What is written about eunuchs is unreliable, chiefly because they as a class have always been despised by men, and whatever has been said of them has been to highly coloured by prejudice." ${ }^{406}$ Det som hade skrivits om eunucker i andra tider och kulturer rörde främst män som fătt sina testiklar avlägsnade före puberteten, oftast av kulturella skäl. Definitionen av "eunuck" i slutet av 1800-talet och början av 1900-talet var dock inte helt klar. Till exempel ansågs de män som tjänade i Förbjudna staden i Kina vara eunucker, trots att de genomgått en annorlunda kastrering som innebar att alla de yttre könsdelarna skars av, vanligtvis i vuxen ålder, alltså postpubertalt. ${ }^{407}$

Mansell Moullin menade å sin sida att observationer av eunucker hade lett till att man kände till vissa saker om prepubertal kastrering, till exempel att den påverkade prostatan. Han beskrev dock denna kunskap som "long since known and almost forgotten". ${ }^{408}$ Det förklarar delvis att William White i sin artikel om kastrering mot prostatahypertrofi 1893 skrev att han inte haft en aning om att kastrering påverkade prostatan innan han själv hade börjat genomföra djurexperiment. Först när han undersökte ämnet närmare upptäckte han att det fanns källor, som medicinska texter, där det framkom att det var välkänt att

406 Griffiths 1895b, s. 794.

${ }^{407}$ Dale 2010, s. 42.

${ }^{408}$ Mansell Moullin 1894b, s. 908; Mansell Moullin 1894c, s. 976. 
prostatan påverkades hos kastrerade hingstar och eunucker. ${ }^{409}$ I kastreringsdebatten aktualiserades denna kunskap.

När White började gå igenom litteraturen hittade han flera observationer och undersökningar av eunucker. Wenzel Gruber hade 1847 observerat en tydlig atrofiering av prostatan hos en 65-årig man som kastrerats före puberteten, Alfons Bilharz hade 1859 i sin avhandling The Anatomy of the Genital Organs of Two Ethiopian Eunuchs bekräftat Grubers fynd, och Evgenij Pelican hade 1875 publicerat Gerichtich-medizinische Untersuchungen uber das Skopzentum in Russland om en märklig sekt (skoptserna) där eunuckernas prostata inte var större än hos barn. ${ }^{410}$ Jean Giviale hade upptäckt att hos en patient som tidigare kastrerats för dubbelt bråck hade prostatan nästan helt försvunnit. ${ }^{411}$

I dessa källor blandas män som kastrerats före puberteten med män som kastrerats i vuxen ålder. Båda grupperna var intressanta för kastreringsdebatten: de som kastrerats före puberteten bidrog till kunskapsproduktionen om hur testiklarna påverkade kroppen under puberteten, och de som kastrerats efter puberteten bidrog till kunskapsproduktionen om hur ett avlägsnande av testiklarna påverkade den vuxna manliga kroppen. Den sista frågan var speciellt intressant och känslig eftersom det fanns en oro att män som kastrerades mot prostatahypertrofi skulle drabbas av feminisering eller eunuckism. I en artikel 1896 skrev Arthur Tracy Cabot (1852-1912): "we are constantly asked by patients

409 White 1893, s. 182.

410 Rysk religiös sekt där männen förväntades kastrera sig och kvinnorna skära av brösten för att uppnå syndfrihet. Grundad av Kondratij Selivanov (död 1832).

https://www-ne.se.e.bibl.liu.se/uppslagsverk/encyklopedi/1\%C3\%A5ng/skoptser

[sidan besökt 2019-10-17] Även nämnda i Griffiths 1895b, s. 793.

411 White 1893, s. 185. 
whether there is any danger of their suffering from eunuchism in any form after the castration". ${ }^{412}$

Vilka var de effekter av kastrering, framförallt före puberteten, som läkare och kirurger ville skydda sina patienter från? John Hunter hade i slutet av 1700talet gjort observationer av hur kastrering påverkade kroppen, till exempel denna: "In the perfect male the penis is large [...] On the contrary, in the castrated animal the penis is small." 413 Griffiths hade också en hel del att säga i ämnet:

If a boy when young be deprived of his testicles - castrated - the developmental changes that go on to form the characteristic features of man do not take place, and, as he is sexless, characters that are more or less intermediate between those of man and those of woman develop; indeed, such a person, commonly known as a eunuch, acquires characters that are more akin to those of the female that those of the male. ${ }^{414}$

Kvinnor som berövades sina ovarier utvecklade enligt Griffiths på motsvarande sätt "some of the characteristics of the male" ${ }^{415}$ Griffiths betecknade eunucker som "könlösa" (sexless), men eunuckism ansågs inte vara ett naturligt tillstånd och alltså inte något som kunde medföra att personens biologiska kön ifrågasattes. Eunucker var snarare personer som berövats det som skulle ha gjort dem till fullständiga män. Griffiths beskrev eunucker som:

usually large, fat and flabby, with scanty hair on the face. His pelvis is broader and his shoulders are narrower than those of the entire man; his features simulate those of the female, but are not so well cut or so delicately shaped, being, like the rest of

\footnotetext{
412 Arthur Tracy Cabot, "The question of Castration for Enlarged Prostate", Annals of Surgery, vol. 24, nr. 3. sep. 1896, s. $270-271$.

${ }^{413}$ Hunter 1792, s. $42-43$.

${ }^{414}$ Griffiths 1895b, s. 794.

415 Ibid.
} 
the frame, coarser. His voice remains like that of a boy - that is, in the high register

- though the larynx enlarges somewhat, and the vocal cords increase in length. ${ }^{416}$

Samma utveckling beskrev Griffiths hos personer som hade mycket små testiklar (eunuckoider). ${ }^{417}$ Griffiths tyckte sig se att män som kastrerades pre-pubertalt inte utvecklades normalt utan verkade "fastna" någonstans mellan kvinnor och män. Deras drag var, enligt Griffiths, mer kvinnliga än manliga, men inte tillräckligt fina eller väldefinierade för att de skulle se ut som kvinnor. Det var dessa egenskaper som Griffiths menade att eunuckoider utvecklade under puberteten.

Den mer lokala påverkan som Griffiths studerade var kopplingen mellan testiklarna och de accessoriska könskörtlarna. Han menade att genom att studera personer som fått testiklarna avlägsnade tidigt i livet kunde han se att det fanns en påverkan. Effekten av en kastrering var att de accessoriska könskörtlarna inte utvecklades fullt. Varken vävnaden eller funktionen - sekretbildning - såg ut eller fungerade som hos personer som inte kastrerats. Även de yttre genitalierna påverkades av en kastrering och enligt Griffiths hade eunucker en liten penis. Testiklarna var därför de dominerande sexuella körtlarna. ${ }^{418}$ Denna förändrade utveckling av kroppen under puberteten påverkade enligt Griffiths med största sannolikhet även psyket. ${ }^{419}$ Påverkan på psyket återkommer jag till i kapitlet om kastrering av kvinnor och män.

Även White kom till slutsatsen att prostatan hos eunucker, liksom hos kastrerade djur, "shrinks and almost disappears until only a small inelastic fibroid

416 Griffiths 1895b, s. 794.

417 Griffiths 1895b, s. 794; Griffiths anger att han själv gett detta tillstånd namnet eunuchoid från ordet eunuck, eftersom de liknade eunucker. Vad som skilde dem åt var att eunuckoider hade testiklar men de fungerade inte normalt. Griffiths 1895b, s. 794. Även omnämnt i Ramm 1896, s. 40.

418 Griffiths 1895b, s. 793.

419 Ibid, s. 794. 
mass is left". ${ }^{420}$ Han tycks avse att vuxna mäns fullt utvecklade prostata krymper efter kastrering. Samtidigt noterade han att avlägsnandet av ovarierna eller testiklarna tidigt i livet "usually changes profoundly all the characteristics physical and mental - of the individual". ${ }^{421}$

Andra läkare bekräftade Whites slutsats. Peter Johnston Freyer, som arbetade under ett antal år som läkare i Indien, hade som en del av sina officiella åtaganden fått utföra rättsmedicinska undersökningar av ett antal eunucker. Bland dem fanns både personer som hade kastrerats som barn och personer som frivilligt låtit kastrera sig som unga vuxna av religiösa skäl. Samtliga i båda grupperna hade endast en rudimentär prostata. ${ }^{422}$

Enligt Griffiths påverkade en kastrering av en vuxen man de accessoriska könskörtlarna så att strukturen hos prostatan, sädesblåsorna och Cowpers körtlar med tiden allt mer liknade den hos eunucker och eunuckoida personer. Skillnaden var att hos en fullvuxen man förändrades inte kroppen lika mycket, utan den behöll till stor del de tydliga sekundära könskaraktärerna. Han menade dock att dessa män ofta blev feta, men beskriver det som att de "get, in fact, into better condition". ${ }^{423}$

Hela diskussionen kring hur kastrering påverkade kroppen, och inte bara prostatan, var viktig för kastreringsdebatten. Att kunna konstatera att kroppen endast tycktes påverkas om kastreringen skedde prepubertalt var ovärderligt för dem som förordade kastrering av vuxna män. Det var därför viktigt att inte bara studera testiklarnas sexuella funktion utan även vilken effekt de hade på kroppen rent allmänt. Cabot refererade till Whites åsikt att testiklarna hade två funktioner: att utveckla manliga könskaraktärer under puberteten och därefter endast produktionen av könsceller. I de fall som Cabot hade hittat då män hade kastrerats

${ }^{420}$ White 1893, s. 155.

421 White 1895 d, s. 3.

${ }^{422}$ Freyer 1901b, s. 154.

${ }^{423}$ Griffiths 1895b, s. 794. 
i medelåldern eller senare hade ingen form av eunuckism eller feminisering skett. Han medgav dock att dessa personer möjligtvis i längden skulle uppvisa mindre kraft än förväntat senare i livet. ${ }^{424}$ Samtidigt rapporterade han att män efter kastrering hade drabbats av liknande vallningar som kvinnor drabbades av under menopausen, och hade fått hysteriska utbrott, men det kopplade han inte samman med feminisering eller eunuckism. ${ }^{425}$

Runt sekelskiftet 1900 kopplades eunucker och eunuckoida personers annorlunda pubertala utveckling till den första av testiklarnas två funktioner: den som ansågs vara vital för den pubertala utvecklingen. Två sekler tidigare, vid sekelskiftet 1700, hade läkare istället hävdat att det var eunuckers brist på spermieproduktion som var anledningen till att de inte utvecklade de typiska könskaraktärerna hos män. ${ }^{426}$

\section{Eunuckism och missbildade testiklar}

Läkare och kirurger som deltog i kastreringsdebatten var även intresserade av vilken påverkan medfödda missbildningar av testiklarna och av skador och sjukdomar som kunde uppstå under livet hade. Sådana fall kunde visa hur utvecklingen av prostatan, och resten av kroppen, påverkades respektive hur vuxna män påverkades om testiklarna skadades i vuxen ålder.

Bland patienterna med medfödda skador på testiklarna fanns både de som uppvisade eunuckism och de som vid första anblicken såg ut som "normala"

424 Cabot 1896, s. 271.

425 Cabot 1896, s. 274. Även Alexis Thomson hade noterat svettningar och vallningar hos en manlig patient efter kastrering liknande de som drabbade kvinnor i klimakteriet "Edinburgh Medico-Chirurgical Society”, The Lancet, vol. 155, nr. 3903 (ursprungligen publicerad som volym 1, nr. 3903) jun. 18, 1898, s. 1692.

${ }^{426}$ Michael Stolberg, "Self-pollution, moral reform and the veneral trade: Notes on the sources and historical context of Onania", Fournal of the History of sexuality, vol. 9, nr. 1 - 2, jan/april, 2000, s. $57-58$. 
vuxna män. Ramm lyfte fram en 35-årig man som vid första anblicken verkade ha fullt normala yttre genitalier. Men vid närmare undersökning hade han en mindre penis än vad Ramm bedömde som normalt för en vuxen man, och han hade två testiklar i pungen men de var inte större än mandlar. Patienten uppgav att han fick ejakulationer men enligt Ramm kunde han inte närmare beskriva denna vätska. Och vid en rektal palpering kunde Ramm inte hitta någon prostata. ${ }^{427}$ Även White beskrev ett fall med en man med underutvecklade yttre genitalier som hade en nästan oupptäckbar prostata. ${ }^{428}$

Griffiths hade i sin studie berört patienter som hade vad han ansåg vara onormalt små testiklar och därför inte hade genomgått vad som ansågs vara en normal pubertet. De diminutiva testiklarna och deras bristfälliga struktur gjorde att den normala utvecklingen uteblev på samma sätt som om testiklarna avlägsnats. Griffiths benämnde dem "eunuckoider". ${ }^{429}$

I en artikel i fournal of Anatomy and Physiology i januari 1894 redogjorde Griffiths för observationer av två eunuckoida personer. De var till utseendet på alla sätt lika eunucker, förutom att de båda hade små testiklar i pungen. Den ena personen var en patient och Griffiths konstaterade att han precis som eunucker endast hade en antydan till prostata och nästan ingen körtelvävnad. ${ }^{430}$ Den andra personen, som avlidit vid tjugo års ålder, undersökte Griffiths post mortem och noterade en fysisk likhet med en eunuck och att testiklarna var små och underutvecklade. ${ }^{431}$ Vid en post mortemundersökning var det möjligt för Griffiths att närmare studera de accessoriska könskörtlarna och det visade sig att bitestiklarna, sädesledarna, sädesblåsorna var små och prostata knappt en

${ }^{427}$ Ramm 1896, s. 39 - 40. En snarlik beskrivning finns i Ramm 1895, s. 4 men där uppges mannen vara 43 år och beskrivningen är mycket kortare.

428 White 1893, s. 185.

${ }^{429}$ Griffiths 1895b, s. 794. Även omnämnt i Ramm 1896, s. 40.

430 Griffiths 1894, s. 221.

${ }^{431}$ Ibid. 
tredjedel så stor som man kunde vänta sig hos en man i tjugoårsåldern. ${ }^{432}$ Vid närmare mikroskopiska studier noterade Griffiths noga på vilka sätt testiklarna, bitestiklarna, prostatan och sädesblåsorna skilde sig från dem hos en person med fullt fungerande testiklar. Till stor del bestod hans fynd av att konstatera att de inte utvecklats som normalt och till viss del utvecklat andra strukturer, exempelvis fanns mycket mer fibrös vävnad i prostatan än normalt och lobuli i prostatan var mycket färre till antalet. ${ }^{433}$

Vid dessa närmare undersökningar av testiklarna hade Griffiths kunnat konstatera att även om de ytligt sett liknade testiklarna hos barn så var den inre strukturen mycket annorlunda. Testiklarna hos eunuchoida personer skilde sig också från testiklar som inte vandrade ner helt och därför inte utvecklades fullt ut. Däremot liknade de testiklar som hade drabbats av en inflammation tidigt i livet eller under puberteten. Griffiths föreslog ett antal olika möjligheter till varför dessa tillstånd uppstod. Han ställde sig följande frågor: ${ }^{434}$

[1] may be asked wether it is due (1) to an inherent want of growing power in the seminal tubes, (2) to interference with the normal growth of the tubes from the result of some changes in the nerves or blood-vessels of the organ, or (3) to the destructive influence of some morbid process in the organ itself. ${ }^{435}$

Oavsett vilken orsak som låg bakom denna annorlunda utveckling av testiklarna så var det enligt Griffiths klart att detta skedde före puberteten eftersom eunuckoider liknade eunucker som kastrerats pre-pubertalt. Vid vilken tidpunkt i livet det skedde - före eller efter födseln - var oklart. ${ }^{436}$ Resultatet av denna

\footnotetext{
432 Griffiths 1894, s. 221.

433 Ibid, s. $222-223$.

434 Ibid, s. 222, $224-226$.

435 Ibid, s. $224-225$.

${ }^{436}$ Ibid, s. 225.
} 
annorlunda utveckling av testiklarna var att de inte utvecklade de sekundära könskaraktärerna under puberteten på samma sätt som "normala" män och kom därför att likna eunucker. Precis som hos eunucker utvecklades de accessoriska könskörtlarna inte fullt under puberteten, vilket gjorde att eunuckoiderna hade en liten eller nästan obefintlig prostata.

I kastreringsdebatten användes kunskapen om hur icke fullt fungerande testiklar påverkade utvecklingen av kroppen för att visa hur den vuxna manliga kroppen påverkades av en kastrering. Testiklarna behövde utvecklas fullt under puberteten för att den pubertala utvecklingen av sekundära könskaraktärer skulle ske "normalt", och en feminisering av kroppen uppstod endast om testiklarna inte fanns eller inte fungerade under puberteten. Det fanns alltså ingen risk för att en vuxen man som kastrerades som behandling mot prostatahypertrofi skulle feminiseras.

\section{Kryptorkism och anorki}

Kryptorkism innebar att båda testiklarna finns någon annanstans i kroppen än i pungen och anorki att båda testiklarna saknas helt. Läkarna och kirurgerna i kastreringsdebatten var intresserade av hur dessa tillstånd påverkade utvecklingen av prostatan, hur de påverkade utvecklingen av resten av kroppen under puberteten och hur fertiliteten påverkades.

Ernest Godard hade beskrivit monorkism, kryptorkism och anorki redan 1857 i boken Études sur la monorchidie et la cryptorchidie chez l'homme, och de hade varit kända längre än så. Godard ger en kort historisk överblick över observationer som gjorts av patienter som saknade en eller båda testiklarna från Ambroise Paré (1510-1590) och framåt. Det framgår att ämnet hade intresserat läkare och kirurger under en längre tid. ${ }^{437}$

${ }^{437}$ Godard 1857 Études sur la Monorchidie... 
Godard, liksom de läkare som debatterade om kastrering, såg monorkism och kryptorkism som problem med testikelnedvandringen. Män vars testiklar fanns i ljumskkanalen eller i andra delar av nedre buken skulle inte förväxlas med män vars testiklar atrofierat. ${ }^{438}$ Det var dock svårt att skilja dessa tillstånd åt så länge patienterna var i livet eftersom det inte alltid gick att känna var de saknade testiklarna fanns i kroppen. Anorki kunde endast diagnostiseras efter döden. Obduktioner var en viktig praktik för skapandet av kunskapsobjekt inom medicinen, och den var lika viktig för skapandet av dessa kategorier. Det var först vid obduktion eller någon annan post mortemundersökning som kroppen kunde letas igenom noggrant och testiklarnas vara eller icke-vara kunde konstateras.

\section{Påverkan på utvecklingen av prostatan}

Ramm rapporterade om en 61-årig man som vid obduktionen visade sig ha saknat testiklar sedan födseln och ha en outvecklad prostata. Dessutom var prostatan och kringliggande strukturer, en del av urinröret och blåsan, sammanväxta på ett avvikande sätt. ${ }^{439}$ Men det var få läkare och kirurger som hade visat något större intresse för prostatan när de undersökte män med kryptorkism eller andra avvikande testiklar. ${ }^{440}$ William White, Frederik Ramm och Jaques Borelius gjorde sitt bästa för att hitta de fall i litteraturen som fanns. Ramm påpekade att vid obduktion av foster hade det observerats att när testiklarna inte vandrat ner i pungen saknades ibland även sädesblåsorna, prostatan och sinus prostaticus. ${ }^{441}$ Han hade därtill hittat ett fall där en man med kryptorkism vid obduktion visat sig sakna både prostata och sädesblåsor. ${ }^{442}$ Borelius utgick från det referat som The

\footnotetext{
438 Godard 1857, Études sur la Monorchidie...

${ }^{439}$ Ramm 1895, s. $3-4$.

${ }^{440}$ Ramm 1896, s. 39.

${ }^{441}$ Ibid.

${ }^{442}$ Ramm 1895, s. 3.
} 
Lancets korrespondent i Paris gjort av Lanouis fynd att en individ som föddes med kryptorkism eller anorki saknade prostata. ${ }^{43}$ Hans försök att själv bekräfta detta misslyckades dock: i obduktionsprotokollen från Uppsala där testiklarna nämndes fanns inget om prostatan och vice versa. ${ }^{444}$

Läkaren Edwin Hurry Fenwick hade studerat den fysiologiska relationen mellan testiklarna och prostatan i tio år och samlat på sig ett antal fall med avvikande testiklar, och han hade sett en påverkan på prostatan när testiklarna inte hade vandrat ner i pungen. Han hade dock inte gjort sina observationer på avlidna patienter genom obduktion utan genom rektal palpering med fingret på levande patienter, och han medgav att det inte var en helt säker metod att avgöra prostatans tillstånd. När det gällde kryptorkism beskrev Hurry Fenwick kortfattat två fall. I båda fallen hade testiklarna kunnat lokaliseras i den nedre delen av buken men varit mycket små, och i båda fallen var prostatans två lober lika stora. I det ena fallet var dock prostatan som helhet mycket liten och i det andra fallet drabbades patienten av prostatacancer och Hurry Fenwick anger inte hur stor prostatan var. ${ }^{445}$

Det fanns alltså observationer som visade på olika effekter av kryptorkism och anorki. Hos vissa patienter saknades prostatan helt eller var outvecklad, hos andra saknades förutom prostatan även andra delar av det urogenitala systemet som sädesblåsor, och ytterligare andra hade missbildningar i omkringliggande strukturer. Det var alltså svårt att dra en entydig slutsats om hur testiklarna påverkade prostatan om de saknades från födseln eller inte hade vandrat ner hela vägen till pungen. Ändå intresserade dessa fall ett antal av de läkare och kirurger som debatterade kastrering som behandling vid prostatahypertrofi. I debatten syns en pågående kunskapsproduktion där vissa spår, som eunucker och

\footnotetext{
443 "PARIS." 1894, s. 468

${ }^{444}$ Borelius 1897a, s. 283.

${ }^{445}$ Fenwick 1895a, s. 529.
} 
eunuckism, var mer fruktbara än kryptorkism och anorki. Resonemangen om kryptorkism och anorki fördes framför allt under den tidiga delen av debatten, fram till 1897, för att sedan försvinna. De var ett av alla de försök som gjordes att använda sig av all den kunskap som fanns om olika tillstånd som påverkade testiklarna för att reda ut frågan om kastrering som behandling mot prostatahypertrofi.

\section{Påverkan på kroppen under puberteten}

Läkare och kirurger som deltog i kastreringsdebatten intresserade sig även för hur kryptorkism och anorki påverkade utvecklingen av kroppen från barn till vuxen. Joseph Griffiths hade studerat kryptorkism noga och skrev:

In spite, however, of the imperfection of the organs, such a person acquires all the external bodily characteristics of the male and is in all respects, except in the power of procreation, like an ordinary man. His shoulders are broad, his pelvis is narrow, his beard and moustache and hair on the pubes are well grown, his voice is deep and manly, and his penis is large and well developed, though the scrotum is small and empty; so that the external appearance, except that of the scrotum, would give no clue to the condition. ${ }^{446}$

Anorki finns det färre beskrivningar av, men att det ansågs svårt att diagnostisera tyder det faktum på att flera personer som vid obduktion visade sig sakna testiklar inte till det yttre skilt sig från kryptorkider. Vissa av dem utvecklade dock eunuckism.

Att kryptorkider inte avvek från "normala" män på något annat sätt än att de saknade testiklar i pungen - och enligt vissa var sterila, vilket jag strax kommer till - är en av anledningarna till att de aldrig ansågs vara något annat än män. Sedan i alla fall sent 1700-tal hade det i Sverige inte funnits något lagligt hinder

${ }^{446}$ Griffiths 1895c, s. 798. 
för kryptorkider att räknas som män och ingå äktenskap "så länge de visat sig vara i verkan av sin 'manlighet", det vill säga kunde genomföra ett penetrerande samlag. ${ }^{447}$ Perioden mellan 1870-talet och 1930-talet har Alice Domurat Dreger kallat "The Age of Gonads", en period då könskörtlarna betraktades som "the markers of true sex". ${ }^{448}$ Domurat Dregers studie handlar främst om hermafroditer, en grupp som på många sätt användes på ett liknande sätt som de avvikande männen i detta kapitel. Hermafroditer studerades både för att det ansågs viktigt att kunna dela in alla människor i "män" och "kvinnor" och för att läkare och kirurger ansåg sig kunna producera kunskap om den "normala" kroppen och dess utveckling genom att studera de avvikande. ${ }^{49}$ Som medicinsk kategori hade hermafroditism försvunnit nästan helt i slutet av 1800-talet, men dessa personer ansågs fortfarande inte vara "normala".

Hos kryptorkider fanns testiklarna i kroppen även om de inte vandrat ner i pungen, vilket var ett tydligt bevis på att de var män. Vid misstänkt anorki kunde testiklarnas vara eller icke-vara inte avgöras förrän efter personens död. Flera sådana individer verkar dock ha uppvisat tillräckligt tydliga sekundära könskaraktärer för att aldrig ifrågasättas som män. ”By the end of the nineteenth century, the gonadal definition of true sex meant that 'truth' was determined by the nature of the gonads, even if that 'truth' were invisible and unsuspected in a living patient", skriver Domurat Dreger. ${ }^{450}$ Hon menar att detta inte vilade på en rationell och vetenskaplig grund utan var ett pragmatiskt sätt att se till att alla kunde delas in i "män" och "kvinnor" oavsett hur tvetydiga deras biologiska kön eller beteende var, i en tid då osäkerhet beträffande biologiskt kön upplevdes som ett hot. ${ }^{451}$

\footnotetext{
447 Bondestam 2010, s. 130.

448 Domurat Dreger 2000, s. 151.

449 Bondestam 2010, s. 173.

450 Domurat Dreger 2000, s. 150.

${ }^{451}$ Ibid, s. 153.
} 


\section{Påverkan på fertiliteten}

Det fanns olika åsikter om fertiliteten hos personer utan testiklar i pungen. Det var klarlagt att testiklarna behövdes för att producera spermier och att de som saknade testiklar helt var sterila, men hur var det med dem som hade testiklar i till exempel nedre delen av buken? Fransmannen Champonnière ansåg, enligt Ramm, att alla som led av kryptorkism var sterila. Ramm menade att alla inte var det, men många. 452 White skrev: "When both testicles fail in their descent they are incapable of producing spermatozoa, and in consequence the person is sterile." ${ }^{453}$ Han tillade dock att Hunter, Astley, Cooper, Curling, Griffiths och andra hade visat att det fanns undantag. ${ }^{454}$ Enligt Griffiths, som ägnat mycket tid åt att studera testiklarna och deras funktion, var problemet att när testiklarna inte vandrade ner helt så uppnådde de inte heller full storlek eller full funktion, och alla de personer med kryptorkism han själv hade observerat hade varit sterila. 455

Enligt Griffiths var män som led av kryptorkism som män på alla sätt förutom att de var sterila och hade en tom pung, och han hade undersökt en man med kryptorkism som kunde få erektion och utlösning, men utan spermier. ${ }^{456}$ "And the remarkable fact", skrev Griffiths, var att detta visade att testiklarnas förmåga att producera spermier inte var nödvändig för utvecklingen av kroppen under puberteten. ${ }^{457}$ På grund av dessa observationer skilde han utvecklingen av manliga sekundära könskaraktärer från testiklarnas funktion att producera spermier. Det var till stor del dessa resultat och spekulationer som White lutade sig mot i sin artikel i juli samma år där han utvecklade sitt resonemang om

\footnotetext{
452 Ramm 1896, s. 38.

453 White 1895 d, s. 3.

${ }^{454}$ Ibid.

${ }^{455}$ Griffiths 1895c, s. 795, 798.

456 Ibid, s. 798.

457 Ibid.
} 
testiklarnas tvåfaldiga funktion och deras påverkan på den manliga kroppen som jag diskuterade i kapitlet "Prostatan, prostatahypertrofi och dess etiologi" ${ }^{458}$

Resonemanget om testiklarnas påverkan på den vuxna manliga kroppen bottnade på många sätt i resonemang om reproduktion, särskilt testiklarnas produktion av spermier. Dels hade testiklarnas funktion som producenter av spermier varit känd mycket längre, och dels hade många framhållit den som viktigare än andra möjliga funktioner hos testiklarna. White skrev 1895 att testiklarnas "highest and most specialized function is to produce spermatozoa for the propagation of the species". ${ }^{459}$ Griffiths betonade samma år att testiklarnas främsta funktion var "the formation of the special and most power-giving cells in the animal kingdom - the spermatozoa". ${ }^{460}$ Detta var den gängse synen på testiklarna hos läkare under mitten av 1890-talet.

Det var därför Griffiths efter sina studier av kryptorkism fann det "remarkable" att spermieproduktionen och testiklarnas mer allmänna påverkan på kroppen kanske inte hade något med varandra att göra. Detta var vid en tid då injektioner av ett extrakt på testiklar ansågs göra män vitala igen och föreställningar om "the spermatic economy", alltså att män riskerade att bli försvagade om för mycket sperma lämnade kroppen, påverkade synen på onani och sex. ${ }^{461}$ Charles Édouard Brown-Séquard hade 1869 föreslagit att injektioner med spermier skulle kunna bromsa äldre mäns åldrande. Tjugo år senare hade han enligt Timothy Verhoeven förändrat idén något och menade att testiklarna innehöll någon form av uppiggande substans och injicerade sig själv med detta testikelextrakt. ${ }^{462} \mathrm{Jag}$ kommer att återkomma till detta resonemang i kapitlet om kastrering av kvinnor och män och utveckla vad dessa injektioner ansågs vara.

\footnotetext{
458 White 1895 d, s $3-8$.

459 Ibid, s. $2-3$.

${ }^{460}$ Griffiths 1895b, s. 792.

461 Stolberg 2000, s. 57.

462 Verhoeven 2017, s. 95.
} 
Mäns spermier ansågs i alla fall fram till slutet av 1800-talet påverka deras kroppar genom att ge dem kraft och energi; att slösa med dem ledde till ohälsa och kraftlöshet. Att män med kryptorkism utvecklades till "riktiga män" förutom att de ofta var sterila motsade dessa resonemang.

Testiklarna som kunskapsobjekt var tydligt fysiskt avgränsade, men åsikterna om deras funktion gick isär. Det var klart att de spelade en roll i den pubertala utvecklingen, men oklart exakt hur det gick till. Det var också tydligt att en av deras viktigaste funktioner var att producera spermier. Spermierna avskildes dock från själva testikelvävnaden och hade egna funktioner. De var i sig själva kunskapsobjekt som studerades för att undersöka dess inverkan på den manliga kroppen och bidra till kunskapsproduktionen kring det manliga urogenitala systemet, dess funktion och dess påverkan på kroppen.

\section{Monorkism och ensidig kastrering}

Monorkism, alltså att endast en testikel hade vandrat ner i pungen, intresserade läkare och kirurger i kastreringsdebatten mycket eftersom det öppnade för ensidig kastrering. Om testiklarna kunde visas ha en direkt inverkan på den motsvarande halvan av prostatan kunde ensidig kastrering i många fall räcka för att bota prostatahypertrofi. Monorkism innefattar både att en testikel saknas helt eller att en testikel inte vandrat ner.

Ramm hade behandlat en patient som inkommit till sjukhuset i Tromsø med en tumör i buken. Det visade sig att han bara hade en testikel i pungen, den vänstra, och att tumören i buken var den högra testikeln som inte vandrat ner. Ramm undersökte även patientens prostata och kunde konstatera att den var asymmetriskt utvecklad: den högra sidan var mycket mindre. Ramm medgav att det var svårt att känna prostatans yttre kanter vid en rektal undersökning på en levande patient, och därför var han något osäker på sin bedömning av prostatans form. När den högra testikeln opererats bort och han undersökte prostatan tycktes 
den vara likadan som före operationen. ${ }^{463}$ Att operera bort den testikel som inte vandrat ner verkade alltså inte påverka prostatan.

Både White och Ramm hade läst om en patient som endast hade en nedvandrad testikel, den högra, men som uppgavs ha haft normala ejakulationer. Patienten avled vid tjugo års ålder och vid obduktionen hittades den vänstra testikeln i nedre delen av buken. Den var inte fullt utvecklad och var mindre än den högra. Prostatan var asymmetriskt utvecklad: den vänstra halvan var betydligt mindre än den högra. Hos denna patient var även sädesblåsorna asymmetriskt utvecklade: den högra innehöll spermier men inte den vänstra. Ett annat liknande fall som både White och Ramm återgav rörde en man i 40-årsåldern som hade en icke nedvandrad testikel och en asymmetriskt utvecklad prostata och sädesblåsor. ${ }^{464}$

White lutade sig mot Godard och menade att denne hade visat att när en testikel inte utvecklades eller inte vandrade ner helt så genomgick prostatan och sädesblåsan på motsvarande sida atrofi. ${ }^{465}$ Han hävdade att andra hade gjort samma observation och att sambandet nu var klarlagt. ${ }^{466}$ Edwin Hurry Fenwick rapporterade om två fall där prostatan på den sidan som motsvarade den saknade testikeln var platt eller atrofierad. Han påpekade dock att dessa observationer var gjorda genom rektal palpering, en långt ifrån felfri metod. "Moreover, none of us know the normal shape of the prostate, for it varies with each decade and with each individual", tillade han. ${ }^{467}$

Testiklarna verkade ha en direkt inverkan på den motsvarande halvan av prostatan. Att avlägsna endast en testikel skulle alltså kunna föreslås för de

463 Ramm 1896, s. 39.

${ }^{464}$ Ramm 1896, s. 39.; Ramm 1895, s. 3; White 1895d, s. 37 - 38; "PARIS.” 1894, s. 468.

${ }^{465}$ White 1895d, s. 37. Jag har dock inte kunnat verifiera detta vid min genomsökning av Godards publikation.

466 White 1895d, s. 38.

${ }^{467}$ Fenwick 1895a, s. 529. 
patienter som hade en förstoring av den ena prostataloben. Men som ofta i debatten om kastrering hade Charles Mansell Moullin en annan åsikt och hävdade att sambandet inte var så absolut: "If one testis fails to develop, owing to non-descent or other causes, occasionally the corresponding half of the prostate and the vesicular seminalis fail too; but not in the majority of instances." 468 Även Borelius påpekade att detta samband inte alltid stämde. På Anatomiska museet i Uppsala hade han hittat ett intressant preparat där den vänstra testikeln, sädesledaren och sädesblåsan saknades helt men prostatan ändå hade två fullt utvecklade lober. ${ }^{469}$ (se sid. 175)

Ibland tycktes det finnas en direkt påverkan mellan en testikel och den motsvarande sidan av prostatan, men inte alltid. Läkarna och kirurgerna i materialet noterade att det fanns fall där den andra testikeln saknades helt och fall där den fanns någon annanstans i kroppen, men i diskussionen gjorde de ingen skillnad mellan dessa fall. Båda tillstånden räknades som monorkism, och det diskuterades aldrig om det gjorde någon skillnad i påverkan på prostatan om den andra testikeln fanns i till exempel ljumskkanalen eller om den saknades helt.

${ }^{468}$ Charles Mansell Moullin, Enlargement of the Prostate. Its Treatment and Radical Cure, London H K. Lewis, Tredje utgåvan, 1904, s. 189. Första upplagan publicerades 1894. Enligt "Reviews and Notices of Books", The Lancet, vol 154, nr. 3976 (ursprungligen publicerad som volym 2, nr. 3976) nov. 11, 1899, s. 1304, så var det i upplagan som utkom samma år som kapitlet om avlägsnandet av en eller båda testiklarna och dess effekt på prostatan lagts till. ${ }^{469}$ Borelius 1897a, s. $283-284$. 


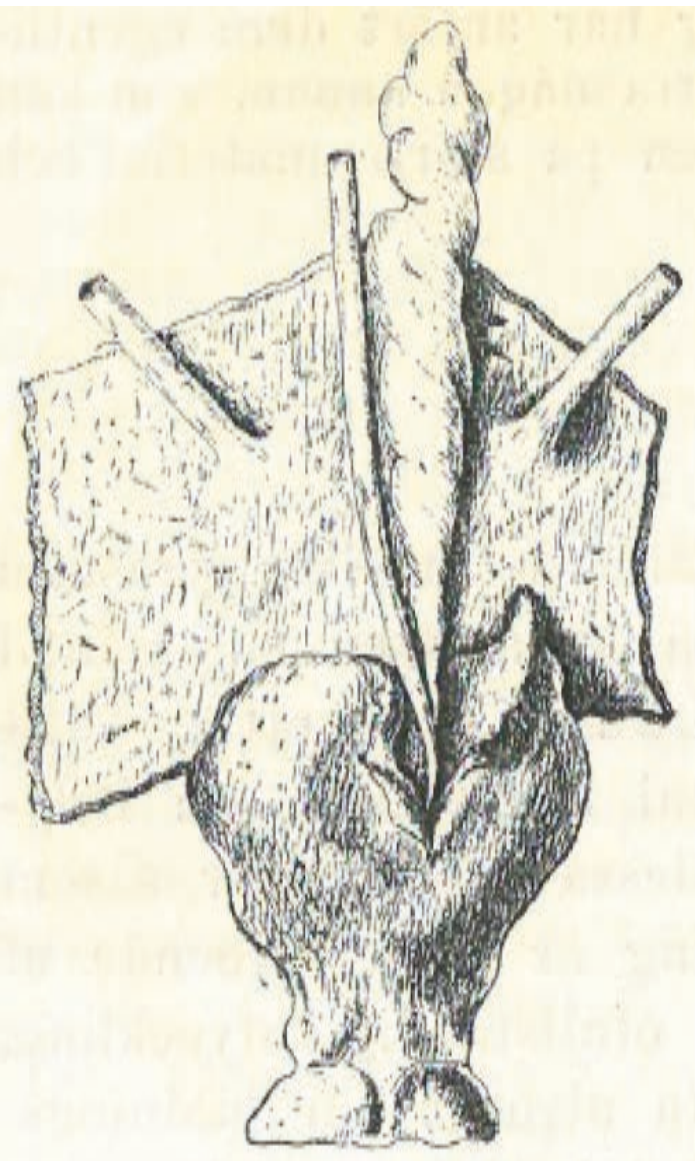

Fig. 13.

Källa: Jaques Borelius, "Bidrag till den s. k. prostatahypertrofiens patologi och terapi”, Del 1, Hygiea, band 59, del1, februari, 1897, s. 284.

Kategorin personer med monorkism skapades till mycket större del än kryptorkism och framförallt anorki genom undersökningar av levande patienter. Att palpera pungen och känna om det fanns någon testikel där eller inte var enkelt. Det som fick vänta till obduktion i vissa fall var att avgöra om den andra testikeln fanns någonstans $\mathrm{i}$ kroppen eller om den saknades helt, men skillnaden betraktades inte som avgörande. Även prostatan kunde palperas genom rektal 
undersökning för att läkaren skulle kunna avgöra om den utvecklats normalt eller om den var asymmetrisk. Män med monorkism var dessutom ännu mindre ifrågasatta som fullständiga män, än eunucker och eunuckoider eftersom de hade en fullt fungerande testikel och därmed inte bara utvecklades "normalt" under puberteten utan dessutom var fertila.

\section{Skadade och sjukliga testiklar}

Förutom medfödda tillstånd kunde en hel del hända med testiklarna under livet. De kunde atrofiera till följd av lokala varbildningar och infektioner; Ramm menade att de testikelinflammationer som ofta följde på påssjuka resulterade i atrofi av testiklarna $i$ en tredjedel av fallen. Hur denna form av testikelinflammation påverkade prostatan och prostatans utveckling var inte känt enligt Ramm, men han menade att en påverkan kunde finnas. ${ }^{470}$ Även sexuellt överförbara sjukdomar kunde medföra en atrofiering av en eller båda testiklarna. Upprepade testikelinflammationer till följd av gonorré hade observerats leda till ensidig testikelatrofiering, och till en halvsidig atrofiering av prostatan som kopplades till atrofieringen av testikeln. Även vid medfödd syfilis (som överfördes från modern till fostret) hade atrofi av testiklarna och prostatan observerats. ${ }^{471}$ Edwin Hurry Fenwick rapporterade om ett antal patienter som hade drabbats av mycket tydlig atrofi av en eller båda testiklarna på grund av en inflammation eller av okänd orsak. Han hade dock inte funnit något tydligt samband mellan detta och en atrofiering av prostatans motsvarande lob. Istället förekom i några av fallen motsatt effekt på prostatan, att den sidan som hade en atrofierad testikel var förstorad. Hurry Fenwick påpekade att hans observationer gick emot de slutsatser White dragit om atrofierade testiklars påverkan på prostatan. ${ }^{472}$ Precis som vid

\footnotetext{
470 Ramm 1896, s. 40.

${ }^{471}$ Ramm 1896, s. 40; Ramm 1895, s. 4

472 Fenwick 1895a, s. 529.
} 
studierna av personer med monorkism fanns det här resultat som pekade åt olika håll.

Mansell Moullin hade gjort observationer som gick emot Whites slutsatser om den ensidiga påverkan på prostatan när en av testiklarna atrofierat eller avlägsnats. Han menade att det kunde påverka prostatan om en testikel förstördes eller skadades under spädbarnstiden, men långt ifrån alltid. ${ }^{473}$ Detsamma gällde om en testikel drabbades av testikelinflammation och atrofierade: det ledde i vissa fall, men inte i de flesta, till att den motsvarande halvan av prostatan atrofierade. Det fanns till och med flera fall där motsatt effekt rapporterades, alltså att den motsvarande sidan av prostatan blev förstorad. ${ }^{474}$ När det gällde risken för förändringar av de sekundära könskaraktärerna hos män hävdade Mansell Moullin att det inte fanns några bevis för att sjukliga förändringar av testiklarna kunde orsaka detta efter puberteten. ${ }^{475}$ Därför, menade Mansell Moullin, behövde man inte oroa sig för att kastrering skulle påverka de sekundära könskaraktärerna hos vuxna män. 476

Det fanns alltså motsägelsefulla rapporter om hur testiklarna påverkade prostatan. I vissa fall verkade en saknad, sjuk eller skadad testikel medföra att motsvarande sida av prostatan atrofierade, men i vissa fall skedde ingen påverkan eller så förstorades prostataloben. Argumenten för att en ensidig kastrering skulle fungera som behandling mot prostatahypertrofi såg alltså något osäkra ut.

\section{Testiklarnas påverkan på prostatan}

Observationerna av eunucker och personer med kryptorkism, anorki och monorkism bekräftade på många sätt det som tidigare konstaterats om

\footnotetext{
${ }^{473}$ Mansell Moullin 1904, s. 189 - 190.

${ }^{474}$ Ibid, s. 189.

475 Mansell Moullin 1894b, s. 909.

476 Mansell Moullin 1894c, s. 976.
} 
förhållandet mellan testiklarna och prostatan. Om testiklarna saknades så utvecklades ingen prostata och om de skadades eller på något sätt avlägsnades så atrofierade prostatan. Det som var nytt var att ingen av testiklarna behövde vandra ner i pungen för att en "normal" utveckling av prostatan och resten av kroppen skulle ske. Kryptorkider utvecklades nämligen på alla sätt till "fullständiga män" även om testiklarna befann sig på andra ställen i kroppen. Deras testiklar utvecklades inte helt och därför var de oftast sterila, men trots att deras testiklar inte producerade spermier kunde de påverka kroppens utveckling under puberteten. Det var alltså inte spermierna som påverkade den manliga kroppens utveckling och virilitet.

En annan viktig slutsats av studierna av testiklarna var hur kroppens utveckling påverkades av att de saknades eller inte var fullt fungerande redan före puberteten. Observationer av eunucker visade att den pubertala utvecklingen, och prostatans utveckling, avvek från vad som ansågs vara "normalt" om testiklarna hade avlägsnats dessförinnan. Hos eunucker som hade kastrerats som vuxna atrofierade prostatan, men påverkan på kroppen blev en annan än om de hade kastrerats prepubertalt. På samma sätt visade eunuckoida personer att kroppen påverkades på ett liknande sätt av icke-fungerande testiklar som om de hade avlägsnats före puberteten. Det gick alltså att befästa att testiklarnas funktion, i alla fall den andra som inte hade med produktionen av könsceller att göra, var avgörande för utvecklandet av en prostata under puberteten. Vissa läkare och kirurger menade också att det gick att konstatera att man inte behövde vara orolig för att en liknande påverkan på kroppen skulle uppstå, som om personen kastrerats innan puberteten, om man kastrerade äldre män som led av prostatahypertrofi.

Alla dessa män som avvek från normen att ha två fullt utvecklade testiklar i pungen bidrog på olika sätt till kunskapsproduktionen kring möjliga effekter av kastrering som behandling vid prostatahypertrofi, och till en vidare förståelse av testiklarnas påverkan på prostatan. Resultaten var inte entydiga - till viss del 
tycktes tillståndet monorkism peka på att ensidig kastrering skulle kunna fungera för patienter med en asymmetriskt förstorad prostata, men å andra sidan fanns det ett antal fall som pekade på det motsatta. Vissa läkare och kirurger tyckte ändå att det var värt att prova ensidig kastrering för att se om det räckte. Henry Clarke föreslog att man alltid kunde avlägsna en testikel i taget, och hjälpte det inte att ta bort en kunde man operera bort den andra senare. ${ }^{477}$

Eunucker och personer med kryptorkism, anorki och monorkism användes för att argumentera för kastrering som behandling mot prostatahypertrofi. Främst var det hur de olika tillstånden och sjukdomarna som kunde drabba testiklarna kom till uttryck när det gällde påverkan på prostatan och kroppen i övrigt som var avgörande. De praktiker som skapade dessa kategorier fungerade också som agentiella snitt som producerade testiklarna som kunskapsobjekt som kunde manipuleras för att ge en effekt på prostatan.

${ }^{477}$ Henry E. Clarke "The Effects of Unilateral Castration on the Prostate" The British Medical Fournal, vol. 1, nr. 1784, mar. 9, 1895, s. 563. 


\section{Prostator hos djur}

Att läkare utförde experiment på patienter, på sig själva eller på djur var en gammal praktik inom medicinen. ${ }^{478}$ Sedan antiken hade dissektion (att skära upp och undersöka döda kroppar i vetenskapligt syfte, av människor såväl som djur) och vivisektion (att skära upp och undersöka levande djur), varit sätt att lära sig hur kroppen fungerar. Lika länge har det funnits ett motstånd mot både dissektion av döda människor och vivisektion av levande djur. ${ }^{479} \mathrm{I}$ och med framväxten av den moderna vetenskapliga metoden under 1600-talet fick djurexperimenten en allt mer framträdande plats i den medicinska kunskapsproduktionen. Även om djurexperiment använts tidigare för att skapa kunskap om kroppen utfördes de nu för att skapa specifik kunskap om biologiska processer. ${ }^{480}$ Under 1700-talet spelade djurexperiment en framträdande roll inom medicinska områden som farmakologi, elektrofysiologi och modern embryologi, men det skulle dröja en bra bit in på 1800-talet innan djurexperiment mer direkt kunde börja gagna den mänskliga hälsan. ${ }^{481}$ Metoden för de djurexperiment som genomfördes för att undersöka testiklarnas påverkan på prostatan hade växt fram ur denna utveckling

478 Erika Dyck and Larry Stewart (red.), The Uses of Humans in Experiment: Perspectives from the 17th to the 20th Century, Brill, Leiden, 2016.

479 Anita Guerrini, Experimenting with humans and animals: From Galen to animal rights, Baltimore: The Johns Hopkins University Press, 2003, s. 2-3, 7, 10 - 11.

480 Nuno Henrique Franco, ”Animal Experiments in Biomedical Research: A Historical Perspective", Animals, vol. 3, nr. 1, 2013, s. 244.

${ }^{481}$ Franco 2013, s. 245. 
och präglades därför av specifika ingrepp för att undersöka en specifik effekt, inte av mer allmänna studier av kroppens funktioner.

Den komparativa anatomin, alltså studiet av skillnader och likheter mellan olika arter, var en av de metoder som Hunter använde sig av och som flera av periodens läkare lutade sig emot i sina resonemang om kastrering. Bland andra Mansell Moullin undervisade i komparativ anatomi. ${ }^{482}$ Ett av de mest kända namnen under 1800-talet var den franske fysiologen Claude Bernard (18131878), som fortsatte på sin berömde lärares, den franske fysiologen François Magendies (1783-1855), bana med experimentell fysiologi. Som metod för att skapa kunskap om kroppen skulle den experientella fysiologin få ett stort genomslag. Bernards arbete resulterade $\mathrm{i}$ att den vid han död ansågs vara den främsta metoden. ${ }^{483}$ Dessa experiment innebar dissektion och vivisektion av djurkroppar.

I England hade det sedan början av 1800-talet funnits en stark antivivisektionsrörelse. Under första delen av 1800-talet utfördes nästan inga djurexperiment i England. ${ }^{484}$ Efter en lång process infördes i England 1876 års "Cruelty to Animals Act", vilket gjorde England till det första landet att genom lag försöka reglera djurexperiment. Djurexperiment var nu tillåtna, men innan de kunde utföras måste ansökningar lämnas in och godkännas och det fanns inskränkningar i vilka djur som fick användas. ${ }^{485}$ I Sverige kom djurexperiment att regleras långt senare. Fram till 1920-talet hade det funnits lagar som reglerade djurhållning, men inte djurexperiment. Först 1945 trädde den första djurskyddslagen i kraft vilken reglerade även olika former av experiment och andra vetenskapliga praktiker. ${ }^{486}$

482 O’Connor 1991, s. 273.

483 Guerrini 2003, s. $81-83$.

484 Ibid, s. $74-78$.

${ }^{485}$ Guerrini 2003, s. 87 - 90; Franco 2013, s. 252.

${ }^{486}$ SOU 1998:75, Djurförsök https://lagen.nu/sou/1998:75\#S2 [Sidan besökt 2019-10-16] 
De brittiska läkarna och kirurgerna som deltog i kastreringsdebatten hade alltså inte samma möjligheter att utföra djurexperiment som sina kollegor i Frankrike, Sverige, Tyskland och USA. De kunde dissekera döda djur men de kunde inte obehindrat experimentera på levande djur som sedan avlivades. Mansell Moullin kommenterade detta i en artikel 1893, där han konstaterade att det skulle vara möjligt att undersöka hur vildsvin och hundar påverkades av kastrering genom experiment, eftersom även de kunde drabbas av prostatahypertrofi, men att dessa experiment inte fick utföras i England. ${ }^{487}$

Både Magendie och Bernard var måltavlor för den engelska antivivisektionsrörelsen på grund av sina experiment på djur som sågs som både grymma och onödiga. De själva hade dock en helt annan syn på det hela. Antivivisektionsrörelsens anklagelser bottnade i en syn på att det var omoraliskt att utsätta oskyldiga djur för experiment för att gagna människor. Magendie och Bernard ansåg tvärt emot att det var omoraliskt att experimentera på människor innan ingreppen först testats på djur. Ur deras humanistiska perspektiv handlade det om att öka säkerheten för människor på bekostnad av djur, som inte förtjänade samma moraliska hänsyn som människor. ${ }^{488}$ Vissa läkare experimenterade främst på "lägre" djur, som fiskar och grodor. Bernard argumenterade för att använda djur som var så lika människor som möjligt, men inte så lika som primater vilka han vägrade att experimentera på. Han använde därför främst hundar. ${ }^{489} \mathrm{I}$ och med att djurexperiment användes allt mer uppstod också frågan på vilka sätt djur och människors kroppar faktiskt var lika och vilken kunskap detta kunde bidra med. ${ }^{490}$ Gick det att experimentellt undersöka påverkan mellan djurs testiklar och

487 Mansell Moullin 1893a, s. 655.

488 Franco 2013, s. 250.

489 Guerrini 2003, s. 86, 117.

${ }^{490}$ Lindsay Granshaw, "Knowledge of Bodies or Bodies of Knowledge? Surgeons, anatomists and rectal surgery, 1830 - 1985", Christopher Lawrence (red.), Medical theory, surgical practice: studies in the history of surgery, Routledge, London, 1992, s. 241. 
prostata och överföra denna till människor? Djurexperiment och vilka kunskaper som kunde skapas på detta sätt var en viktig del i den medicinska kunskapsproduktionen och i produktionen av prostatan och testiklarna som kunskapsobjekt, men det var inte helt självklart vilka slutsatser som kunde överföras.

Inom medicin eftersträvas många gånger materiellt-diskursiva förklaringar till sjukdomar eller försvar av behandlingar. Det bör finnas empirisk evidens och en teoretisk förklaring till dessa. Idealet är alltså en semiotisk förklaring som överensstämmer med den materiella verkligheten. Någon sådan finns inte alltid, som vi såg i analogin mellan uterusmyom och prostatahypertrofi. För de läkare och kirurger som deltog i kastreringsdebatten fyllde djurförsöken en viktig funktion i den materiellt-diskursiva praktiken. De fynd som gjordes vid djurexperimenten var resultaten av en intra-aktion mellan subjektet (läkaren, kirurgen eller anatomen), apparaterna (mikroskop, okulärbesiktning, skalpeller, kontrastvätska etc.) och objektet (djurens prostata). Lika mycket som subjektet påverkade synen på kastreringens påverkan på prostatan, lika mycket påverkade de instrument som användes och de prostator som undersöktes.

Läkare och anatomer, som Magendie och Bernard, vilka experimenterade på djur gjorde ett agentiellt snitt mellan människor och djur som innebar att de ansåg att det var oansvarigt att inte experimentera på djur innan ett ingrepp utfördes på människor. Samtidigt var det inte acceptabelt för vissa att experimentera på djur som var för lika människor, som primater, vilket tyder på att det agentiella snittet inte placerade alla djur i den "avlivningsbara" delen av spektrumet. Många föredrog djur som befann sig längre från människor på den tänkta skalan, vilket Tara Mehrabi har funnit gäller även i moderna experiment med bananflugor. ${ }^{491}$ Anti-vivisektionsrörelsens agentiella snitt gjorde däremot att exempelvis hundar, som föredrogs av många läkare och anatomer vid experiment,

491 Mehrabi 2016, s. 179. 
inte hamnade inom delen "avlivningsbara". De som utformade den lag i England som reglerade djurexperimenten gjorde ytterligare ett annat agentiellt snitt, som innebar att vissa djur som läkare och anatomer hade velat experimentera på skyddades och vissa djur som antivivisektionsrörelsen hade velat skydda blev tillåtna att experimentera på. Lagen stadgade dock främst att dessa djur fick utsättas för experiment och avlivas på vissa villkor, som att de bedövades eller sövdes innan experiment eller avlivning. ${ }^{492}$

\section{Experiment på djurprostator}

Redan innan kastrering föreslogs som behandling mot prostatahypertrofi hade det genomförts en del djurexperiment och dissektioner i syfte att ta reda på prostatans funktion och effekten av kastrering och vasektomi. Hunter hade genomfört studier och experiment på djur, och det var också han som ansågs ha upptäckt att de sexuella körtlarna, däribland prostatan, hos vissa fåglar och däggdjur förändrades under året. ${ }^{493}$ Detta fångade intresset hos Joseph Griffiths som genomförde experiment på mullvadar och igelkottar redan 1889 för att studera hur prostatan förändrades mellan brunsten och den del av året då de sexuella körtlarna var som minst aktiva, det han kallade det aktiva respektive det inaktiva stadiet. ${ }^{494}$ Griffiths intresse för kastreringens påverkan på prostatan gjorde att han i samma artikel från 1889 redogjorde för sina resultat av kastrering av hundar och katter samt för vad som var känt om män som kastrerats av andra orsaker än för att behandla prostatahypertrofi. ${ }^{495}$

492 Guerrini 2003, s 90.

${ }^{493}$ Joseph Griffiths, "Observations on the Function of the Prostate Gland in Man and the Lower animals", Fournal of Anatomy and Physiology, vol. 24 (Pt1), okt. 1889b, s. 28.

${ }^{494}$ Griffiths 1889b, s. 27

495 Ibid, s. $27-41$. 
Djur hade kastrerats under hundratals år för att kontrollera reproduktionen och mildra exempelvis hingstars och tjurars temperament. Återigen verkar det ha varit Hunter som först beskrev de effekter detta hade på reproduktionsorganen. Hunter hade undersökt tjurar, och när Griffiths gjorde detsamma bekräftade han resultaten. Till detta lade Griffiths studier av förändringar hos grisar, tjurar, får och hästar efter kastrering. ${ }^{496}$ Även Ramm framhöll att det var välkänt att prostatan skrumpnade eller stannade i växten om man kastrerar djur tidigt, han hade frågat en slaktare på svinslakteriet i Kristiania, och denne kände till att det förhöll sig så. ${ }^{497}$

Den brittiske läkaren James MacMunn gjorde ändå 1893 bedömningen att man inom veterinärvetenskapen fortfarande hade alltför dåliga kunskaper om prostatahypertrofi, något som förvånade honom med tanke på vilken uppmärksamhet som hade ägnats området. De djurexperiment som utförts på hundar räckte inte enligt MacMunn för att visa på den effekt kastrering hade på prostatan. Inte heller hade ålder undersökts i relation till kastrering, vilket han menade kunde avgöra om det var kopplingen mellan testiklarna och prostatan vid kastrering som gjorde att prostatan atrofierade eller om det var förlusten av libido och möjligheten att prestera sexuellt. ${ }^{498}$

Djurexperimentens långa historia inom medicinen hade kringgärdats av en hel del diskussioner. Förutom motståndet mot vivisektion och debatter om vad dissektioner egentligen kunde ge för kunskap om kroppen, hade det förekommit försök att etablera riktlinjer för hur djurexperiment borde gå till. Marie François Xavier Bichat (1771-1802), fransk anatom och patolog, hade under slutet av 1700-talet ställt upp ett antal kriterier för djurexperiment vilka inspirerade Magendie och flera andra i hans generation. I korthet menade Bichat att eftersom

496 Griffiths 1889b, s. $32-35$

497 Ramm 1895, s. 4.

498 MacMunn 1893, s. 709. 
experiment på levande djur var svåra att kontrollera behövdes det stränga regler och noggrannhet. Det räckte inte med att studera experimentdjuret utan det måste jämföras med ett normalt djur. I detta fall skulle man till exempel jämföra ett kastrerat djurs prostata med ett okastrerat djurs. Det var också viktigt att kontrollera experimentsituationen för att inte yttre faktorer skulle påverka resultatet. För att kunna presentera säkra resultat behövde experimentet upprepas flera gånger, och det var viktigt att djuret undersöktes noggrant före och under experimentet. ${ }^{499}$ Som vi kommer att se influerade Bichats kriterier fortfarande djurexperimenten ett sekel senare.

\section{Valet av experimentdjur}

För den som ville utföra djurexperiment var en av de första frågorna vilka djur som skulle användas. Bernard hade tidigare under 1800-talet argumenterat för hundar eftersom de var mer lika människor än andra djur, förutom primater, som han vägrade experimentera på för att de tvärtom var alltför lika. 500 Även för en av de främsta förespråkarna för djurexperiment fanns det alltså gränser för vilka djur det gick att experimentera på. Det uppstår en intressant spänning mellan strävan att välja ett djur som liknar människan, för att få så tillförlitliga resultat som möjligt, och viljan att undvika alltför människolika djur på grund av de moraliska och etiska problem som likheten gav upphov till.

Även i kontexten "medicinska experiment" behövde djuren vara avlivningsbara. De lagar och restriktioner som styrde vilka djur man fick experimentera på, och på vilket sätt, behövde stämma överens med vilka djur läkaren, kirurgen eller anatomen själv kunde tänka sig att experimentera på och avliva. Vi kan tänka oss att djur kan placeras in på ett spektrum skapat av läkare och kirurger, där "experimentdjur" utgör en del av spektrumet. Dessa djur kan ta

499 Guerrini 2003, s. 71 - 72; Franco 2013, s. 247.

500 Guerrini 2003, s. 86, 117. 
människans plats vid försök och experiment med nya operationsmetoder och liknande. När det gällde kastrering som behandling mot prostatahypertrofi var det viktigaste att experimentdjurens prostata och dess koppling till testiklarna sågs som jämförbara med människans.

Gränsdragningen, det agentiella snittet, mellan människa och djur var inte helt självklar när det gällde djurexperiment. I många historiska fall har det funnits en glidande och oklar skala, ett spektrum, även när det gäller medicinska experiment på människor. Vissa grupper av människor har det varit omoraliskt och oetiskt att experimentera på, men vissa har hamnat på den andra sidan det agentiella snittet och utsatts för experiment. Anstaltspatienter i Sverige utsattes för experiment med klibbig kola och annat godis för att studera effekterna på deras tänder; afro-amerikanska män med syfilis i USA vägrades behandling under ett 40 år långt experiment; och rasifierade kvinnor utsattes för storskaliga experiment med tidiga hormonella preventivmedel i Puerto Rico. ${ }^{501}$ Det finns således ett spektrum även för människor. Vissa människor har betraktats som mer människor än andra, deras liv mer värda och deras lidande mer oetiskt. Avlivningsbarhet är inte en faktor på samma sätt som då djur dödas för att undersökas, men experimenten har i vissa fall resulterat i människors död för den medicinska vetenskapens skull.

Även i slutet av seklet betraktades hundar som bra djur att experimentera på. Vid dissekering verkar många läkare och anatomer ha dissekerat alla djurkroppar de kom över. MacMunn intresserade sig för prostatans funktion och under många år dissekerade han ett stort antal djur av olika arter. ${ }^{502}$ När det gällde

${ }^{501}$ Elin Bommenel, Sockerförsöket: kariesexperimenten 1943 - 1960 på Vipeholms sjukhus för sinnesslöa, (Diss.) Arkiv, Lund, 2006; Susan M. Reverby, Examining Tuskegee: the infamous syphilis study and its legacy, University of North Carolina Press, Chapel Hill, 2009; Suzanne States \& Lara Marks, "Women's Trials: The Approval of the First Oral Contraceptive Pill in the United States and Britain”, Oxford university Press vol. 57, 2002, s. 117 - 160.

502 MacMunn 1892, s. 328. 
experiment som rörde kastreringens påverkan på prostatan menade vissa läkare dock att det fanns anledning att föredra vissa djur framför andra.

När Freyer hade genomfört 110 prostatektomier på människor och undersökt de prostator han opererat bort konstaterade han att prostatan hos människor bestod av två sammanväxta körtlar. I fosterstadiet var de distinkt åtskilda hos människan och växte sedan samman medan de hos vissa lägre djur förblev åtskilda hela livet. ${ }^{503}$ Freyer hävdade att detta var helt ny kunskap om prostatan men Mansell Moullin hade fört fram denna åsikt i en artikel redan 1896. ${ }^{504}$ Enligt honom var prostatan i grunden ett dubbelt organ, hos människan liksom hos många lägre djur. Hur mycket en testikel påverkade den motsvarande halvan av prostatan vid ensidig kastrering torde vara beroende av i vilken grad prostatans två halvor var sammanväxta. Att utföra experiment på djur där prostatans två delar inte var lika sammanväxta som hos människan kunde inte ge korrekta resultat, menade Mansell Moullin. ${ }^{505}$

Han hävdade även att hundar och vildsvin hade visat sig kunna lida av en liknande hypertrofisk förändring som människor, vilken hos hundar gav upphov till liknande symptom som kunde botas med kastrering. ${ }^{506}$ Prostatan hos dessa två djur var så pass lik den mänskliga prostatan att Mansell Moullin placerade dem bland "experimentdjuren" i spektrumet.

Det agentiella snittet för prostatan som objekt gjordes alltså något annorlunda för människor och vissa djur. Hos människor gjordes snittet så att

\footnotetext{
503 Peter Johnston Freyer, "110 Cases or Total Enucleation of the Prostate for Radical Cure of Enlargement of that Organ", The Lancet, vol. 164, nr. 4221 (ursprungligen publicerad som volym 2, nr. 4221) juli 23, 1904, s. 197.

504 Charles William Mansell Moullin, "Unilateral Orchotomy for Enlargement of the Prostate", The Lancet, vol. 147, nr. 3779 (ursprungligen publicerad som volym 1, nr. 3779) feb. 1, 1896b, s. 288.

505 Mansell Moullin 1896b, s. 288.

506 Mansell Moullin 1893a, s. 655; Mansell Moullin 1896a, s. 115.
} 
prostatan var en körtel, om än sammanväxt av två delar, och hos vissa djur var den istället två skilda körtlar. Prostatan som kunskapsobjekt skapades på olika sätt beroende på hur den uppfattades som materiell struktur och dess relation till kringliggande strukturer. En sammanväxt eller två distinkt skilda körtlar, påverkad av brunstsäsonger eller inte. Dessa skillnader i kunskapsobjektens avgränsning påverkade hur resultaten av dissektioner och experiment på djur tolkades. Man eftersökte prostator hos djur där de agentiella snitten liknade dem som gjorts för prostatan hos människan.

Joseph Griffiths passade på att genomföra experiment med kastrering av hundar när han befann sig i Paris i juni 1890. ${ }^{507}$ Fransmannen Pavone valde också hundar för sina experiment med kastrering, och likaså Ramm och White, med motiveringen att hundar kunde drabbas av prostatahypertrofi. ${ }^{508}$ Precis som tidigare när det gällde prostataförstoringens orsaker och hur den bäst kunde behandlas så var Harrison av en annan åsikt. Han kände inte till något djur vars prostata genomgick en liknande förändring som vid prostatahypertrofi. ${ }^{509}$ Vidare menade han att man inte borde lägga allt för mycket vikt vid djurexperiment:

The moral influence of certain conditions and the material changes they give rise to, so far as they relate to the genital function in the human male, find no counterpart in the animal species as far as I have been able to ascertain. ${ }^{510}$

${ }^{507}$ Joseph Griffiths, "An Enlarged Prostate Gland Eighteen Days After Castration”, The British Medical fournal, vol. 1, nr. 1785, mars 16, 1895a, s. 581. 508”An Epitome of Current Medical Literature", The British Medical fournal, vol. 2, nr. 1801, jul. 6, 1895c, s. 2; Ramm 1896, s. 30; White 1893, s. 182 - 184.

${ }^{509}$ Harrison 1895, s. 1605.

510 Harrison 1896a, s. 474. 
Det fanns enligt Harrison heller ingen likhet mellan en förstorad prostata hos ett djur i brunst och hos en 70-årig man. ${ }^{511}$ Där de flesta läkare såg likheter mellan människor och djurs kroppar som gjorde att vissa kunde användas för att förstå den mänskliga kroppen, så betraktade Harrison skillnaden i var det agentiella snittet gjordes hos djur och människor - en eller två prostatakörtlar - som avgörande för om jämförelser var möjliga. Även den funktion som tillskrevs prostatan skilde sig åt mellan människor och vissa djur. Människor kunde para sig när som helst under året och hade inte en prostata som påverkades av brunst och inaktivitet, medan djur kunde ha en rudimentär prostata under den inaktiva delen av året som växte till och fick en reproduktiv funktion under brunsten.

För de flesta läkare som experimenterade med djur för att undersöka kastreringens påverkan på prostatan föll alltså valet på hundar, vilket är intressant ur flera aspekter. Att de passade för att undersöka kastreringens påverkan på prostatan motiverades främst med att prostatan hos hundar var sammanväxt, som den manliga prostatan, men också med att hundar ansågs kunna lida av prostatahypertrofi. På detta sätt passades de in i den del av spektrumet som utgjordes av möjliga experimentdjur. Ingen av de läkare som genomförde experiment på hundar uppgav dock att hundarna i deras experiment faktiskt led av prostatahypertrofi. För att hundars prostator skulle betraktas som en möjlig ersättning för den manliga prostatan räckte det med att de kunde drabbas av hypertrofi.

Hundar hade vid den här tiden länge varit ett populärt sällskapsdjur. ${ }^{512}$ Att många hundar, men inte alla, hamnade i kategorin sällskapsdjur, hindrade alltså inte läkare, anatomer och andra från att se dem som exemplariska experimentdjur. Närheten till människan var för dem inte ett etiskt eller moraliskt dilemma på samma sätt som primaternas fysiologiska likhet med människor. Det

511 Harrison 1895, s. 1605.

512 Guerrini 2003, s. 75. 
agentiella snitt som avgjorde vilka djur som var avlivningsbara påverkades alltså inte av djurens närhet till människan eller förmåga till samlevnad eller kommunikation. Det ska också tilläggas att det för många inom antivivisektionsrörelsen till stor del var hundars ställning som sällskapsdjur och deras närhet till människor och förmåga till kommunikation som drev deras engagemang för att sätta stopp för experiment på dem.513 Inom antivivisektionsrörelsen gjordes de agentiella snitten annorlunda, där hamnade inte hundar inom den del av spektrumet där de var avlivningsbara vid medicinska experiment.

\section{Hundar och igelkottar}

I Sverige skulle det dröja ett par decennier in på 1900-talet innan någon lag som reglerade djurexperiment kom till stånd, och därför kunde Borelius obehindrat genomföra egna djurförsök för att studera kastreringens påverkan på prostatan. Borelius resonerade också på ett annat sätt än de läkare och kirurger som valde hundar när han valde djur för sina experiment. Han menade att en mängd forskare hade genomfört djurexperiment under de föregående åren som hade visat att en normal prostata atrofierade efter kastrering. Men när det gällde kastrering för att bota prostatahypertrofi var dessa resultat av begränsad betydelse, enligt Borelius, för även om en normal prostata krympte efter kastrering hos både människor och djur "så är det för ingen del lika antagligt, att en patologiskt förändrad, en hypertrofisk prostata skulle på samma sätt påverkas". ${ }^{514}$ Borelius lyfte fram ett experiment som Félix Legueu hade genomfört på en äldre hund med en förstorad prostata. Prostatan hade dock även varit sklerotisk, alltså bestått av

513 Guerrini 2003, s. 75, 77.

514 Borelius 1897a, s. 280. 
förhårdnad vävnad, och kastreringen hade inte fått önskad effekt. Legueu menade att det berodde på sklerosen. ${ }^{515}$

Även om Borelius lyfte viss kritik mot vad dessa djurexperiment verkligen kunde säga om kastreringens påverkan på prostatahypertrofi betydde det inte att han såg dem som betydelselösa och han bestämde sig för att själv genomföra djurexperiment för att bidra till resultaten. De som tidigare hade experimenterat på djur för detta syfte hade nästan utan undantag använt sig av hundar, enligt Borelius, eftersom hundar har "en relativt stor, för palpation tillgänglig prostata". ${ }^{516}$ Borelius bestämde sig för att försöka hitta en bättre grupp djur att experimentera på. Efter anvisningar av den svenske zoologen Wilhelm Leche (1850-1927) och studier av den holländske zoologen Oudemans arbete Die accessor. Geschlechtsdrüsen der Säugethiere bestämde sig Borelius för djur tillhörande ordningen insektsätare, närmare bestämt igelkottar. ${ }^{517}$

En av anledningarna till valet av igelkottar var deras "synnerligen storartade accessoriska könskörtlar". ${ }^{518}$ Det fanns även andra fördelar med att välja igelkottar. Till exempel har män och hundar en prostata, men igelkotten har fler:

Igelkotten har prostata bestående af 4 särskilda körtlar med hvar sin utförsgång, ett inre par liggande inom bäckenet på den ventrala sidan af urinblåsan och ett yttre par, liggande på utsidan af os ischii, en på hvardera sida. ${ }^{519}$

För Borelius verkar valet av experimentdjur, och vilka djur han betraktade som möjliga experimentdjur, ha berott mer på vilka djur som hade en prostata som

\footnotetext{
515 Borelius 1897a, s. 280.

516 Ibid.

517 “Insektsätare” är en föråldrad benämning, idag räknas igelkottar till ordningen äkta insektsätare tillsammans med mullvadar, näbbmöss och snabelslidmöss.

518 Borelius 1897a, s. 281.

519 Ibid.
} 
var enkel att undersöka och som hade flera prostatakörtlar, än på vilka som hade en prostata som liknade en mans, vilka som kunde drabbas av prostatahypertrofi och vilka djur som var tillräckligt lika människor men inte för lika. Den del av spektrumet av djur som räknades som lämpliga "experimentdjur" hade för Borelius helt andra egenskaper och de agentiella snitt som han gjorde mellan människa och djur och experimentdjur såg annorlunda ut.

Även Griffiths hade valt igelkottar, och mullvadar, för sina experiment 1889 eftersom djur i ordningen insektsätare hade så tydliga cykliska perioder av sexuell aktivitet och inaktivitet vilket gjorde förändringarna i deras sexuella körtlar lätta att observera. Under största delen av året var prostatan mycket liten och befann sig i ett passivt stadium, men den växte till och fick sin sekretbildande funktion under brunsten. Det visade enligt Griffiths tydligt att prostatan hos dessa djur, och troligtvis hos alla däggdjur, var en helt sexuell körtel vars enda funktion var att bilda ett sekret som blandades med spermierna från testiklarna och sedan ejakulerades som en del av sädesvätskan. ${ }^{520}$

Resonemangen bakom valet av experimentdjur skilde sig åt beroende delvis på syftet med experimenten. Griffiths tidiga experiment på igelkottar och mullvadar gick ut på att undersöka skillnader mellan inaktiva och aktiva tillstånd hos könskörtlarna. Delvis skilde det sig också åt beroende på vad den som experimenterade ansåg att prostatan var (körtel eller muskel) och på vilka djur det tydligast gick att demonstrera påverkan av kastrering på prostatan. Vilka frågor som drev de läkare, anatomer och fysiologer som genomförde experimenten påverkade resultaten. Griffiths tidiga studier producerade kunskap om testiklarnas påverkan på prostatan, men syftet var inte att producera kunskap om hur kastrering påverkade prostatan vid prostatahypertrofi. Hans val av experimentdjur styrdes därför av vilka djur som tydligt genomgick en brunst och vilka djur han hade möjlighet att genomföra experiment på.

${ }^{520}$ Griffiths 1889b, s. $37-38$. 
När experimenten började syfta till att skapa kunskap om hur kastrering eller vasektomi påverkade prostatan vid prostatahypertrofi förändrades resonemangen om valet av experimentdjur. Vilka djur inom spektrumet avlivningsbara som passade berodde på hur lika människans deras testikel- och prostatafunktion bedömdes vara. För de flesta föll valet på hundar eftersom de enligt de agentiella snitt som gjorts var avlivningsbara, hade en sammanväxt prostata och kunde drabbas av prostatahypertrofi.

\section{Experimentens omfattning}

Därnäst behövde de som genomförde dessa experiment besluta sig för hur många djur som skulle ingå i experimenten för att de skulle ge några användbara resultat. De behövde också besluta sig för hur lång tid efter kastreringen eller vasektomin som djuren skulle avlivas och prostatan undersökas. Återigen verkar begränsningar ha gjort att tillgång och möjligheter fick styra. Joseph Griffiths kastrerade en hund som avlivades efter 21 dagar. ${ }^{521}$ Några år senare nämnde han detta som början på en serie djurexperiment som han hade genomfört på hundar i Paris och sedan i Cambridge; han tycks alltså ha fått tillstånd att genomföra experiment i England. Dessa experiment utgjordes huvudsakligen av två former av vasektomi som genomfördes på valpar och vuxna hundar. Griffiths uppger inte det totala antalet hundar, utan redovisar några försök mer noggrant och anger då hundarnas ålder och ras. ${ }^{522}$

Ramm kastrerade hundar innan han genomförde den första kastreringen av en man med prostatahypertrofi, men han anger inte hur många hundar han experimenterade på. ${ }^{523}$ White kastrerade 35 hundar som sedan avlivades vid olika tidpunkter för att han skulle kunna följa påverkan på prostatan efter

${ }^{521}$ Griffiths 1895a, s. 581.

${ }^{522}$ Griffiths 1895d, s. $917-920$.

${ }^{523}$ Ramm 1896, s. 30; Ramm 1895, s. 4. 
kastreringen. ${ }^{524}$ Hur många hundar fransmannen Pavone experimenterade på framgår inte heller, de nämns bara som en serie experiment. ${ }^{525}$

Det tycks alltså inte ha varit så viktigt att redovisa antalet experiment, men det fanns en föreställning om att flera experiment behövdes för att man skulle kunna uttala sig. Borelius hade i alla fall tänkt genomföra fler än vad som faktiskt blev av - det gick nämligen redan från början lite snett med hans experiment:

Det lyckades mig icke att ställa mer än 6 igelkottar till mitt förfogande och två af dessa föreföllo dessutom föga lifskraftiga. Denna omständighet och vidare att försöken utfördes under hösten, då igelkottens prostata och sädesblåsor normalt äro atrofierade eller åtminstone små och knapt hälften eller en tredjedel så små som under brunst-tiden, som infaller på våren och sommaren, gjorde, att resultaten af undersökningen blefvo magra. ${ }^{526}$

I en fotnot till detta tillade han:

Jag hade ämnat att under sommaren 1896 kunna fullfölja försöken på större antal igelkottar, som jag hoppats få från Ronneby, der förut funnits rikligt med dylika. Denna förhoppning slog emellertid fel. ${ }^{527}$

När Borelius inlett experimenten hittade han två av igelkottarna döda bara några dagar efter operationerna. De resterande fyra överlevde och avlivades mellan en månad och knappt tre månader senare. ${ }^{528}$

Borelius och andra läkare som utförde djurexperiment för att undersöka kastreringens och vasektomins påverkan på prostatan hade tagit till sig Bichats

${ }^{524}$ White 1893, s. $182-184$.

525 "An Epitome..." 1895c, s. 2.

${ }^{526}$ Borelius 1897a, s. 281.

527 Ibid.

${ }^{528}$ Ibid, s. $281-283$. 
uppmaning att upprepa samma experiment flera gånger, men tillgången på djur att experimentera på var avgörande för kunskapsproduktionen. Publiceringar i främst internationella tidskrifter gjorde att flera läkares, kirurgers, anatomers och fysiologers resultat kunde sammanställas, även om de individuellt inte hade genomfört tillräckligt många experiment för att skapa kunskap om kastreringens och vasektomins effekt på prostatahypertrofi.

Det fanns en tydlig materiell begränsning. Kunskapsproduktionen och skapandet av kastrering som en fungerande behandling mot prostatahypertrofi var beroende av materiella kroppar. För att stärka den semiotiskt-diskursiva hypotesen krävdes en intra-aktion mellan läkaren, apparaterna och experimentdjuren, samt ett tillräckligt stort antal djurkroppar som uppvisade de materiella förändringar som ansågs bevisa att kastrering var en fungerande metod för att minska prostatans storlek. Om lagstiftning satte stopp för djurexperiment, eller om det var svårt att få tag i ett större antal djur som dessutom överlevde ingreppet tillräckligt länge, så saknades en del av den bevisning som skulle få den vetenskapliga berättelsen att hålla och ge den legitimitet.

\section{Syftet med experimenten}

Dissektionerna och experimenten på djur syftade till att skapa kunskap dels om prostatans utveckling, dess struktur och vävnad och relation till omgivande organ och körtlar, dels om hur vasektomi och ensidig och dubbelsidig kastrering påverkade prostatan. Dessutom undersöktes huruvida prostatans storlek varierade med hur sexuellt aktivt djuret var, prostatans vikt i förhållande till testiklarna, mängden av muskulär- och körtelvävnad och den muskulära vävnadens koppling till det muskulära skiktet av urinblåsan. ${ }^{529}$

Ett syfte som växte fram ur kritiken mot kastrering var att undersöka möjligheterna att behandla prostatahypertrofi med vasektomi istället för

${ }^{529}$ MacMunn 1892, s. 328. 
kastrering. I början av året 1895 rapporterade White att han nu utförde experiment på hundar för att testa olika varianter av vasektomi - att knyta av eller kapa sädesledaren, blodkärlen och/eller nerverna i sädesledaren - för att orsaka atrofi av testiklarna som i sin tur fick prostatan att atrofiera. ${ }^{530}$ Kort därefter inledde han experiment på hundar för att även undersöka effekten av ensidig kastrering på prostatan. ${ }^{531}$ I maj samma år presenterade han sedan sina resultat inför American Surgical Association i New York och publicerade även föreläsningen i Annals of Surgery två månader senare..$^{532}$

Pavone experimenterade med avlägsnande av dels testiklarna, dels sädesledarna, och menade att dubbelsidigt avlägsnande av sädesledarna på hundar medförde samma atrofiering av prostatan som kastrering. De mikroskopiska undersökningarna visade samma förändringar i prostatan efter båda operationerna. Pavone rekommenderade därför avlägsnande av sädesledarna framför kastrering på människor eftersom det var en enklare operation som innebar en mindre stympning och en mindre risk för psykisk chock men samma goda behandlingsresultat. ${ }^{533}$

Borelius ville undersöka om ensidig kastrering eller vasektomi gav annorlunda resultat än dubbelsidig kastrering eller vasektomi, och även om kastrering gav annorlunda resultat än vasektomi. Av sina sex igelkottar kastrerade han två ensidigt (avlägsnade högra testikeln) och en dubbelsidigt samt kapade höger sädesledare på en, vänster på en och båda på en. ${ }^{534}$ Förutom sädesledarna skar han även av blodkärlen och nerverna i sädessträngen, vilket ströp blodtillförseln och nervimpulserna till testiklarna och medförde atrofi. Det

530 Willian White, "Castration for Prostatic Hypertophy", The British Medical Fournal, vol. 1, nr. 1782, feb. 23, 1895b, s. 448.

531 White 1895 c, s. 508.

532 White 1895 d, s. $46-57$.

533 "An Epitome..." 1895c, s. 2.

${ }^{534}$ Borelius 1897a, s. $282-283$. 
handlade alltså om att undersöka två olika sorters operationer, en där testiklarna avlägsnades direkt (kastrering) och en där sädesledarna kapades, knöts av eller avlägsnades (vasektomi) för att i nästa steg påverka testiklarna så att de atrofierade. Borelius följde åtminstone delvis Bichats uppmaningar: Han undersökte igelkottarna före experimenten och konstaterade att två av dem knappt var livsdugliga. Han noterade storleken på prostatan och de andra accessoriska könskörtlarna före experimentet för att kunna avgöra om storleken påverkades av kastreringen. På samma sätt undersöktes alla djur som användes vid experiment med kastrering. Det finns dock inga noteringar om att prostatan undersöktes efter kastrering medan djuret fortfarande var vid liv. Istället avlivades experimentdjur ofta vid olika tidpunkter efter kastreringen eller vasektomin för att studera hur tiden påverkade atrofieringen av prostatan.

De flesta djurexperiment som utfördes och som togs upp i debatten om kastrering och vasektomi som behandlingar mot prostatahypertrofi hade som syfte att klargöra dessa operationers påverkan på prostatan, och även till viss del hur testiklarna och sädesledarna påverkades av vasektomi. Tidigare experiment och dissektioner där testiklarna och prostatan varit av intresse, och som genomförts innan kastrering började diskuteras som behandlingsmetod, hade även syftat till att producera mer allmän kunskap om kroppen och de sexuella körtlarna.

Uttryckt på ett annat sätt så var syftet med experimenten att visa att experimentdjuren som ingick i spektrumet "möjliga experimentdjur" uppvisade de önskvärda effekterna och att dessa var överförbara på människor, vilket skulle legitimera kastrering eller vasektomi som en behandling mot prostatahypertrofi. De läkare och kirurger som utförde dessa experiment letade efter specifika effekter på prostatorna hos de avlivade djuren som gick att se i mikroskop eller med blotta ögat: att prostatan var mindre än före ingreppet eller vid mikroskopiska undersökningar uppvisade de strukturer som var förknippade med atrofi. 


\section{Resultaten av experimenten}

Vilka blev resultaten av dessa djurexperiment? De var något spretiga eftersom många av läkarna undersökte både kastrering och olika former av vasektomi samtidigt. Griffiths menade att när testiklarna avlägsnades hos fullvuxna djur atrofierade de accessoriska könskörtlarna (prostatan, sädesblåsorna och Cowpers körtlar) inom en så kort tid som tre månader. ${ }^{535}$ Han fann också att om sädesledarna knöts av eller skars av på hundar så påverkade det varken tillväxten av testiklarna hos unga hundar eller produktionen av spermier hos vuxna hundar. ${ }^{536}$

Efter att ha experimenterat på ett antal hundar, både valpar och vuxna djur, och jämfört resultaten med vilken effekt skador på delar i sädessträngen hade på mänskliga patienter konstaterade Griffiths att det verkade behövas något mer än en avknytning av sädesledaren för att orsaka strukturella förändringar i sädesledaren eller testiklarna. Hos hundarna hade avknytningen inte medfört någon förändring alls, och hos människor uppstod förändringar när en del av sädesledaren eller sädessträngen avlägsnades på grund av en cysta eller liknande. Griffiths antog att det innebar att blodkärl och nerver skadades eller kapades vid dessa ingrepp på människor vilket kunde få till följd att sädesledaren atrofierade eller att testiklarna påverkades. Förändringen hos testiklarna tillskrev Griffiths inte endast att dess sekretion skadades utan även att blodkärl och nerver skadades. ${ }^{537}$

535 Griffiths 1895b, s. 794.

${ }^{536}$ Griffiths 1893, s, 765. Samma resultat av vasektomi på djur rapporterades vid den större diskussion om operativa behandlingar för prostatahypertrofi som hölls vid Sixty-fourth Annual Meeting of the British Medical Association i Carlisle 1896. David MacEwan, Reginald Harrison, C. W. Mansell Moullin, Dr. Sandberg, John Chiene, F. A. Southam, Charles A. Morton, Jordan Lloyd, J. Haddon and J. H. Cameron, "Discussion On The Surgical Treatment Of Prostatic Hypertrophy", The British Medical fournal, vol. 2, nr. 1867, okt. 10, 1896, s. $989-996$.

${ }^{537}$ Griffiths 1895d, s. 920. 
Kastrering gav dock upphov till samma förändringar i hundars prostator som i människors. ${ }^{538}$ Efter kastrering av hundar och katter, och män, hade Griffiths noterat att prostatan krympte till en liten hård massa av fibrös bindväv efter ett år eller mer. ${ }^{539}$

När det gällde kastrering av djur var resultaten ganska okomplicerade: kastrering av ett vuxet djur medförde en atrofiering av prostatan och de övriga accessoriska könskörtlarna. När det gällde vasektomi var det dock annorlunda. Det var inte alla former av vasektomi som medförde en atrofiering av testiklarna och i förlängningen av prostatan. Här gjordes det agentiella snitt mellan olika strukturer i sädessträngen som skapade flera kunskapsobjekt (sädesledare, blodkärl, nerver och så vidare) och Griffiths konstaterade att det inte räckte att kapa eller knyta av sädesledaren. Genom att studera de olika strukturerna hos experimentdjuren efter att de avlivats hade han kommit fram till det krävdes att även nerver och blodkärl, eller bara nerver eller blodkärl, i sädessträngen kapades för att testiklarna skulle atrofiera.

Det viktiga för denna kunskapsproduktion var till stor del de agentiella snitt som tidigare gjorts. Precis som prostatan hade avskilts från kringliggande organ, körtlar och strukturer så hade sädessträngen delats upp i sädesledare, blodkärl och nerver, och att kapa dem visade sig ha olika påverkan på testiklarna.

White drog liknande slutsatser som bland andra Griffiths gjort av sina djurexperiment på hundar: att kastrering av hundar hade en tydlig och snabb påverkan på prostatan. Enligt de mikroskopiska undersökningar White gjorde var det först körtelvävnaden som atrofierade och sedan muskelvävnaden. Han upptäckte sedan att liknande observationer redan hade gjorts på hundar och hänvisade till två texter av Griffiths. ${ }^{540}$ Faulds menade att experiment flera år

${ }^{538}$ Griffiths 1895a, s. 581.

539 Griffiths 1889b, s. 39.

540 Nämligen Joesph Griffiths, "Observations on the anatomy of the prostate", Fournal of Anatomy and Physiology, vol. 23 (Pt3), april, 1889a; Griffiths 1889b; White 1893, s. 182 - 184. 
tidigare hade visat att prostatan atrofierade hos vissa djur efter kastrering, men dessa djur var unga och inte könsmogna. På grundval av det hävdade han att kastrering inte ledde till att prostatan krympte, varken helt eller delvis. ${ }^{541}$

Borelius resultat blev magra. Förutom att han endast hade fått tag i sex igelkottar, och två av dem hade dött inom ett par dagar efter operationen, så fanns det betydande individuella skillnader mellan prostatans vikt hos djuren. Vid ensidig vasektomi eller kastrering tycktes det finnas en tendens till mindre accessoriska könskörtlar på den sidan, men resultatet var inte konstant. Enligt Borelius skulle det behövas väldigt många igelkottar för att dra några slutsatser om prostatans vikt och storleksförändring. Han skrev till slut:

Af ovanstående försök kunna inga som helst slutsatser dragas, jag har anfört dem egentligen endast för att möjligen uppmuntra någon annan, som kan få tillfälle dertill, att fullfölja försöken på större material och vid för försöken lämpligare årstid. ${ }^{542}$

Vid Nordiska Kirurgiska Föreningens möte senare samma år uttryckte Maximus Widekind af Schultén en tro på att vidare klinisk forskning och experiment på djur skulle klargöra hur testikel- och vasektomioperationer påverkade prostatahypertrofi. ${ }^{543}$ Han hoppades att den stympande dubbelsidiga kastrationen snart skulle ersättas av en mindre operation. ${ }^{544}$

Ibland föll experimenten ut som förväntat men ibland inte: det materiella objektet som studerades uppvisade inte de förändringar som eftersträvades. Vasektomi, eller vasektomiliknande händelser som olyckor där sädesledaren gått av, hade innan många av dessa experiment genomfördes medfört att testiklarna

\footnotetext{
${ }^{541}$ Faulds 1895, s. 975.

542 "Nordiska kirurgiska föreningens tredje..." 1897, s. $282-283$.

543 Ibid, s. 391.

544 Ibid, s. 392.
} 
atrofierade och att prostatan krympte till följd av det. Vid experimenten visade det sig dock att detta inte alltid inträffade.

Det påverkade hur läkare såg på ingreppet och fick till exempel Griffiths att prova andra varianter av vasektomi. När andra strukturer, som blodkärl eller nerver, skars av uppnåddes det önskade resultatet. Kunskapen att det förhöll sig så producerades i intra-aktion mellan Griffiths, de instrument han använde, de strukturer som han ansåg ingick i sädessträngen och den effekt ingreppen fick på experimentdjuren. När ett ingrepp inte gav det eftersträvade resultatet, när det materiella gjorde motstånd mot det diskursivt förväntade, påverkade det Griffiths agerande. För att uppnå andra resultat provade han att skära av andra strukturer, vilket gav andra effekter på kringliggande strukturer så som testiklarna och prostatan.

\section{Andra kunskaper om prostatan}

Det var inte bara effekterna av kastrering och vasektomi som undersöktes vid djurexperimenten. Det fanns även ett intresse av att vidare utforska prostatans funktion och roll som sexuell körtel. Redan innan White och Ramm 1893 föreslog kastrering som en behandling mot prostatahypertrofi utfördes många djurexperiment och dissektioner för att utröna prostatans funktion.

MacMunn hade dissekerat många djurarter och rapporterade några av sina resultat 1892. Han var intresserad av huruvida djur som var mer sexuellt aktiva hade en större prostata, men lyckades inte finns någon sådan korrelation. Beträffande förhållandet mellan prostatans och testiklarnas vikt fann han att det bara var hos knubbsälen som vikten hos prostatan och testiklarna var lika. Han intresserade sig även för förhållandet mellan mängden körtelvävnad och mängden muskelvävnad i olika djurs prostator. Förutom hos knubbsälen, som hade en stor mängd muskulär vävnad i prostatan, bestod de prostator han undersökte till övervägande delen av körtelvävnad. Vildsvinets prostata beskrev han som 
"entirely racemose, very succulent, and with little or no muscular elements". ${ }^{445}$ MacMunn konstaterade att prostatamuskulaturen hos män var mycket intimare kopplad till urinblåsan än hos något av de djur han undersökt. ${ }^{546}$

MacMunn drog slutsatsen att prostatan främst var en sexuell körtel, vilket framgått av hans egna och andras undersökningar av prostatan hos lägre djur och vilket också Hunters observationer av kastreringens effekt på prostatan pekade mot. MacMunn menade dock att det intima förhållandet mellan prostatamuskulaturen och urinblåsan hos människan antydde en underordnad funktion som hade med urineringen att göra. ${ }^{547}$

Griffiths, som studerat eunucker och män som på olika sätt avvek från normen att ha två fullt fungerande testiklar, menade att de övriga sexuella körtlarna var lika outvecklade hos eunucker som hos kastrerade djur som hundar, katter, hästar, oxar, och svin. Speciellt hos svin var skillnaden i storlek hos prostatan och Cowpers körtel mellan kastrerade och okastrerade djur markant. Denna skillnad visade tydligt att testiklarna utövade en ytterst viktig påverkan på utvecklingen av dessa körtlar, enligt Griffiths. ${ }^{548}$

Studierna av djur bidrog också till diskussionen om kastreringens påverkan på psyket. Griffiths konstaterade att det fanns för lite information om kastreringens påverkan på psykets utveckling, men påpekade: "I need scarcely allude to the difference between the gelding and the entire horse, and between the bullock and the bull, to indicate the effect of removal of the testes upon the body." Hos andra djur, som katten, var dessa skillnader inte lika markanta. ${ }^{549}$ Prostatan hos djur fortsatte att intressera läkare och anatomer, inte bara i relation till kastrering och

545 MacMunn 1892, s. 328.

546 Ibid.

547 Ibid.

548 Griffiths 1895b, s. 793 - 794. Se även Henry Morris, “An address On The Study Of Anatomy”, The British Medical fournal, vol. 2, nr. 1822, nov. 30, 1895, s. 1338.

${ }^{549}$ Griffiths 1895b, s. 794. 
vasektomi som behandlingsmetoder mot prostatahypertrofi utan för att nå kunskap om den mänskliga prostatan. Spektrumet "experimentdjur" fyllde en funktion som "nästan mänsklig" när det gällde att studera andra funktioner eller annan påverkan på prostatan hos människor.

\section{Djurexperimentens betydelse för kastrering som behandlings - metod}

Praktiken att kastrera patienter som led av prostatahypertrofi kan beskrivas som ett enda stort experiment som involverade läkare från bland annat Sverige, Norge, Danmark, Storbritannien, Frankrike, Tyskland, USA och Kanada. En hypotes presenterades baserad på teoretiska antaganden om kroppen, djurexperiment samt kliniska erfarenheter av patienter som hade kastrerats av någon annan orsak eller som saknade testiklar eller hade icke-fungerande testiklar. Mansell Moullin skrev 1896 att "a sufficient number of operations have been performed upon men to make the experiment (for such, of course, it is) justifiable". ${ }^{550}$ Det är intressant uttryckt: han hävdade att det stora antalet redan genomförda operationer var det som rättfärdigade experimenten på människor med kastrering för att bota prostatahypertrofi, och han betecknade uttryckligen operationerna på människor som experiment.

Magendies och Bernards inställning att djurexperiment skulle föregå experiment på människor medförde inte att experiment på människor var uteslutna. Det hade gjorts ett antal experiment på djur innan den första människan kastrerades för prostatahypertrofi, men en stor del av dem genomfördes parallellt med att människor kastrerades på denna indikation. Experimenten på människor visar att de agentiella snitten mellan djur och människor inte uteslöt människor från att bli experimenterade på. Det spektrum

${ }_{550}$ Mansell Moullin 1896c, s. 350. 
som gjorde människor och alltför människoliknande djur, som primater, omöjliga att experimentera på var otydligt, liksom gränsen mellan experiment och behandlingar. Det var inte möjligt att uttryckligen experimentera på människor, men i praktiken genomfördes ingrepp som enligt vissa läkare och kirurger inte skilde sig speciellt mycket från regelrätta experiment.

Det är svårt att avgöra hur stor andel av de läkare som kastrerade patienter för prostatahypertrofi som presenterade sina resultat i medicinska tidskrifter, men de statistiska sammanställningar som gjordes och publicerades omfattade hundratals patienter. Det var som ett kliniskt experiment som pågick under flera år då läkare och kirurger prövade metoden på patienter utan att vara säkra på utkomsten. Resultaten som rapporterades in diskuterades och vissa stödde hypotesen, andra inte. Processen var naturligtvis inte så tydlig i sina stadier, många av de teorier om kroppen som styrde processen utvecklades och förändrades under tiden som kastrering och vasektomi användes. På samma sätt utfördes många av djurexperimenten och studierna av "avvikande män” under tiden som kastrering faktiskt utfördes på patienter med prostatahypertrofi.

Djurexperimenten presenterades som en integrerad del av den medicinska kunskapsproduktionen. I artiklar och föredrag flöt texten mellan teoretiska resonemang, kliniska beskrivningar och djurexperiment, och alla delar fyllde en funktion i konstruktionen av kunskap och kunskapsobjekt. Den vetenskapliga berättelsen som läkare berättade om prostatahypertrofi, kastrering, vasektomi och hur det manliga urogenitala systemet fungerade vilade på några kunskapsproducerande grundpelare: jämförelser med den kvinnliga kroppen, jämförelser med avvikande manliga kroppar, djurexperiment samt klinisk erfarenhet. Tillsammans gjorde dessa att prostatahypertrofi kunde behandlas med kastrering, eller vasektomi.

Några moraliska eller etiska eller invändningar mot djurförsöken hördes inte - den ende som uttryckte kritik var Harrison, som menade att det inte fanns någon likhet mellan det som kunde drabba hundar och den prostatahypertrofi som 
drabbade män. ${ }^{551}$ Han var inte emot djurexperiment i sig, men han betonade hur mycket prostatan skilde sig mellan människor och djur och hur annorlunda fyrfota djurs hållning var. Harrison menade att människans upprätta position skapade ett tryck nedåt så att prostatan behövdes som ett muskulärt stöd för urinblåsan och hade en slutande funktion. Urinläckage hos äldre förklarade han delvis med att prostatans muskulatur förslappades med åldern och inte längre kunde hålla tätt, och förslappningen kom sig av att män höll sig för länge. Det gjorde djurexperiment mer eller mindre värdelösa eftersom de fyrfota djurens prostata fyllde en delvis annorlunda funktion och de inte drabbades av prostatahypertrofi på ett liknande sätt som människor. ${ }^{552}$ Framförallt stämde inte andra läkares resultat och resonemang kring djurförsöken och påverkan på prostatan med Harrisons grundidé om vad prostatan var och hur den fungerade. För Harrison innefattade inte gruppen "möjliga experimentdjur" samma djur. Olika djurs prostata kunde inte fungera som en "nästan som" och ge kunskaper som kunde överföras till människor. ${ }^{553}$

Det finns inget i materialet som tyder på att Harrison använde sig av annorlunda teknologiska hjälpmedel jämfört med sina samtida kollegor, men hans intra-aktion med prostatan hos människor och djur gestaltade sig annorlunda. Harrison hade en avvikande diskursiv förklaring till prostatans funktion och den hypertrofierade prostatans orsaker, vilken hade vuxit fram under hans studier av prostatan då han tolkat strukturer och olika funktioner annorlunda. Som Barad påpekat är inte alla förklaringar av hur världen fungerar lika bra. ${ }^{554} \mathrm{Jag}$ har tidigare nämnt att Harrisons förklaringar av den mänskliga prostatans funktion och prostatahypertrofins orsaker till slut fick ge vika för att ett alltför stort motstånd

${ }^{551}$ Harrison 1895, s. 1605.

552 Harrison 1895, s. 1606 - 1607; Harrison 1896b, 474.

${ }^{553}$ En mer detaljerad genomgång av Harrisons syn på prostatan och prostatahypertrofi finns i kapitlet "Prostatan, prostatahypertrofi och dess etiologi".

554 Barad 2007, s. $206-207$. 
från den materiella världen. Detsamma gällde hans förklaringar till varför prostatan hos hundar skulle fungera så annorlunda än människans.

Hela medicinvetenskapen förändrades under 1800-talet, såväl organisationen av utbildningen och sjukhusen som utvecklingen av instrument och operationsmetoder. Denna utveckling ledde dock inte alltid till att hänsyn togs till patientens rättigheter. ${ }^{55}$ Vad kastrering beträffar är det dock väldokumenterat i det svenska och internationella materialet att ingreppet krävde patienternas godkännande, och i vissa fall noteras att ingreppet inte utfördes trots läkarens rekommendation. ${ }^{556}$ Det kunde även förekomma att läkare vägrade att utföra ingreppet, som när Reginald Harrison vägrade att kastrera en patient med prostatahypertrofi trots att patienten insisterade. ${ }^{557}$

Rutiner för patientgodkännande och etiska och moraliska regler har vuxit fram gradvis och det finns inget tydligt brott mellan innan och efter att det infördes. ${ }^{558}$ Vissa moraliska och etiska problem har diskuterats sedan antiken, såsom vivisektion av djur och människor, men samtidigt utfördes experiment och invasiva ingrepp på människor långt in på 1900-talet. ${ }^{559} \mathrm{Vad}$ som förenar de senare experimenten är ofta att de utförts på människor som tillhört andra grupper än vita män: kvinnor, rasifierade, funktionsnedsatta och ibland barn. ${ }^{560}$ De patienter som figurerar i mitt material är dock vita män utan funktionsnedsättning, och de hade redan under 1890-talet möjlighet att neka oönskade ingrepp.

${ }^{555}$ Franco 2013, s. 246.

556 Se till exempel Borelius 1896; Borelius 1897b, s. 598; “An Epitome...” 1985b, s. 26; F.

Fremont-Smith 1894, s. $52-55$.

${ }^{557}$ Harrison 1893, s. $708-709$.

558 Dyck \& Stewart 2016, s. 8.

559 Susan E. Lederer, Subjected to Science: Human Experimentation in America Before the Second World War, Baltimore: Johns Hopkins University Press, 1995.

${ }^{560}$ Dyck \& Stewart 2016, s. 215 - 239, 240 - 259, 260 - 280; Bommenel 2006; Reverby 2009. 
I den vetenskapliga berättelsen om djurexperimenten framställdes djur, speciellt hundar, som lika människor och möjliga att använda för att testa ingrepp som var tänkta för människor. Både White och Ramm genomförde djurexperiment innan de kastrerade sin första patient. De sökte även i djurexperimentens historia för att finns stöd för sina resultat i vad tidigare läkare, kirurger, anatomer och fysiologer kommit fram till när det gällde kastrering. De flesta experimenten genomfördes dock parallellt med att patienter kastrerades. Det går därför inte att säga att det fanns en tydlig fas av djurexperiment som följdes av en fas med experiment på människor. Däremot skymtar Magendie och Bernards åsikt att djurexperiment borde föregå experiment på människor bakom agerandet vid införandet av kastrering som behandlingsmetod. Både White och Ramm var måna om att framhålla att framgångsrika djurexperiment hade utförts innan patienter hade kastrerats, även om tiden mellan dessa var kort, i synnerhet för Ramm. Han kastrerade den första hunden den 25 januari 1893 och sin första patient den 3 april samma år. Denna patient visades sedan upp den 12 april för det medicinska sällskapet i Kristiania samtidigt som Ramm redogjorde för sina djurexperiment och de teoretiska resonemang som låg bakom kastrering som behandlingsmetod för prostatahypertrofi. ${ }^{561}$

Den vetenskapliga berättelse som behövdes för att legitimera djurexperimenten med kastrering och vasektomi såg annorlunda ut beroende på hur läkaren eller fysiologen resonerade. De flesta valde ett djur som många ansåg kunde drabbas av prostatahypertrofi, alltså hundar. Borelius resonerade annorlunda: han valde ett djur där det fanns en markant skillnad i könskörtlarna mellan det inaktiva tillståndet och brunsten och där han bedömde att körtlarna var tydliga och inte sammanväxta. Detta borde bidra till tydliga resultat - tvärt emot dem som ansåg att den mer övertygande berättelsen vilade på att

561 Ramm 1896, s. 30. 
experimentdjurets prostata var så lik människans som möjligt - alltså en sammanväxt körtel.

Det framgår inte alltid i hur stor utsträckning experimenten omfattade jämförelser med "normala" djur. I vissa fall beskrevs vilken storlek och struktur hos prostatan som var normal för arten. Beträffande flera av de arter som användes fanns det en hel del tidigare observationer och uträkningar av en medelstorlek på prostatan. Däremot verkar det som att experimentdjurets prostata alltid undersöktes före ingreppet för att kunna jämföra storleken före och efter. Denna del av experimenten beskrivs inte särskilt utförligt, men de läkare som experimenterade förefaller till stor del ha följt Bichats uppmaning att undersöka "normala" djur som kontrolldjur. Det syns i bedömningar som att djuret före kastreringen hade en normalstor prostata.

Det som behövdes för att kunna genomföra dessa djurexperiment och dra slutsatser av dem som gällde även för människor kan förklaras med att människor och olika djur placerades på ett spektrum. Det handlade om att dels förhålla sig till det spektrum av avlivningsbarhet som redan skapats genom lagar och riktlinjer, och dels om att skapa ett spektrum av "möjliga experimentdjur". Experimentdjuren behövde vara tillräckligt lika människor för att resultaten skulle anses överförbara, till exempel skulle de (oftast) ha en sammanvuxen prostata som liknade människans. För att vara avlivningsbara fick de å andra sidan inte vara för lika människor. Primater undveks eftersom de fysiologiskt liknade människor på så många sätt. Andra djur skyddades av lagen, och framförallt fanns det regler som begränsade vilken sorts experiment man fick utföra, exempelvis var vivisektion av vissa djur inte tillåten. 


\section{Kastrering av kvinnor och män}

Kunskapsproduktionen kring kastrering som ett möjligt botemedel mot prostatahypertrofi vilade till stor del på jämförelser med andra kroppar än den normala manskroppen: med kvinnor och uterusmyom, med avvikande män och med djur. Dessa jämförelser hade sina förespråkare och sina kritiker men de fyllde alla en funktion i produktionen av prostatahypertrofi som en sjukdom och diagnos och av kastrering som ett möjligt botemedel. I det här kapitlet tittar jag närmare på ett av de områden som väckte mest kritik mot kastrering som behandlingsmetod: de oönskade psykiska och även fysiska effekter som vissa läkare och kirurger oroade sig för att kastrering kunde ge.

Hos män som hade kastrerats för att behandla prostatahypertrofi hade man observerat dels symptom som uppstod direkt efter operationen, dels mer långsiktiga förändringar av deras fysiologi. De symptom som uppstod direkt efter operationen kunde vara både övergående och permanenta psykiska tillstånd vilka i ett fåtal fall ledde till patientens död. Mer långsiktigt påverkades bland annat vikten samt den sexuella lusten och förmågan, och det fanns en oro för att kastreringen kunde påverka männens allmäntillstånd och försvaga dem.

I detta kapitel använder jag mig i större utsträckning än i tidigare kapitel av tidigare studier om kastrering av kvinnor (ovariektomi) kring sekelskiftet för att jämföra synen på kvinnlig och manlig kastrering. 562

562 Ovariotomi avser avlägsnandet av sjuka ovarier. Kastrering, eller det som av vissa kallades den "normala ovariotomin", avser avlägsnandet av friska ovarier. Vissa av de läkare som avlägsnade friska ovarier menade att dessa var sjuka, men att det inte var en sjuklighet som gick att observera som cystor och liknande, utan snarare ett fel i funktionen. Detta 


\section{Kvinnlig kastrering och ovariotomi}

Idén att kastrera män med prostatahypertrofi kom från praktiken att kastrera kvinnor med uterusmyom. Men hur hade den kvinnliga kastreringen inom medicinen sett ut fram till 1890-talet? John Hunter var en av de kirurger som redan under 1700-talet föreslog ovariotomi som en radikal metod för att behandla cystor på ovarierna. Han såg vid denna tid inget problem med att operera bort ovarierna på kvinnor, han menade att "there was no reason why women should not bear 'spaying' as well as other animals did". ${ }^{563}$ Samtidigt var dödligheten vid ovariektomi så hög att operationen endast genomfördes enstaka gånger under 1700-talet. Enligt Moscucci genomfördes den första ovariektomin 1809 av den amerikanske kirurgen Ephraim McDowell (1771-1830), och patienten överlevde. Ingreppet utfördes utan bedövning eller nedsövning. ${ }^{564}$ I Sverige genomfördes en ovariotomi 1812, men patienten avled. ${ }^{565}$ Dödligheten fortsatte att vara hög och ovariektomier utfördes inte i någon större utsträckning förrän efter 1838, när en lyckad ovariektomi återuppväckte intresset för operationen. ${ }^{566}$ Antalet patienter som dog av operationen fortsatte dock att vara högt, 44,5 procent enligt en sammanställning av 200 fall från 1855. ${ }^{567}$

Siffrorna utlöste en hetsig debatt där stark kritik riktades mot ingreppet, både på grund av den höga mortaliteten och eftersom ingreppet i Frankrike, England och Sverige liknades vid en vivisektion. ${ }^{568}$ Utan anestesi och antiseptik eller aseptik var dessa operationer plågsamma och mycket farliga för patienten.

resonemang återkommer längre fram i kapitlet. Jag kommer att för enkelhetens skull referera till avlägsnandet av sjuka ovarier som ovariotomi och friska ovarier som kvinnlig kastrering.

563 Moscucci 1990, s. 135.

564 Ibid, s. $135-136$.

${ }^{565}$ Johannisson 1995, s. 189.

566 Moscucci 1990, s. 137.

${ }^{567}$ Johannisson 1995, s. 189; Moscucci 1990, s. 137.

${ }^{568}$ Johannisson 1995, s. 190; Frampton 2018, s. 3. 
Ovariotomi fortsatte att kritiseras hårt i mitten av 1800-talet, men när förutsättningarna för lyckad bukkirurgi förbättrades under andra delen av 1800talet, i och med möjligheten att söva patienten och den allt mindre risken för infektioner som antiseptiken och aseptiken innebar, ökade intresset för ovariektomin. Allt fler läkare utförde ovariektomier och en del av kritiken tystnade. Från att ha varit en operation som främst användes mot cystor på ovarierna, svulster, inflammationer och menstruationsstörningar började nu operationen användas mot fler sjukdomar, bland dem uterusmyom. Det var under 1870-talet och 1880-talet indikationerna för ovariotomi utökades till sjukdomar där själva ovarierna inte var sjuka, som bland andra dysmenhorré (menstrautionsrubbningar), menstruell epilepsi, "hysteri", neurasteni, nymfomani och sinnessjukdomar. ${ }^{569}$ De förändrade indikationerna medförde också en förändring i vad operationerna kallades. När ovarierna inte var sjuka kallades ingreppet "normal ovariektomi" eller "Battey's operation" och introducerades under 1872 av tre läkare oberoende av varandra: Robert Battey (amerikansk kirurg), Alfred Hegar (tysk gynekolog) och Lawson Tait (brittisk gynekolog). 570

När operationen började användas för bland annat uterusmyom hade alltså något hänt. Ett ingrepp som från början använts för att avlägsna sjuka ovarier användes nu för att avlägsna "friska" ovarier, alltså kastrering, för att de ansågs orsaka sjukdomar i andra delar av kroppen. Många av de läkare som genomförde dessa "normala ovariektomier" hävdade dock att ovarierna hos dessa patienter var sjuka. ${ }^{571}$ Ovariektomi och kvinnlig kastrering (normal ovariotomi) var omdebatterat och hårt kritiserat från vissa håll medan andra menade att de var gynekologins främsta triumf. ${ }^{572}$

\footnotetext{
${ }^{569}$ Moscucci 1990, s. 156 - 157; Johannison 1995, s. 189, $194-195$.

570 Sengoopta, 2006, s. 15; Nilsson 2003, s. 149; Moscucci 1990, s. 157

571 Moscucci 1990, s. 157.

${ }^{572}$ Moscucci 1990, s. 134, 157 - 160; Johannisson 1995, s. 195 - 197.
} 
Under 1870- och 1880-talet spred sig alltså ingreppet allt mer och Hegar använde kvinnlig kastrering för att behandla, utöver de indikationer som nämnts, bland annat underlivssmärtor, och nervsmärtor. Under 1880-talet började amerikanska läkare kastrera kvinnor med psykiatriska diagnoser, framförallt ansågs mani och psykos ha sitt ursprung i ovarierna. ${ }^{573}$ I Sverige var indikationerna färre för kvinnlig kastrering enligt Ulrika Nilsson, som menar att de oftast utfördes vid svåra menstruationsblödningar och vid svåra blödningar till följd av livmodertumörer. ${ }^{574}$

Enligt Karin Johannisson var det ur glidningen från somatiska indikationer mot neurologiska och psykiatriska som kastreringen av kvinnor lanserades, definierat som att avlägsna friska äggstockar för att bota sjukdomar i nervsystemet. Den vanligaste anledningen att kastrera en kvinna var att hon led av "menstruell hysteri”, hysteri som på något sätt kunde associeras med menstruationen eller underlivet. ${ }^{575}$ Kvinnlig kastrering fortsatte att användas under 1890-talet. Mortaliteten var fortfarande hög, och det, samt oron för att ingreppet kunde leda till maskulinisering och förlust av sexuella känslor, väckte kritik från läkare, feminister och anti-vivisektionister. ${ }^{576}$

\section{Manlig kastrering}

Män hade kastrerats under tusentals år: av religiösa skäl, av kulturella skäl, som straff och för att behandla sjukdomar i testiklarna. ${ }^{577}$ Manlig kastrering av medicinska skäl förekom aldrig i samma utsträckning som kvinnlig kastrering, men det var inte alls så ovanligt som Laqueur påstod när han skrev: "There was

${ }^{573}$ Johannisson 1995, s. 195.

574 Nilsson 2003, s. 150.

575 Johannisson 1995, s. 194.

${ }^{576}$ Moscucci 1990, s. $157-160$.

577 Reusch 2013, s. $12-14$. 
no male castration, no removal of healthy testes, except in a few rare and quite specific instances of criminal insanity or to treat cancer of the prostate." ${ }^{578}$ Edward Shorter har frågat sig varför det inte genomfördes lika många manliga kastreringar som kvinnliga och hävdar att "[m]ale surgeons, though driven by reflex theory, probably shrank back psychially from mutilating patients of their own gender in a way they were perfectly willing to do to women". ${ }^{579}$ Män hade kastrerats för att bota epilepsi och spermatorré eller för att förhindra onani, men i mycket mindre utsträckning. ${ }^{580}$

I slutet av 1800-talet diskuterades manlig kastrering allt mer som ett straff för kriminella och sexualförbrytare, men även för att både bota vansinniga eller svagsinta eller förhindra att de fortplantade sig. ${ }^{581}$ Inom eugeniken övergavs dock snabbt idén om kastrering, och istället kapades eller blockerades äggledarna eller sädesledarna. ${ }^{582}$ Kastrering diskuterades och användes också för att hindra människor som kategoriserades som hermafroditer från att känna erotisk attraktion eller fortplanta sig, men även för att "bota" homosexualitet. 583

Den kvinnliga kastreringen har alltså en mycket kortare historia än den manliga, helt enkelt för att den bukkirurgi som krävdes för att avlägsna ovarierna inte kunde genomföras förrän i mitten av 1800-talet utan att de flesta patienter dog. Hos män är det kirurgiska ingreppet däremot relativt enkelt och ofarligt. Eftersom det var en etablerad teknik under min undersökningsperiod finns det mycket lite diskussion i materialet om hur det gick till. En av de få beskrivningarna av en kastrering publicerades 1895 i British Medical fournal av James Swain, assisterade kirurg vid Bristol Royal Infirmary, som beskrev hur han gick till väga:

\footnotetext{
578 Laqueur 1992, s. 176.

579 Shorter 1992, s. 93.

${ }^{580}$ Darby 2005a, s. 140, 8; Darby 2005b, s. 286, 300.

${ }^{581}$ Dale 2010, s. 39, $46-48,53$.

582 Bryant 2012, s. 239.

583 Matta 2005, s. $79-80$.
} 
The method of operation I adopted was to make a median cut with scissors along the lowest portion of the raphé of the scrotum, when the testicles were easily turned out from either side; and I can strongly recommend this procedure for the rapidity and facility with which it is accomplished, and for the small amount of incision and suture required. ${ }^{584}$

Att döma av det fătal rapporter som finns om detta läkte snittet i regel utan komplikationer. Mansell Moullin föredrog dock att lägga snittet över den yttre ringen på ljumskkanalen, alltså där ljumskkanalen mynnade ut i pungen, eftersom han menade att det då var mycket lättare att hålla såret antiseptiskt. ${ }^{585}$

Problemen med kastrering var alltså inte själva det kirurgiska ingreppet. Frågan som läkare och kirurger ställde sig innan behandlingsmetoden började användas för prostatahypertrofi, och sedan allt mer, var hur kastrering påverkade kroppen och psyket. Var det verkligen helt oproblematiskt att avlägsna vuxna individers testiklar eller ovarier? Det var redan klargjort vilka stora effekter kastrering fick på utvecklingen om det gjordes prepubertalt, och erfarenheter av domesticerade djur pekade på en beteendeförändring hos hingstar, tjurar och andra handjur som kastrerats. Borelius skrev 1897, fyra år efter att behandlingsmetoden föreslagits och börjat användas allt mer:

Frånsedt de mer direkta och lätt förklarliga biverkningarna af kastrationen (bortfallande af potentia generandi och väl i regel inom kort äfven af potentia coeundi), så har man trott sig finna vissa specifika biverkningar, som skulle följa med borttagande af testis och yttra sig uti nedsättning i den fysiska och psykiska kraften. Härvidlag befinna vi oss på ett outforskadt område, och man kan väl tillägga, på ett svårutforskadt område. ${ }^{586}$

\footnotetext{
584 Swain 1895, s. 13.

585 "Reviews..." 1899, s. 1304.

586 Borelius 1897b, s. 642.
} 
De direkta och mer lättförklarliga biverkningarna Borelius talade om var oförmåga att befrukta, eftersom inga spermier längre producerades, samt oförmåga att genomföra penetrerande samlag. Utöver detta var det svårt att avgöra hur påverkan såg ut, men ett antal läkare och kirurger hade ändå åsikter om saken. En del av läkarna och kirurgerna som deltog i kastreringsdebatten var dock främst bekymrade över påverkan på psyket.

\section{Påverkan på det manliga psyket}

Under 1895 dyker det upp ett nytt ämne i mitt material: rapporter om en direkt och akut psykisk påverkan efter kastreringen. Denna negativa psykiska påverkan kopplades också till det som vagt kallades en negativ påverkan på allmäntillståndet. Den svenske kirurgen John Rissler menade i slutet av 1896 att denna fråga var "säkerligen den viktigaste, men också mest svårlösta af dem alla" ${ }^{587}$ Vidare hävdade han att hela kastreringens vara eller icke vara som behandling mot prostatahypertrofi hängde på hur frågan besvarades. Det spelade ingen roll hur positivt de lokala symptomen påverkades om ingreppet hade en negativ inverkan på patienternas allmäntillstånd. ${ }^{588}$

De mer akuta och märkbara tillstånd som drabbade några patienter kallades ofta "akut mani". Vad det innebar i detta sammanhang är svårdefinierat eftersom begreppet inte definieras i materialet, men de drabbade beskrevs som till exempel förvirrade, aggressiva, barnsliga, melankoliska, dementa och lidande av vanföreställningar. ${ }^{589}$ Borelius använde ibland ordet "psykos" istället för "akut mani”. De beskrivna tillstånden överlappar till stor del med de symptom som idag

\footnotetext{
${ }^{587}$ Rissler 1896, s. 670.

588 Ibid.

${ }^{589}$ Faulds 1895, s. 975; Borelius 1987b, s. 629; Borelius 1897d, s. 14; "Kidderminster Medical Society", The Lancet, vol. 145, nr. 3731 (ursprungligen publicerad som volym 1, nr. 3731) mars 2, 1895, s. 549 - 551; Clarke 1895, s. 563; Cabot 1896, s. 271 - 274.
} 
ingår i diagnosen "akut psykos", något som kan uppstå till exempel vid feber, sepsis och uremi och efter användning av narkosläkemedel - varav allt stämmer in på många av de kastrerade patienterna. 590

Borelius beskrev en av de patienter som han kastrerade på Karlskrona lasarett 1896 på följande sätt:

På de senare två dagarne har inträdt en påfallande förändring i pat:s allmäntillstånd. Under det har förut var liflig och intelligent, ser han nu virrig och stupid ut, svarar icke på tilltal; vill icke äta; är orolig och ligger ej stilla i sängen på natten utan irrar omkring i rummet då han släppes. Då han står upprätt, darrar han och skakar i hela kroppen. Han magrar af och gör intryck af den djupaste fysiska och psykiska depression [...] Har i natt varit lite lugnare, men vill icke ligga stilla i sängen utan vill springa omkring i skjortan. Då man tillsäger honom att gå i säng och ligga stilla, skrattar han fånigt. ${ }^{591}$

Denna patient tillfrisknade och skrevs ut tretton dagar efter insjuknandet, fullt frisk. ${ }^{592}$ Hos en 77-årig som hade kastrerats läkte såren utan komplikationer, men han blev förvirrad:

After the operation for about ten days the old gentleman's mind was somewhat peculiar. He did not believe himself at home, and did not know his relatives who were nursing him, trying at times to be violent, and I almost thought I was going to see one of those cases we hear so much about, namely, insanity following this operation. He fancied strange people were in the room, and heard strange voices talking to him. Happily this speedily passed away and has given him no further trouble. ${ }^{593}$

590 Akut psykos http:/ / www.lakartidningen.se/Klinik-och-vetenskap/MedicinensABC/2013/04/ABC-om -Akut-psykos/[sidan besökt 2019-10-05]

591 Borelius 1897b, s. 599.

592 Ibid, s. 600.

593 Charlton 1896, s. 1032. 
Ytterligare en annan patient rapporterades ha drabbats av vanföreställningar, blivit besvärlig och kissat i sängen. Tillståndet förbättrades dock efter ungefär tio dagar. ${ }^{594}$

Alla patienter som drabbades av dessa tillstånd tillfrisknade inte. I British Medical fournal rapporterade Henry E Clark att av fyra nyligen kastrerade patienter hade två dött av hastigt uppkommen akut mani och en av stroke. ${ }^{595}$ Borelius nämner också att tre patienter ska ha avlidit till följd av akut mani. ${ }^{596}$ Den brittiske kirurgen A G Faulds ifrågasatte i British Medical Fournal 1895 varför så få av de misslyckade kastrationerna rapporterades i detalj, och redogjorde sedan för sju fall där kastreringen misslyckats med att bota prostatahypertrofi och där fem av patienterna hade avlidit efter att ha uppvisat olika former av akut mani eller sinnessjukdom. ${ }^{597}$ Åsikterna gick isär: En del läkare och kirurger hävdade att det var själva kastreringen som orsakat mani och demens hos dessa patienter, och dessutom att ovariektomier och kastrering rapporterats ha utlöst mani hos kvinnliga patienter, speciellt om de haft en störd njurfunktion. Därför borde man inte kastrera män med prostatahypertrofi. ${ }^{598}$ Andra höll inte med om att det var själva kastreringen som var orsaken till negativ psykisk påverkan hos patienterna. Rissler diskuterade frågan 1896 i Hygiea och förhöll sig tveksam till det orsakssammanhang som beskrevs av vissa läkare och kirurger: "Man befinner sig här på ett område så outforskadt, att anförda skäl och motskäl knappast höja sig öfver de rent personliga meningarnas och tyckenas nivå." ${ }^{599}$ Själv menade han att om kastrering hade en så negativ inverkan på allmäntillståndet och psyket så

\footnotetext{
594 "Kidderminster Medical Society", The Lancet, vol. 145, nr. 3731 (ursprungligen publicerad som volym 1, nr. 3731) mars 2, 1895, s. $549-550$.

595 Clarke 1895, s. 563.

596 Borelius 1896, s. 430.

${ }^{597}$ Faulds 1895, s. 975.

598 Ibid.

${ }^{599}$ Rissler 1896, s. 671.
} 
borde det ha visat sig vid de otaliga kastreringar som genomförts under åren av andra orsaker, som vid tuberkulos, cystor, svulster och yttre skador. ${ }^{600}$ Han menade också att det i de flesta fall var svårt att reda ut om det var kastreringen i sig som låg bakom. Vissa av observationerna var "knappast af beskaffenhet att kunna läggas till grund för en allvarlig diskussion” enligt Rissler, och i andra fall hade det tydligt rört sig om en redan existerande sinnessjukdom som återkom eller försämrades. Samtidigt menade han att det fanns ett litet antal fall där "en sinnessjukdom af svårare eller lättare art utvecklat sig, skenbart som en direkt följd af kastrationen", men han föreslog att den kunde ha orsakats av spänningen och oron före operationen, narkosen eller liknande. Det var inte helt ovanligt att sådant inträffade efter operationer, oberoende av vad som opererades. ${ }^{601}$

I det fick Rissler medhåll av andra läkare och kirurger. Mansell Moullin menade att det var känt att sepsis, uremi och förgiftningar kunde ge upphov till tillstånd som akut mani, demens och depression, främst äldre patienter rapporterades uppvisa dessa negativa effekter. ${ }^{602}$ Kastrering innebar förvisso en större chock för kroppen än andra operationer som tog ungefär lika lång tid, men det var enligt Mansell Moullin tveksamt om dessa tillstånd orsakats av själva kastreringen. Prostatapatienter var ofta äldre och inte sällan var de psykiskt instabila redan före operationen, hävdade han, vilket i kombination med narkosen och operationen skulle kunna utlösa en störning. ${ }^{603}$

Två av Mansell Moullins patienter hade drabbats av intensiv depression och förvirring efter sin kastrering, men han menade att dessa tillstånd inte orsakats av

${ }^{600}$ Rissler 1896, s. 671.

601 Ibid.

602 Charles William Mansell Moullin, "The Effects of Unilateral Castration on the Prostate”, The British Medical fournal, vol. 1, nr. 1788, apr. 6, 1895c, s. 786 - 787.

603 Charles William Mansell Moullin, "Castration for Enlarged Prostate", The British Medical Fournal, vol. 1, nr. 1793, maj 11, 1895, s. 1065; Borelius 1896, s. 430 -431; Borelius 1897b, s. 642 - 643; Mansell Moullin 1894c, s. 976; Mansell Moullin 1895d, s. 786 - 787. 
avlägsnandet av testiklarna. Testiklarna hade ingen särskild kraft eller producerade någon substans som överfördes genom blodet, som vid inre sekretion, så det kunde inte vara förlusten av en sådan substans som utlöste sinnessjukdomen. Ett av de bevis han anförde för detta var att han endast hade avlägsnat den ena testikeln hos dessa patienter. Ett annat var att yngre män, där testiklarna definitivt var funktionella, inte drabbades av negativa följdverkningar efter kastrering. ${ }^{604}$

Inför sin artikel i Annals of Surgery och sitt föredrag inför the American Surgical Association i Detroit i maj 1896 hade Arthur Cabot sammanställt det som rapporterats om kastrering och psykisk påverkan. I elva av de 99 kastreringar han studerat hade ingreppet lett till psykiska störningar: "A serious maniacal condition occurred in six cases, and in five others there was considerable loss of mental balance with, in several, a melancholic tendency." ${ }^{605}$ Av de sex som drabbades av mani hade en patient tidigare uppvisat symptom på detta. ${ }^{606}$ Cabot nämnde inte om någon av patienterna avled av den negativa psykiska påverkan eller hur många av dem som tillfrisknade, men att döma av andra rapporter tillfrisknade de flesta patienterna.

I samma artikel accepterar Cabot en mortalitet på runt 20 procent för kastrering och olika former av prostatektomi. ${ }^{607}$ Dödligheten var föremål för diskussioner - flera läkare och kirurger i materialet menar att det inte var själva operationen utan andra orsaker som gjorde dödstalet så högt - , men till syvende och sist accepterade de flesta kirurger att runt en femtedel av patienterna dog av

\footnotetext{
${ }^{604}$ Mansell Moullin 1895c, s. 1065; Mansell Moullin 1895d, s. 786 - 787; Mansell Moullin 1896c, s. 349.

605 Cabot 1896, s. 271.

${ }^{606}$ Ibid, s. $271-272$.

607 Ibid, s. 270.
} 
kastrering medan flera vände sig mot att drygt en tiondel drabbades av en oftast övergående psykisk störning. ${ }^{608}$

I materialet finns inga jämförelser med hur många äldre män som påverkades negativt psykiskt av operationer som inte rörde könsorganen. Det är därför svårt att avgöra om läkare som varnade för kastrering menade att fler äldre män drabbades efter en kastrering än efter andra operativa ingrepp. Eller om vissa läkare ansåg att den negativa psykiska påverkan som drabbade äldre efter operationer på grund av exempelvis sepsis, narkos och uremi inte var samma påverkan som efter en kastrering. Vissa lyfte fram den psykiska påverkan som ett argument mot kastrering som behandling mot prostatahypertrofi, medan andra bara betraktade den som en effekt av tillstånd som ibland uppstod efter operationer, framförallt hos äldre.

Borelius hade i sina artiklar i Hygiea under 1896 och 1897 ställt sig överlag positiv till kastrering. Han hade hävdat att det inte fanns något stöd för uppfattningen att avlägsnandet av testiklarna skulle kunna medföra en sådan nedsättning av allmäntillståndet att det ledde till patientens död, men han hade varit mer försiktig i sina uttalanden om den psykiska påverkan av kastrering. Två av hans patienter hade uppvisat psykiska rubbningar efter operationen som inte kunde förklaras på något annat sätt än att de orsakats av kastreringen. Samtidigt hade en av Borelius patienter uppvisat det motsatta: kastreringen hade förbättrat hans psykiska tillstånd. Denna positiva förändring tillskrev Borelius mer urineringsbesvärens lindring än en direkt positiv påverkan av själva kastreringen. ${ }^{609}$ Han ifrågasatte rapporterna om patienter som dött av akut mani efter att ha kastrerats och föreslog att dödsorsaken kunde ha varit ett uremiskt eller toxiskt tillstånd. ${ }^{610}$

608 Se till exempel Mansell Moullin 1895c, s. 1064; White 1895, s. 112; Rissler 1896, s. 673. ${ }^{609}$ Borelius 1896, s. 430 - 431; Borelius 1897b, s. 606, 608, 632, 643.

610 Borelius 1896, s. 430. 
Vid Nordiska kirurgiska föreningens möte i Helsingfors den 12-14 augusti 1897 hävdade dock Borelius att kastrering var en stympande operation som kunde medföra allvarliga fysiska och psykiska rubbningar. Han sällade sig till dem som hade börjat argumentera för vasektomi som ett bättre alternativ för behandling av prostatahypertrofi. 611

\section{Försöken att få bukt med de negativa psykiska effekterna}

Alla läkare och kirurger som observerade negativa psykiska effekter hos sina patienter rekommenderade inte att man helt skulle avstå från kastrering, vissa försökte istället hitta ett sätt att behandla dem. En behandling som prövades var Brown-Séquards injektioner, vilka byggde på idéer om den manliga kroppen, testiklarna och framförallt spermiernas gynnsamma effekt på den manliga kroppen. Det fanns en föreställning om att det var hälsofarligt för män att göra av med för mycket spermier genom sexuella handlingar, både onani och samlag. Tanken om spermaekonomin, att män löpte risk att bli försvagade och till slut impotenta om för mycket sperma lämnade kroppen, bekymrade läkare generellt under 1800-talet. Män skulle idka avhållsamhet i rimlig utsträckning, alltså inte avstå sex helt men inte heller ägna sig åt det för mycket, och utöva självbehärskning. ${ }^{612}$

Inställningen till produktionen av spermier och deras påverkan på kroppen har sett olika ut under historien. Fram till 1700-talet var det lika bekymmersamt om en man behöll sin sperma för länge så att den ansamlades, fördärvades och kunde leda till allvarliga sjukdomar, som om han förlorade för mycket. Vid sekelskiftet 1700 började istället förlusten av sperma ses som det enda farliga . Läkarna tänkte sig att de spermier som inte lämnade kroppen togs upp i blodet

\footnotetext{
611 "Nordiska kirurgiska föreningens tredje...” 1897, s. 394.

612 McLaren 2007, s. 102; Ekenstam 1993, s. 141 - 146; Darby 2005a, s. 167 - 188; Darby 2005b, s. $283-319$.
} 
igen, vilket gjorde att kroppen återupptog den energi som förbrukats vid spermieproduktionen. ${ }^{613}$ Denna tanke utvecklades under 1700-talets gång och var fortfarande gällande under 1800-talet. Om testiklarna hade avlägsnats och kroppen hade berövats den energi som sperman ansågs innehålla kunde denna energi kanske ersättas genom injektioner med testikelextrakt.

Idén kom från Charles-Eduard Brown-Séquard (1817-1894), en franskamerikansk-mauretansk läkare som experimenterade på djur och 1889 gick ett steg längre och injicerade sig själv med testikelextrakt från hundar och marsvin. Inom forskning som gjorts om Brown-Séquard är det dock något oklart vad som låg bakom hans resonemang. Medicin- och biologihistorikern Merriley Borell menar att det initialt byggde på den gamla föreställningen om spermans energigivande egenskaper, alltså att förlust av sperma berövade den manliga kroppen livsviktig energi. Utan att kommentera det närmare menar hon att han mot slutet av 1880-talet istället talade om ett testikelextrakt. ${ }^{614}$ Historikern Timothy Verhoeven uttrycker dock tydligare att Brown-Séquard först utgick från spermans energigivande egenskaper men i slutet av 1880-talet ändrat detta till att testiklarna innehöll ett energigivande ämne som skulle kunna injiceras för att föryngra åldrande män och ge dem mer energi. ${ }^{615}$ Chandak Sengoopta har dock tolkat Borell som att det hela tiden handlade om en tanke om spermans energigivande egenskaper. Och dessutom att testikelextrak innebar i princip "spermiextrakt". 616

613 Stolberg 2000, s. $57-58$.

614 Merriley Borell, "Brown-Séquard's Organotherapy and its Appearance in America at the End of the Nineteenth Century", Bulletin of the History of Medicine, vol. 50, 1976, s. 3111 - 313; Sengoopta, 2002, s. 36 - 37; För en närmare beskrivning av spermaekonomin se Ben BarkerBenfield, "The Spermatic Economy: A Nineteenth Century View of Sexuality", Feminist Studies, vol. 1, nr. 1, sommaren 1972, s. $45-74$.

615 Verhoeven 2017, s. 95.

616 Sengoopta 2006, s. 37. 
Det fanns även en kvinnlig motsvarighet till testikelextraktet. 1897 introducerades ovarieextrakt som en behandling mot benvävsuppmjukning, något läkare kastrerat kvinnor för sedan slutet av 1880-talet. Sjuka ovarier hade ansetts ligga bakom sjukdomen, men under 1890-talet, när allt fler läkare började förklara sjukdomen med en sjuklig sekretion från ovarierna, introducerades en behandling med extrakt från friska ovarier. Denna byggde på en idé om inre sekretion. 617

Brown-Séquard tänkte sig att testikelextraktet skulle återge kroppen ungdom och vitalitet tack vare spermans, eller testiklarnas, vitaliserande ämnen. Denna behandling kom att kallas organterapi. ${ }^{618}$ I materialet jag undersökt dyker BrownSéquards extrakt upp i samband med kastreringens eventuella psykiska effekter. Rissler nämner Brown-Séquards experiment och hypoteser och Borelius föreslår hans injektioner som en behandling för patienter som uppvisar en negativ psykisk påverkan efter sin kastrering. ${ }^{619}$ Samtidigt blev Brown-Séquard hårt kritiserad av sin samtid och experimenten med testikelextrakt förstörde nästan hans goda rykte. ${ }^{620}$

Fredrik Ramm och William White var av åsikten att spermieproduktionen var den högsta cellverksamheten hos djur och att av testiklarnas två funktioner, spermieproduktionen och utvecklingen av den vuxna manliga kroppen, så var den första den mest specialiserade och komplicerade. ${ }^{621}$ Samtidigt hade denna uppdelning i testiklarnas två funktioner lett till en glidning i resonemanget om testiklarnas påverkan på den vuxna manliga kroppen. Den energiförlust eller påverkan på allmäntillståndet som bekymrade läkare vid kastrering knöts fortfarande till spermieproduktionen, men White spekulerade kring att de celler

\footnotetext{
617 Sengoopta 2006, s. $22-24$.

618 Borell 1976, s. 310; Sengoopta 2002, s. 36 - 37.

${ }^{619}$ Rissler 1896, s. 671; Borelius 1896, s. 431.

620 Sengoopta 2002, s. $36-37$.

${ }^{621}$ Ramm 1896, s. 31; White 1895d, s. 2 - 3.
} 
som bildade spermier kunde vara källan till den mystiska substansen som påverkade kroppens utveckling, snarare än själva spermierna. ${ }^{622}$

Den kritik som riktats mot Brown-Séquard hindrade inte läkare som Arthur Tracy Cabot från att prova injektioner med testikelextrakt på patienter som uppvisade psykisk påverkan efter kastrering. I en artikel 1896 beskrev Cabot en av sina egna patienter som drabbats av mani:

Previous to the operation the patient was for the most part clear mentally, but occasionally had slight confusion of ideas $[\ldots]$ after recovery from ether $[\ldots]$ in a distinctly bad mental condition the following day. From this time he continued in a mildly maniacal condition $[\ldots]$ and presented the typical form of confusional insanity, with occasional exacerbations when he was quite maniacal and noisy [...] February 19 he was as much confused as ever, his mind occupied with delusions and often much depressed, referring constantly in his talk to the loss of his testes and to his business troubles. It was now decided to try the effect of the injection of testiculin. ${ }^{623}$

Cabot började ge patienten injektioner med testikelextrakt. De var väldigt smärtsamma för patienten men verkade snabbt och förbättrade patientens psykiska tillstånd. Patientens vänner var mycket nöjda med den positiva effekten två dagar efter att injektionerna inletts. För att utesluta att det rörde sig om en placeboeffekt var Cabot noga med att varken patienten eller hans vänner kände till vilken behandling han fick.

När Cabot slutade med injektionerna blev patienten sämre och han upptog dem igen, trots att de fortfarande var mycket smärtsamma. En tid senare slutade Cabot återigen med injektionerna, och denna gång fortsatte patienten att bli bättre och kunde lämna sjukhuset. Cabots slutsats var att eftersom injektionerna

622 White 1895 d, s. $2-3$.

623 Cabot 1896, s. 272. 
hjälpte så snabbt mot manin så hade manin orsakats av avlägsnandet av testiklarna. ${ }^{624}$

Cabots experiment visar hur situerad kunskapsproduktionen kring mani som en effekt av kastrering och testikelextrakt som ett botemedel var. Patienten befann sig på ett sjukhus och behandlades av en läkare som kände till dessa injektioner och vad de skulle kunna användas till. Flera faktorer spelade sedan in i den process som gjorde testikelextraktet till ett botemedel mot mani orsakad av kastrering: läkaren observerade en förbättring, liksom patientens vänner, trots att varken de eller patienten visste vad det var för sprutor han fick. Samtidigt genomgick flera patienter en förbättring efter så kallad akut mani som uppstod efter kastrering utan behandling med testikelextrakt, ofta utan någon speciell behandling alls. Det fanns egentligen inget som pekade på att det faktiskt var injektionerna som var orsaken till förbättringen, men i och med att några läkare tyckte sig observera ett samband mellan injektionerna och en förbättring hos patienterna etablerades en föreställning bland dessa läkare att det var testikelinjektionerna som botade den akuta manin.

Även White rapporterade om en läkare som med gott resultat givit injektioner med testikelextrakt då en patient uppvisade tecken på mani efter en kastrering. ${ }^{625}$ Mansell Moullin hävdade däremot att alla de lyckade kastreringar han genomfört, dubbelsidiga såväl som ensidiga, pekade mot att det inte var operationerna som orsakade de psykiska störningarna och att man därför inte borde behandla dessa med injektioner av testikelextrakt. ${ }^{626}$

Det framgår inte av de diskussioner som publicerades exakt vad det var i injektionerna som läkare tänkte sig påverkade patienterna positivt, spermiernas

624 Cabot 1896, s. $273-274$.

625 White 1895 d, s. 4.

${ }^{626}$ Mansell Moullin 1896c, s. 349. Både Mansell Moullin och Jaques Borelius 1896, s. 430, nämner Cabots behandlingar av patienter med dessa injektioner. Mansell Moullin anger att Cabot presenterat detta för American Association of Genito-Urinary Surgeons i maj 1895. 
energi eller en inre sekretion från testiklarna. Cabot kallar den verksamma substansen "testiculin". ${ }^{627}$ Alla utgick dock i grunden från Brown-Séquards experiment och hypoteser, som initialt tycks ha baserats på tanken om spermaekonomin men senare på ett ämne från testiklarna.

\section{Könskörtlarnas påverkan på det manliga och kvinnliga psyket}

De negativa psykiska biverkningarna bekymrade en del av de läkare och kirurger som diskuterade kastrering som behandling för prostatahypertrofi. Även en del av de läkare som inte ansåg att dessa tillstånd av akut mani, psykos, demens, melankoli och så vidare orsakades av själva kastreringen diskuterade om kastrering kunde ha andra negativa psykiska eller fysiska effekter som påverkade allmäntillståndet. Jämförelser med kastrering av kvinnor togs upp, som att kvinnor med bristande njurfunktion hade uppvisat mani efter en kastrering. Men vilken var den allmänna inställningen till kvinnlig kastrering jämfört med manlig kastrering? Och vad var det för annan påverkan läkare och kirurger oroade sig för kunde drabba män efter kastrering?

Chandrak Sengoopta menar att maskulinitet under 1800-talet befann sig i utkanten av det medicinska intresset, medan femininet på många sätt stod i centrum. Det grundades ingen specialistinriktning för manlig reproduktiv eller sexuell medicin som motsvarade gynekologin, utan sådana problem behandlades av läkare från ett antal medicinska inriktningar. Ett undantag från ointresset var enligt Sengoopta kastrering. Den förste som genomförde experiment för att studera kastreringens effekter var John Hunter; han transplanterade bland annat testiklar från en tupp till en höna. Han betraktade experimentet som ett misslyckande då hönan inte förvandlades till en tupp. ${ }^{628}$

627 Cabot 1896, s. 272.

628 Sengoopta 2006, s. $28-30$. 
I de material jag studerat fanns många läkare och kirurger som intresserade sig för manlig kastrering och kastreringens påverkan på den manliga kroppen. Griffiths, som noggrant hade studerat testiklarnas funktion och påverkan på kroppen, menade att testiklarnas inverkan på utvecklingen av psyket var ett område där man ännu inte visste så mycket. Det var känt på vilket sätt eunucker skilde sig från män och liknade kvinnor i sin kroppskonstitution, men inte tillräckligt om psykets konstitution. ${ }^{629}$ Män som kastrerades i vuxen ålder blev enligt Grifftihs ofta "placid and content, though in some cases, as in the young man whose testes were removed by sir Astley Cooper, extreme misery may ensue". ${ }^{630}$ Han tyckte sig se en likhet mellan män som kastrerades prepubertalt och postpubertalt när det gällde påverkan på psyket: båda grupperna blev oftast lugnare och mer tillfreds. ${ }^{631}$

Harrison hävdade 1898 att det var tydligt att både kastrering och vasektomi inte bara påverkade det urogenitala systemet utan även gav upphov till störningar på hjärnan och negativ psykisk påverkan. Detta gjorde att de positiva förändringarna av prostatan vid kastrering hade ett alltför högt pris. Han menade att den långsammare process som en vasektomi innebar, där blodkärl och ibland även nerver skars av så att först testiklarna och därefter prostatan atrofierade var mindre riskfylld. ${ }^{632}$ Eunucker sågs som feminiserade män, och att vuxna män som kastrerades skulle kunna feminiseras oroade vissa läkare och kirurger. Motsvarande oro och oenighet fanns när det gällde kastrering av kvinnor - att de skulle bli maskuliniserade. ${ }^{633}$

\footnotetext{
629 Griffiths 1895b, s. 794.

630 Ibid.

631 Ibid.

632 Reginald Harrison, "Remarks on the Surgery of the Vas Deferens Relative to Some Urinary Disorders", The Lancet, vol. 151, nr. 3880 (ursprungligen publicerad som volym 1, nr. 3880) jan. 8, 1898, s. 94.

${ }^{633}$ Moscucci 1990, s. 157.
} 
År 1886 inträffade en uppmärksammad kontrovers kring en brittisk gynekolog som anklagades för att alltför ofta ha opererat bort kvinnors ovarier i situationer där man tidigare använt palliativa metoder. En undersökningskommitté tillsattes för att utreda fallen. Utredningen resulterade dock i konstaterandet att kvinnorna inte maskuliniserats efter kastreringen. Mer bekymmersamt var det faktum att kastreringen tyckts orsaka äktenskaplig olycka då många kvinnor rapporterat att de märkbart förlorat sina sexuella känslor. ${ }^{634}$ Tre år senare, 1889, skrev Hegar att kvinnor efter kastrering behöll lusten och förmågan att ha samlag, till skillnad från män, som nästan alltid förlorade såväl lusten som förmågan. Resultatet av det var enligt Hegar att män drabbades av nedstämdhet, melankoli och självmordstendenser. Kvinnor, i och med sin förmåga att fortfarande känna lust och genomföra samlag, drabbades inte av dessa negativa mentala effekter efter kastrering. 635

Liksom testiklarna ansågs viktiga för mannens sexuella aktivitet, nervsystem och psyke, ansågs äggstockarna vara viktiga för kvinnans, och ansågs dessutom spela en viktig roll i menstruationscykeln. ${ }^{636}$ Att avlägsna ovarierna, det som gjorde kvinnor till kvinnor, hotade deras position i samhället, natur och moraliska ansvar. De olika formerna av ovariotomi hotade att göra kvinnor könlösa och dessa ingrepp var därför enligt Ornella Moscucci de mest kritiserade av de gynekologiska behandlingarna under 1800-talet, både inom läkarvetenskapen och i samhället i stort. ${ }^{637}$ Många av de kvinnor som kastrerades eller genomgick ovariektomi var i fertil ålder, och ingreppet påverkade deras främsta roll i samhället: den som hustru och moder. ${ }^{638}$ Att en motsvarande diskussion om män som kastrerades som behandling mot prostatahypertrofi lyste med sin frånvaro

\footnotetext{
634 Moscucci 1990, s. $160-164$.

635 Sengoopta 2006, s. 21.

636 Ibid, s. $13-14$.

${ }^{637}$ Moscucci 1990, s. 134, 157, 159

638 Ibid, s. 157.
} 
berodde främst på att de absolut flesta av dessa män hade passerat vad som ansågs vara den manliga reproduktiva perioden.

Intressant nog var en av de viktigaste indikationerna för kvinnlig kastrering att bota kvinnlig sinnessjukdom. Orsaken till sinnessjukdom hos kvinnor ansågs i vissa fall vara sjuka eller defekta ovarier. ${ }^{639}$ Hos män ansågs kastrering tvärtom kunna orsaka sinnessjukdom och framförallt akut mani - det som motverkade mani hos män fanns i testiklarna. Kastrering användes därför aldrig för att försöka bota manlig sinnessjukdom, trots att samma teori om ovariernas nervpåverkan på kroppen användes för att förklara testiklarnas påverkan på kroppen. ${ }^{640}$ När män som led av olika former av psykisk ohälsa kastrerades var det för att förhindra reproduktion. ${ }^{641}$ Cabot nämner dock i förbigående att det fanns fall då nervös lättretlighet hos män hade botats av operationen, även om syftet inte hade varit att bota dessa besvär. ${ }^{642}$

Flera läkare, även i mitt material, framhöll skillnaderna mellan testiklarna och ovarierna, utan att närmare precisera vad de bestod i. Sengoopta menar att det berodde på att kvinnans kropp betraktades som biologiskt instabil och patologisk. Enligt Sengoopta ansågs sex och reproduktion inte vara centralt för den manliga organismen på samma sätt som för den kvinnliga. ${ }^{643}$

Vissa läkare likställde dock ovarier och testiklar i det avseendet att de hade lika stor inverkan på den kvinnliga kroppen som på den manliga. ${ }^{644}$ Ernst Haeckel (1834-1919) konstaterade 1868 i sitt tvåvolymsverk Natürliche Schöpfungsgeschichte att hos människan, liksom hos alla ryggradsdjur, var de kvinnliga och manliga organen i embryot exakt desamma och skillnaderna mellan de två könen

${ }^{639}$ Johannisson 1995, s. 195.

640 Sengoopta 2006, s. 31.

${ }^{641}$ Dale 2010, s. 46 - 47; Bryant 2012, s. 241.

642 Cabot 1896, s. 274.

${ }^{643}$ Se till exempel Mac Munn 1893, s. 709; Sengoopta 2006, s. 31.

${ }^{644}$ White 1895d, s. 2 - 3; Mansell Moullin 1894b, s. 909. 
framträdde endast gradvis under embryots utveckling. Det medförde att förändringar i ovarierna hade lika stor påverkan på den kvinnliga kroppen som förändringar i testiklarna hade på den manliga. ${ }^{645}$ Studier av eunucker och kastratsångare hade visat testiklarnas betydelse för den manliga utvecklingen. Haeckel citerade Virchows berömda utsaga: "Woman is woman only by her sexual glands.”646 Haeckel tycks ha menat att det samma gällde för män:

\begin{abstract}
Among these correlations in the formation of different organs, those are specially remarkable which exist between the sexual organs and other parts of the body. No change of any part reacts so powerfully upon the other parts of the body as a certain treatment [castration] of the sexual organs. ${ }^{647}$
\end{abstract}

Det hade gjorts försök att reda ut hur testiklarna påverkade prostatan men även kroppen i övrigt. I debatten kring kastrering var läkarna särskilt intresserade av körtlarnas funktion för den psykiska hälsan, men också av om avlägsnandet kunde leda till defeminisering och demaskulinisering. Det var känt att könskörtlarna påverkade utvecklingen av manliga och kvinnliga sekundära könskaraktärer och att ett avlägsnande före puberteten resulterade $\mathrm{i}$ en avvikande utveckling. Sengoopta menar att "[t]he oophorectomists, however, either ignored the possibility of generalized defeminization or denied that the removal of ovaries in adult life could bring that about." 648 I materialet om manlig kastrering har jag funnit att vissa läkare att inte tog upp skillnader i testiklarnas påverkan på kroppen hos yngre och äldre vuxna män, medan andra livligt diskuterade frågan. Åsikterna

${ }^{645}$ Jag har utgått från den engelska översättningen, Ernst Heinrich Philipp August Haeckel, The History of Creation. Or the development of the Earth and its Inhabitants by the Action of Natural Causes. London, H. S. King \& Co. 1880, s. 244. Både William White och Fredrik Ramm lutar sig mycket på denna text i sina resonemang om testiklarnas påverkan på kroppen.

${ }^{646}$ Haeckel 1880, s. 245.

647 Ibid, s. 243.

648 Sengoopta 2006, s. 20. 
gick isär: Hade testiklarna en stor påverkan även på äldre mäns kroppar trots att de ansågs ofunktionella? Eller försvann denna påverkan helt redan när den vuxna kroppen var färdigutvecklad och var därför påverkan lika stor hos äldre män?

Redan tidigt i kastreringsdebatten varnades det för att kastrera män lika oreserverat som man kastrerat kvinnor eftersom den kvinnliga kastreringen hade fått kritik, både utanför och inom medicinvetenskapen. White skrev i en artikel 1897:

The indiscriminate oöphorectomy of a few years ago, when all sorts of vague nervous symptoms were held to justify the removal of the ovaries, which were said to be pathological if a minute cyst or a slight fibroid change could be found, is happily a thing of the past. ${ }^{649}$

I samma artikel uttryckte han oro inför inställningen att vara alltför benägen att operera och drog paralleller till samtidens operationer av urinröret och blindtarmen, vilka han hävdade utfördes av samma kirurger som några år tidigare glatt opererat bort ovarier. White menade att man kunde förvänta sig en viss tendens hos dessa personer att behandla kastrering för prostatahypertrofi på samma sätt, men det fanns inget $\mathrm{i}$ hur han framställt användningen av denna operation som rättfärdigade detta. Han hade varit tydlig från början med att kastrering inte var ett universalmedel mot alla prostataproblem. ${ }^{650}$

Flera andra kirurger vände sig mot avlägsnandet av friska organ. Spencer Wells, som introducerat ovariektomin i England och opererat ett stort antal kvinnor, motsatte sig starkt att "hans" operation nu användes på indikationer som han inte kunde skriva under på. ${ }^{651}$ Alfred Hegar, som var den som introducerat

${ }^{649}$ William White, "Castration and vasectomy in hypertrophy of the prostate", University Medical Magazine, april, 1897, s. 471.

650 White 1897, s. 471.

${ }^{651}$ Johannisson 1995, s. $196-197$. 
kvinnlig kastrering i Tyskland, betonade att det var mycket viktigt att läkaren försäkrade sig om att patientens symptom hade en patologisk orsak i äggstockarna. ${ }^{652}$ Trots kritiken kastrerades kvinnor på psykiatriska indikationer in på 1900-talet. ${ }^{653}$

Jämförelsen med kastrering som behandling av uterusmyom var ett av de argument som gjorde att kastreringen av män med prostataförstoring infördes, samtidigt som somliga varnade för att metoden inte hade fungerat speciellt bra på kvinnor och därför inte skulle göra det på män heller. White var den ende som explicit lyfte fram den massiva kritik som riktats mot kvinnlig kastrering, men det finns all anledning att tro att kritiken, tillsammans med föreställningar om skillnaden mellan kvinnor och män när det gällde kastrering, var ett skäl till att kastrering av män med friska testiklar aldrig nådde samma omfattning som kastreringen av kvinnor. Dessa jämförelser fick sannolikt en stor påverkan på kunskapsproduktionen om kastrering som behandlingsmetod för prostatahypertrofi.

Whites varning tycks delvis bottna $\mathrm{i}$ att han befarade att manlig kastrering skulle börja användas för andra prostataproblem, precis som ovariektomi först hade använts för att behandla specifika sjukdomar i ovarierna och sedan delats upp i två ingrepp: ovariotomi och kastrering. Kastrering hade i sin tur använts för att behandla en uppsjö andra åkommor, som endast löst kunde kopplas till ovarierna. När vi ser tillbaka på perioden idag kan den bild flera studier målat upp kring inställningen till testiklar och maskulinitet göra att det framstår som en mycket osannolik utveckling att kastrering av män skulle ha spridit sig till andra åkommor på ett liknande sätt som kastrering av kvinnor hade gjort. Men samtidens manliga läkare tycks ha betraktat det som ett verkligt hot. White uttryckte oro över att "hans" operation skulle missbrukas på det sätt som Spencer

652 Sengoopta 2006, s. 17.

${ }^{653}$ Johannisson 1995, s. 197. 
Wells upplevde att "hans" introduktion av ovariektomin i England hade missbrukats. ${ }^{654}$ I Storbritannien blev kastrering av kvinnor aldrig lika populärt som i Amerika på grund av inställningen hos de brittiska läkarna att ingreppet inte bara gjorde kvinnorna sterila, vilket hotade deras roll i samhällsordningen, utan det påverkade deras sexuella lust negativt och orsakade en maskulinisering av deras kroppar, vilket hotade det heterosexuella äktenskapet. ${ }^{655}$

En av de mest intressanta sakerna med dessa jämförelser är spänningen mellan att läkare och kirurger ständigt tittade på den kvinnliga kroppen för att förstå den manliga och att vissa samtidigt framhöll de stora skillnaderna. Här berättades flera parallella vetenskapliga berättelser om kastrering. Vissa läkare menade att ovarier och testiklar som lika viktiga för utvecklingen av kroppen hos kvinnor och män, och att kastrering hade lika stor påverkan på den kvinnliga som den manliga kroppen. Vissa menade också att både kvinnor och män drabbades av negativ psykisk påverkan och förlorade sin sexdrift. Andra menade att det fanns en skillnad mellan ovarier och testiklar, utan precisera vad den var, och menade att kastrering påverkade kvinnor och män helt olika, att kvinnors psykiska ohälsa kunde botas med kastrering, och/samt att kastreringen inte påverkade deras sexdrift eller deras psykiska hälsa negativt. Under den period jag studerat utkristalliserades aldrig någon enhetlig vetenskaplig berättelse om ovariers och testiklars påverkan på kroppen. Inte heller fanns det någon enhetlig berättelse om hur kastrering påverkade kvinnor och män. Istället fanns det ett antal olika berättelser och för vissa läkare och kirurger var en eller flera av dem argument mot att kastrera män för prostatahypertrofi.

654 White 1897, s. 471; Johannisson 1995, s. 196 - 197; Moscucci 1990, s. 158.

655 Moscucci 1990, s. 157. 


\section{Kastreringens fall}

But, Sir, there is something repugnant in this operation which is not relieved by such jealousy displayed in the rush for its perpetration, and one thinks of the possibility of any alternative procedure. ${ }^{656}$

James MacMunn i The British Medical fournal 1895 angående kastrering.

Redan från början fanns det ett motstånd hos vissa läkare och kirurger mot kastrering som en behandling mot prostatahypertrofi. Harrison var det mest framträdande namnet, men även andra fann operationen frånstötande, stympande och farlig. Därför började flera läkare och kirurger undersöka möjligheten till ensidig kastrering eller vasektomi (ensidig eller dubbelsidig), eller så fortsatte de att utveckla andra metoder, som suprapubisk prostatektomi, alltså att kirurgen gick in via ett snitt i buken ovanför blygdbenet. James MacMunn vände sig i det inledande citatet inte bara mot själva operationen utan mot att det under 1895 förekom en del bråk i bland annat British Medical fournal om vem som varit först med operationen. Istället för att uppehålla sig vid detta borde läkarkåren ägna sig åt att hitta en alternativ behandlingsmetod.

När seklet gick mot sitt slut kom även andra faktorer att påverka kastreringens vara eller icke vara. Kirurgin och medicinen i stort genomgick snabba förändringar som påverkade förutsättningarna för att behandla olika sjukdomar. Att avlägsna sjuka organ, körtlar och vävnader hade fram till 1880-

${ }^{656}$ James MacMunn, "Castration for Prostatic Hypertrophy", The British Medical Journal, vol. 1, nr. 1776, jan. 12, 1895, s. 110. 
talet varit kirurgins största framsteg. Kirurger undvek ofta vissa delar av kroppen, som buken, på grund av den höga risken för infektioner, men i början av 1890talet började riskerna minska och allt fler kirurger var beredda att öppna upp buken och operera. ${ }^{657}$ Att kirurger i början av 1900-talet kunde redovisa avsevärt lägre mortalitetssiffror skulle, i kombination med bättre kirurgiska tekniker, förändra förutsättningarna för prostatektomierna.

Kritiken mot kastrering för prostatahypertrofi hade inte låtit vänta på sig. Redan innan White och Ramm föreslog behandlingsmetoden hade andra läkare dragit samma slutsatser men av olika anledningar undvikit att presentera samma förslag. När White och Ramm publicerade sina artiklar 1893 var det många som tog emot förslaget positivt, men inte alla. Redan under 1895 riktades allt hårdare kritik mot behandlingsmetoden, även av personer som initialt varit positiva. Kritiken tilltog under slutet av 1890-talet då allt fler nackdelar rapporterades. Trots detta skulle läkare och kirurger fortsätta att kastrera män som led av prostatahypertrofi några år in på det nya århundradet.

Timothy O'Neill hävdar att kastrering som behandling vid prostatahypertrofi användes mellan 1893 och $1902 .{ }^{658}$ Den svenske läkaren G. Bäärnhielm skrev dock 1903:

Från 1898 eller 1899 synes kastrationen och vasdeferens-resektionens roll vara utspelad, ity att den flod af publikationer, som i detta ämne under de föregående åren öfversvämmat facktidskrifterna, då synes vara i det närmaste utsinad. ${ }^{659}$

I materialet framkommer en viss oenighet kring hur länge behandlingsmetoden faktiskt användes. I The Lancet 1903 sammanfattades diskussionerna om

657 Schlich 2017, s. 50, 53.

658 O’Neill 2003, s. 129.

${ }^{659}$ G. Bäärnhielm, "Ett fall af perineal prostatektomi”, Hygiea, band 63, del 2, september, 1903, s. 222. 
prostatabehandlingar vid British Medical Associations möte i Swansea och ett av Harveian Societys möten. Kastrering och vasektomi beskrivs där som att det nästan helt övergivits. ${ }^{660} 1904$ argumenterade Cuthbert Wallace för att kastrering borde överges helt, vilket tyder på att metoden fortfarande praktiserades. ${ }^{661}$ Och samma år beskrev Freyer kastrering och vasektomi som behandlingsmetoder som "passed into oblivion". ${ }^{662}$

Även om Bäärnhielm hade rätt i att publikationerna i ämnet redan i slutet av 1890-talet minskade kraftigt så övergavs inte behandlingsmetoden helt förrän några år in på 1900-talet. Det är svårt att ange ett exakt årtal men efter 1904 tycks de så kallade genitaloperationerna, som kastrering och vasektomi allt mer kom att benämnas som, inte längre nämnas som något som fortfarande användes i någon egentlig mening. Diskussionerna kring behandlingar av prostatahypertrofi fortsatte men de flesta hade redan några år tidigare övergivit kastrering och vasektomi till förmån för andra behandlingar.

\section{Kritiken mot kastrering}

\section{De osäkra resultaten}

Ett problem som allt mer utkristalliserades var att effekterna av kastrering och vasektomi var osäkra. Dels var det svårt att avgöra vem som skulle bli hjälpt, och om symptomen förbättrades eller rentav försvann så var det inte säkert att effekten skulle bli bestående. När statistik över operationerna sammanställdes, speciellt närmare slutet av 1890-talet, fanns det en stor slumpmässighet i vem som blivit hjälpt, och en stor osäkerhet om huruvida förbättringen berodde på själva

660 "Surgery", The Lancet, vol. 162, nr. 4191 (ursprungligen publicerad som volym 2, nr. 4191) dec. 26, 1903, s. 1792.

661 "Pathological Society of London", The Lancet, vol. 164, nr. 4234 (ursprungligen publicerad som volym 2, nr. 4234) okt. 22, 1904, s. 1150 - 1151.

662 Freyer 1904, s. 197. 
operationen eller de palliativa åtgärderna före operationen. ${ }^{663}$ Resultaten av vasektomin, som vissa velat ersätta kastreringen med, var inte så goda som man hade hoppats. $\AA$ ena sidan var det ingen som rapporterade om direkt negativa effekter, men å andra sidan var det många patienter som upplevde ringa symptomlindring eller ingen alls även efter en längre tid. 664

Under de sista åren då kastrering användes för att behandla prostatahypertrofi gjordes det försök att reda ut dessa slumpmässiga resultat. Läkare och kirurger delade in prostatahypertrofi i tre grupper, och förstoringens form avgjorde vilka behandlingsmetoder som skulle kunna hjälpa. Kastrering och vasektomi blev allt mer två behandlingsmetoder bland andra. En generell förstoring, ofta med mycket blodstockning, kunde behandlas framgångsrikt med kastrering, vasektomi eller möjligtvis Bottinis operation. En förstoring med utväxter, ofta polypliknande, behandlades bäst med någon form av prostatektomi via perineum, och om förstoringen bestod av adenom i prostatan var en suprapubisk prostatektomi att föredra. ${ }^{665}$

Prostatahypertrofi, eller prostataförstoring (enlargement of the prostate) som allt fler av de anglo-amerikanska läkarna började kalla det, kom att ses som ett samlingsnamn på flera skilda tillstånd. Skillnaderna gällde både hur den urogenitala apparaten påverkades och hur prostatans form och struktur

${ }^{663}$ James H. Nicoll, "The Treatment of Chronic Enlargement of the Prostate", The British Medical fournal, vol. 2, nr. 1974, okt. 29, 1898, s. 1316; "Nordiska kirurgiska föreningens tredje...” 1897, s. 392 - 393; Peter Johnston Freyer, "Two Clinical Lectures on Enlargement of the Prostate", The Lancet, vol. 157, nr. 4038 (ursprungligen publicerad som volym 1, nr. 4038) jan. 19, 1901c, s. 153.

${ }^{664}$ Reginald Harrison, "Remarks on Vasectomy Relative to Enlarged Prostate and Bladder Atony", The Lancet, vol. 155, nr. 4001 (ursprungligen publicerad som volym 1, nr. 4001) maj 5, 1900, s. 1275.

665 "Prospects in Genito-Urinary Surgery", The Lancet, vol. 157, nr. 4056 (ursprungligen publicerad som volym 1, nr. 4056) maj 25, 1901, s. 1487. 
påverkades. Att försöka hitta en metod för att bota dem alla framstod alltmer som en omöjlighet.666 Både kastrering och vasektomi följde med som alternativa behandlingsmetoder in på de första åren av 1900-talet, men ingen av dem framställdes längre som den operation som skulle bota alla patienter med en förstorad prostata. 667

Vid ett av The Pathological Society of Londons möten 1904 menade Cuthbert Wallace att kastrering borde överges helt eftersom man fortfarande inte hittat ett sätt att räkna ut när operationen säkert skulle ge god effekt. ${ }^{668}$ Möten i The British Medical Association och The Harveian Society året innan hade resulterat i samma konstateranden. Kastrering och vasektomi hade under en kort period åtnjutit tillfällig uppskattning, men nu hade båda ingreppen nästan totalt övergivits. ${ }^{669}$ Dessa åsikter började också leta sig in i litteraturen om prostatahypertrofi, och E.L Keyes och van Burens The Surgical Diseases of the GenitoUrinary Organs från 1903 innehåller ett avsnitt där både kastrering och vasektomi döms ut som verkningslösa för att behandla prostatahypertrofi i alla dess former. ${ }^{670}$

En viktig beståndsdel i en övertygande vetenskaplig berättelse om prostatahypertrofi och kastrering eller vasektomi som behandlingsmetod var med vilken säkerhet resultaten kunde förutses. De första rapporterna hade varit överväldigande positiva och nästan alla patienter tyckes bli bättre, $\mathrm{i}$ alla fall av

666 Reginald Harrison, "On some Structural Varieties of the Enlarged Prostate Relative to its Treatment", The Lancet, vol. 154, nr. 3962 (ursprungligen publicerad som volym 2, nr. 3962) augusti 5, 1899, s. $331-332$.

${ }^{667}$ W. Bruce Clarke, "Prostatectomy In Two Stages, With An Account Of Seven Cases", The British Medical Fournal, vol. 2, nr. 2077, okt. 20, 1900, s. 1184.

668 "Medical Societies..." 1904, s. $1150-1151$.

669 "The Annus Medicus" 1903, s. 1792.

670 "Reviews and notices of Books", The Lancet vol. 161, nr. 4164 (ursprungligen publicerad som volym 1, nr. 4164) juni 20, 1903, s. 1745 - 1746. 
kastrering. Effekten av vasektomi hade hela tiden varit mer ifrågasatt. En del av intra-aktionen mellan läkaren, prostatan och genitaloperationerna bestod i att läkaren mätte, rapporterade och publicerade sina resultat, och på dessa rapporter vilade kunskapsproduktionen och den vetenskapliga berättelsen om kastrering som behandlingsmetod. När rapporterna inte längre visade goda effekter försvagades den vetenskapliga berättelsen. Runt sekelskiftet 1900 var det inte längre många läkare och kirurger som ansåg att effekterna var tillräckligt bra för att motivera en fortsatt användning. Och det fanns fler argument mot kastrering.

\section{Motståndet från patienterna}

Ett av de stora problemen med kastrering redan från början var att patienterna inte ville bli kastrerade. ${ }^{671}$ De sa inte ja förrän de kände sig desperata och deras allmäntillstånd mycket försvagat, vilket bidrog till operationens höga dödlighet ännu 1897 låg den på 19 procent. ${ }^{672}$ Antalet patienter med prostatahypertrofi som kastrerades var inte endast beroende av hur många läkare och kirurger som ansåg detta vara en fungerade eller acceptabel behandlingsmetod. Till stor del påverkade patienternas möjlighet att säga nej hur ofta behandlingsmetoden användes.

Patienter var beredda att undvika sjukhusvård och specialistläkare och stå ut med sina problem hellre än att genomgå en kastrering. Freyer beskrev 1909 att han träffat en patient som nio år tidigare sökt hjälp för sina problem. Den specialistläkare patienten då hade träffat hade föreslagit kastrering, men patienten motsatte sig det och "kept clear of specialists" under de följande nio åren. ${ }^{673} \mathrm{Nu}$

${ }^{671}$ Ramm 1896, s. 57.

672 "The Lancet,: London: Saturday, November 13, 1897”, The Lancet, vol. 150, nr. 3872

(ursprungligen publicerad som volym 2, nr. 3872) nov. 13, 1897, s. 1258 - 1259.

673 Peter Johnston Freyer, "A recent series of 212 cases of Total Enucleation of the Prostate, With Special Reference to Octogenarians", The British Medical fournal, vol. 2, nr. 2544, okt. 22, 1909, s. 965. 
hade dock problemen blivit så svåra att han återigen tvingades söka specialisthjälp. ${ }^{674}$

De flesta kirurger drog sig själva för att föreslå kastrering så länge patienten var ung nog att ha fungerande testiklar. Det var en av de främsta skillnaderna mellan kastrering av män och av kvinnor under denna period. Prostatapatienterna som diskuterats i detta material ansågs ofta vara så pass gamla att det inte sågs som ett problem att operationerna påverkade deras reproduktiva eller sexuella funktion. Freyer skrev:

\begin{abstract}
No man will consent to have his testicles removed for the purpose of preventing future prostatic troubles whilst anything remains of their physiological function; and even when all virile power is lost patients shrink from emasculation through the consciousness of being thereby unsexed. ${ }^{675}$
\end{abstract}

Även bland de patienter som var så gamla att testiklarna inte längre hade någon fungerande produktion av spermier var det få som gick med på kastrering. Oavsett om läkare och kirurger ansåg att detta bara var sentimentalt så var det en reaktion som de betraktade som mänsklig och som de var tvungna att hantera i praktiken. ${ }^{676}$ Motståndet hade lett till att kastrering ofta genomfördes på svårt sjuka patienter, vilket höjde dödligheten, och till att kirurger hade börjat undersöka möjligheten att genomföra en vasektomi istället. ${ }^{677}$ Patienternas motstånd mot att bli kastrerade påverkade alltså praktiken eftersom läkare och kirurger inte kunde kastrera i ett tidigt skede av sjukdomsprocessen. När detta fick till följd att dödligheten fortsatte att vara hög utforskades istället andra behandlingsalternativ som vasektomi. Att man övervägde vasektomi istället för

\footnotetext{
${ }^{674}$ Freyer 1909, s. 965.

675 Freyer 1901c, s. 153.

676 White 1895a, s. 12; White 1895d, s. 58; Freyer 1901c, s. 154.

${ }^{677}$ Freyer 1901c, s. $153-154$.
} 
kastrering motiverades även av det motstånd vissa läkare och kirurger kände mot att kastrera och oron för hur en kastrering påverkade kroppens allmäntillstånd.

\section{Statistikens roll}

Något som hela tiden fanns med i debatten om kastrering och vasektomi var statistik om och numeriska redovisningar av hur många som genomgick någon form av genitaloperation, hur väl ingreppen fungerade, hur många som dog samt hur många som blev bättre och hur.

Sedan mitten av 1700-talet hade statistik och numerisk rapportering blivit viktiga inom medicinen. Främst på folkhälsoområdet, där statistik över beteende och hälsa användes, och något förändrade användes även dessa statistiska metoder för och påverkade klinisk och terapeutisk medicin. Framför allt var det publikationerna med flera sammanställda fall under 1700-talet som blev viktiga. En effekt av detta var att läkare och kirurger började analysera effektiviteten av olika behandlingsmetoder, utifrån olika faktorer som ålder, kön, diagnos och så vidare, numeriskt. ${ }^{678}$ I slutet av 1800-talet var detta en viktig del av medicinen vilket syns i rapporteringen om genitaloperationerna: statistik över mortalitet och förbättringar, och mot slutet olika operationers effekter på olika former av förstoringar, var en central del av utvärderingen av kastrering som behandlingsmetod.

Medicinen var vid den här tiden internationell, och information rörde sig snabbt mellan europeiska länder och den nordamerikanska kontinenten. Detta gällde även statistiska sammanställningar som ofta innehöll siffror ifrån flera länder. Till exempel publicerade den amerikanske kirurgen Alfred Wood i maj 1900 en artikel där han redogjorde för flera av de större sammanställningar som tidigare gjorts och därtill redogjorde han för de fall som rapporterats men inte

${ }^{678}$ W. F Bynum, Science and the Practice of Medicine in the Nineteenth Century, Cambridge Univ. Press, Cambridge, 1994, s. $42-44$. 
tagits upp i White eller Cabots sammanställningar. ${ }^{679} \mathrm{I}$ sammanställningen tar Wood upp von Bruns 148 fall varav 74 var amerikanska, 33 från England, 21 från Tysland, 12 från Sverige och Norge, 4 från Frankrike och Ryssland sammanlagt och 4 fall som var von Bruns egna. ${ }^{680}$ De fall som Wood lade till dessa sammanställningar hade publicerats i tidskrifter från Amerika, Kanada, England, Tyskland, Frankrike, Norge och så vidare. ${ }^{681}$ Han hade till och med ett fall publicerat i Australasian Medical Gazette från september 1895, men de flesta var publicerade i nordamerikanska och europeiska tidskrifter. ${ }^{682}$

Under slutet av 1890-talet diskuterade läkare och kirurger hur många som faktiskt kastrerats, bland annat vid ett av Nordiska kirurgiska föreningens möten i augusti 1897 och tre månader senare på ett möte i Paris med Association Française d'Urologies som leddes av Guyon. The Lancets korrespondent menade att det mest intressanta och viktigaste ämnet som avhandlades i Paris var moderna behandlingar av prostatahypertrofi. ${ }^{683}$

Kastrering beräknades i november 1897 ha utförts i mer än 500 fall i Nordamerika och Europa, trots att var svårt att avgöra på förhand vilka patienter som skulle bli hjälpta. ${ }^{684}$ Statistiken över patienter som genomgått en genitaloperation för prostatahypertrofi i Sverige, Norge och Danmark hade sammanställts utifrån vad Ramm, Lundsgaard, Borelius och Lennander hade rapporterat i medicinska tidskrifter och i augusti 1897 var antalet 294 kastrationer och 114 vasektomier. ${ }^{685}$ Detta ska dock inte ses som den totala siffran utan som en

679 Alfred Wood, "The Result of Castration and Vasectomy in Hypertrophy of the Prostate Gland", Annals of Surgery, vol. 32, september, 1900, s. 309 - 350.

680 Wood 1900, s. 310.

681 Ibid, s. $316-350$.

682 Ibid, s. 331.

683 "London...", s. 1258.

${ }^{684}$ Ibid.

685 ”Nordiska kirurgiska föreningens tredje...”, s. 392. 
sammanställning av de försök som gjorts att samla in tillräckligt med kliniskt material för att dra slutsatser om kastreringen och vasektomins effekter. När kastrering väl föreslagits 1893 menade Harrison att behandlingsmetoden inom kort blev "somewhat extensively employed" och 1896 uppskattade han antalet genomförda operationer till flera hundra. ${ }^{686}$ Det kan ställas mot att antalet fall av kvinnlig kastrering som genomförts uppgick till 150000 operationer enligt en beräkning som gjordes 1906. Karin Johannisson menar att detta är en siffra som bör hanteras försiktigt, men även om den är överdriven visar den att kvinnlig kastrering var betydligt vanligare än manlig. ${ }^{687}$ Den största nackdelen med manlig kastrering var i slutet av år 1900 fortfarande den höga mortaliteten, runt 20 procent, vilken ansågs bero på patienternas ofta dåliga allmäntillstånd och höga ålder. ${ }^{688}$

Statistiska och andra numeriska redovisningar av kastreringens och vasektomins effekter hade använts och spelat en stor roll från början för att visa på behandlingsmetodens effektivitet. Initialt hade de pekat mot en god, till och med fantastiskt god, effekt, men mot slutet av perioden pekade de allt mer mot att kastrering och vasektomi inte var speciellt effektiva metoder. Ofta var förbättringarna kortvariga och patienterna återkom med nya problem. Kunskapsproduktionen kring kastrering som behandlingsmetod påverkades alltså av de statistiska och numeriska resultaten i och med att allt fler läkare och kirurger började ange de dåliga resultaten som ett skäl att överge genitaloperationerna.

\footnotetext{
${ }^{686}$ Reginald Harrison, "The Bradshaw Lecture on Vesical Stone and Prostatic Disorders", The Lancet, vol. 148, nr. 3824 (ursprungligen publicerad som volym 2, nr. 3824) dec. 12, 1896b, s. 1658.

${ }^{687}$ Johannisson 1995, s. 195.

${ }^{688}$ Freyer 1901c, s. 153.
} 


\section{Djurexperimenten}

Eter den initiala fasen förlorade djurexperimenten allt mer sin roll inom kunskapsproduktionen om kastreringens påverkan på prostatan. Det var inte direkta resultat från djurexperiment som gjorde att kastrering och vasektomi övergavs som behandlingsmetoder. Vid ett av Pathological Society of Londons möten 1904 sammanfattade Cuthbert Wallace kunskapen om kastrering och vasektomi så som den demonstrerats vid experiment på djur av flera läkare och kirurger. För det första var testiklarnas tillväxt och spermieproduktionen oberoende av att sädesledaren var oskadd. För det andra var prostatans utveckling, tillväxt och näringstillförsel beroende av att testiklarna fanns kvar men oberoende av sädesledarnas integritet. För det tredje hade det konstaterats att en normal utveckling av prostatan endast fordrade en fungerande testikel, oberoende av om sädesledarna var oskadda. För det fjärde att kastrering av unga djur medförde att prostatan atrofierade. För det femte att kastrering av vuxna djur medförde att prostatan atrofierade men att det dröjde innan det skedde, och slutligen att även om kastrering medförde att en frisk prostata atrofierade gick det inte att lita på att även en förstorad prostata gjorde det. ${ }^{689}$ Det sistnämnda, som fick Wallace att avråda från kastrering eller vasektomi som behandling mot prostatahypertrofi, var dock inte i strikt mening en slutsats som hade dragits av djurförsöken, eftersom inga av de djur som man experimenterade på led av prostatahypertrofi. Det var istället ett resultat av experiment på patienter. 690

Det hade hela tiden funnits en medvetenhet om att experimenten utfördes på friska djur, även om man valde ett experimentdjur, hundar, som kunde drabbas av en form av prostatahypertrofi. Ett intressant sammanträffande är att hundar kunde drabbas av prostatahypertrofi och att de sedan tidigare ofta valdes

\footnotetext{
689 "Medical Societies..." 1904, s. 1150. Även Freyer sammanfattar de kunskaper djurexperimenten bidragit med på ett liknande sätt i Freyer 1901c, s.154. 690 "Medical Societies...” 1904, s. $1150-1151$.
} 
som experimentdjur. Detta faktum kom att kvarstå även efter att kastrering och vasektomi hade börjat överges. Resultaten av djurexperimenten bidrog inte till att behandlingsmetodens effektivitet kritiserades, utan då hade fokus flyttats till operationernas resultat och påverkan på människor som led av prostatahypertrofi. Diskussionerna kring djurexperiment handlade istället om hur överförbara dessa resultat var från djur till människor: var förstoringen samma sjukdom hos djur och människor och fungerade djursprostator som människors?

\section{Behandlingarna som tog över}

När Cuthbert Wallace 1927 såg tillbaka på prostatakirurgins utveckling från 1886 konstaterade han att den hade varit långsam och smärtsam. Han menade också att "the general feeling of the profession can be gauged by the eagerness with which the so-called sexual operations were taken up". ${ }^{691}$ Genitaloperationerna förklarades av Wallace ha varit ett uttryck för den desperation som patienter och läkare kände inför svårigheterna att hitta en fungerande behandlingsmetod för prostatahypertrofi. ${ }^{692}$ Under 1800-talets allra sista år och i början av 1900-talet hade dock förutsättningarna förändrats. Kunskapsläget och tekniken gjorde att andra behandlingsmetoder tog över, i ny tappning eller med bättre möjligheter att fungera.

\section{Kateterisering}

Ett av de starkaste argumenten för att det behövdes en ny behandling mot prostatahypertrofi i början av 1890-talet hade varit problemen med kateteriseringen.

${ }^{691}$ Cuthbert Wallace, "A Review Of The Present Position Of Knowledge As To Prostatic Enlargement”, The British Medical fournal, vol. 2, nr. 3489, nov. 19, 1927, s. 907. 692 Wallace 1927, s. 907. 


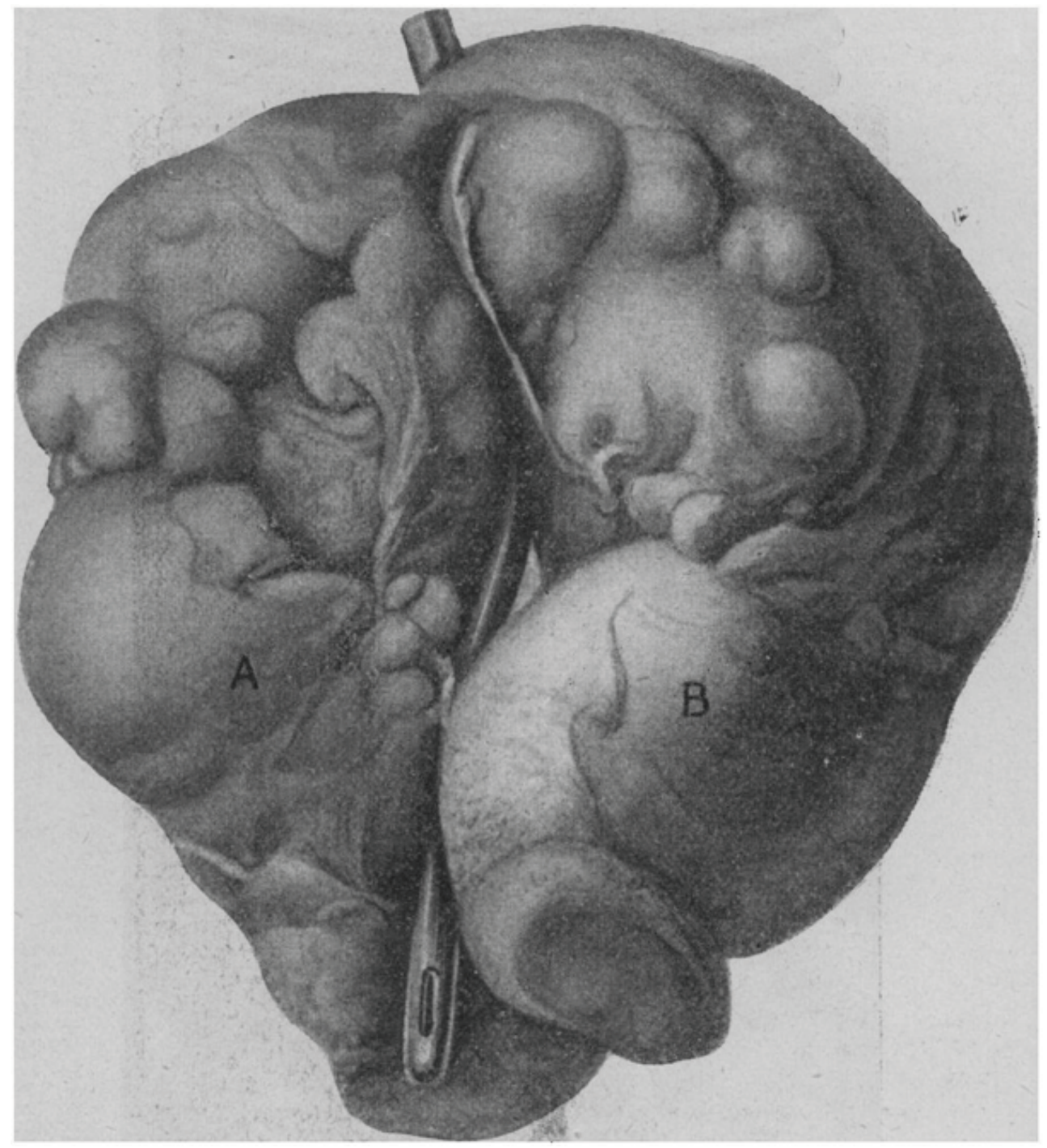

Bilden förställer en förstorad prostata som avlägsnats från en 68-årig patient med suprapubisk prostatektomi. Bokstäverna A och B markerar de två sidoloberna. I urinröret är en mjuk kateter placerad för att illustrera hur mycket urinrörets riktning påverkats av förstoringen. Källa: P. J. Freyer, "A Clinical Lecture On A Fifth Series Of Cases Of Total Extirpation Of The Prostate For Radical Cure Of Enlargement Of That Organ", The British Medical Fournal, vol. 1, nr. 2207, apr. 18, 1903, s. 899.

Dels gick det inte alltid att föra in en kateter och dels medförde det stora infektionsrisker. Mot slutet av 1890-talet lyftes dock kateteriseringen återigen fram 
som ett behandlingsalternativ. Under ett möte med Harveian Society den 1 april 1897 hävdade George Buckstone Browne att det aldrig var omöjligt att föra in en kateter i blåsan på patienter. I vissa fall var det svårt, när urinröret tryckts ihop av en förstoring av prostatan, men det fanns ett antal instrument för detta och det var alltid möjligt. Kastrering eller prostatektomi var alltså sällan nödvändigt. Buckstone Browne fick medhåll av Freyer, som menade att tålmodig och ren kateterisering var den bästa behandlingen vid prostatahypertrofi. ${ }^{693}$ Några år senare menade dock David Wallace att det var allmänt känt att när en patient trädde in i "kateterlivet", även om det bara var för en kortare period, så var det kantat av faror och ledde inte sällan till döden. Det största hotet var sepsis, enligt Wallace, och han framhöll hur viktigt det var med renlighet och sterila instrument vid kateterisering. ${ }^{694}$

Renligheten vid kateterisering uppmärksammas allt mer vid sekelskiftet 1900. Både kunskapen om bakterier och förutsättningarna för att hålla sin kateter ren och steril hade förbättrats. Läkare och kirurger var överens om att det var viktigt med sterilisering för att inte föra in bakterier i blåsan, speciellt vid sjukdomar som prostatahypertrofi vilka ofta medförde att patienten inte kunde tömma blåsan helt. Om blåsan kunde tömmas helt betraktades risken för att bakterier skulle växa till och orsaka en infektion inte vara speciellt stor. Alla var dock inte överens om ifall det viktiga var att sterilisera urinröret, urinrörsmynningen eller de katetrar och sonder som fördes upp. ${ }^{695}$

693 "Medical News. Harveian Society", The Lancet, vol. 149, nr. 3841 (ursprungligen publicerad som volym 1, nr. 3841) april 10, 1897, s. 1062.

${ }^{694}$ David Wallace, "An Adress in Tumors of the Bladder and Enlarged prostate", The Lancet, vol. 158, nr. 4063 (ursprungligen publicerad som volym 2, nr. 4063) juli 13, 1901, s. 66. 695 "Årsberättelse för arbetsåret 1897 - 1898. Förhandlingar vid Svenska Läkare-Sällskapets sammankomster år 1898”, Hygiea, band 60, del 2, 1898, s. 128 - 130. 


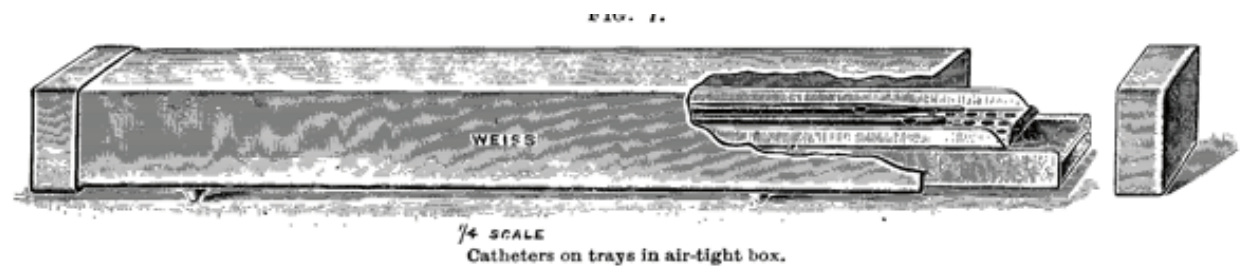

FIG. 8

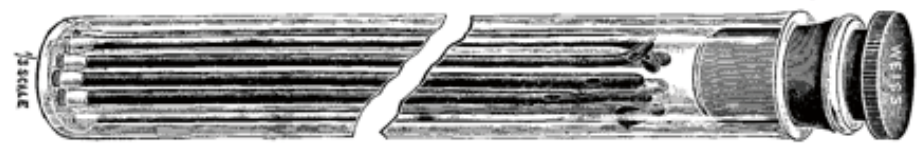

Glass tube steriliser.

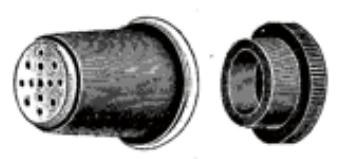

En lufttät ask för katetrar och en glastub för sterilisering av katetrar.

Källa: Peter Johnston Freyer, "Two Clinical Lectures on Enlargement of the Prostate", The Lancet, vol. 157, nr. 4038, jan. 19, 1901, s. 150.

Peter Johnston Freyer ägnade mycket tid åt att undersöka sterilisering av instrument för att kateterisering skulle fungera bättre. I de två föreläsningar han höll för Medical Graduates' College and Polyclinic i november 1900 gick han noggrant igenom kateterisering som behandlingsmetod. ${ }^{696}$ Detsamma gjorde Buckston Browne i sin The Harveian Lecture on Twenty-Five Years' Experience of Urinary Surgery in England 1901.697 Av föreläsningarna framgår att det som framförallt hade förändrats och förbättrats var att katetrar och sonder nu tillverkades i material som var lätta att sterilisera. Det fanns flera olika sätt att sterilisera dem, även sådana som patienten själv kunde genomföra i hemmet. Det fanns tydliga instruktioner för hur patienten skulle rengöra sina händer och sitt könsorgan innan katetern fördes in. Det fanns ett antal smörjmedel och lösningar som kunde underlätta införandet av katetern, och de innehöll substanser vars uppgift var att döda de bakterier som ändå följde med in.

\footnotetext{
696 Freyer 1901b, s. 79 - 81; Freyer 1901c, s. 149 - 156.

${ }^{697}$ G. Buckston Browne, ’The Harveian Lecture on Twenty-Five Years' Experience of Urinary Surgery in England. Lecture II", The Lancet, vol. 158, nr. 4082 (ursprungligen publicerad som volym 2, nr. 4082) nov. 23, 1901, s. 1395 - 1397.
} 
Resultaten av kateterisering skilde sig dock åt mellan sjukhuspatienter och privatpatienter. Privatpatienterna, vilka utgjordes av samhällets mer välbeställda, klarade sig längre med kateterisering eftersom de hade bättre förutsättningar att hålla instrumenten rena och att sköta sin personliga hygien. Sjukhuspatienter, som de patienter kallades som inte träffade läkaren privat utan på sjukhuset, hade sämre förutsättningar för att hålla sina katetrar rena hemma. ${ }^{698}$

Av Freyers publikationer om prostatabehandlingar framgår att tonläget hade förändrats något sedan början av 1890-talet kring prostatahypertrofi. I början av 1890-talet hade läkare och kirurger talat om prostatahypertrofi som något fruktansvärt som drabbade många män och skördade många liv, även om den statistik som publicerats visade att av de cirka 34 procent av alla män som drabbades av prostatahypertrofi var det bara 15-16 procent som uppvisade symptom, det vill säga ca. fem procent av den manliga befolkningen. ${ }^{699}$ Freyer höll till stor del med om dessa beräkningar som gjorts av Thompson med flera under 1870-talet av hur stor andel män som drabbades av prostatahypertrofi, men framhöll 1900 att det betydde att det aldrig varit speciellt många som någonsin led av symptom. ${ }^{700}$ Han förordade kateterisering i de allra flesta fall:

Holding, as I do, that in certain selected cases of this disorder an operation of some kind is advisable, and in a small minority imperative, to save the patient's life or ameliorate his sufferings, I have no hesitation in saying that in the vast majority the only admissible treatment is judicious and cleanly catheterism combined with careful hygienic living; and that by these means life will be more prolonged and existence rendered more tolerable than by any other. ${ }^{701}$

\footnotetext{
${ }^{698}$ Freyer 1901c, s. 149 - 151; Buckston Browne 1901, s. 1395 - 1397.

${ }^{699}$ Harrison 1888, s. 119; Harrison 1889, s. 126.

${ }^{700}$ Freyer 1901b, s. 79.

${ }^{701}$ Freyer 1901c, s. 149.
} 
Kateterisering, som alltid varit det första steget $\mathrm{i}$ att behandla problem med prostatan och urinering, rekommenderades i allt högre utsträckning som den enda behandlingsmetod som behövdes för många patienter. Operationer rekommenderades endast i de fă fall där de verkligen var nödvändiga. ${ }^{702} \mathrm{Vad}$ det gällde att rädda liv, vilket varit en framträdande del i diskursen när kastrering lanserades som behandlingsmetod i början av 1890-talet, så var även det nu nedtonat.

De förändrade förutsättningarna att framgångsrikt behandla prostatahypertrofi med endast kateter under en längre tid påverkade inställningen till att söka operativa lösningar överhuvudtaget. Detta stämmer överens med den allmänna utvecklingen inom kirurgin. Beredvilligheten att operera bort körtlar och organ var en del av den utveckling som har kallats medicinens fysiologiska era, vilken hade föregåtts av i tur och ordning den heroiska, anatomiska och patologiska eran. Kastrering som behandlingsmetod uppstod i skiftet mellan den patologiska eran - då kroppens sjukliga förändringar till stor del drivit medicinen och den mest framgångsrika metoden att behandla var att kirurgiskt avlägsna sjuka organ, körtlar och vävnader - och den fysiologiska eran - då kirurgin strävade efter att störa kroppens fysiologiska system så lite som möjligt. Den tidigare erans förkärlek för att operera bort sjuka delar sågs nu som barbarisk och onaturlig. Kirurgiska experiment handlade inte heller längre om att testa kirurgiska tekniker och operationer utan om att studera fysiologiska och patologiska processer för att kunna genomföra ingrepp som botade..$^{703}$

\footnotetext{
${ }^{702}$ För en längre diskussion kring kateterisering och prostatektomi se Herbert T. Herring, "The Relative Advantages Of Catheterization And Operation In The Treatment Of Prostatic Enlargement”, The British Medical fournal, vol. 2, nr. 2533, jul. 17, 1909, s. 136 - 138.

703 Schlich 2017, s. 62; Lawrence 1992, s. 1 - 47; Gert H. Brieger, "From Conservative to Radical Surgery in Late Nineteenth-century America", Christopher Lawrence (red.), Medical theory, surgical practice: studies in the history of surgery, Routledge, London, 1992, s. 229.
} 
Kirurgin präglades alltså av en viss konservatism i jämförelse med perioden innan. Det syns i mitt material framförallt hos Freyer och Buckston Browne, som förespråkar kirurgiska ingrepp men även återhållsamhet och palliativa åtgärder som kateterisering. Den nya inställningen baserades på upptäckter om att organ och kanske framförallt körtlar påverkade kroppen på tidigare okända sätt. ${ }^{704}$ Oron för vilken påverkan testiklarna hade på kroppen syns tydligt i materialet och fick följder för hur läkare och kirurger resonerade kring kastrering.

\section{Prostatektomi}

Utvecklingen av andra kirurgiska metoder upphörde inte när kastrering presenterades som en möjlig behandling mot prostatahypertrofi. Prostatakirurgi var under hela slutet av 1800-talet ett område i fokus för ett utbrett intresse bland läkare och kirurger. ${ }^{705}$ Trots att prostatektomin hade upp emot 40 procents dödlighet i början av 1890-talet övergav inte alla läkare dessa operationer till förmån för genitaloperationerna eller andra behandlingar. ${ }^{706}$ Mayo Robson, som hade fortsatt att utveckla teknikerna för prostatektomi, skrev 1898: "The fashion has for a time turned from prostatectomy to castration in the operative treatment of enlarged prostate, but I am by no means converted."707

${ }^{704}$ För ytterligare exempel på detta se även Bäärnhielm 1903, s. 225 - 226; För en längre diskussion kring återhållsamhet och prostatektomi se Andrew Fullerton, ”Note On A Series Of Fifty-Five Cases Of Suprapubic Prostatectomy, With Four Deaths", The British Medical Fournal, vol. 1, nr. 2720, feb. 15, 1913, s. 332 - 335; För organ och körtlars påverkan på kroppen se bland annat Schlich 2010.

${ }^{705}$ Freyer 1901c, s. 149; Harrison 1899, s. 332; Bäärnhielm 1903, s. 222 - 223.

706 Bäärnhielm 1903, s. $222-223$.

${ }^{707}$ Mayo Robson, "A Case of Suprapubic Prostatectomy, with the Subsequent History of the Patient", The British Medical fournal, vol. 1, nr. 1886, feb. 20, 1897, s. 456 - 457; Citerat i

Nicoll 1898, s. 1315. 
När sedan kastrering och vasektomi ifrågasattes allt mer, och allt färre patienter ansågs lida av en form av förstoring som skulle kunna avhjälpas med dessa operationer, började prostatektomi allt oftare att föreslås som ett alternativ speciellt för patienter som inte hade blivit hjälpta av kastrering eller vasektomi. ${ }^{708}$ McGills operation, som var en suprapubisk metod där endast delar av prostatan avlägsnades, framhölls 1901 som den bästa metoden för ett fåtal former av förstoringar. Den hade genomförts i England sedan 1888, men hade fått stå tillbaka till förmån för kastrering. ${ }^{709} \mathrm{McGills} \mathrm{metod} \mathrm{för} \mathrm{suprapubisk} \mathrm{prostatektomi}$ hade dock flera nackdelar: Dödligheten var hög, vilket delvis berodde på att kirurgen gick in via ett snitt i nedre delen av buken, ett av de sista områdena kirurgin hade erövrat på grund av den stora infektionsrisken. Och operationen misslyckades ofta med att återställa blåsfunktionen eftersom bara delar av prostatan avlägsnades och prostatan kunde växa till igen. Enligt Freyer 1904 utfördes ingreppet inte längre:

Owing to these considerations the operation, after enjoying a temporary and fitful notoriety for a few years, may be said to have died out of surgical practice. It was replaced, first by castration and later by vasectomy, which was practiced extensively during the closing years of last century. Experience has shown that both these procedures were practically useless and the former dangerous. They have now passed into oblivion. ${ }^{710}$

Freyer skulle dock åter sätta prostatektomin på kartan. Cuthbert Wallace skrev 1927 i en översikt över prostataoperationer sedan kastreringens införande att det var den serie av lyckade prostataoperationer som publicerades av Freyer från 1900

\footnotetext{
708 Nicoll 1898, s. 1316.

709 "Medical Society of London", The Lancet, vol. 155, nr. 3994 (ursprungligen publicerad som volym 1, nr. 3994) mars 17, 1900, s. 774; Freyer 1901c, s. 153.

710 Freyer 1904, s. 197.
} 
som återetablerade prostatektomierna. ${ }^{711}$ Freyer använde sig även han av en suprapubisk metod men nu avlägsnades hela prostatan, och inte bara delar som vid McGills metod. I november 1900 höll Freyer ett antal föreläsningar vid Medical Graduates' College and Polyclinic i London, vilka han sedan gav ut i en mindre bok, Clinical Lectures on Stricture of the Urethra and Hypertrophy of the Prostate. ${ }^{712}$ Han höll även ett föredrag inför Medical Society of London i mars 1900 där han presenterade en ny suprapubisk metod för prostatektomi. ${ }^{713}$ Året efter hade han genomfört fyra sådana operationer och publicerade resultaten i en längre artikel i British Medical fournal. Han var minst sagt postitiv:

These four operations have completely revolutionized my views with regard to the treatment of this painful and widespread malady, and I submit that the complete success with which they have been attended opens up a new and promising era in this field of surgery with far-reaching results. ${ }^{714}$

Några sidor längre fram konstaterade han att "we have at last arrived at a rational method of dealing with this painful and frequently fatal malady. ${ }^{715}$ Trots dessa framgångar var Freyer av åsikten att de flesta fall av

\footnotetext{
711 Wallace 1927, s. 907; Walker utnämner Freyer i sin historiska genomgång från 1930 till den som åter riktade intresset mot prostatektomier i och med sina fyra lyckade operationer publicerade 1901. John Thomson-Walker, "Enlarged Prostate And Prostatectomy", The British Medical Journal, vol. 1, nr. 3608, mar. 1, 1930, s. 403.

712 Peter Johnston Freyer, Clinical Lectures on Stricture of the Urethra and Hypertrophy of the Prostate, Baillière, Tindal, and Cox, London., 1901.

713 "Medical Society..." 1900, s. 774.

714 Peter Johnston Freyer, "A Clinical Lecture On Total Extirpation Of The Prostate For Radical Cure Of Enlargement Of That Organ: With Four Successful Cases", The British Medical fournal, vol. 2, nr. 2116, jul. 20, 1901d, s. 125.

715 Freyer, 1901d, s. 129.
} 
prostatahypertrofi bäst behandlades med "careful, cleanly, and judicious catheterisation". ${ }^{716}$

Dödligheten vid dessa operationer var 1907 så hög som 40 procent i Storbritannien som helhet, men avsevärt lägre hos vissa kirurger och kliniker. Ännu 1912 låg den kvar på samma nivå, men Freyer hade det året på Saint Peters Hospital en mortalitet på 5,1 procent och undrade hur mortaliteten fortfarande kunde vara så mycket högre för hela riket. ${ }^{717}$ Året efter hävdade Hugh Lett att mortaliteten vid prostatektomi förmodligen var runt 20 procent i genomsnitt om statistiken från ett stort antal sjukhus i Storbritannien sammanställdes, och Andrew Fullerton hävdade att av de 55 patienter han själv utfört prostatektomier på hade bara fyra (7,2 procent) dött. ${ }^{718}$ Enligt läkare och kirurger var det i regel inte själva operationen som var dödsorsaken, utan efterföljande eller befintliga komplikationer, precis som när det gällde kastrering.

I och med all den uppmärksamhet som kastrering och vasektomi riktat mot området prostatahypertrofi hade mycket ny kunskap skapats - även om kirurgerna runt sekelskiftet började bli mer och mer överens om att man hade använt operationerna för entusiastiskt och okritiskt och att resultaten inte varit så lysande. ${ }^{719}$ Ett framsteg var att man delade in förstoringarna in i olika kategorier och anpassade behandlingen till förstoringens form, struktur och symptom. En hel del av denna kunskap fördes över till prostatektomierna. McGills operation (ingång via nedre delen av buken) var ofta den som rekommenderades, och Dittels (ingång via perinuem) användes sällan före $1900,{ }^{720}$ men de flesta kirurger var

\footnotetext{
716 "Medical Society..." 1900, s. 774.

717 Peter Johnston Freyer, "One Thousand Cases of Total Enucleation of the Prostate for Radical Cure of Enlargement of that Organ", The British Medical Fournal, vol. 2, nr. 2701, okt. 5, 1912, s. 870.

718 Fullerton 1913, s. 332.

${ }^{719}$ Harrison 1899, s. 331.

${ }^{720}$ Freyer 1901c, s. 153.
} 
överens om att olika metoder fungerade bra för olika former av förstoring. Prostatan kunde förstoras i tre riktningar. Om det var mittenloben som orsakade problemen eller om de laterala loberna växte uppåt och tryckte på urinblåsan så var McGills operation att föredra. Om man förstoringen berodde på de laterala lobernas utvidgning var Dittels operation att föredra. ${ }^{721}$

Många kirurger undvek Dittels metod på grund av den ökade risken för komplikationer efteråt. Freyer ansåg att de beskrivningar som fanns inte var så uppmuntrande: patienten tvingades ofta ha kvar en fistel efter ingreppet eftersom urinröret och blåsan hade öppnats under operationen, och resultatet av operationen var sällan lyckat. ${ }^{722}$ När Cuthbert Wallace 1927 såg tillbaka på utvecklingen av prostatektomioperationerna i början av 1900-talet menade han dock att strax efter sekelskiftet fick operationer via perineum flera skickliga förespråkare och tekniken utvecklades och vann alltmer mark. ${ }^{723}$

Att prostatektomi alltmer ersatte kastrering berodde initialt inte på att mortaliteten hade sjunkit kraftigt eller på att den var lägre än för kastrering. Främst fungerade den bättre än genitaloperationerna för patienterna: urineringsförmågan återställdes, återfallen var färre och så vidare. Vad som ansågs vara en bra behandlingsmetod för prostatahypertrofi hade förändrats. Kunskapsproduktionen kring prostatahypertrofi - indelningen av förstoringarna i olika sorter och kunskapen om effekterna av olika operationer förändrade den vetenskapliga berättelsen.

Prostatektomierna började rekommenderas allt mer efter sekelskiftet, men de hade sina kritiker. Den danske professorn Thorkild Rovsing hade förståelse för viljan att hitta en metod som kunde hjälpa alla patienter med olika former av förstoringar, men med tanke på prostatektomins höga dödlighet kunde han inte

\footnotetext{
721 "Medical Society..." 1900, s. $774-775$.

722 Freyer 1901c, s. 153.

723 Wallace 1927, s. 907.
} 
dela den entusiasm som många uttryckt. Han menade vidare att kirurgerna lovade för mycket även med dessa operationer: det var vanligt att komplikationer tillstötte efter operationen, att symptomen inte förbättrades eller att de återkom med tiden. Rovsing motsatte sig också att man tog bort prostatan helt på grund av dess sexuella funktion. ${ }^{724}$

The Lancets korrespondent vid den sjunde skandinaviska kirurgkongressen i september 1907 skrev att det enligt Rovsing

\begin{abstract}
was highly to be regretted that the promoters of prostatectomy had removed hundreds of prostates, not only from old men but from men 40 and 50 years of age, without heeding the importance of the gland for the sexual functions, not knowing that the removal of the prostate produced not only impotence just as surely as a castration did but far oftener than a castration serious psychical derangements followed by suicide. ${ }^{725}$
\end{abstract}

Rovsing förordade istället suprapubisk cystostomi (en fistel in i urinblåsan genom buken där en permanent kateter infördes) som den operation som kunde hjälpa alla patienter oberoende av förstoringens form. Han hade själv fått mycket lyckade resultat med denna operation. I vissa allvarliga fall kunde prostatektomi vara nödvändigt, men det var då viktigt att kirurgen informerade patienten om att operationen innebar en stor risk, att den skulle leda till impotens och fysiska störningar och att han ändå kanske skulle bli tvungen att börja använda kateter igen. ${ }^{726}$

Rovsing var dock ensam vid kongressen om denna åsikt i frågan om prostatektomiernas inverkan på den sexuella förmågan. En av hans norska 724 "The Seventh Congress of Scandinavian Surgeons,: From Our Own Corresponent", The Lancet, vol. 170, nr. 4386 (ursprungligen publicerad som volym 2, nr. 4386) sep. 21, 1907, s. 862.

725 "The Seventh..." 1907, s. 862.

${ }^{726}$ Ibid, s. 863. 
kollegor, Dr. Gundersen, som argumenterade för att prostatektomi skulle användas i ännu större utsträckning, sade:

As to the important question about the influence of the operation on sexual potency, all surgeons using Young's method were of the opinion that the overwhelming majority of the patients kept what they might possess of potency before the operation. ${ }^{727}$

\section{En ny analogi}

De två konkurrerande hypoteserna om prostatahypertrofi och vilka behandlingar som kunde hjälpa, den franska skolan och analogin med uterusmyom, stod vid 1900-talets början kvar som de bästa förklaringarna, trots stark kritik. Freyer föredrog analogin med uterusmyom eftersom den öppnade för möjligheten att hjälpa patienterna på kirurgisk väg. Den franska skolans innebar i sin förlängning enligt Freyer att man inte borde ge patienten något annat än palliativ behandling. ${ }^{728}$ Men det fanns även andra idéer kring analogier och behandlingsmetoder.

I en artikel i The Lancet 1910 drog F. T. Paul en ny analogi: istället för att jämföra prostatan och uterus, eller prostatahypertrofi och uterusmyom, jämförde han prostatahypertrofi med kronisk mastit, alltså en inflammation i bröstet eller bröstkörteln. Paul menade att även om man inte hade samma kunskap om ovariernas påverkan på bröstkörtlarna genom inre sekretion som om testiklarnas påverkan på prostatan, så fanns det tillräckligt för att göra en jämförelse. Han medgav att det fanns få observationer av vad som hände med brösten hos en vuxen kvinna som genomgick en dubbel ovariektomi, men det fanns anledning att

727 "The Seventh..." 1907, s. 862.

${ }^{728}$ Freyer 1901b, s. 80. 
misstänka att brösten då atrofierade precis som prostatan atrofierade hos en vuxen man vid dubbel kastrering. ${ }^{729}$

Paul delade in mastit i tre olika varianter och fokuserade främst på den som kan uppstå under menopausen och som Paul kallade "involution", tillbakabildning. Tidigare hade prostatahypertrofi förklarats som en effekt av att testiklarnas inre sekretion kunde förändras med åldern. Nu menade Paul att det mycket väl kunde vara så att när ovariernas påverkan på brösten minskade på grund av minskad inre sekretion så kunde det uppstå problem med bröstkörtlarna. ${ }^{730}$

I Pauls resonemang blir det tydligt vad han ansåg att kvinnan och den kvinnliga kroppens roll var: att producera avkomma, gärna en stor skara. En ovariektomi störde den kvinnliga kroppens funktion, och om den inte fick användning av de reproduktiva funktionerna, genom att exempelvis amma ett barn, kom det till uttryck i sjukdomar som involutions-mastit. Paul hävdade att förloppet vid mastit var mycket likt det vid prostatahypertrofi. Både prostatan och brösten var sekundära sexuella körtlar som påverkas av de dominerande organen (testiklar respektive ovarier) till att utvecklas och vara friska. Vid inträdet av klimakterieperioden var de båda, prostatan och bröstkörtlarna, mottagliga för patologiska förändringar vilkas generella drag var mycket lika. Dessutom såg

${ }^{729}$ Redan 1904 hade ett liknande resonemang lagts fram av P. L. Daniel i en artikel där han försökte utreda prostatahypertrofins orsak. Han beskrev där de strukturella förändringar som sker vid prostatahypertrofi som "analogous in their origin to certain septic diseases of other duct glands, especially the brest and pancreas." Daniels analogi, eller likhet, mellan prostatahypertrofi och kronisk interstitiell mastit innebar här att de båda sjukdomarna berodde på bakteriella infektioner i körtlarna. P. L. Daniel, ” The Pathology Of Prostatic Enlargement", The British Medical fournal, vol. 2, nr. 2287, okt. 29, 1904, s. 1140 - 1145. ${ }^{730}$ Notera att när Paul skrev om testiklars och ovariers funktion och påverkan på kroppen 1910 var "inre sekretion" den vedertagna förklaringen till hur denna påverkan såg ut. En möjlig nervpåverkan, eller ett samband mellan nerver och inre sekrektion, nämns inte längre. Han använder dock inte ordet "hormoner". 
mikroskopiska prover av prostatahypertrofi och mastit mycket lika ut. Paul dömde ut de tidigare förklaringarna av varför prostatahypertrofi uppstod eftersom det fanns alltför många fall som inte stämde in. Istället menade han att det var en form av involution. ${ }^{731}$

Paul såg bröstkörtlarna och prostatan som lika eftersom de båda påverkades av könskörtlarna under puberteten, och han fann stöd för sin tes i mikroskopiska studier av vävnaden som visade på likheter. Så även om analogin med uterusmyom hade övergivits hade inte detta sätt att tänka och producera kunskap inom medicinen övergivits. Det var bara själva jämförelsen som varit felaktig, inte metoden.

\section{Ett komplext övergivande}

Det fanns flera orsaker som tillsammans gjorde att man slutade att behandla prostatahypertrofi med kastrering. Olika argument vägde olika tungt för olika personer, och läkare och kirurger kunde ha skilda uppfattningar om varför kastrering övergavs som behandling mot prostatahypertrofi.

Vid den sjunde skandinaviska kirurgkongressen i september 1907 menade professor Thorkild Rovsing att vasektomi och kastrering inte alls hade övergetts för att de var ineffektiva, som vissa hade hävdat, utan för att de var "stympande" och orsakade impotens. ${ }^{732}$ Många ansåg att kastrering medförde så allvarliga psykiska rubbningar att patienter dog av dem, men andra var inte övertygade om att så var fallet. Efter 1904 verkar dock behandlingsmetoden ha övergivits helt och de som inte övertygades av den påstådda psykiska påverkan verkar ha övertygats av andra orsaker. Mest framträdande i materialet är genitaloperationernas dåliga resultat: symptomen lindrades inte tillräckligt eller så återvände de. Därtill kom att patienterna motsatte sig kastrering, att möjligheterna att klara sig med

731 Paul 1910, s. 297.

732 "The Seventh...” 1907, s. 862. 
kateteranvändning förbättrades och längre fram att dödligheten vid prostatektomi minskade.

Statistik och numeriska framställningar av resultat framträder som mycket viktiga delar i kunskapsproduktionen kring vad som ansågs vara en fungerande och framgångsrik behandlingsmetod. När siffrorna inte längre framställde kastrering och vasektomi som lyckade metoder började läkare och kirurger ifrågasätta om de skulle användas. Detta är inte någon självklarhet inom medicinen - tonsillektomier användes länge utan att någon kunde visa på en faktiskt positiv effekt. ${ }^{733}$ Men i fallet med kastrering kom de resultat som kunde framställas numeriskt och statistiskt tack vare att stora mängder fall rapporterades och sammanställdes att spela en viktig roll.

När det kateterisering blev säkrare var det allt fler patienter och kirurger som valde den metoden istället för ett kirurgiskt ingrepp. I de fall då kateterisering inte räckte kom de förändrade operationsteknikerna för suprapubisk och perineal prostatektomi att erbjuda andra möjligheter för både patienter och kirurger, och många hävdade att prostatektomi på lång sikt hade en mycket bättre effekt än kastrering. Prostatektomin var en faktor vid övergivandet av kastrering, och framförallt beskrevs den i efterhand som en av anledningarna, men i materialet framträder ett glapp på några år mellan att kastrering mer eller mindre övergavs och att prostatektomi blev mer populärt och mortaliteten sjönk.

Kunskapsproduktionen kring prostatahypertrofi förändrades en del under den period då kastreringen var på väg att överges. Det fanns fortfarande ingen allmänt vedertagen förklaring till att prostatahypertrofi uppstod eller av vad den faktiskt var. Freyer skrev 1912:

I have analysed innumerable cases and devoted much time and thought to this subject, but I have to confess that I have still no insight into the origin of this disease;

${ }^{733}$ Grob 2007; Dwyer - Hemmings 2018. 
and my researches would indicate that all theories hitherto advanced on this subject have no foundation in fact. ${ }^{734}$

Däremot fanns det en utbredd uppfattning om att det fanns flera olika former av förstoring, en uppfattning som framförallt var följden av en intra-aktion mellan läkare, tekniska hjälpmedel som mikroskop och cystoskop och medicinska praktiker som obduktion och att man kirurgiskt tog bort delar av prostatan. Nya agentiella snitt drogs mellan olika former av prostataförstoringar. Förstoringarna klassificerades genom att läkare vid obduktion eller operation avlägsnade hela eller delar av prostatan och studerade dem i mikroskop för att avgöra vilken sorts vävnad förstoringen bestod av. De undersökte även sina levande patienter genom rektal palpering och med upplyst cystoskop och skaffade sig på detta sätt en bättre uppfattning om hur en prostata kunde förstoras. Kombinationen av vilken vävnad förstoringen bestod av och på vilket sätt den förstorades - de laterala loberna, den tredje loben, asymmetriskt eller symmetriskt -avgjorde vilken behandlingsmetod som valdes.

Kastrering som botemedel mot prostatahypertrofi visade sig ha en mer komplex bakgrund och historia än vad tidigare studier om kastrering och den medicinska inställningen under perioden visat. Testiklarna var långt ifrån så heliga som Laqueur och O'Neill menat, och manliga kirurger drog sig inte för att kastrera män i den utsträckning som bland andra Edward Shorter hävdat. Även om det definitivt fanns de som motsatte sig kastrering som behandling mot prostatahypertrofi redan från början, och de som blev avskräckta längs vägen, framträder en bild av en läkarkår som inte drog sig för att operera på de manliga könsorganen.

${ }^{734}$ Freyer 1912, s. 870. 


\section{Slutsatser}

Efter att ha följt behandlingsmetoden manlig kastrering för prostatahypertrofi och studerat den kunskapsproduktion som skapade prostatan, testiklarna och prostatahypertrofi som medicinska kunskapsobjekt vill jag nu sammanfatta mina resultat och diskutera några särskilt intressanta delar av dessa.

\section{Kunskapsobjekten}

Med utgångspunkt i Barads agentiella realism har jag visat hur prostatan och sjukdomen prostatahypertrofi skapades i intra-aktion mellan läkare, "apparater" och prostatan. Skapandet och intra-aktionen pågick kontinuerligt och förändrade prostatan och prostatahypertrofin. Vissa agentiella snitt bestod från 1800-talets början och under de följande hundra åren, som hur prostatan anatomiskt skilts från omgivande strukturer, medan andra har visat sig vara rörliga och omdebatterade. Prostatan skapades allt mer under perioden som en sekretbildande körtel och inte som en muskel. Testiklarna ansågs redan från början ha två funktioner (även om White spekulerade om ytterligare två andra funktioner) en reproduktiv och en mer allmän påverkan på kroppen och kroppens utveckling, men mot slutet av undersökningsperioden hade föreställningar om inre sekretion och nervpåverkan fått en allt större roll då avlägsnandet av testiklarna i vuxen ålder fått oväntade följder.

Under hela den period jag undersökt diskuterades huruvida prostatan var en körtel eller muskel och vad dess funktion var, samt vad prostatahypertrofi var, som anatomisk förändring och som sjukdom. Begreppet "prostatahypertrofi” kvarstod, men innebörden förändrades. Det fanns fortfarande ingen allmänt accepterad 
förklaring till att hypertrofin uppstod eller vad den rent patologiskt var, men en tillväxt av adenom blev mot slutet av perioden den förklaring som många läkare och kirurger angav.

Den stora förändringen av prostatahypertrofin var de agentiella snitt som delade in sjukdomen i flera varianter beroende på vilka delar av prostatan som förstorades och vilken sorts vävnad förstoringen bestod av. Olika sorters behandling lämpade sig för olika sorters förstoringar: Om sidoloberna var förstorade lämpade sig vissa operativa ingrepp bättre än om den tredje loben var förstorad. Om prostatan kändes hård, vilket tydde på tillväxt av främst bindväv, lämpade sig prostatektomi bättre, och om prostatan kändes mjuk och förstoringen främst bestod av körtelvävnad lämpade sig kastrering bättre.

Det var inte bara de vetenskapliga berättelserna om prostatan och prostatahypertrofin som förändrades under den studerade perioden, utan även vilka berättelser som var möjliga att berätta och accepterades. De processer som hela tiden pågick, vilka förändrade synen på prostatan och prostatahypertrofi, hindrade inte att behandlingar föreslogs, användes och övergavs trots att grundfrågorna inte hade fått något definitivt svar. Barads agentiella realism är ett sätt att analysera detta skapande och omskapande av medicinska kunskapsobjekt.

En förklaring till att föränderlighet och det ständiga omskapandet av kunskap och kunskapsobjekt inom medicinen inte motsäger att den medicinska praktiken ändå fungerar är att medicinen kan sägas vara uppdelad i tre praktiker, som intraagerar men även kan fungera mer autonomt i förhållande till varandra: teori, experiment och klinisk erfarenhet. Idealt bör de sammanfalla så att teorin förklarar något som experimenten underbygger och som visar sig fungera i den kliniska praktiken. Men när det gällde kastrering som botemedel mot prostatahypertrofi sammanföll de inte. Teorin om en analogi mellan uterus/uterusmyom eller prostatan/prostatahypertrofi var redan från början hårt ifrågasatt och sågs som ohållbar. Samtidigt var det en teori som pekade mot en viss behandlingspraktik, och därför var flera läkare och kirurger beredda att ställa 
sig bakom den för att kunna prova behandlingen kastrering. Även om de var medvetna om teorins brister hade de erfarenhet av att vissa behandlingar fungerade kliniskt även om det teoretiska underlaget inte höll. Det var möjligt att berätta en vetenskaplig berättelse för att teoretiskt underbygga en behandlingsmetod, även om underlaget för berättelsen i sin tur var mycket svagt.

\section{Experimenten}

Kastrering som behandlingsmetod studerades med hjälp av experiment på människor såväl som djur. Djurexperimenten hade en viktig roll inom praktiken att kastrera för prostatahypertrofi. Det är mycket vanligt att läkarna och kirurgerna i mitt material hänvisar till sina egna eller andras experiment på djur och vad de har visat.

Med begreppen "spektrum" och "avlivningsbarhet" kunde jag visa att valet av experimentdjur påverkades av hur lika de var människor, på ett spektrum från helt annorlunda till väldigt människolika. Experimentdjuren skulle vara lika människor - de flesta valde hundar som experimentdjur på grund av att deras prostata är sammanväxt på ett liknande sätt som människors och att de ansågs kunna drabbas av prostatahypertrofi - men det fanns en gräns för hur lika de fick vara. Resultaten av experimenten måste ses som överförbara till människor, men djuren måste också befinna sig i rätt del av spektrumet för avlivningsbarhet. Djurexperimenten bidrog till den vetenskapliga berättelsen om förhållandet mellan testiklarna och prostatan och om kastreringens påverkan på prostatan. Vetenskapliga berättelser kan alltså vara artöverskridande.

\section{Den kliniska erfarenheten}

Det var experimenten på människor - så beskrev Mansell Moullin hela praktiken att kastrera - som i slutänden blev ett av de tyngsta argumenten för att överge kastreringen som en behandling mot prostatahypertrofi. Här sammanföll 
experimentens praktik med den kliniska erfarenhetens. I längden visade den kliniska erfarenheten, som ofta presenterades i statistiska sammanställningar, att behandlingsmetoden sällan gav långsiktig lindring. Läkare och kirurger hade hoppats på att den svaga teoretiska grunden inte skulle spela någon roll när den kliniska erfarenheten visade att kastrering fungerade, men den kliniska erfarenheten visade tvärtom att kastrering oftast inte fungerade.

Om den kliniska erfarenheten hade visat att behandlingen fungerade så hade både den teoretiska underbyggnaden och djurexperimenten i längden varit av mindre betydelse eller inte särskilt relevanta alls. Men den vetenskapliga berättelsen var mer beroende av att den kliniska erfarenheten visade att behandlingsmetoden fungerade än ett korrekt teoretiskt underlag.

\section{Kvinnokroppen}

Andra mänskliga kroppar än den "normala" manliga kroppen användes i stor utsträckning för att skapa kunskap om prostatan, om prostatans förhållande till testiklarna, om prostatahypertrofi som sjukdom och om möjliga behandlingsmetoder. Framförallt lyftes den kvinnliga kroppen fram i och med de analogier som låg till grund för kastrering som behandlingsmetod - mellan prostatan och uterus, mellan prostatahypertrofi och uterusmyom och mellan förhållandet mellan ovarier och uterus och förhållandet mellan testiklarna och prostatan. Den kvinnliga kroppen framställdes som den kropp läkarvetenskapen i detta sammanhang hade betydligt större kunskap om, och överföringen av en behandlingsmetod från gynekologin till den begynnande urologin utgjorde grunden till hela förslaget om kastrering. Det fanns inget motstånd mot att se kvinnokroppen som "facit". Tvärtom sågs det som en fördel att kunna koppla de tumörer man tyckte sig se i prostatan till en redan känd grupp tumörer i uterus.

Många läkare betraktade förhållandet mellan ovarier och uterus som likartat det mellan testiklarna och prostatan. Vissa ville framhäva en skillnad mellan kvinnokroppen och manskroppen, utan att de egentligen specificerade vad den 
bestod i, medan andra såg förhållandet som helt motsvarande hos män. En närstudie av den medicinska materiellt-diskursiva praktiken visar att det inte alls rådde en så stark eller dominerande föreställning om att kvinnokroppen och manskroppen var diametralt olika som tidigare medicinhistoriska studier påstått. Dessa studier fokuserade mer på det omgivande samhället och uppfattningar som förmedlades av vissa läkare eller lekmän till allmänheten, och ger alltså en annan bild av hur fysiska könsskillnader uppfattades. De framstående och tongivande läkare och kirurger som deltog i debatten om kastrering som en behandling mot prostatahypertrofi framställde inte manskroppen som norm eller "facit" och hade inte heller några uttalade problem med att se kvinnokroppen som jämförbar med manskroppen och en behandlingsmetod för en "kvinnosjukdom" som överförbar till en "manssjukdom".

Den kritik som riktats mot tidigare forskning när det gäller synen på mäns och kvinnors kroppar inom medicinen av bland andra Benninghaus och Darby har inspirerat mig att göra en närstudie av den inommedicinska debatten och praktiken kring kastrering vid prostatahypertrofi. ${ }^{735}$ Den generella bilden av mäns och kvinnors roll i samhället under en period säger inte alltid så mycket om hur de medicinska praktikerna såg ut, och att som tidigare forskning avfärda manlig kastrering som omöjlig för att testiklarna ansågs vara "heliga" eller för att manliga läkare var ovilliga att kastrera andra män medför att vi går miste om kunskap om den manliga kroppen inom medicinhistorien.

\section{Avvikande manliga kroppar}

Förutom den kvinnliga kroppen användes avvikande manliga kroppar för att skapa kunskap om den "normala" manskroppens sjukdomar men även dess "normala" funktion. Det finns en lång historisk tradition av att bland annat hermafroditer har studerats för att skapa kunskap om den "normala" kroppen. I

${ }^{735}$ Benninghaus 2012; Darby 2005a. 
detta fall jämförde man med män som av naturliga orsaker eller till följd av ett mänskligt ingrepp saknade en eller båda testiklarna.

Kategoriseringar av dessa kroppar, och försök att utreda hur de olika tillstånden påverkade prostatan, användes för att skapa kunskap om kastreringens påverkan på den manliga kroppen. Utan hormonteorin som förklaring var förhållandet mellan testiklarna och prostatan okänt, även om mycket kunskap överfördes från vad man ansåg sig veta om förhållandet mellan ovarier och uterus. Utifrån observationer av personer som fötts utan en eller båda testiklarna och som fått en eller båda testiklarna avlägsnade före eller efter puberteten försökte man förklara detta förhållande utan hormonteorin och samtidigt undersöka kastreringens påverkan på prostatan.

Många läkare och kirurger tonade ner rädslan för feminisering av män som kastrerades postpubertalt. De erfarenheter som fanns av eunucker visade att prepubertal kastrering påverkade och feminiserade den manliga kroppen, men de fall av manlig postpubertal kastrering som fanns att tillgå pekade på att testiklarna inte påverkade kroppen alls i samma utsträckning i vuxen ålder. Överlag är den positiva inställning till manlig kastrering som läkare och kirurger i materialet uttrycker intressant. Debatten handlade initialt inte om ifall män borde kastreras eller inte, snarare om ifall kastrering utifrån kunskapsläget var en logisk lösning på problemet med prostatahypertrofi. De äldre män som vägrade låta sig kastreras beskrevs som sentimentala och som ett problem för läkare och kirurger. Att yngre män motsatte sig kastrering sågs dock som naturligt. Det var först när kastreringens negativa psykiska påverkan uppmärksammades som vissa läkare och kirurger i debatten började argumenterade mot kastrering som behandlingsmetod.

\section{Agentiell realism}

Min studie har visat på den komplexitet som präglar medicinsk kunskapsproduktion och skapandet av medicinska kunskapsobjekt. Att utgå från Barads 
agentiella realism med intra-aktion mellan subjekt, "apparater" och objekt kan tyckas enkelt, men praktiken är alltid mycket mer komplicerad och mångfacetterad. Intra-aktionen för att skapa kunskapsobjekt som prostata, prostatahypertrofi och testiklar innefattade läkare och kirurger och deras förkunskaper, förförståelser och kontakter med varandra, genom texter och vid personliga möten, liksom objekt och medicinska tekniker som operationer. Den innefattade även kroppar - "normala" mäns, kvinnors, avvikande mäns och djurs - och vissa kunskaper ansågs vara direkt överförbara från en sorts kropp till en annan, vissa delvis överförbara och andra inte alls överförbara. Intra-aktionen med dessa kroppar styrdes av förkunskaper och förförståelser, av vilka apparater som användes och av kropparnas materialitet. Till detta kom den kontext läkare och kirurger intra-agerade med i form av medicinska institutioner, tidskrifter och utbildningar. Utanför detta fanns det omgivande samhället, men enligt den avgränsning jag gjort, eller om man så vill de agentiella snitt jag gjort för att genomföra studien, tillhör det en annan analys.

Med agentiell realism kan man studera vilket kunskapsobjekt som helst. Oavsett om det är materiellt, diskursivt, historiskt eller samtida är det möjligt att med de teoretiska verktygen agentiell realism, agentiella snitt samt intra-aktion mellan subjekt, "apparater" och objekt studera hur ett kunskapsobjekt skapas, förändras och försvinner. Agentiell realism är speciellt användbar vid studier på detaljnivå, som den jag genomfört, eftersom den gör det möjligt att analysera alla delar av intra-aktionen. Framför allt finns dock en fördel när objektet som studeras är materiellt, även om det är en semiotisk beskrivning av det materiella objektet som i detta fall, eftersom analysen tar hänsyn till den materiellt-semiotiska diskursen. Vid studier av skapandet av ett materiellt objekt som prostatan vinner analysen på att ta hänsyn till prostatan som ett materiellt objekt som både tillåter och gör motstånd mot vissa vetenskapliga berättelser, men även intra-agerar med subjektet och "apparater" i detta skapande. 
Läkarnas placering av agentiella snitt styrdes både av deras förförståelse för kroppen och av kroppens materialitet, som gjorde motstånd mot vissa snitt och möjliggjorde andra. Fördelen med en analys som ligger så nära den beskrivna medicinska praktiken är att jag kunnat studera hur de förförståelser läkare och kirurger hade, ofta uttryckta i teoretiska resonemang om kroppen, påverkade intra-aktionen och placeringen av de agentiella snitten. Jag har även kunnat få syn på när kroppens materialitet har gjort motstånd: när Harrison ville göra prostatan till en muskel gjorde prostatans anatomi och dess funktion så som den kunde observeras motstånd, vilket innebar att de agentiella snitt han gjorde inte accepterades av andra läkare, och det gjorde inte heller den vetenskapliga berättelse han försökte berätta om prostatan.

\section{Manlig kastrering}

Enligt Laqueur och Shorter, och senare O'Neill och Sengoopta, hade läkare och kirurger under den period jag undersökt en mycket restriktiv inställning till manlig kastrering. ${ }^{736}$ Det har tidigare beskrivits som en konsekvens av tidens föreställningar om kön och manliga läkares och kirurgers motvilja mot att kastrera andra män - i kontrast till deras beredvillighet att kastrera kvinnor. Båda dessa påståenden bör dock revideras. Tidigare forskning har visat att det även fanns ett starkt motstånd mot kvinnlig kastrering och i denna studie har jag kunnat visa att inställningen till manlig kastrering inte alls var så restriktiv inom läkarkåren. Under 1890-talet var detta så välkänt att bland andra William White kommenterade det, och uppmuntrade till viss återhållsamhet även vid kastrerandet av män. Moscucci, Nilsson och Frampton bekräftar att kvinnlig kastrering var ifrågasatt, och Whites tydliga avståndstagande visar att det fanns en oro för att manlig kastrering skulle användas på ett liknande sätt. ${ }^{737}$ Det fanns

736 Laqueur 1992; Shorter 1992; O’Neill 2003; Sengoopta 2006;

737 Moscucci 1990; Nilsson 2003, s. 149 - 152. 
läkare som helt motsatte sig manlig kastrering, men många såg inga problem med att kastrera män för att bota prostatahypertrofi om det visade sig fungera.

Enligt mina resultat var frågan om manlig kastrering mycket mer komplex under slutet av 1800-talet än vad den tidigare forskningen framställt den som. ${ }^{738}$ Kvinnlig kastrering var inte under 1800-talet och det tidiga 1900-talet accepterad överallt av alla, och att avlägsna friska testiklar var inte otänkbart för tidens läkare. Inte ens senare under 1900-talet var manlig kastrering otänkbart som behandling mot prostatabesvär, vilket jag återkommer till strax.

\section{Vikten av inommedicinska studier}

Christina Benninghaus har kritiserat den "sociala essentialism" som under lång tid dominerat medicinhistorisk forskning och genusforskning. Hon skriver:

\footnotetext{
"Social essentialism" - here understood as a tendency to attribute historical change a priori to broader social or cultural, rather than internal scientific or medical developments, and to interpret innovations in science and medicine as a direct reflection of cultural demands or problems - has at times hampered advances in gender history. Likewise, the political aim of criticising the medical treatment of women has sometimes led to a certain indifference regarding the fate of male patients. ${ }^{739}$
}

${ }^{738}$ För med komplexa framställningar om ras och ovariotomi se Deirdre Cooper Owens, Medical Bondage: Race, Gender, and the Origins of American Gynecology, Athens: university of Georgia Press, 2017; För kvinnliga läkares roll i främjandet av ovariotomi och kvinnliga patienters aktiva roll beroende på samhällsklass se Regina Morantz-Sanchez, Conduct Unbecoming of a Woman: Medicine on Trial in Turn-of-the-century Brooklyn, Oxford: Oxford University Press 1999; Clair Brock, British Women Surgeons and Their Patients, 1860-1918, Cambridge: Cambridge University Press 2017.

739 Benninghaus 2012, s. 647. 
Jag håller med Benninghaus om att breda sociala och kulturella förklaringar i alltför hög grad har givits företräde i förklaringar av historiska förändringar inom medicinen, och om föreställningen att medicinska innovationer skulle drivas av ett direkt behov hos det omgivande samhället. Jag håller också med om att den politiska fokuseringen på att kritisera hur kvinnor behandlats inom medicinen har gjort att manliga patienter många gånger glömts bort. Min avhandling är ett försök att lyfta fram en grupp manliga patienter och studera ett exempel på hur den manliga kroppen behandlats. ${ }^{740}$

Inommedicinska studier som den jag genomfört kan på detaljnivå lyfta fram sådant som större översiktliga studier missar. För någon som studerar till exempel hela 1800-talet är det lätt att bortse från en behandlingsform som kastrering för prostatahypertrofi, som användes under så kort tid. Men då missar man vad som låg bakom dessa behandlingar och hur läkare och kirurger resonerade kring dem, och utan den bakgrunden kan kastrering tyckas ha varit en behandlingsmetod som inte hade något större stöd och som övergavs av de få som använde den eftersom tidens inställning till den manliga kroppen var att de manliga könsorganen och framförallt testiklarna skulle lämnas ifred. Detta hävdar ju till exempel Sengoopta i sin översikt över endokrinologins historia mellan 1850 och 1950. Baserat på mer övergripande analyser av hur samhället i stort förhöll sig till kvinnor, män och deras kroppar nämner han kastrering för prostatahypertrofi kortfattat i en not som en avvikelse från normen att testiklarna lämnades ifred om det inte var sjukliga. ${ }^{741}$

Vad dessa översiktliga studier missar är att många läkares och kirurgers inställning - och jag har följt flera av de tongivande och framstående inom området - inte alls stämmer överens med denna bild. Kastrering som behandlingsmetod infördes för att det ansågs finnas teoretiska och kliniska

\footnotetext{
740 Även Sally Frampton har lyft fram Benninghaus kritik men fokuserat mer på osynliggörandet av kvinnliga patienters agens, Frampton 2018, s. 4.

741 Sengoopta 2006, s. $28-29$.
} 
underlag för att den skulle kunna fungera, och initialt togs metoden emot med entusiasm eftersom den förutspåddes kunna bota många patienter som annars led och i värsta fall dog. Att behandlingen övergavs hade delvis att göra med den övertygelse som växte fram om att testiklarna på något sätt påverkade det manliga psyket och att avlägsnandet av dem kunde ge en negativ påverkan. Men för många läkare och kirurger var det andra anledningar som var mer avgörande, huvudsakligen de dåliga kliniska resultaten. Det fungerade helt enkelt inte att bota prostatahypertrofi med kastrering.

\section{Kastreringens återkomst}

Några decennier senare kom manlig kastrering tillbaka som behandlingsmetod, denna gång mot cancer i prostatan. Charles B. Huggins publicerade 1941 en studie om hur androgener (manliga könshormoner) påverkade prostatacancer och att kastrering eller injektioner med östrogen därför fungerade som en framgångsrik bromsande behandling av metastaserad cancer i prostatan. ${ }^{742}$ Det ledde till att hormonbehandlingar och även kirurgisk kastrering började användas vid tidigare obotlig cancer i prostatan. Under 1960- till 1980-talet utvecklades och introducerades nya varianter av hormonbehandling, vilka fortfarande innebar en hormonell kastrering, som ett alternativ till kirurgisk kastration.743 År 1966 belönades Huggins med ett delat Nobelpris i medicin för sin upptäckt. ${ }^{744}$

${ }^{742}$ Charles Huggins \& Clarence V. Hodges, "Studies on Prostatic Cancer: I. The Effect of Castration, of Estrogen and of Androgen Injection on Serum Phosphatases in Metastatic Carcinoma of the Prostate" (Received for publication March 22, 1941), The fournal of Urology, vol. 168, nr. 1, juli 2002, s. $9-12$.

${ }^{743}$ Samuel R. Denmeade \& John T. Isaacs, ”A History of Prostate Cancer Treatment”, Nature Reviews Cancer, vol. 2, 2002, s. 389 - 396.

${ }^{744}$ Charles Huggins https://www.nobelprize.org/prizes/medicine/1966/huggins/facts/ [sidan besökt 2019-10-05] 
Ungefär trettio år efter att kastrering hade övergetts som botemedel mot prostatahypertrofi kom alltså behandlingen tillbaka för att bota prostatacancer, men nu främst i homonell form. Hormonell kastrering används än i dag. ${ }^{745}$ När behandlingen kom tillbaka byggde dock resonemanget på idén att testosteroner stimulerar cancertillväxten i prostatan, och de mer moderna formerna av kastrering innebär att man tillför östrogen eller blockerar de androgener som får cancern att växa. Även godartad prostataförstoring behandlas idag ibland med hormonblockerare som minskar bildandet av den aktiva formen av testosteron. ${ }^{746}$

Behandlingen av prostatahypertrofi under 1890-talet och den tidiga behandlingen av prostatacancer med kirurgisk kastrering under 1940-talet visar tydligt att testiklarna inte låg bortom läkare och kirurgers horisont när det gällde möjliga ingrepp och behandlingar av manliga patienter, även när det inte var just testiklarna som var drabbade av sjukdom. I likhet med Benninghaus och Darby och andra har jag i denna avhandling velat lyfta fram hur just delar av den manliga kroppen blev vetenskapliga objekt för medicinen att betrakta och behandla. Jag har också velat lyfta fram det faktum att mäns könsorgan, könskörtlar och även kroppar i övrigt inte var undantagna från de praktiska konsekvenserna av denna process.

${ }^{745}$ Se till exempel Howard I. Scher m.fl., "Design and End Points of Clinical Trials for Patients With Progressive Prostate Cancer and Castrate Levels of Testosterone:

Recommendations of the Prostate Cancer Clinical Trials Working Group”, Fournal of Clinical Oncology, vol. 26, nr. 7, 2008, s. $1148-1159$.

${ }^{746}$ Se till exempel Tacklind J, Fink HA, Macdonald R, Rutks I, Wilt TJ, ”Finasteride for benign prostatic hyperplasia", The Cochrane Database of Systematic Reviews, vol. 10, okt. 2010, s. $1465-1858$. 


\section{English summary}

At the end of the $19^{\text {th }}$ century a new treatment method for prostate hypertrophy was tried in Europe and North America: castration. The idea came from a perceived analogy between the female uterus and the male prostate, or between the diseases uterine myoma and prostate hypertrophy. This analogy was then reinforced by observations done on castration of animals and humans which had shown that the prostate atrophies when an animal or human is castrated and observations of the prostate in eunuchs which showed that the prostate did not develop if the testicles had been removed before puberty.

This will be explored in this dissertation through the theoretical lens of making and remaking of knowledge objects, and employing the theoretical framework of Karen Barad's agential realism together with some of Donna Haraway's theoretical concepts. Intra-action, agential cuts and how this produces a knowledge object possible to investigate scientifically is at the heart of the analysis. To support this, Haraway's concepts of situated knowledge and scientific story-telling are used to broaden the analysis, as well as the concept of a spectrum of killability, as developed by Tara Mehrabi.

In the first empirical chapter I develop the analysis of the prostate and prostate hypertrophy as knowledge objects. With Barad's agential realism I show how the prostate as an anatomical object through intra-action and agential cuts was separated from adjacent structures in the body and made into a scientific knowledge object. This intra-action was dependent on surgeons and their previous knowledge of the body, the apparatuses used (post mortem examinations, fingers, eyes, scalpels) and the prostate as a material object. In intra-action the prostate 
became a gland (one, not two and not a muscle) that produced a secretion that was part of men's ejaculations.

I also show how prostate hypertrophy as a disease was made through intraaction between surgeons, apparatuses and the symptoms and structural changes in the prostate. An important part in the making of prostate hypertrophy was the complex of symptoms and the fact that they were not exclusively connected to this disease. A part of the knowledge production of this disease was the exclusion of other possible causes. The etiology of prostate hypertrophy was never clarified during the period studied in this dissertation.

In the second empirical chapter I analyze the analogy behind the proposal of using castration as a treatment method for prostate hypertrophy. I show how women's bodies were used as a key to understanding the male body when knowledge was lacking. Both the explanation for the tumors in the prostate and the treatment method were more or less directly transferred from women to men. This analogy was heavily critiqued: physicians could not agree on which structures in the female and male body were actually analogous and it appeared as if the tumors developed from different kinds of tissue. Uterine myoma are fibroids, muscle tumors, and prostate hypertrophy was, by many, considered to be adenoma, that is, tumors developed in glandular tissue.

I also show how physicians and surgeons looked for other similarities and tried to find a male menopause. This would have strengthened the argument for castration since the connection between menopause and uterine myoma had shown that they atrophied or did not develop after menopause. Since castration seemed to make myoma atrophy, this was considered to be a way to initiate whatever process happen with the menopause, earlier. If the same period could be found in men's reproductive life, this would mean that the process in men's bodies could be started with castration as well. This chapter highlights how physicians and surgeons transferred the knowledge about the influence of ovaries on the uterus to the testicles and the prostate. 
In the third chapter, I show the importance played by men who deviated from the norm of two fully functioning testicles in knowledge production about the prostate. In intra-actions and entanglements of surgeons, apparatuses like post mortem, palpation and ocular inspection, and the bodies of men, knowledge about the "normal" male body was created. This knowledge production was focused on the effect of these different conditions on the prostate. Important knowledge about the influence on the development of the prostate during puberty and the influence of castration on grown men was made. These investigations also had the aim of showing that unilateral castration might work to cure prostate hypertrophy. If the connection between the testicles and the prostate could be shown to be so intimate that the corresponding half of the prostate would atrophy if the testicle was removed, this would be a strong argument for only removing one testicle. There were some observations that supported this theory, but not enough.

Animal experiments also played an important part in the knowledge production about prostate hypertrophy and in the fourth empirical chapter I detail the contributions from such experiments. Animals were chosen because of the similarities between their prostates and human prostates on a spectrum from "very humanlike" to "not humanlike at all". Additionally, animals in experiments were put on a spectrum of killability based on "enough like a human but still not" and "too much like a human", resulting in that primates were not used. Animals were also chosen because of their imminent killability, and as such the animal most commonly used for these experiments were dogs. Animal experiments show that the prostate atrophied after castration but there were some controversies over the transferability of these findings to humans.

In the following chapter I analyze the differences and similarities between female and male castration. By comparing my material to previous research on ovariotomy and female castration, I show that both female and male castration were controversial operations. Some physicians thought that it had the same negative effects on women and men, some thought the negative effects were 
exclusive to males. The most interesting finding is that female castration was used to treat mental health issues in women but was, by many, considered to cause mental health problems in men.

When these mental health problems were discovered, some physicians and surgeons recommended or tried injections with testiculi, an extract of animal testicles. The fact that hormones were not part of the explanation of how the testicles, or ovaries, influenced the body is an important part of the knowledge production during this period. Physicians could observe some kind of influence and speculated on theories about nerves, internal secretions and possible internal secretions transported by the nerves. I show how these different explanations had an effect on castration as a treatment method for prostate hypertrophy.

In the final empirical chapter, I analyze the abandonment of castration as a treatment method for prostate hypertrophy. I show how several different developments, uncertain results, the resistance of the patients, bad statistical results and the critique of the possibility of transferring results from animals to humans led to the cessation of the castration as a treatment method. I also discuss the importance of the development of other kinds of treatments that replaced castration. Catheterization became a much safer alternative when methods for cleaning catheters were developed, and different kinds of prostatectomy were developed, with improved results.

This study shows the importance of a more detailed approach to medical history. Male castration has been considered extremely unusual as a medical operation unless the testicles have been afflicted in some way. In this dissertation I have been able to show that many physicians and surgeons in the 1890s were actually not opposed to removing healthy testicles in males to treat prostate hypertrophy. The abandonment of the operation had more to do with other arguments than an underlying cultural respect for the testicles. Additionally, male castration reappeared in the 1940s to treat prostate cancer and is with us today in versions of hormonotherapy. 


\section{Referenser}

\section{Tidskrifter}

Annals of Surgery

Hygiea

Journal of Anatomy and Physiology

Nordiskt Medicinskt Arkiv

Norsk Magazin for Legervidenskaben

The British Medical fournal

The Lancet

University Medical Magazine

\section{Tryckta källor}

"An Epitome of Current Medical Literature", The British Medical Journal, vol. 2, nr. 1755, aug. 18, 1894, s. 25-28.

"An Epitome of Current Medical Literature", The British Medical Journal, vol. 1, nr. 1777, jan. 19, 1895a, s. 9-12

"An Epitome of Current Medical Literature", The British Medical Journal, vol. 2, nr. 1807, aug. 17, 1895b, s. 25-28.

"An Epitome of Current Medical Literature", The British Medical Fournal, vol. 2, nr. 1801, jul. 6, 1895c, s. 1-4.

"An Epitome of Current Medical Literature", The British Medical fournal, vol. 1, nr. 1828, jan. 11, 1896a, s. 5-8 
"An Epitome of Current Medical Literature", The British Medical Fournal, vol. 1, nr. 1842, apr. 18, 1896b, s. 61-64

"An Epitome Of Current Medical Literature", The British Medical Fournal, vol. 1, nr. 2476, jun. 13, 1908, s. 93-96.

Borelius, Jacques, "Om kastration vid prostatahypertrofi”, Hygiea, band 58, del 1, mars, 1896, s. 424-434.

Borelius, Jaques, "Bidrag till den s. k. prostatahypertrofiens patologi och terapi", Del 1, Hygiea, band 59, del 1, februari, 1897a, s. 223-288.

Borelius, Jaques, "Bidrag till den s.k. prostatahypertrofiens patologi och terapi", Del 2, Hygiea, band 59, del 1, juni, 1897b, s. 591-644.

Borelius, Jaques, "Bidrag till den s.k. prostatahypertrofiens patologi och terapi", Del 3, Hygiea, band 59, del 2, juli, 1897c, s. 1-46.

"British Medical Journal", The British Medical fournal, vol. 2, nr. 3110, aug. 7, 1920, s. 214-217.

Brownfield, H. M., "Castration for Prostatic Hypertrophy", The British Medical Fournal, vol. 1, nr. 1837, mar. 14, 1896, s. 657.

Buckston Browne, George, "Castration for Prostatic Hypertrophy", The British Medical fournal, vol. 1. nr. 1776, jan. 12, 1895, s. 110.

Buckston Browne, George, 'The Harveian Lecture on Twenty-Five Years' Experience of Urinary Surgery in England. Lecture II", The Lancet, vol. 158, nr. 
4082 (ursprungligen publicerad som volym 2, nr. 4082) nov. 23, 1901, s. 1395 1399.

Bäärnhielm, G., "Ett fall af perineal prostatektomi”, Hygiea, band 63, del 2, september, 1903, s. 219-226.

Cabot, Arthur Tracy, "The question of castration for enlarged prostate", Annals of Surgery, vol. 24, nr. 3, sep. 1896, s. 265 - 309.

Charlton, Frederick, "A Case of Castration for Prostatic Hypertrophy", The British Medical Fournal, vol. 1, nr. 1843, apr. 25, 1896, s. 1031-1032.

Clarke, Bruce W., "Prostatectomy In Two Stages, With An Account Of Seven Cases", The British Medical Fournal, vol. 2, nr. 2077, okt. 20, 1900, s. 1182-1184.

Clarke, Henry E., "The Effects of Unilateral Castration on the Prostate", The British Medical Fournal, vol. 1, nr. 1784, mar. 9, 1895, s. 563.

Daniel, P. L., "The Pathology Of Prostatic Enlargement", The British Medical Fournal, vol. 2, nr. 2287, okt. 29, 1904, s. 1140-1145.

Dittel, Leopold Rittel von, "Beiträge zur Lehre der Prostatahypertrofi", Medizinische Fahrbücher, band 13, Wien, 1867.

"Edinburgh Medico-Chirurgical Society", The Lancet, vol. 155, nr. 3903 (ursprungligen publicerad som volym 1, nr. 3903) juni 18, 1898, s. 1692.

Faulds, A. G., "Castration for Enlarged Prostate", The British Medical fournal, vol. 1, nr. 1792, maj 4, 1895, s. 974-975. 
Fenwick, Edwin Hurry "The Effects of Unilateral Castration on the Prostate", The British Medical Journal, vol. 1, nr. 1784, mars 9, 1895a, s. 529.

Fenwick, Edwin Hurry, "Observations on the Effects of Double Castration (White's Operation) Upon the Enlarged Prostate", The British Medical Fournal, vol. 1, nr. 1785, mars 16, 1895b, s. 578-579.

Fremont - Smith, F., "A Case of Obstructive Hypertrophy of the Prostate Treated by Castration", Annals of Surgery, vol. 20, 1894, s. 52-55.

Freyer, Peter Johnston, Clinical Lectures on Stricture of the Urethra and Hypertrophy of the Prostate, Baillière, Tindal, and Cox, London., 1901 a.

Freyer, Peter Johnston, "Two Clinical Lectures on Enlargement of the Prostate", The Lancet, vol. 157, nr. 4037 (ursprungligen publicerad som volym 1, nr. 4037) jan. 12, 1901b, s. 79-81.

Freyer, Peter Johnston, "Two Clinical Lectures on Enlargement of the Prostate", The Lancet, vol. 157, nr. 4038 (ursprungligen publicerad som volym 1, nr. 4038) jan. 19, 1901c, s. 149-156.

Freyer, Peter Johnston, "A Clinical Lecture On Total Extirpation Of The Prostate For Radical Cure Of Enlargement Of That Organ: With Four Successful Cases", The British Medical Journal, vol. 2, nr. 2116, jul. 20, 1901d, s. 125-129.

Freyer, Peter Johnston, "A Clinical Lecture On A Further Series Of Cases Of Total Extirpation Of The Prostate For Radical Cure Of Enlargement Of That Organ”, The British Medical fournal, vol. 1, nr. 2144, feb. 1, 1902, s. 249-254. 
Freyer, Peter Johnston, "A Clinical Lecture On A Fifth Series Of Cases Of Total Extirpation Of The Prostate For Radical Cure Of Enlargement Of That Organ”, The British Medical Fournal, vol. 1, nr. 2207, apr. 18, 1903, s. 898-901.

Freyer, Peter Johnston, "110 Cases or Total Enucleation of the Prostate for Radical Cure of Enlargement of that Organ”, The Lancet, vol. 164, nr. 4221 (ursprungligen publicerad som volym 2, nr. 4221) juli 23, 1904, s. 197-203.

Freyer, Peter Johnston, "A recent series of 212 cases of Total Enucleation of the Prostate, With Special Reference to Octogenarians", The British Medical Fournal, vol. 2, nr. 2544, okt. 22, 1909, s. 963-966.

Freyer, Peter Johnston, "One Thousand Cases of Total Enucleation of the Prostate for Radical Cure of Enlargement of that Organ", The British Medical fournal, vol. 2, nr. 2701, okt. 5, 1912, s. 868-870.

Fullerton, Andrew, "Note On A Series Of Fifty-Five Cases Of Suprapubic Prostatectomy, With Four Deaths", The British Medical Journal, vol. 1, nr. 2720, feb. 15, 1913, s. 332-335.

"Förhandlingar vid Svenska Läkaresällskapets sammankomster år 1843 - 1844. Den 24 Oktober 1843", Hygiea, band 6, december, 1844, s. 786-787.

Godard, Ernest, Études sur la Monorchidie et la cryptorchidie chez l'homme, Paris, 1857. Fulltext genom https://archive.org/stream/b22282543/b22282543_djvu.txt [sidan besökt 2017-10-17]

Griffiths, Joseph, "Observations on the anatomy of the prostate", Fournal of Anatomy and Physiology, vol. 23 (Pt3), april, 1889a, s. 374-386. 
Griffiths, Joseph, "Observations on the Function of the Prostate Gland in Man and the Lower animals", Fournal of Anatomy and Physiology, vol. 24 (Pt1), okt. 1889b, s. 27-41.

Griffiths, Joseph, "The Prostate Gland: Its Enlargement or Hypertrophy: Part III", Journal of Anatomy and Physiology, vol. 24 (Pt2), jan, 1890, s. 236-246.

Griffiths, Joseph, "Castration in the Enlargement of the Prostate", The British Medical Fournal, vol. 2, nr. 1709, sep. 30, 1893, s. 765.

Griffiths, Joseph, "The Condition of the Testes and Prostate Gland in Eunuchoid Persons", fournal of Anatomy and Physiology, vol. 28 (Pt2), jan. 1894, s. 221-227.

Griffiths, Joseph, "An Enlarged Prostate Gland Eighteen Days After Castration", The British Medical Fournal, vol. 1, nr. 1785, mars 16, 1895a, s. 579581.

Griffiths, Joseph, "Three Lectures Upon the Testes, Lecture I", The Lancet, vol. 145, nr. 3735 (ursprungligen publicerad som volym 1, nr. 3735) mars 30, 1895b, s. 791-794.

Griffiths, Joseph, "Three Lectures Upon the Testes, Lecture II", The Lancet, vol. 145, nr. 3735 (ursprungligen publicerad som volym 1, nr. 3735) mars 30, 1895c, s. 795-799.

Griffiths, Joseph, "Three Lectures Upon the Testes, Lecture III", The Lancet, vol. 145, nr. 3737 (ursprungligen publicerad som volym 1, nr. 3737) april 13, 1895d, s. $916-920$. 
Guyons, Jean Casimir Félix, Leçons cliniques sur les affections chirurgicales de la vessie et de la prostate, Paris : J.-B. Baillière, 1888.

Haeckel, Ernst Heinrich Philipp August, The History of Creation. Or the development of the Earth and its Inhabitants by the Action of Natural Causes, London, H. S. King \& Go. 1880.

Harrison, Reginald, "Lettsomian Lectures on some Points in the Surgery of the Urinary Organs", The British Medical Fournal, vol. 1, nr. 1412, jan. 21, 1888, s. 118-122.

Harrison, Reginald, "The Fibromatous Prostate", The British Medical Fournal, vol. 1, nr. 1464, jan. 19, 1889, s. 126.

Harrison, Reginald, "Castration in Enlargement of the prostate", The British Medical Fournal, vol. 2, nr. 1708, sep. 23, 1893, s. 708-709.

Harrison, Reginald, "Observations on the Pathology of Enlarged or Hypertrophied Prostate", The British Medical Fournal, vol. 2, nr. 1826, dec. 28, 1895, s. $1605-1608$.

Harrison, Reginald, "Clinical Remarks on Division of the Vas Deferens in Cases of Obstructive Prostatic Hypertrophy", The Lancet, vol. 147, nr. 3782 (ursprungligen publicerad som volym 1, nr. 3782) feb. 22, 1896a, s. 473-474.

Harrison, Reginald, "The Bradshaw Lecture on Vesical Stone and Prostatic Disorders", The Lancet, vol. 148, nr. 3824 (ursprungligen publicerad som volym 2, nr. 3824) dec. 12, 1896b, s. 1657-1662. 
Harrison, Reginald, "Remarks on the Surgery of the Vas Deferens Relative to Some Urinary Disorders", The Lancet, vol. 151, nr. 3880 (ursprungligen publicerad som volym 1, nr. 3880 ) jan. 8, 1898, s. 94-95.

Harrison, Reginald, "On some Structural Varieties of the Enlarged Prostate Relative to its Treatment", The Lancet, vol. 154, nr. 3962 (ursprungligen publicerad som volym 2, nr. 3962) aug. 5, 1899, s. $331-332$.

Harrison, Reginald, "Remarks on Vasectomy Relative to Enlarged Prostate and Bladder Atony", The Lancet, vol. 155, nr. 4001 (ursprungligen publicerad som volym 1, nr. 4001) maj 5, 1900, s. 1275-1276.

Harvey, William Exercitatio Anatomica de Motu Cordis et Sanguinis in Animalibus, Francofurti: Fitzer, 1628.

Herring, Herbert T., "The Relative Advantages Of Catheterization And Operation In The Treatment Of Prostatic Enlargement", The British Medical Fournal, vol. 2, nr. 2533, jul. 17, 1909, s. 136-138.

Hunt, Arthur, "Hypertrophy of the Prostate; Severe Cystitis; Double Castration; Recovery", The Lancet, vol. 148, nr. 3814 (ursprungligen publicerad som volym 2, nr. 3814) okt. 3, 1896, s. 939-940.

Hunter, John, Observations on Certain Parts of the Animal Oeconomy, andra upplagan, London, 1792, s. 1-20. Fulltext genom https://archive.org/details/observationsonce1792hunt [sidan besökt 2019-1017]

Iversen, Axel Hypertrophia Prostate, Kjøbenhavn Gad, 1874. 
Jennings, Charles E., "Castration for Prostatic Hypertrophy", The British Medical Fournal, vol.1, nr. 1777, jan. 19, 1895, s. 171.

Kendall, H. W. M., "Castration in Enlarged Prostate", The British Medical Fournal, vol. 2, nr. 1813, sep. 28, 1895, s. 779.

"Kidderminster Medical Society", The Lancet, vol. 145, nr. 3731 (ursprungligen publicerad som volym 1, nr. 3731) mars 2, 1895, s. 549-551.

Lanouis, Pierre-Émile, "De l'Atrophie de la prostate, de la castration dans l'hypertrophie de la prostate ; étude embryologique, tératologique, anatomique, clinique et expérimentale", Annales des Maladies des Organes génito-urinaire, oktober, 1894, s. 7-47.

MacEwan, David, Harrison, Reginald, Mansell Moullin Charles William, Dr. Sandberg, Chiene, John, Southam, F. A., Morton, Charles A., Jordan J., Haddon and Cameron, J. H., "Discussion On The Surgical Treatment Of Prostatic Hypertrophy", The British Medical Fournal, vol. 2, nr. 1867, okt. 10, 1896, s. 989-996.

Maclaren, Roderick, "Address In Surgery. On Preventive Surgery", The British Medical Fournal, vol. 2, nr. 1857, aug. 1, 1896, s. 259-264.

MacMunn, James, "The Functions of the Prostate", The British Medical Fournal, vol. 2, nr. 1649, aug. 6, 1892, s. 328.

MacMunn, James, "Castration in Enlargement of the prostate", The British Medical Fournal, vol. 2, nr. 1708, sep. 23, 1893, s. 709. 
MacMunn, James, "Castration for Prostatic Hypertrophy", The British Medical Gournal, vol. 1, nr. 1776, jan. 12, 1895, s. 110

Mansell Moullin, Charles William, "Lectures on the Operative Treatment of Enlargement of the Prostate", The Lancet, vol. 139, nr. 3588 (ursprungligen publicerad som volym 1, nr. 3588) juni 4, 1892a, s. 1229-1231.

Mansell Moullin, Charles William, "Lectures on the Operative Treatment of Enlargement of the Prostate", The Lancet, vol. 139, nr. 3589 (ursprungligen publicerad som volym 1, nr. 3589) juni 11, 1892b, s. 1287-1289.

Mansell Moullin, Charles William, "Castration in Enlargement of the Prostate" The British Medical Fournal, vol. 2, nr. 1707, sep. 16, 1893a, s. 655.

Mansell Moullin, Charles William, "Castration in Enlergement of the Prostate" The British Medical Fournal, vol. 2, nr. 1709, sep. 30, 1893b, s. 765.

Mansell Moullin, Charles William, Enlargement of the Prostate, 1894a.

Mansell Moullin, Charles William, "The Pathology of enlargement of the prostate", The Lancet, vol. 144, nr. 3712 (ursprungligen publicerad som volym 2, nr. 3712 ) okt. 20, 1894b, s. 908-909.

Mansell Moullin, Charles William, "On the Treatment of Enlargement of the Prostate by Removal of the Testes", The British Medical Journal, vol. 2, nr. 1766, nov. 3, 1894c, s. 976.

Mansell Moullin, Charles William, "Castration for Prostatic Hypertrophy", The British Medical Fournal, vol. 1. nr. 1776, jan. 12, 1895a, s. 110. 
Mansell Moullin, Charles William, "Castration for Prostatic Hypertrophy", The British Medical Fournal, vol.1. nr. 1777, jan. 19, 1895b, s. 171.

Mansell Moullin, Charles William, "Castration for Enlarged Prostate", The British Medical fournal, vol. 1, nr. 1793, maj 11, 1895c, s. 1064-1065.

Mansell Moullin, Charles William, "The Effects of Unilateral Castration on the Prostate", The British Medical Fournal, vol. 1, nr. 1788, apr. 6, 1895d, s. 786-787.

Mansell Moullin, Charles William, "On Some of the Immediate Results Produced by Castration in Cases of Enlarged Prostate", The Lancet, vol 146, nr. 3770 (ursprungligen publicerad som volym 2, nr. 3770) nov. 30, 1895e, s. 13471348.

Mansell Moullin, Charles William, "The Pathology of Enlargement of the Prostate", The British Medical Fournal, vol. 1, nr. 1828, jan. 11, 1896a, s. 114-115.

Mansell Moullin, Charles William, "Unilateral Orchotomy for Enlargement of the Prostate", The Lancet, vol. 147, nr. 3779 (ursprungligen publicerad som volym 1, nr. 3779) feb. 1, 1896b, s. 288.

Mansell Moullin, Charles William, "Some of the Recent Results of Orchotomy for Enlarged Prostate", The Lancet, vol. 147, nr. 3780 (ursprungligen publicerad som volym 1, nr. 3780) feb. 8, 1896c, s. 348-350.

Mansell Moullin, Charles William, Enlargement of the Prostate. Its Treatment and Radical Cure, London H K. Lewis, Tredje utgåvan, 1904.

Massa, Niccolò, Liber Introductorius Anatomiae, Venetiis: Bindonus, 1536. 
Massa, Niccolò, De Humani Corporis Fabricia, Basiliea: Ex officina Joannis Oporini, 1543.

"Medical News. Harveian Society", The Lancet, vol. 149, nr. 3841 (ursprungligen publicerad som volym 1, nr. 3841) april 10, 1897, s. 1060-1063.

"Medical Society of London", The Lancet, vol. 155, nr. 3994 (ursprungligen publicerad som volym 1, nr. 3994) mars 17, 1900, s. 774-776.

Mercier, Louis Auguste, "Om ett nytt medel att med säkerhet diagnostisera Prostatæ olika deformationer, hvilka blifvit ansedda som vanliga orsaker till retentio et incontinentia urinæ hos äldre männer, af D:r A. Mercier; öfvers. af J. Hörlin (Neue Notizen etc. v. v. Froriep N:o 231, 1839)", Hygiea, band 2, juni, 1840, s. 274-281.

Meyer, Willy, "Simultaneous Ligation of Both Internal Iliac Arteries for Hypertrophy of the Prostate Gland", Annals of Surgery, vol. 20, juli, 1894, s. 4451.

Morris, Henry, "An address On The Study Of Anatomy", The British Medical Journal, vol. 2, nr. 1822, nov. 30, 1895, s. 1337-1342.

Moszkowiez, L. \& Stegmann, R., ’Die Behandlung der Prostata-hypertophie mit Röntgenstrahlen", Münchener med. Wochenschrift, 1905, s. 1390. Översatt i Hygiea, band 67, del 2, november, 1905, s. 1226 - 1228.

Motz, Boleslas, Contribution á l'étude de la structure histologique de l'hypertrophie de la Prostate: introduction au traitement de l'hypertrophie de la prostate par les opérations sur l'appareil testiculaire, (Thèse de Paris), Paris: Henri Jouve, 1896. 
Nicoll, Jas. H., "A Method of Excising the Prostate", The Lancet, vol. 143, nr. 3685 (ursprungligen publicerad som volym 1, nr. 3685) april 14, 1894, s. 926927.

Nicoll, James H., "The Treatment of Chronic Enlargement of the Prostate", The British Medical Fournal, vol. 2, nr. 1974, okt. 29, 1898, s. 1314-1316.

"Nordiska kirurgiska föreningens andra möte i Christiania den 11-13 juli 1895." Refererat av Anders Hansson, Hygiea, band 57, del 2, augusti, 1895, s. 171-172.

"Nordiska kirurgiska föreningens tredje möte i Helsingfors den 12-14 augusti 1897." Refererat av Anders Hansson, Hygiea, band 59, oktober, 1897, s. 389394.

"Obituary", The Lancet, vol. 198, nr. 5117 (ursprungligen publicerad som volym 2, Issue 5117) sep. 24, 1921, s. 677-678.

"Pathological Society of London", The Lancet, vol. 164, nr. 4234 (ursprungligen publicerad som volym 2, nr. 4234) okt. 22, 1904, s. 1150-1152.

"PARIS.", The Lancet, vol. 144, nr. 3704 (ursprungligen publicerad som volym 2, nr. 3704) aug. 25, 1894, s. 468.

Paul, F. T., "The Pathology of Prostatic Enlargement", The Lancet, vol. 176, nr. 4535 (ursprungligen publicerad som volym 2, nr. 4535) juli 30, 1910, s. 294-297.

Picard, Henri, Traité des Maladies de la Prostate et des vésicules séminales, Paris: G. Carré, 1896. 
Powell, Arthur, "Atropy of Prostate After Castration", The British Medical Fournal, vol. 2, nr. 1716, nov. 18, 1893, s. 1099

"Prospects in Genito-Urinary Surgery", The Lancet, vol. 157, nr. 4056 (ursprungligen publicerad som volym 1, nr. 4056) maj 25, 1901, s. 1487.

Ramm, Fredrik, "Kastration for prostatahypertrofi", Nordiskt Medicinskt Arkiv, N:r 29, Årg. 1895.

Ramm, Fredrik, "Kastration ved Prostatahypertrofi", tilläggsskrift till Norsk Magazin for Lagervidenskaben, maj, 1896, Kristiania Det Steenske Bogtrykkeri 1896.

"Reginald Harrison, Fr. C. S. Eng", The British Medical Fournal, vol. 1, nr. 2462, mar. 7, 1908, s. 601-603.

Remondino, P. C., "The Effects of Unilateral Castration on the Prostate", The British Medical Fournal, vol. 1, nr. 1788, apr. 6, 1895, s. 786.

"Reviews and Notices of Books", The Lancet, vol. 146, nr. 3770 (ursprungligen publicerad som volym 2, nr. 3770) Nov. 30, 1895, s. 1369-1370.

"Reviews and Notices of Books", The Lancet, vol 154, nr. 3976 (ursprungligen publicerad som volym 2, nr. 3976) nov. 11, 1899, s. 1303-1305.

"Reviews and notices of Books", The Lancet, vol. 161, nr. 4164 (ursprungligen publicerad som volym 1, nr. 4164) juni 20, 1903, s. 1744-1746. 
Rissler, John, "Några fall af prostatahypertrofi behandlade med kastration eller resektion af vas deferens", Hygiea, band 58, december, 1896, s. 662-673.

"Sir Henry Thompson, Bart., M.B., F.R.C.S", The British Medical Fournal, vol. 1. nr. 2260, april 23, 1904, s. 991-993.

"Sjuk-Förslag från Kongl. Allm. Garnizons-Sjukhuset för året 1843 af D:r V. Lundberg. Anmärkningar för Chirurgiska Afdelningen.”, Hygiea, band 6, augusti, 1844, s. 531-532.

Socin, August, "Erkrankungen der Prostata", Chirurgie Band III. Erlangen 1873.

"Surgery", The Lancet, vol. 162, nr. 4191 (ursprungligen publicerad som volym 2, nr. 4191) dec. 26, 1903, s. 1792.

Swain, James, "Castration for Prostatic Hypertrophy", The British Medical Fournal, vol. 1, nr. 1775, jan. 5, 1895, s. 12-13

Syms, Parker, "Perineal Prostatectomy By a Special Method" del i Peter Johnston Freyer, Professor Alexander, W. Macewen, Jordan Lloyd, Parker Syms and Reginald Harrison "A Discussion On The Treatment Of Chronic Enlargement Of The Prostate", The British Medical Fournal, vol. 2, nr. 2184, nov. 8, 1902, s. 1492-1500.

"The Lancet: London: Saturday, December 28, 1895", The Lancet, vol. 146, nr. 3774, (ursprungligen publicerad som volym 2, nr. 3774) dec. 28, 1895, s. 16281658. 
"The Lancet,: London: Saturday, November 13, 1897", The Lancet, vol. 150, nr. 3872 (ursprungligen publicerad som volym 2, nr. 3872) nov. 13, 1897, s. 12581260

"The Seventh Congress of Scandinavian Surgeons,: From Our Own Correspondent", The Lancet, vol. 170, nr. 4386 (ursprungligen publicerad som volym 2, nr. 4386) sep. 21, 1907, s. 862-863.

"The structure and function of the prostate gland", The Lancet, vol. 154, nr. 3978 (ursprungligen publicerad som volym 2, nr. 3978) nov. 25, 1899, s. 1455.

Thompson, Henry,"Henry Thompson: Om de kirurgiska medel, som kunna användas för att giva lindring åt patienter med långt framskriden affektion af prostata", Hygiea, band 37, februari, 1875, s. 94-96.

Thompson, Henry, The Diseases of the Prostate, their pathology and treatment; comprising the second edition of "The Enlarged Prostate," and a dissertation "On the healthy and morbid anatomy of the prostate gland," to which the Facksonian prize for the year 1860, was awarded by the Royal College of Surgeons of England, sjätte upplagan, London: J. \& A. Churchill, 1886.

Thomson-Walker, John, "Enlarged Prostate And Prostatectomy", The British Medical Fournal, vol. 1, nr. 3608, mar. 1, 1930, s. 402-403.

"Underrättelser om medicinens viktigare framsteg i utlandet. Praktiska notiser. af prof. P. E. Gellerstedt.”, Hygiea, band 13, januari, 1851, s. 43-44. 
"Utdrag ur Embetsrapporter till K. Sundhets-kollegium. Abscessus Prostate. Rapport från Provincialläkare A. Beckman. (Gefleborgs län. Alfta distrikt.)", Hygiea, band 28, augusti, 1866, s. 321-322.

Wallace, Cuthbert, "A Review Of The Present Position Of Knowledge As To Prostatic Enlargement", The British Medical Journal, vol. 2, nr. 3489, nov. 19, 1927, s. 907.

Wallace, David, "An Adress in Tumors of the Bladder and Enlarged prostate", The Lancet, vol. 158, nr. 4063 (ursprungligen publicerad som volym 2, nr. 4063) july 13, 1901, s. 65-67.

Warholm, Richard, "Om prostatahypertrofiens operativa behandling", Hygiea, band 57, april, 1895, s. 403-114.

Webber, H. W., "Orchotomy for Enlarged Prostate", The British Medical Fournal, vol. 1, nr. 1833, feb. 15, 1896, s. 400.

White, William, "The Present Position of the Surgery of the Hypertrophied Prostate", Annals of Surgery, vol. 18, juli/december, 1893, s. 152-188.

White, William, "Castration as a Treatment for Hypertrophied Prostate", The British Medical fournal, vol. 1, nr. 1775, jan. 5, 1895a, s. 50.

White, Willian, "Castration for Prostatic Hypertophy", The British Medical Fournal, vol. 1, nr. 1782, feb. 23, 1895b, p. 448

White, William, "Effects of Unilateral Castration on the Prostate", The British Medical Fournal, vol. 1, nr. 1783, mar. 2, 1895c, s. 508. 
White, William, "Effects of Unilateral Castration on the Prostate", Annals of Surgery, vol. 21, 1895c, s. 492.

White, William, "The results of double castration in hypertrophy of the prostate”, Annals of Surgery, vol. 22, 1895d, s. 1-80.

White, William, "Castration and vasectomy in hypertrophy of the prostate", University Medical Magazine, april, 1897, s. 469-479.

"Årsberättelse för arbetsåret 1897-1898. Förhandlingar vid Svenska LäkareSällskapets sammankomster år 1898”, Hygiea, band 60, del 2, 1898, s. 128-130.

\section{Tryckt litteratur}

Arabatzis, Theodore, "On the Historicity of Scientific Objects", Erkenn, vol. 75, 2011, s. 377-390.

Barad, Karen Michelle, Meeting the Universe Halfway: Quantum Physics and the Entanglement of Matter and Meaning, Duke University Press, Durham, N.C., 2007.

Barad, Karen Michelle, "Posthumanist Performativity: Toward an Understanding of How Matter Comes to Matter", Signs: Fournal of Women in Culture and Society, vol. 28, nr. 3, 2003, s. $801-831$.

Barker-Benfield, Ben, "The Spermatic Economy: A Nineteenth Century View of Sexuality", Feminist Studies, vol. 1, nr. 1, sommer, 1972, s. 45-74

Bayuk Rosenman, Ellen, "Body Doubles: The Spermatorrhea Panic", Fournal of the History of Sexuality, vol. 12, nr. 3, juli, 2003, s. 365-399. 
Benninghaus, Christina, "Beyond Constructivism?: Gender, Medicine and the Early History of Sperm Analysis, Germany 1870-1900”, Gender \& History, vol.24 nr. 3, november, 2012, s. 647-676.

Bommenel, Elin, Sockerförsöket: kariesexperimenten 1943-1960 på Vipeholms sjukhus för sinnesslöa, (Diss.) Arkiv, Lund, 2006.

Bondestam, Maja, Tvåkönad. Studier i den svenska hermafroditens historia, Bokförlaget Nya Doxa, 2010.

Borell, Merriley, "Brown-Séquard's Organotherapy and its Appearance in America at the End of the Nineteenth Century", Bulletin of the History of Medicine, vol. 50, 1976, s. 309-320.

Braunmühl, Caroline, "Beyond hierarchical oppositions: A feminist critique of Karen Barad's agential realism", Feminist Theory, vol. 19, nr. 2, 2018, s. 223-240.

Brieger, Gert H., "From Conservative to Radical Surgery in Late Nineteenthcentury America" Christopher Lawrence (red.), Medical theory, surgical practice: studies in the history of surgery, Routledge, London, 1992, s. 216-231.

Brock, Clair, "Risk, Responsibility and Surgery in the 1890s and Early 1900s", Medical History, vol. 57, nr. 3, 2013, s. 317-337.

Brock, Clair, British Women Surgeons and Their Patients, 1860-1918, Cambridge: Cambridge University Press 2017. 
Bryant, Thomas, "Sexological Deliberation and Social Engineering: Albert Moll and the Sterilisation Debate in Late Imperial and Weimar Germany", Medical History, vol. 56, nr. 2, 2012, s. 237-254.

Bynum, W. F, Science and the Practice of Medicine in the Nineteenth Century, Cambridge Univ. Press, Cambridge, 1994.

Chapman, Allan, Physicians, plagues and progress: the history of western medicine from antiquity to antibiotics, Lion, Oxford, 2016.

Clift, Dean \& Schuh, Melina, "Restarting life: fertilization and the transition from meiosis to mitosis", Nature Reviewes Molecular Cell Biology, vol. 14, 2013, s. 549-562.

Cooper Owens, Deirdre, Medical Bondage: Race, Gender, and the Origins of American Gynecology, Athens: university of Georgia Press, 2017

Cryle, Peter, "Vaginismus: A Franco-American Story", fournal of the History of Medicine and Allied Sciences, vol. 67, nr. 1, 2010, s. 71-93.

Dale, Melissa S., "Understanding Emasculation: Western Medical Perspectives on Chinese Eunuchs", Social History of Medicine, vol. 23, nr. 1, 2010, s. 38-55.

Dally, Ann, Women under the knife: a history of surgery, Hutchinson Radius, London, 1991.

Dally, Ann, Fantasy Surgery, 1880-1930: With Special Reference to Sir William Arbuthnot Lane, Rodopi, Amsterdam, 1996. 
Daston, Lorraine, (red.), Biographies of scientific objects, University of Chicago Press, Chicago, Ill., 2000.

Darby, Robert, "William Acton's Antipodean Disciples: A Colonial Perspective on His Theories of Male Sexual (Dys)Function", Gournal of the History of Sexuality, vol. 13, nr. 2, apr., 2004, s. 157-182.

Darby, Robert, A Surgical Temptation. The Demonization of the Foreskin and the Rise of Circumcision in Britain, University of Chicago Press, 2005a.

Darby, Robert "Pathologizing Male Sexuality: Lallemand, Spermatorrhea, and the Rise of Circumcision", Journal of the History of Medicine and Allied Sciences, vol. 60, nr. 3, 2005b, s. $283-319$.

Denmeade, Samuel R. \& Isaacs, John T., "A History of Prostate Cancer Treatment", Nature Reviewes Cancer, vol. 2, 2002, s. 389-396.

Domurat Dreger, Alice, Hermaphrodites and the Medical Invention of Sex [Elektronisk resurs], Harvard University Press, 2000. ProQuest Ebook Central, https://ebookcentral.proquest.com/lib/linkoping-ebooks/detail.action?docID $=3300278$, 1998. [sidan besökt 2019-10-19]

Drakman, Annelie, När kroppen slöt sig och blev fast: varför åderlåtning, miasmateori och klimatmedicin övergavs vid 1800-talets mitt, (Diss.) Uppsala: Uppsala universitet, 2018.

Dwyer-Hemmings, Louis, "'A Wicked Operation?' Tonsillectomy in TwentiethCentury Britain”, Medical History, vol. 62, nr. 2, 2018, s. 217-241. 
Dyck, Erika \& Stewart, Larry (red.), The Uses of Humans in Experiment: Perspectives from the 17th to the 20th Century, Brill, Leiden, 2016.

Ekenstam, Claes, Kroppens idéhistoria: disciplinering och karaktärsdaning i Sverige 17001950, (Diss.) Gidlund, Hedemora, 1993.

Engelsgjerd JS, Deibert CM. Cystoscopy. [Updated 2019 Jul 16]. In: StatPearls [Internet]. Treasure Island (FL): StatPearls Publishing; 2019 Jan-. Available from: https://www.ncbi.nlm.nih.gov/books/NBK493180/ [sidan besökt 201910-17]

Fausto-Sterling, Anne, Sexing the body: gender politics and the construction of sexuality, 1. ed., Basic Books, New York, 2000.

Foucault, Michel, Diskursens ordning: installationsföreläsning vid Collège de France den 2 december 1970, Brutus Östlings bokförlag Symposion, Stockholm, 1993.

Franco, Nuno Henrique, "Animal Experiments in Biomedical Research: A Historical Perspective", Animals, vol. 3, nr. 1, 2013, s. 238-273.

Frampton, Sally, Belly-Rippers, Surgical Innovation and the Ovariotomy Controversy [Elektronisk resurs], Springer International Publishing, 2018.

Granshaw, Lindsay, "Knowledge of Bodies or Bodies of Knowledge? Surgeons, anatomists and rectal surgery, 1830-1985" Christopher Lawrence (red.), Medical theory, surgical practice: studies in the history of surgery, Routledge, London, 1992. 
Grob, Gerald, "The rise and decline of Tonsillectomy in Twentieth-Century America", Journal of the History of Medicine and Allied Sciences, vol. 62, nr. 4, 2007, s 383-421.

Guerrini, Anita, Experimenting with humans and animals: From Galen to animal rights, Baltimore: The Johns Hopkins University Press, 2003.

Gunnarsson, Lena, "The naturalistic turn in feminist theory: A Marxist-realist contribution", Feminist Theory, vol. 14, nr. 1, 2013, s. 3-19.

Haraway, Donna Jeanne, "Situated Knowledges: The Science Question in Feminism and the Privilege of Partial Perspective", Feminist Studies, vol. 14, nr. 3, hösten, 1988, s. 575-599.

Haraway, Donna Jeanne, Primate visions: gender, race and nature in the world of modern science, Verso, London, 1992[1989].

Haraway, Donna Jeanne, Modest_Witness@SSecond_Millennium.FemaleMan $\mathbb{C} \_$Meets __oncoMouse: feminism and technoscience, Routledge, New York, 1997.

Herr, HW, "Max Nitze, the cystoscope and urology", fournal of Urology, vol. 176, nr. 4, Oct., 2006, s. 1313-1316.

Hopwood, Nick, Embryos in wax. Models from the Ziegler studio, Cambridge: Whipple Museum of the History of Science, andra rättade upplagan, 2013.

Huggins, Charles \& Hodges, Clarence V., "Studies on Prostatic Cancer: I. The Effect of Castration, of Estrogen and of Androgen Injection on Serum Phosphatases in Metastatic Carcinoma of the Prostate" (Received for 
publication March 22, 1941), The Fournal of Urology, vol. 168, nr. 1, juli 2002, s. 912.

Jagger, Gill, "The New Materialism and Sexual Difference", Signs: Fournal of Women in Culture and Society, vol. 40, nr. 2, 2015, s. 321-342.

Johannisson, Karin, Den mörka kontinenten: Kvinnan, Medicinen och Fin-De-Siècle, Stockholm. Norstedt, 1995.

Johannisson, Karin, Medicinens öga: sjukdom, medicin och samhälle - historiska erfarenheter, [Ny utg.] Norstedt, Stockholm, 2013.

Jordanova, Ludmila. J., Nature displayed: gender, science, and medicine 1760-1820: essays, Longman, London, 1999.

Langlan, Robert C., "Benign Prostate Hyperplasia", Primary Care: Clinics in Office Practice, vol. 46, nr. 2, juni 2019, s. 223-232.

Larsson (Bondestam), Maja, Den moraliska kroppen: tolkningar av kön och individualitet $i$ 1800-talets populärmedicin, (Diss.) Gidlund, Hedemora, 2002.

Laqueur, Thomas, Making Sex: Body and Gender from the Greeks to Freud, Harvard University Press, Cambridge, Mass., 1992.

Lawrence, Christopher, "Democratic, Divine and Heroic: The History and Historiography of Surgery", Medical Theory, Surgical Practice, ed. Christopher Lawrence, London: Routledge, 1992. 
Lederer, Susan E., Subjected to Science: Human Experimentation in America Before the Second World War, Baltimore: Johns Hopkins University Press, 1995.

Mak, Geertje, Doubting sex. Inscriptions, bodies and selves in nineteenth-century hermaphrodite case histories, Manchester University Press, 2012.

Mak, Geertje, "Conflicting Heterosexualities: Hermaphroditism and the emergence of surgery around 1900", Journal of the History of Sexuality, vol. 24, nr. 3, september, 2015, s. $402-427$.

Marx, Franz Josef \& Karenberg, Axel, "History of the Term Prostate", The Prostate, vol. 69, nr. 2, 2009, s. $208-213$.

Matta, Christina, "Ambiguous Bodies and Deviant Sexualities: hermaphrodites, homosexuality, and surgery in the United States, 1850-1904", Perspectives in Biology and Medicine, vol. 48, nr. 1, vintern 2005, s. 74-83.

M'Charek, Amade, "Beyond Fact or Fiction: On the Materiality of Race in Practice", Cultural Anthropology, vol. 28, nr. 3, 2013, s. 420-442.

McLaren, Angus, Impotence: a cultural history, University of Chicago Press, Chicago, 2007.

Medvei, Viktor Cornelius, The history of clinical endocrinology: a comprehensive account of endocrinology from earliest times to the present day, Parthenon Pub. Group, Carnforth, Lancs., UK, 1993 
Mehrabi, Tara, Making Death Matter: A Feminist Technoscience Study of Alzheimer's Sciences in the Laboratory, Linköping University, Department of Thematic Studies, (Diss.) Linköpings universitet, 2016.

Micale, Mark S., Hysterical Men: Hidden History of Male Nervous Illness, Harvard University Press, 2008.

Morantz-Sanchez, Regina, Conduct Unbecoming of a Woman: Medicine on Trial in Turn-of-the-century Brooklyn, Oxford: Oxford University Press, 1999.

Moscucci, Ornella, The science of woman: gynaecology and gender in England, 18001929, Cambridge University Press, Cambridge, 1990.

Nilsson, Ulrika, Kampen om kvinnan: professionalisering och konstruktioner av kön $i$ svensk gynekologi 1860-1925, Institutionen för idé- och lärdomshistoria, (Diss.) Uppsala universitet, 2003.

O'Connor, Walter John, British Physiologists 1885-1914: A Biographical Dictionary, Manchester University Press, 1991.

O'Neill, Timothy, The Invisible Man? Problematising Gender and Male Medicine in Britain and America, 1800-1950, (Diss.) Center for the History of Science, Technology and Medicine, University of Manchester, 2003.

O'Shea, Christopher David, Visions of Masculinity: Home-health Advice Literature, Medical Discourse and Male Sexuality in English-Canada, 1870-1914, (Diss.) University of Guelph, Ottawa: National Library of Canada, 2003. 
O'Shea, Christopher David, "'A Plea for the Prostate': Doctors, Prostate Dysfunction, and Male Sexuality in Late $19^{\text {th }}$ - and Early $20^{\text {th }}$ - Century Canada", Canadian Bulletin of Medical History, vol. 29, nr. 1, vår 2012, s. 7-27.

Park, Katharine \& Nye, Robert, "Destiny is anatomy [Review of: Making sex: Body and Gender from the Greeks to Freud", The New Republic: A Journal of Politics and the Arts, vol. 18, 1991, s. 53-57.

Reis, Elisabeth, Bodies in Doubt. An American History of Intersex, The Johns Hopkins University Press. Baltimore, 2009.

Reusch, Kathryn, "That which was missing": the archaeology of castration, (Diss.)

Oxford university, UK, 2013. Tillgänglig genom:

https://ora.ox.ac.uk/objects/uuid:b81 18fe7-67cb-4610-9823-b0242dfe900a

[sidan besökt 2019-10-17]

Reverby, Susan M., Examining Tuskegee: the infamous syphilis study and its legacy, University of North Carolina Press, Chapel Hill, 2009.

Rutkow, Ira M., "Moments in Surgical History. Willy Meyer's Radical Mastectomy", The archoves of Surgery, vol.132, nr. 12, dec. 1997, s. 1362.

Scher, Howard I. m.fl., "Design and End Points of Clinical Trials for Patients With Progressive Prostate Cancer and Castrate Levels of Testosterone: Recommendations of the Prostate Cancer Clinical Trials Working Group”, Fournal of Clinical Oncology, vol. 26, nr. 7, 2008, s. 1148-1159.

Schiebinger, Londa, The Mind has no Sex?: Women in the Origins of Modern Science, Harvard University Press, 1991. 
Schlich, Thomas, "Changing Disease Identities: Cretinism, Politics and Surgery (1844-1892)", Medical History, vol. 38, nr. 4, 1994, s. 421-443.

Schlich, Thomas, "The Emergence of Modern Surgery", ed. Deborah Brunton, Milton Keynes, Medicine Transformed, Health, Disease and Society in Europe 18001930, UK: Open University Press, 2004.

Schlich, Thomas, The origins of organ transplantation: surgery and laboratory science, 1880-1930, University of Rochester Press, Rochester, NY, 2010.

Schlich, Thomas, "'One and the Same the World Over': The International Culture of Surgical Exchange in an Age of Globalization, 1870-1914", Fournal of the History of Medicine and Allied Sciences, vol. 71, nr. 3, 2016, s. 247-270.

Schlich, Thomas, "'Physiological surgery'. Laboratory Science as the Epistemic Basis of Modern Surgery (and Neurosurgery)", Casper, Stephen T. \& Gavrus, Delia (red.), The history of the brain and mind sciences: technique, technology, therapy, University of Rochester Press, Rochester, 2017.

Sengoopta, Chandak, The Most Secret Quintessence Of Life : Sex, Glands, And Hormones, 1850-1950, Chicago: University of Chicago Press, 2006.

Shackley, D. "A centrury of prostatic surgery", BfU International, vol. 83, nr. 7, 1999, s. 776-782.

Shelley, Harry "The Enlarged Prostate. A brief history of its treatment", Fournal of the History of Medicine and Allied Sciences, vol. 24, nr. 4, 1969, s. 452-473. 
Shorter, Edward, From paralysis to fatigue: a history of psychosomatic illness in the modern era, Free Press, New York, 1992.

Showalter, Elaine, Hystories: hysterical epidemics and modern culture, Columbia Univ. Press, New York, 1997.

Siegel Watkins, Elizabeth "Medicine, Masculinity, and the Disappearance of Male Menopause in the 1950s", Social History of Medicine, vol. 21, nr. 2, 2008, s. 329-344.

Stanley, Peter, For Fear of Pain: British Surgery, 1790-1850, Amsterdam and New York: Editions Rodopi, 2003.

States, Suzanne \& Marks, Lara, "Women's Trials: The Approval of the First Oral Contraceptive Pill in the United States and Britain", Oxford university Press, vol 57, 2002, s. $117-160$.

Stephens, Elizabeth, "Pathologizing Leaky Male Bodies. Spermatorrhea in Nineteenth - Century British Medicine and Popular Anatomical Museums", Fournal of the History of Sexuality, vol. 17, nr. 3, september 2008, s. 421-438.

Stolberg, Michael, "Self-pollution, moral reform and the veneral trade: Notes on the sources and historical context of Onania", fournal of the History of sexuality, vol. 9, nr. 1-2, jan/april, 2000, s. 37-61.

Stolberg, Michael, "A Woman Down to Her Bones: The Anatomy of Sexual Difference in the Sixteenth and Early Seventeenth Centuries", Isis, vol 94, nr. 2, juni 2003, s. 274-299. 
Tacklind J, Fink HA, Macdonald R, Rutks I, Wilt TJ, "Finasteride for benign prostatic hyperplasia", The Cochrane Database of Systematic Reviews, vol. 10, okt. 2010, s. 1465-1858.

Tansey, Elizabeth M., "The Physiological Tradition” Bynum, W. F. \& Porter, Roy (red.), Companion encyclopedia of the history of medicine. Vol. 1, Routledge, London, 1993.

Temkin, Owsei, "The Role of Surgery in the Rise of Modern Medical Thought", Bulletine of the History of Medicine, vol. 25, nr. 3, 1951, s. 248-259.

Valier, Helen, A History of Prostate Cancer. Cancer, Men and Medicine, Basingstoke: Palgrave Macmillan, 2016.

Verhoeven, Timothy, "Pathologizing Male Desire: Satyriasis, Masculinity, and Modern Civilization at the Fin de Siecle", Fournal of the History of Sexuality, vol. 24, nr. 1, januari 2015, s. 25-45.

Verhoeven, Timothy, "'Apostles of Continence': Doctors and the Doctrine of Sexual Necessity in Progressive-Era America”, Medical History, vol. 61, nr. 1, 2017, s. 89-106.

Wailoo, Keith, Drawing blood: technology and disease identity in twentieth-century America, Johns Hopkins University Press, London, 2000.

Warner, John Harley, Against the spirit of system: the French impulse in nineteenth-century American medicine, Princeton University Press, Princeton, NJ, 1998. 
Webb, Stephen, Clash of Symbols: A ride through the riches of glyphs, Springer International Publishing, 2018.

Weisz, George, "Making Medical History", Bulletin of the History of Medicine, vol. 80, nr. 1, våren 2006, s. 153-159 (Review)

Wilde, Sally, "See One, Do One, Modify One: Prostate Surgery in the 1930s.", Medical History, vol. 48, nr. 3, 2004, s. 351-366.

Winther Jørgensen, Marianne \& Phillips, Louise, Diskursanalys som teori och metod, Studentlitteratur, Lund, 2000.

Woolgar, Steve, "On the Alleged Distinction Between Discourse and Praxis", Social Studies of Science, vol. 16, nr. 2, 1986, s. 309-317.

\section{Internetkällor}

\section{Personer}

Jakob Ludvig (Jacques) Borelius

Riksarkivet https://sok.riksarkivet.se/sbl/mobil/Artikel/17973

[sidan besökt 2019-10-20]

\section{Leopold Ritter von Dittel}

http://www.jewishencyclopedia.com/articles/5232-dittel-leopold-ritter-von [sidan besökt 2019-09-23].

Jean Casimir Félix Guyon

Nordisk Familjebok, andra upplagan, 1909 http://runeberg.org/nfbj/0395.html [sidan besökt 2019-10-05] 
Jean Casimir Félix Guyon http://www.whonamedit.com/doctor.cfm/2943.html [sidan besökt 2019-10-20].

Charles B. Huggins

https://www.nobelprize.org/prizes/medicine/1966/huggins/facts/

[sidan besökt 2019-10-05].

Peter Axel Thorvald Iversen

http://denstoredanske.dk/Dansk_Biografisk_Leksikon/Sundhed/L\%C3\%A6ge /Axel_Iversen [sidan besökt 2019-09-23]

Pierre-Émile Launois

Pierre-Émile Launois http://www.whonamedit.com/doctor.cfm/777.html [sidan besökt 2019-10-16].

Fredrik Ramm

http://zinow.no/tngfiles1010/getperson.php?personID=I6183\&tree=tree 1zino w [sidan besökt 2016-10-20]

Alfred-Armand-Louis-Marie Velpeau

Nordisk Familjebok. Uggleupplagan, andra utgåvan

http://runeberg.org/nfck/0575.html, [sidan besökt 2019-10-20]

WorldCat Identities http://www.worldcat.org/identities/lccn-n86-844455/

[sidan besökt 2019-10-20]

Axel Richard Warholm

Svenskt Porträttgalleri http://runeberg.org/spg/13/0468.html

[sidan beskt 2019-10-20] 
Vem är det: Svensk biografisk handbok 1933

http://runeberg.org/vemardet/1933/0888.html [sidan besökt 2019-10-20]

\title{
Övrig information
}

\section{Adenoma}

https://www.lexico.com/en/definition/adenoma [sidan besökt 2019-10-25]

Akut psykos

http://www.lakartidningen.se/Klinik-och-vetenskap/Medicinens-

ABC/2013/04/ABC-om-Akut-psykos/ [sidan besökt 2019-10-05]

\section{Djurförsök i Sverige}

SOU 1998:75, Djurförsök https://lagen.nu/sou/1998:75\#S2

[Sidan besökt 2019-10-16]

\section{Myoma}

https://www.lexico.com/en/definition/myoma [sidan besökt 2019-10-25]

\author{
Skoptser \\ https://www-ne.se.e.bibl.liu.se/uppslagsverk/encyklopedi/l\%C3\%A5ng \\ /skoptser [sidan besökt 2019-10-17]
}

Wolffska gångar

https://www.ne.se [sidan besökt 2019-10-09] 


\section{FACULTY OF ARTS AND SCIENCES}

Linköping Studies in Arts and Sciences No. 774, 2019

Department of Thematic Studies - Technology and Social Change

Linköping University

SE-581 83 Linköping, Sweden

www.liu.se 